OCHRONA ZDROWIA

I GOSPODARKA 



\title{
OCHRONA ZDROWIA I GOSPODARKA
}

\author{
Pacjenci, świadczeniodawcy, \\ turystyka medyczna
}

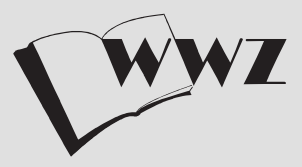

Wydawnictwo Naukowe Wydziału Zarządzania Uniwersytetu Warszawskiego

\author{
POD REDAKCJA \\ JóZEFa HaCZYŃSKIEGO,
RYCIA I ZOFII SKRZYPCZAK \\ JÓZEFA HACZYNSKIEGO,
KAZIMIERZA RYCIA I ZOFII SKRZYPCZAK
}

WARSZAWA 2018

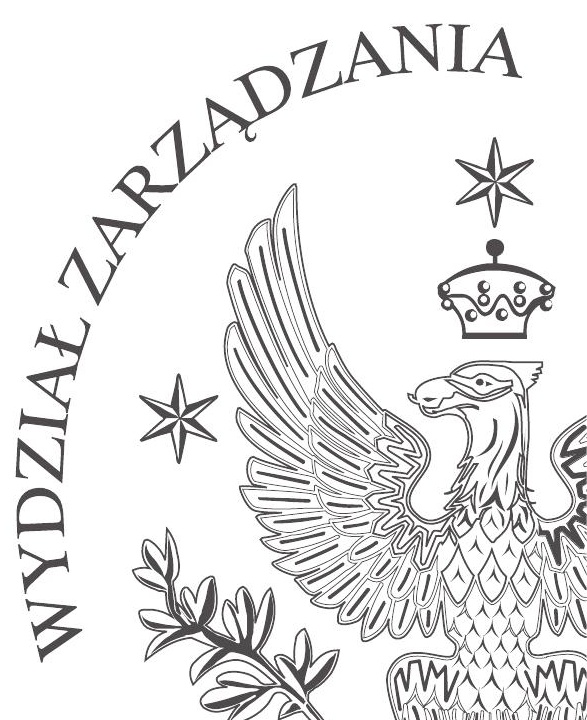


Recenzenci:

Rozdziały 1-9:

prof. dr hab. Ewelina Nojszewska (Szkoła Główna Handlowa)

Rozdział 10:

dr Monika Skorek (Uniwersytet Warszawski)

Redakcja: Teresa Pawlak-Lis

Projekt okładki: Agnieszka Miłaszewicz

(C) Copyright by Wydawnictwo Naukowe Wydziału Zarządzania Uniwersytetu Warszawskiego, Warszawa 2018

Wszelkie prawa zastrzeżone. Kopiowanie, przedrukowywanie i rozpowszechnianie całości lub fragmentów bez uzyskania pozwolenia zabronione.

ISBN: 978-83-66282-04-9

e-ISBN: 978-83-66282-07-0

DOI: 10.7172/978-83-66282-07-0.2019.wwz.2

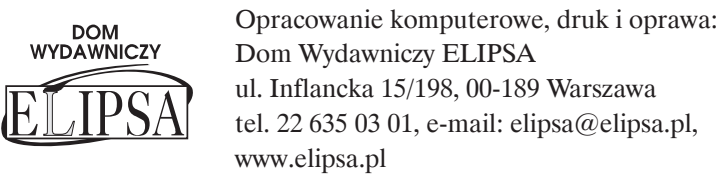




\section{Spis treści}

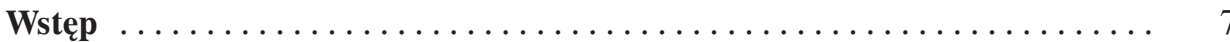

Jadwiga Suchecka, Maciej Jewczak

Starzejąca się Europa: nowe wyzwania dla Silver Economy . . . . . . . . 13

Józef Haczyński

Skutki starzenia się polskiego społeczeństwa $\ldots \ldots \ldots \ldots \ldots \ldots \ldots$

Sławomir Chomik

Wpływ transformacji cyfrowej na system ochrony zdrowia

i opieki społecznej pacjentów kardiologicznych w Polsce ......... 59

\section{Zofia Skrzypczak}

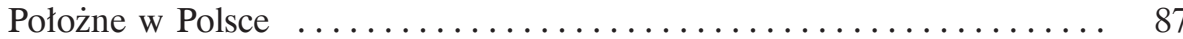

Natalia Kalinowska

Ochrona danych osobowych dotyczących zdrowia w świetle zmian

wprowadzanych przez rozporządzenie $2016 / 679$................ 109

\section{Karolina Elżbieta Stangret}

Historia turystyki medycznej. Krótki zarys od starożytności

do XIX wieku

\section{Dorota Matulka}

Turystyka medyczna - szansą na poprawę efektywności

w polskim systemie ochrony zdrowia

\section{Greta Kanownik}

Znaczenie rankingów w kształtowaniu konkurencyjności szpitali

- wyniki badań własnych . . . . . . . . . . . . . . . . . . . . 177

\section{Maciej Rogala}

Analiza strategii rozwojowych największych prywatnych sieci medycznych w Polsce. Podobieństwa i różnice oraz wyzwania na przyszłość

Karolina Hawryluk, Tomasz Hermanowski

Koszty reklamy leków OTC i suplementów diety w Polsce 



\section{Wstęp}

Na zmiany zachodzące $\mathrm{w}$ systemie ochrony zdrowia wywierają wpływ różne procesy wiążące się z demografią, zwłaszcza starzenie się społeczeństw, oraz wzrost zamożności społeczeństwa. Ochrona zdrowia ma więc za zadanie zarówno udzielenie pomocy, niezbędnej potrzebującym opieki medycznej - bez względu na ich sytuację materialną, lecz także - w coraz szerszym stopniu - powinna reagować na potrzeby pacjentów, którzy są znacznie bardziej wymagającymi klientami systemu opieki zdrowotnej, gotowymi finansować czy wspólfinansować zaspokojenie swoich potrzeb zdrowotnych.

Niniejsza monografia podejmuje problemy w czterech grupach tematycznych. Na początku są omawiane konsekwencje starzenia się społeczeństw, następnie - wybrane problemy zabezpieczenia zdrowotnego pacjentów, w dalszej kolejności - możliwości turystyki medycznej i na koniec - problemy konkurencyjności i rozwoju biznesu w dziedzinie ochrony zdrowia.

Cechą charakterystyczną współczesnych społeczeństw jest proces starzenia się globalnej populacji w tempie przyspieszonym. Nie są to zmiany nagłe, gdyż wielkość populacji osób starszych na świecie rośnie od stuleci. Potwierdzają to wyniki różnych badań ewolucji demograficznej, wskazując na zróżnicowanie przestrzenne okresów początkowych przejścia demograficznego. Jadwiga Suchecka i Maciej Jewczak zwracają uwagę na fakt, że współczesne podejście do starzenia się społeczeństw nie uwzględnia wyłącznie zmian w strukturze populacji, mających wpływ na budżet państwa, zasoby siły roboczej, konkurencyjność gospodarek i jakość życia, ale przede wszystkim na generowanie nowych ofert pracy i wzrostu gospodarczego (co jest określane również jako Silver Economy). Autorzy analizują zmiany demograficzne zachodzące w krajach Europy. Wskazują, że proponowane przez Unię Europejską inicjatywy polityczne dotyczące tzw. Srebrnej Gospodarki przejawiają się w takich działaniach, jak: rewitalizacja zasobów budynków z przeznaczeniem do samodzielnego życia osób starszych, rozwój turystyki dla seniorów poza sezonem, wprowadzenie systemów opieki długoterminowej (zwłaszcza zwrócenie uwagi 
na opiekę w miejscu zamieszkania osoby starszej), promowanie aktywnego stylu życia oraz starzenia się w zdrowiu, a także inwestycje w systemy i usługi ochrony socjalnej.

Problem starzenia się polskiego społeczeństwa - w aspekcie demograficznym, społeczno-ekonomicznym i medycznym - jest przedmiotem zainteresowania Józefa Haczyńskiego. Autor wskazuje, że zjawisko starzenia się ludności wpływa pośrednio na: poziom zamożności społeczeństwa, promowany model rodziny, aktywność zawodową kobiet, poziom opieki społecznej i ochrony zdrowia, wykształcenie ludności oraz politykę społeczną państwa. Proces starzenia się ma więc nie tylko wymiar demograficzny, ale także rodzi reperkusje ekonomiczne i społeczne. Proces ten generuje zmiany w strukturze konsumpcji, wywołuje wzrost zapotrzebowania na niektóre usługi, np. w dziedzinie ochrony zdrowia czy opieki społecznej, powoduje zmniejszenie aktywności zawodowej, zwiększenie wydatków na utrzymanie rosnącej populacji poprodukcyjnej, zmianę struktury siły roboczej, rodziny i gospodarstw domowych.

Sławomir Chomik dokonuje analizy wpływu innowacyjnych rozwiązań technologicznych na bieżące problemy demograficzne i wybrane parametry systemu ochrony zdrowia w Polsce, ze szczególnym uwzględnieniem pacjentów kardiologicznych (ze względu na wiodącą przyczynę śmiertelności w populacji). Nowe rozwiązania technologiczne, które pojawiają się w sektorze opieki zdrowotnej, są odpowiedzią na bieżące potrzeby. Zmiany demograficzne, starzenie się społeczeństw, w tym także samych lekarzy, związana z wiekiem większa zapadalność na choroby rosnącej populacji pacjentów sprawiają, że coraz trudniej będzie zapewnić indywidualną opiekę medyczną każdemu świadczeniobiorcy na satysfakcjonującym poziomie. Przy stale rosnących oczekiwaniach i kosztach systemów ochrony zdrowia, rozwiązaniem może być szersza i szybsza adaptacja nowych technologii, zarówno dla świadczeniodawców, jak i świadczeniobiorców.

Zofia Skrzypczak przedstawiła szczególną grupę pracowników sektora ochrony zdrowia, jaką są położne, zajmujące się zarówno edukacją i poradnictwem w zakresie planowania rodziny, jak i działaniami w zakresie promocji zdrowia i profilaktyki chorób położniczo-ginekologicznych. Jednak głównym zadaniem położnych jest opieka w okresie ciąży, porodu i połogu, opieka nad kobietą, noworodkiem i niemowlęciem do ukończenia drugiego miesiąca życia. Liczba położnych, organizacja i jakość ich pracy mają bezpośrednie przełożenie na prowadzenie ciąży oraz opiekę poporodową. Nie bez znaczenia jest również rola położnych $\mathrm{w}$ kształtowaniu prawidłowych postaw rodzicielskich, promowaniu karmienia piersią, poradnictwie z zakresie higieny, pielęgnacji i prawidłowego odżywiania w okresie ciąży i połogu. Przedmiotem opracowa- 
nia jest analiza zmian liczby położnych w Polsce w latach 2008-2016, prezentacja ich aktualnego stanu i porównanie z wybranymi krajami europejskimi.

Natalia Kalinowska omawia przewidywane konsekwencje stosowania od 25 maja 2018 roku rozporządzenia Parlamentu Europejskiego i Rady (UE) 2016/679 z 27 kwietnia 2016 roku w sprawie ochrony osób fizycznych w związku z przetwarzaniem danych osobowych i w sprawie swobodnego przepływu takich danych oraz uchylenia dyrektywy 95/46/WE. Rozporządzenie to wprowadza wiele zmian prawnych do przepisów o ochronie danych osobowych, w tym danych dotyczących zdrowia, które mają być odpowiedzią na postęp technologiczny i następujące zmiany społeczno-gospodarcze w Polsce. Rozporządzenie wprowadza definicję danych o stanie zdrowia, nowelizuje przepisy dotyczące przesłanek uchylających zakaz przetwarzania szczególnych kategorii danych, do których zaliczają się dane dotyczące zdrowia, zawiera także szereg regulacji, np. w zakresie oceny skutków dla ochrony danych czy powołania inspektora ochrony danych osobowych, odnoszących się do tej kategorii danych.

Karolina Elżbieta Stangret przedstawia historię turystyki medycznej od czasów starożytnych aż po XIX wiek. Na przestrzeni wieków zmieniała się ludzka wiedza na temat ciała, a wraz z nią wiedza medyczna. Jednak dostęp do lekarzy i środków uzdrawiających nie był powszechny ani osiągalny dla każdego, co często wiązało się z podróżowaniem w celu wyleczenia choroby lub poprawy stanu zdrowia. Przez długie stulecia leczono głównie ziołami oraz wodą termalną i mineralną. Autorka, prowadząc czytelnika przez kolejne epoki historyczne, pokazuje, gdzie udawano się leczyć i czym w takich miejscach leczono.

Dorota Matulka, kontynuując problematykę turystyki medycznej, stara się odpowiedzieć na pytanie: czy turystyka medyczna o charakterze wyjazdowym może przyczynić się do poprawy dostępności do usług medycznych w polskim systemie ochrony zdrowia? W pracy zamieszczono opinie mieszkańców Polski o skali trudności, związanych z otrzymaniem świadczeń medycznych, zaprezentowano także dostępne dla polskiego pacjenta rozwiązania prawne i organizacyjne, obejmujące możliwość wyjazdów na zagraniczne leczenie. Przedstawiono wiele danych dotyczących wpływu tych wyjazdów na oczekiwania w kolejce do specjalisty w Polsce oraz stan wiedzy pacjentów o możliwości leczenia za granicą.

Greta Kanownik zwraca uwagę na fakt, iż współcześnie rankingi stanowią element informacji dostępnej dla klientów oraz właścicieli firm o pozycji konkurencyjnej danego przedsiębiorstwa, branży czy kraju. Do korzyści wynikających z dokonywania porównań placówek można zaliczyć m.in.: pomoc w uzyskaniu większego stopnia satysfakcji klientów, umożliwienie identyfikacji deficytów, zrozumienie przez zarządzających powstałych deficytów i dążenie 
do doskonalenia procesów w organizacji w celu zwiększenia ich skuteczności i konkurencyjności, zwiększenie potrzeby wdrażania zmian, umożliwienie wyznaczania trendów oraz kierunków rozwoju. Rankingi mogą odgrywać także dużą rolę w kształtowaniu konkurencyjności na rynku medycznym. Dzięki nim pacjent ma możliwość uzyskania wiarygodnych informacji o szpitalu i dokonania świadomego, opartego na rzetelnej wiedzy wyboru szpitala, w którym chce być leczony. Autorka dokonała przeglądu rankingów szpitali na świecie oraz przedstawiła ranking „Bezpieczny Szpital”, przygotowany przez Centrum Monitorowania Jakości w Polsce. Jednocześnie pokazała mankamenty polskiego rankingu konkurencyjności szpitali oraz zaproponowała rekomendację pomiaru w oparciu o dokonaną analizę porównawczą rankingu polskiego $\mathrm{z}$ rankingiem stosowanym w Szwecji, podała także wyniki uzyskane z przeprowadzonego badania własnego.

Maciej Rogala poddał analizie podmioty prowadzące działalność biznesową w dziedzinie ochrony zdrowia. Przedstawił podobieństwa i różnice w strategii rozwoju trzech, działających nieprzerwanie od pierwszej połowy lat 90. XX wieku do dnia dzisiejszego, największych spółek medycznych (pod względem wysokości przychodów, liczby pacjentów i placówek na terenie całego kraju): Lux-Medu, Medicoveru i Enel-Medu. Istotnym elementem jego opracowania jest analiza wyzwań i szans płynących z otoczenia konkurencyjnego, które mogą doprowadzić do dalszego rozwoju tych spółek, jak również barier czy zagrożeń dla dalszego ich funkcjonowania w dotychczasowym zakresie (z uwagi na mogące wejść w życie zmiany o charakterze systemowym w sektorze ochrony zdrowia). Głównym celem pracy była analiza czynników, jakie zadecydowały o rozwoju i sukcesie na rynku usług medycznych trzech analizowanych spółek sieciowych, których głównym źródłem przychodów jest opieka abonamentowa dla firm i klientów indywidualnych. Przedmiotem badania były zasoby wewnętrzne, jakimi dysponują omawiane spółki, jak również uwarunkowania zewnętrzne płynące $\mathrm{z}$ otoczenia. Analizie poddano też podobieństwa i różnice w zakresie realizowanych strategii rynkowych - zarówno obieranych dotąd, jak i plany strategiczne na najbliższą przyszłość.

Karolina Hawryluk i Tomasz Hermanowski prezentują rozważania poświęcone kosztom reklamy leków bez recepty (OTC) oraz suplementów diety w Polsce. Wydatki na marketing firm farmaceutycznych reklamujących leki bez recepty i suplementy diety w ostatnich 10 latach wzrosły czterokrotnie, oba rynki warte są miliardy złotych. W 2015 roku firmy z sektora farmaceutycznego przeznaczyły na reklamę leków OTC 4,3 mld złotych (na reklamę telewizyjną - 2,82 mld złotych, a w stacjach radiowych $-1,12$ mld złotych). Niestety, nakłady finansowe na prace badawczo-rozwojowe w sektorze farmaceutycznym 
nie rosną w takim samym tempie, jak wydatki na reklamę. Opodatkowanie reklamy leków OTC i suplementów diety, wzorem podatku Garattiniego, który funkcjonuje we Włoszech od 2005 roku, umożliwiłoby przeznaczenie zgromadzonych środków na niezależne badania kliniczne nad lekami sierocymi, szerokie informowanie społeczeństwa o zasadach stosowania leków OTC oraz suplementów diety, zwłaszcza przyjmowanych w połączeniu z lekami przepisywanymi na receptę. 



\title{
Jadwiga Suchecka ${ }^{1}$ Maciej Jewczak ${ }^{2}$
}

\section{Starzejąca się Europa: nowe wyzwania dla Silver Economy}

\begin{abstract}
Streszczenie
Współczesne społeczeństwa charakteryzuje przyspieszony proces starzenia się ich populacji. Procesy te nie pojawiły się nagle, a wzrost wielkości populacji osób starszych potwierdzają wyniki badań ekspertów ds. zmian demograficznych. Długookresowe tendencje spadku płodności, postęp w medycynie i związana z nim poprawa stanu zdrowia, co w konsekwencji prowadzi do wzrostu długości życia, spowodowały zaburzenie proporcji oraz wzrost liczby osób starszych na całym świecie.

Wskazuje się, że aktualne zmiany demograficzne są wynikiem globalnego procesu przejścia demograficznego - od reprodukcji ludności typu tradycyjnego z wysoką płodnością i umieralnością do „reprodukcji nowoczesnej” o niskim natężeniu zgonów i niskiej płodności. Zachodzącym procesom towarzyszą również zmiany w innych dziedzinach funkcjonowania społeczeństwa - zmiany w profilach chorobowych, różnego rodzaju napięcia makroekonomiczne, postęp technologiczny, zmiana warunków pracy oraz norm społecznych. Wśród najważniejszych problemów dotyczących zdrowia i długowieczności wskazywana jest efektywność fiskalna systemów emerytalnych, zdrowotnych i ubezpieczeń społecznych, niezależnie od źródeł ich finansowania. Wyzwaniem dla trwałości systemów wsparcia dla osób starszych, staje się późniejsze wchodzenie na rynek pracy populacji młodszych, nabywanie wcześniejszych uprawnień emerytalnych, czy istotny trend wydłużania się dalszego życia w zdrowiu.
\end{abstract}

1 Jadwiga Suchecka - prof. dr hab., Katedra Badań Operacyjnych, Instytut Ekonomik Stosowanych i Informatyki, Wydział Ekonomiczno-Socjologiczny, Uniwersytet Lódzki, ul. Rewolucji 1905 r. nr 41/43, 90-214 Łódź, e-mail: jadwiga.suchecka@uni.lodz.pl; ORCID: 0000-0002-5686-8349.

2 Maciej Jewczak - dr, Katedra Badań Operacyjnych, Instytut Ekonomik Stosowanych i Informatyki, Wydział Ekonomiczno-Socjologiczny, Uniwersytet Lódzki, ul. Rewolucji 1905 r. nr 39, 90-214 Łódź, e-mail: maciej.jewczak@uni.lodz.pl; ORCID: 0000-0002-7837-3486. 
Jadwiga Suchecka, Maciej Jewczak

Podkreślające rangę i wagę problemu może być chociażby postanowienie Komisji Europejskiej ukierunkowania polityki na kolejne lata do podjęcia zintegrowanych działań w związku ze starzeniem się populacji. To podejście związane jest z kreowaniem aktywności ekonomicznej podmiotów gospodarczych znaną z teorii ekonomicznej, określanej terminem srebrnej gospodarki Silver Economy.

Celem proponowanego rozdziału jest przegląd dotychczasowych rozważań teoretycznych i empirycznych nt. starzejących się współczesnych społeczeństw, które będą musiały zmierzyć się z ryzykiem wysokich kosztów opieki zdrowotnej, ubezpieczenia społecznego i sprawiedliwością międzypokoleniową. Zagadnienia te już wywołują szeroką debatę publiczną zarówno w Europie, jak i w Ameryce Północnej. Szybkość starzenia się społeczeństwa skłania już dzisiaj niektóre rządy do zmian w dotychczasowej polityce demograficznej, a także, jak pokazują badania, zmusza do podjęcia działań zmierzających do ukierunkowania polityki społecznej (w tym polityki zdrowotnej) na zagwarantowanie właściwego zabezpieczenia zdrowotnego i socjalnego starzejącemu się społeczeństwu krajów europejskich.

Słowa kluczowe: starzenie się, Silver Economy, długość życia, polityka społeczna.

\title{
Ageing Europe: New Challenges for Silver Economy
}

\begin{abstract}
Societies today are characterised by accelerated population ageing. These processes did not appear suddenly, and a greater size of the elderly population is confirmed by the research results of experts in demographic change. Long-term trends of fertility decline, progress in medicine and related improvement of health, consequently leading to increased life expectancy, have disturbed the proportion and caused a rise in the number of elderly people around the world.

It is pointed out that current demographic changes are a result of the global demographic transition from traditional population reproduction with high fertility and mortality to "modern reproduction" with low mortality and fertility rates. The ongoing processes are also accompanied by changes in other areas of society functioning - changes in disease profiles, various types of macroeconomic tensions, technological progress, changes in working conditions and social norms. Among the most important problems concerning health and longevity, the fiscal efficiency of pension, health and social insurance systems is indicated, regardless of the sources of their financing. A challenge for the sustainability of support systems for older people lies in the younger population later entering the labour market, pension rights acquired earlier, or a significant trend of longer healthy life. What may highlight the importance and weight of the problem is, for example, the European Commission's decision to focus the policy for the coming years on integrated actions targeted at population ageing. This approach is associated with the creation of economic activity of economic operators known in the economic theory as "Silver Economy".

The aim of this chapter is to review the hitherto theoretical and empirical reflections on ageing of today's societies that will have to face the risk of high costs of healthcare, social insurance and intergenerational justice. These issues are already sparking off a widespread public debate in both Europe and North America. The pace of population ageing is already prompting some
\end{abstract}


governments to change their current demographic policy and - as research shows - also makes it necessary to take action in order to concentrate social policy (including health policy) on ensuring adequate health and social security for the ageing population in European countries.

Keywords: ageing, "Silver Economy", life expectancy, social policy.

\section{Wprowadzenie}

Cechą charakterystyczną współczesnych społeczeństw jest przyspieszony proces starzenia się globalnej populacji. Nie są to zmiany nagłe, gdyż wielkość populacji osób starszych na świecie rośnie od stuleci. Potwierdzają to wyniki badań ewolucji procesów ludnościowych, wskazujące na zróżnicowanie przestrzenne okresów początkowych przejścia demograficznego. Ten proces transformacji rozpoczął się w XVIII wieku w Europie Zachodniej i Północnej, zaś w drugiej połowie XIX wieku w Europie Południowej i Środkowej. Natomiast w krajach rozwijających się proces przejścia demograficznego rozpoczął się dopiero w drugiej połowie XX stulecia i obecnie wykazuje dość intensywny przebieg. Charakterystyczną tendencją przemian demograficznych w XXI wieku jest gwałtowne tempo starzenia się populacji o różnych poziomach rozwoju społeczno-gospodarczego. Długookresowe trendy obniżania płodności, poprawy stanu zdrowia i wzrostu długowieczności spowodowały zmiany proporcji, a tym samym wzrost liczby osób starszych na całym świecie. Spadek płodności i procesy urbanizacyjne stały się, m.in. dominującymi światowymi trendami demograficznymi w drugiej połowie XX wieku, podobnie jak - obserwowany w wielu krajach - dynamiczny wzrost, oczekiwanej w chwili urodzenia długości życia. Obecne zmiany demograficzne na świecie mają wpływ na kształtowanie się nowego porządku demograficznego w przyszłości. W literaturze przedmiotu wskazuje się, że aktualne zmiany demograficzne są wynikiem globalnego procesu przejścia, zgodnie z teorią przejścia demograficznego $^{3}$, od reprodukcji ludności typu tradycyjnego z wysoką płodnością i umieralnością do „reprodukcji nowoczesnej” o niskim natężeniu zgonów i niskiej płodności (Kotowska, Jóźwiak, 2012, s. 9).

Zjawisko to $\mathrm{w}$ teorii przejścia demograficznego jest określane mianem modernizacji ${ }^{4}$, która dokonała się pod wpływem zmian zachodzących w spo-

3 Teoria przejścia demograficznego jest ogólną teorią ludnościową, ze względu na jej aspekt historyczny i uniwersalny, wprowadzającą opis zmian reprodukcji, powodujących zmiany ludnościowe w większości społeczeństw.

4 Według Dirka J. van de Kaa sytuacja taka odpowiada modelowi drugiego przejścia demograficznego, w którym zostały wyspecyfikowane takie czynniki, jak: zmniejszenie dzietności, niski poziom umieralności, osiąganie przez rodziców wyższych dochodów z pracy, wyższego 
łeczeństwie w następujących sferach: ekonomicznej, społecznej, filozoficznej, kulturowej i demograficznej. Zmiany te następują pod wpływem systematycznego wzrostu wiedzy, industrializacji, urbanizacji, przejścia od gospodarki naturalnej w rolnictwie do przewagi produkcji rynkowej (Trzpiot, 2013, s. 52). Tym nieustającym zmianom w procesach demograficznych towarzyszą również zmiany w innych dziedzinach funkcjonowania społeczeństwa, a mianowicie zmiany w: profilach chorobowych, różnego rodzaju napięciach makroekonomicznych, pojawiających się nowych technologiach, zmieniających się warunkach pracy i normach społecznych. Powszechnie panuje pogląd, że wymienione czynniki są trudne do przewidywania, co wraz z ewoluującym kontekstem demograficznym może generować poważne problemy, które stają się problemami społeczno-ekonomicznymi zarówno obecnych, jak i przyszłych pokoleń. O wadze współczesnych problemów, wynikających ze zmian demograficznych, może świadczyć również jedno z wyzwań zaproponowanego na przyszłe lata programu Komisji Junckera ${ }^{5}$. W przedstawionych wytycznych zobowiązano Komisję Europejską m.in. do ukierunkowania polityki na kluczowe wyzwania stojące zarówno przed gospodarką europejską, jak i społeczeństwem oraz do podjęcia zintegrowanych działań w związku ze starzeniem się populacji.

Współczesne podejście do starzenia się społeczeństw nie ogranicza się tylko do analizowania zmian w strukturze populacji, mających wpływ na budżet państwa, zasoby siły roboczej, konkurencyjność gospodarek i jakość życia, lecz przede wszystkim zwraca uwage na możliwości generowania nowych ofert pracy i wzrostu gospodarczego. To nowe podejście do rozwiązania problemu starzejących się społeczeństw jest związane z kreowaniem aktywności ekonomicznej podmiotów gospodarczych, będących podstawą teorii ekonomicznej, określanej mianem Silver Economy ${ }^{6}$.

Ogólna definicja Silver Economy (Srebrna Gospodarka) orzeka, iż są to możliwości gospodarcze, wynikające z wydatków publicznych i konsumenckich, związanych ze starzeniem się społeczeństwa i specyficznymi potrzebami populacji powyżej 50. roku życia. W tej teorii przyjmuje się, że starzejąca się populacja posiada własne wzorce potrzeb, które mogą być przyporządkowane jednej z trzech podgrup osób starszych: populacji aktywnych (samodzielnych), częściowo aktywnych (wymagającej częściowej pomocy osób trzecich) oraz cał-

wykształcenia czy zadowolenia z życia i zwiększonej motywacji do podnoszenia poziomu życia rodzinnego (Kaa van de, 1987, s. 5).

515 lipca 2014 roku Parlament Europejski wybrał Jean-Claude'a Junckera na przewodniczącego KE, powierzając mu sformowanie nowej Komisji Europejskiej na kadencję 2014-2015.

6 W dokumencie Komisji Europejskiej Growing the Silver Economy in Europe (23.02.2015), przedstawiono przegląd istotnych inicjatyw Komisji Europejskiej dotyczących Silver Economy. 
kowicie niesprawnych (wymagających stałej pomocy i opieki osób trzecich). Ten trójstopniowy podział społeczeństwa starzejącego się powoduje, że zakres Srebrnej Gospodarki obejmuje dużą część ogólnej gospodarki konsumenckiej, ale ze znacznymi różnicami w priorytetach i wzorcach wydatków zarówno publicznych, jak i gospodarstw domowych.

Proponowane przez Unię Europejską inicjatywy polityczne dotyczące Srebrnej Gospodarki przejawiają się w takich działaniach, jak:

- rewitalizacja zasobów budynków z przeznaczeniem do samodzielnego życia osób starszych,

- rozwój turystyki dla seniorów poza sezonem, wprowadzenie zrównoważonych systemów opieki długoterminowej, szczególne zwrócenie uwagi na nieformalną opiekę w miejscu zamieszkania osoby starszej (zob. European Commission and Social Protection Committee, 2013),

- promowanie aktywnego stylu życia oraz starzenia się w zdrowiu,

- inwestycje społeczne w systemy i usługi ochrony socjalnej.

Jak wynika z dokumentu Komisji Europejskiej Growing the Silver Economy in Europe (2015, s. 5), podjęto również inicjatywy na rzecz aktywnego i zdrowego starzenia się (zob. Suchecka, Urbaniak, 2016, s. 159-163), które stanowią dla regionów europejskich priorytet inteligentnej specjalizacji i dodatkowo są uzupełniane inicjatywami krajowymi i sektorowymi.

Wdrażanie działań na rzecz aktywnego i zdrowego starzenia się oznacza realizację procesu optymalizacji szans na zdrowie z zagwarantowaniem uczestnictwa i bezpieczeństwa w celu poprawy jakości życia w miarę starzenia się kolejnych generacji społeczeństwa. Jak wynika z zaleceń $\mathrm{WHO}^{7}$, promowanie takich działań poprzez wdrażanie odpowiednich programów powinno umożliwiać osobom starszym wykorzystanie ich potencjału zarówno fizycznego, jak i społecznego, a także psychicznego do uczestnictwa w życiu społecznym w ostatnim cyklu życia ${ }^{8}$. Aktywność, w szerokim ujęciu jest współcześnie uważana za środek zapobiegający ograniczeniu sprawności umysłowej i fizycznej, z korzyścią dla jednostki i społeczeństwa (Rossi, Boccacin, Bramanti, Meda, 2014, s. 57).

7 Szersze omówienie wskazanych problemów znajduje się w opracowaniu World Health Organisation (2002).

8 Szersze omówienie koncepcji starzenia się aktywnego i w zdrowiu znajduje się w Decision No. 940/2011/UE of the European Parliament and of the Council of 14 September 2011 on the European Year for Active Ageing and Solidarity between Generations (2012), www. eur-lex.europa.eu (dostęp: 08.01.2018). 
Realizacja tych postulatów wymaga kształtowania odpowiedniej polityki ekonomiczno-społecznej i zdrowotnej w celu zagwarantowania sieci wsparcia, bezpieczeństwa oraz adekwatnej opieki zdrowotnej i socjalnej. Podejmowane działania wkomponowują się również w strategię Europa 2020, w której są zawarte nowe wyzwania dla starzejącego się społeczeństwa, dotyczące aktywnego i niezależnego życia przez dalsze lata, oraz przyczyniające się do dalszego rozwoju ekonomicznego i społecznego. Proponowana przez Komisję Europejską strategia wpisuje się także w jej koncepcję dotyczącą rozwoju europejskiej Srebrnej Gospodarki, odnoszącą się do kreowania elastycznych rynków pracy, związanych z nowymi ofertami pracy, wzrostu gospodarczego poprzez nowe inwestycje w usługi i sektor przemysłowy (A Common Narrative on the EU Silver Economy, 2015, s. 4).

Do sektorów, które mogą przynieść w przyszłości korzyści ze Srebrnej Gospodarki są zaliczane przez ekonomistów: rynki produktów kosmetycznych, turystyka senioralna, budownictwo inteligentnych domów, umożliwiających samodzielne funkcjonowanie osobom starszym, robotyka usługowa, ochrona zdrowia (w tym produkcja sprzętu medycznego, farmaceutyków, $e$-zdrowie) oraz usługi prozdrowotne typu wellness, a także bezpieczeństwo, kultura, edukacja i umiejętności, rozrywka, osobisty i autonomiczny transport, bankowość i odpowiednie produkty finansowe kierowane do seniorów9 9

Wiele publikowanych prognoz demograficznych (zob. The Ageing Report) dla krajów Unii Europejskiej wskazuje, że do 2060 roku wzrost wydatków publicznych związanych ze starzejącym się społeczeństwem będzie wzrastał średnio 4.1 punktów procentowych Produktu Krajowego Brutto, w tym: z powodu wzrostu wydatków, związanych z wypłatą emerytur (pierwszy filar) o 1.5 p.p. PKB, długoterminowej opieki zdrowotnej o 1.5 p.p. PKB i świadczeń opieki zdrowotnej 1.1 p.p. PKB.

Wzrost wydatków publicznych na opiekę długoterminową i świadczenia opieki zdrowotnej dla osób starszych wynika również ze wzrostu liczby osób przewlekle chorych. Na ten niekorzystny trend wskazują dane Eurostatu z 2012 roku (Eurostat, 2012), a mianowicie w krajach Europy jedna na dwie osoby (dotyczy to zarówno kobiet, jak i mężczyzn) w wieku powyżej 50. roku życia doświadcza choroby przewlekłej, a osoby starsze i przewlekle chore konsumują około $75 \%$ zasobów opieki zdrowotnej.

9 Bank of America Merrill Lynch Report 2014: The Silver Dollar - Longevity Revolution Primer, http://www.longfinance.net/images/reports/pdf/baml_silverdollar_2014.pdf (dostęp: 08.01.2018). 
Starzejąca się gwałtownie populacja Europy jest wynikiem zwiększonej długowieczności, w połączeniu z malejącą płodnością oraz postępem w medycynie.

\section{Zmiany demograficzne w Unii Europejskiej w perspektywie 2050 roku}

Zmieniające się struktury wieku populacji wymuszają na rządzących tworzenie lub reorganizację przyjętych polityk i programów. $\mathrm{Z}$ reguły realizacja programów, zaproponowanych przez różne organizacje (o zasięgu światowym, regionalnym lub krajowym), wywiera wpływ na wiele aspektów i dziedzin życia codziennego, zarówno jednostek jak i społeczeństwa. Na przykład w Japonii na początku 2000 roku parlament przegłosował obniżenie publicznych świadczeń emerytalnych i podniesienie wieku emerytalnego, co było poniekąd następstwem obniżek indywidualnych, prywatnych świadczeń emerytalnych ogłoszonych przez największych pracodawców w tym kraju. W całej Europie utrzymujące się wskaźniki płodności poniżej poziomu zastępowalności pokoleń wpłynęły na prognozy (a w niektórych społeczeństwach już obecnie obserwowalne) dotyczące spadków całkowitej wielkości populacji, co wywołało dyskusję nad restrykcyjnym nastawieniem względem polityki imigracyjnej w sytuacji prawdopodobnych niedoborów pracowników i szybkiego wzrostu liczby emerytów.

W niektórych krajach Afryki dziadkowie stali się głównymi opiekunami dużej liczby dzieci, które straciły rodziców w związku z epidemią HIV/AIDS. Natomiast w Stanach Zjednoczonych Ameryki Kongresowe Biuro Budżetowe przewiduje, że odsetek produktu krajowego brutto przeznaczonego na ubezpieczenia społeczne (Medicare i Medicaid) wzrośnie ponad dwukrotnie (do poziomu 17\%) do 2040 roku, przy czym największą dynamiką będą się charakteryzowały wydatki ponoszone na cele zdrowotne.

Analizując prognozy demograficzne (tabela 1 i 2), dotyczące liczby ludności świata i Europy do 2050 roku, opracowane przez ONZ na podstawie odpowiednich spisów ludności (rewizja 2015 roku oraz rewizja 2017 roku) ${ }^{10}$, można stwierdzić nierównomierny wzrost liczby ludności w poszczególnych obszarach geograficznych. W prognozowanym okresie liczba ludności świata wzrośnie o 18\%, Afryka podwoi liczbę swojej ludności, Europa natomiast odnotuje spadek liczby ludności o $16 \%$. Wzrostu liczby ludności należy również oczekiwać w obszarach Ameryki Łacińskiej, Ameryki Północnej oraz Oceanii.

10 Rewizje 2015 i 2017 roku opierają się na poprzednich wersjach, wprowadzając dodatkowe wyniki spisów powszechnych z 2010 roku, a także wyniki najnowszych badań demograficznych i zdrowotnych przeprowadzonych na całym świecie. 
Tabela 1. Ludność świata i głównych obszarów w perspektywie 2050 roku (w mln osób) (zgodnie z projekcją wariantu średniego)

\begin{tabular}{|l|r|r|r|}
\hline \multicolumn{1}{|c|}{ Glówne obszary } & $\mathbf{2 0 1 5}$ & $\mathbf{2 0 3 0}$ & $\mathbf{2 0 5 0}$ \\
\hline Świat & 7349 & 8501 & 9725 \\
\hline Afryka & 1186 & 1679 & 2478 \\
\hline Azja & 4393 & 4923 & 5267 \\
\hline Europa & 738 & 734 & 707 \\
\hline Ameryka Łacińska & 634 & 721 & 784 \\
\hline Ameryka Północna & 358 & 396 & 433 \\
\hline Oceania & 39 & 47 & 57 \\
\hline
\end{tabular}

Źródło: United Nations, Department of Economic and Social Affairs, Population Division (2015). World Population Prospects: The 2015 Revision. New York: United Nations, s. 1.

Podobna tendencje rysuje się $\mathrm{w}$ zaktualizowanej prognozie do 2100 roku (tabela 2), dotyczącej liczby ludności świata i głównych obszarów (rewizja z 2017 roku). W prezentowanych informacjach można zauważyć różnice w porównaniu z prognozą według rewizji z 2015 roku, wynikającą z wprowadzenia uaktualnień z najnowszych badań demograficznych i zdrowotnych prowadzonych na świecie. Jeśli w docelowym roku prognozy długookresowej do 2100 roku znacząco wzrośnie liczba ludności świata, to na to wpływ będzie miał prawie czterokrotny wzrost liczby ludności Afryki i nieznaczny wzrost liczby ludności Ameryki Północnej i Oceanii. Natomiast prognozowane jest zmniejszenie liczby ludności Ameryki Łacińskiej, Azji i Europy.

Tabela 2. Ludność świata i głównych obszarów w perspektywie 2100 roku (w mln osób) (zgodnie z projekcją wariantu średniego)

\begin{tabular}{|l|r|r|r|r|}
\hline \multicolumn{1}{|c|}{ Glówne obszary } & $\mathbf{2 0 1 7}$ & $\mathbf{2 0 3 0}$ & $\mathbf{2 0 5 0}$ & \multicolumn{1}{c|}{$\mathbf{2 1 0 0}$} \\
\hline Świat & 7550 & 8551 & 9772 & 11184 \\
\hline Afryka & 1256 & 1704 & 2528 & 4468 \\
\hline Azja & 4504 & 4947 & 5257 & 4780 \\
\hline Europa & 742 & 739 & 716 & 653 \\
\hline Ameryka Łacińska & 646 & 718 & 780 & 712 \\
\hline Ameryka Północna & 361 & 395 & 435 & 499 \\
\hline Oceania & 41 & 48 & 57 & 72 \\
\hline
\end{tabular}

Źródło: United Nations, Department of Economic and Social Affairs, Population Division (2017). World Population Prospects: The 2015 Revision. New York: United Nations, s. 1. 
Szczegółowe informacje dotyczące prognoz ludności Europy są prezentowane w tabeli 3. Wynika z nich, że począwszy od 2020 roku w kolejnych latach prognozy kurczy się liczebność populacji europejskiej, głównie za sprawą niekorzystnej ogólnej sytuacji demograficznej Europy Wschodniej i Europy Południowej. Niekorzystna jest również prognozowana sytuacja dla Polski, bowiem przy innych niezmienionych czynnikach, ekonomicznych i społecznych oraz kulturowych, jest prognozowany spadek liczby ludności w 2050 roku w stosunku do 2015 roku o około $15 \%$.

Tabela 3. Ogólna liczba ludności świata i Europy w perspektywie 2050 roku (w mln osób)

\begin{tabular}{|c|c|c|c|c|c|c|c|c|}
\hline Region/kraj & 2015 & 2020 & 2025 & 2030 & 2035 & 2040 & 2045 & 2050 \\
\hline Świat & 7349 & 7758 & 8142 & 8501 & 8839 & 9157 & 9454 & 9725 \\
\hline Europa & 738 & 740 & 738 & 734 & 728 & 721 & 714 & 707 \\
\hline Europa Wschodnia & 293 & 290 & 285 & 279 & 271 & 264 & 258 & 252 \\
\hline Polska & 39 & 38 & 38 & 37 & 36 & 35 & 34 & 33 \\
\hline Europa Północna & 102 & 105 & 108 & 110 & 112 & 114 & 116 & 118 \\
\hline Europa Południowa & 152 & 152 & 151 & 149 & 148 & 146 & 144 & 142 \\
\hline Europa Zachodnia & 191 & 193 & 195 & 196 & 196 & 197 & 196 & 196 \\
\hline
\end{tabular}

Źródło: United Nations, Department of Economic and Social Affairs, Population Division (2015), World Population Prospects: The 2015 Revision. New York: United Nations, s. 1.

W perspektywie 2050 roku liczba ludności w 28 krajach Europy wzrośnie zaledwie o 5,3\%, do czego może przyczynić się wzrost liczby ludności Wielkiej Brytanii, Francji i Włoch, wynikający również z nasilenia się pod koniec $\mathrm{XX}$ wieku procesów imigracyjnych ${ }^{11}$.

11 Na dzień 1 stycznia 2016 roku liczba osób zamieszkałych w UE-28 i będących obywatelami państw nieczłonkowskich wyniosła $20,7 \mathrm{mln}$, natomiast liczba mieszkańców UE-28 urodzonych poza UE sięgała 35,1 mln. Zob. http://ec.europa.eu/eurostat/statistics-explained/index.php/ Migration_and_migrant_population_statistics/pl (dostęp: 20.02.2018). 
Tabela 4. Ludność wybranych krajów UE do 2050 roku (mln osób)

\begin{tabular}{|l|r|r|r|r|r|}
\hline \multicolumn{1}{|c|}{ Kraje } & $\mathbf{2 0 1 5}$ & $\mathbf{2 0 2 0}$ & $\mathbf{2 0 3 0}$ & $\mathbf{2 0 4 0}$ & $\mathbf{2 0 5 0}$ \\
\hline UE (28) & 508,2 & 512,5 & 518,5 & 523,5 & 525,5 \\
\hline Niemcy & 80,7 & 80,6 & 79,8 & 77,8 & 74,7 \\
\hline Francja & 66,2 & 67,7 & 79,4 & 72,8 & 74,3 \\
\hline Wielka Brytania & 64,6 & 66,7 & 70,5 & 73,8 & 77,2 \\
\hline Włochy & 60,9 & 62,0 & 64,1 & 66,2 & 67,1 \\
\hline Hiszpania & 46.4 & 45.8 & 44.5 & 44.6 & 45.5 \\
\hline Polska & 38.5 & 38.4 & 37.5 & 36.2 & 34.8 \\
\hline
\end{tabular}

Źródło: EUROPOP (2013), http://ec.europa.eu/eurostat/statistics-explained/index.php/People_in_the EU_\%E2\%80\%93_population_projections\#Europop2013_.E2.80.94_population_projections (dostęp: 20.02.2018).

O niekorzystnej ogólnej sytuacji demograficznej w 28 krajach Unii Europejskiej świadczy również ich zróżnicowany udział w populacji europejskiej (rysunek 1). W docelowym roku prognozy wzrost udziałów ludności mogą odnotować Wielka Brytania, Francja i Włochy. Niestety, pozostałe kraje w przyszłości czeka niekorzystna sytuacja demograficzna, co może mieć również wpływ na pogorszenie stanu zdrowia populacji starszej, ze względu na obciążenia chorobami przewlekłymi oraz poprzez wzrost specjalistycznych usług opiekuńczych finansowanych z funduszy publicznych.

Rysunek 1. Udział liczby ludności wybranych krajów UE w populacji UE-28 ogółem

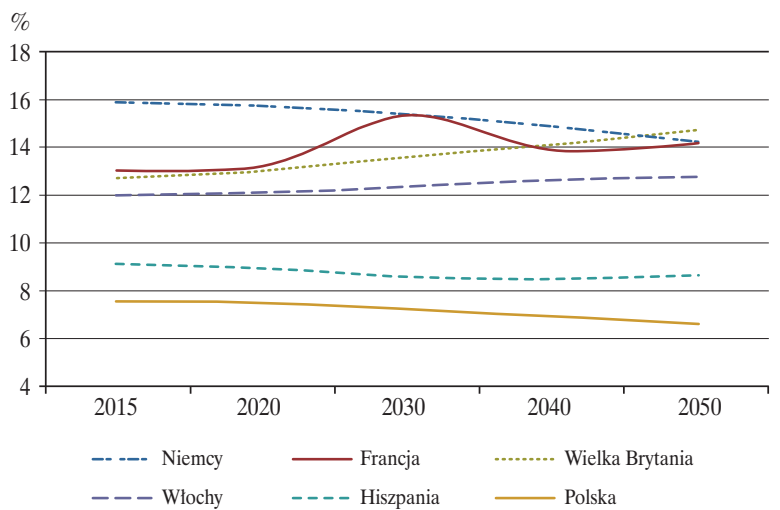

Źródło: opracowanie własne na podstawie: EUROPOP (2013). 
O strukturze demograficznej populacji według wieku informuje również syntetyczny miernik, którym jest mediana wieku (Maksimowicz, 1990, s. 266-289). W analizach porównawczych przekrojowo-czasowych (np. kraj, czas) mediana wieku jest stosowana jako miernik zaawansowania procesu starzenia się populacji (Abramowska-Kmon, 2011, s. 6). Mediana dzieli populację na dwie równe części osób „młodszych” i „starszych” względem wyznaczonego wieku.

$\mathrm{Z}$ prognoz demograficznych do 2050 roku prezentowanych przez ONZ wynika, iż najwyższą medianę wieku osiągnie ludność Europy Południowej wynoszącą 51,3 lat, również dla Polski miernik ten będzie posiadać wysoką wartość 51,8 lat. Szczegółowe dane dla wyróżnionych regionów Europy prezentowane są w tabeli 5 .

Tabela 5. Mediana wieku (w latach) ludności Europy w perspektywie 2050 roku

\begin{tabular}{|l|l|l|}
\hline \multicolumn{1}{|c|}{ Region/kraj } & $\mathbf{2 0 1 5}$ & $\mathbf{2 0 5 0}$ \\
\hline Świat & 29,6 & 36,1 \\
\hline Europa & 41,7 & 46,2 \\
\hline Europa Wschodnia & 39,6 & 43,9 \\
\hline Polska & 39,6 & 51,8 \\
\hline Europa Północna & 40,3 & 43,3 \\
\hline Europa Południowa & 43,9 & 51,3 \\
\hline Europa Zachodnia & 43,7 & 47,4 \\
\hline
\end{tabular}

Źródto: United Nations, Department of Economic and Social Affairs, Population Division (2017). World Population Prospects: The 2015 Revision. New York: United Nations, s. 1.

Z analizy danych liczbowych wynika, iż Europa w perspektywie długookresowej będzie zmierzała w kierunku zaawansowania procesu starzenia się. Jednym $\mathrm{z}$ najstarszych mierników zaawansowania procesu starzenia i najczęściej stosowanych jest miernik wyrażony jako udział osób starszych, tzn. w wieku 60 lat i więcej lub 65 lat i więcej, w ogólnej liczbie ludności danego regionu/kraju. 
Rysunek 2. Udział osób w wieku 65 i więcej lat w ogólnej populacji w 2016 roku

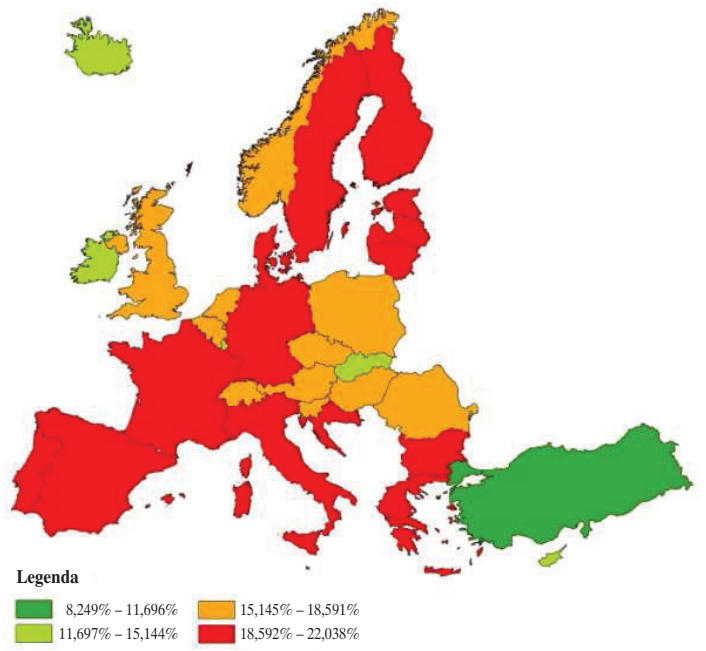

Źródło: opracowanie własne na podstawie danych Eurostatu.

Przyjmując definicję „populacji starej” zaproponowaną przez ONZ (1956) należy stwierdzić, że większość krajów europejskich wskazuje na globalny proces starzenia się populacji. Ten negatywny trend wzrostu stopnia zaawansowania procesu starzenia się ludności potwierdzają również wartości kolejnego miernika, którym jest współczynnik obciążenia osobami starszymi (współczynnik obciążenia demograficznego). Wyraża on liczbę osób w wieku 65 lat lub więcej przypadającą na 100 osób w wieku 15-64 lat.

Tabela 6. Współczynnik obciążenia demograficznego ludnością w wieku 65+

\begin{tabular}{|l|c|c|c|c|c|c|c|c|}
\hline \multicolumn{1}{|c|}{ Region/kraj } & $\mathbf{2 0 1 5}$ & $\mathbf{2 0 2 0}$ & $\mathbf{2 0 2 5}$ & $\mathbf{2 0 3 0}$ & $\mathbf{2 0 3 5}$ & $\mathbf{2 0 4 0}$ & $\mathbf{2 0 4 5}$ & $\mathbf{2 0 5 0}$ \\
\hline Świat & 12,6 & 14,3 & 16,1 & 18,1 & 20,3 & 22,3 & 23,8 & 25,6 \\
\hline Europa & 26,4 & 29,8 & 35,5 & 37,4 & 40,4 & 43,1 & 45,6 & 51,0 \\
\hline Europa Wschodnia & 21,1 & 25,2 & 28,9 & 31,4 & 31,8 & 33,5 & 36,3 & 40,2 \\
\hline Polska & 22,8 & 28,5 & 33,7 & 36,5 & 38,7 & 43,0 & 50,0 & 59,2 \\
\hline Europa Północna & 27,9 & 29,8 & 32,0 & 35,4 & 38,5 & 40,0 & 40,8 & 42,1 \\
\hline Europa Południowa & 30,8 & 33,9 & 37,8 & 43,2 & 48,1 & 50,0 & 50,5 & 51,6 \\
\hline Europa Zachodnia & 30,8 & 33,9 & 37,8 & 43,2 & 49,5 & 56,3 & 61,9 & 64,5 \\
\hline
\end{tabular}

Źródło: opracowanie własne na podstawie: EUROPOP (2013). 
W perspektywie do 2050 roku poszczególne regiony europejskie odnotują znaczący wzrost udziału osób w wieku 65 lat lub więcej w ogólnej liczbie ludności. Najwyższe wartości wskaźników są prognozowane dla Europy Zachodniej (prawie dwukrotny wzrost w stosunku do 2015 roku) i Europy Południowej - 51,8. Tak więc wszystkie regiony europejskie znajdą się w okresie starości demograficznej, której jedną z przyczyn jest malejąca liczebność populacji najmłodszej - w wieku 0-9 lat lub 9-14 lat, a udział tej grupy w ogólnej liczebności jest również określany indeksem starości demograficznej. Rozkład przestrzenny wartości udziału osób w wieku do 15 lat w ogólnej liczbie ludności w bazowym 2016 roku analizy jest prezentowany na rysunku 3 , na którym wyraźnie zaznacza się grupa państw o stosunkowo niskich wartościach tego indeksu. Porównanie wartości udziałów najstarszych i najmłodszych grup wiekowych wyraźnie wskazuje na wzrost stopnia zaawansowania procesu starzenia się ludności (według prognoz i szacunków) w regionach europejskich i może mieć różne natężenia w perspektywie długookresowej. Według Cezarego Żołędowskiego (2012, s. 31) starzenie się ludności jest bezpośrednią konsekwencją obniżania się poziomu urodzeń, spadku umieralności w najstarszych grupach wiekowych, a także salda migracji.

Rysunek 3. Udział osób w wieku do 15 lat w ogólnej populacji w 2016 roku

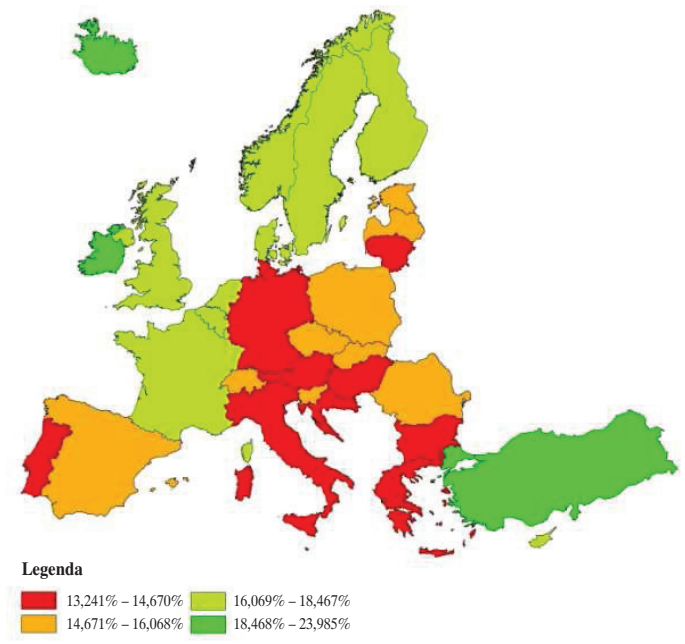

Źródło: opracowanie własne na podstawie danych Eurostatu.

Zjawiska te charakteryzowały procesy demograficzne, których przebieg był uwarunkowany również silnymi procesami urbanizacyjnymi i zmieniającymi się normami społeczno-ekonomicznymi. Prezentowana sytuacja odpowiada etapo- 
wi przejścia demograficznego, określanego mianem reprodukcji nowoczesnej, który obecnie ma charakter ogólnoświatowy.

$\mathrm{Z}$ prezentowanych danych wynika, iż w prognozowanym okresie proces odtwarzania pokoleń będzie kształtował się poniżej prostej ich zastępowalności ${ }^{12}$. Natomiast w 2000 roku dwa obszary europejskie: Europa Wschodnia i Europa Południowa charakteryzowały się bardzo niską płodnością. Prognozy długookresowe do 2100 roku również wskazują na niekorzystną sytuację demograficzną, pomimo wzrostu wartości prognozowanych wskaźników płodności nie przekroczą one 2,2 urodzonych dzieci przez kobietę $\mathrm{w}$ wieku rozrodczym, gwarantujących reprodukcję rozszerzoną. Najniższe wskaźniki dzietności są przewidywane dla Europy Południowej.

Tabela 7. Współczynniki płodności dla Europy i regionów europejskich (liczba urodzeń żywych na kobietę) w latach 1950-2100

\begin{tabular}{|l|c|c|c|c|c|c|c|c|c|}
\hline Europa i regiony & $\mathbf{1 9 5 0}$ & $\mathbf{2 0 0 0}$ & $\mathbf{2 0 1 0}$ & $\mathbf{2 0 1 5}$ & $\mathbf{2 0 2 0}$ & $\mathbf{2 0 3 0}$ & $\mathbf{2 0 5 0}$ & $\mathbf{2 0 7 5}$ & $\mathbf{2 1 0 0}$ \\
\hline Świat & 4,96 & 2,75 & 2,52 & 2,49 & 2,47 & 2,39 & 2,24 & 2,28 & 1,97 \\
\hline Europa & 2,66 & 1,43 & 1,55 & 1,60 & 1,62 & 1,60 & 1,78 & 1,82 & 1,84 \\
\hline Europa Wschodnia & 2,92 & 1,30 & 1,42 & 1,57 & 1,61 & 1,68 & 1,80 & 1,84 & 1,86 \\
\hline Europa Północna & 2,32 & 1,70 & 1,85 & 1,85 & 1,85 & 1,86 & 1,86 & 1,87 & 1,87 \\
\hline Europa Południowa & 2,68 & 1,34 & 1,44 & 1,42 & 1,45 & 1,53 & 1,65 & 1,73 & 1,77 \\
\hline Europa Zachodnia & 2,39 & 1,52 & 1,64 & 1,67 & 1,69 & 1,74 & 1,78 & 1,82 & 1,84 \\
\hline
\end{tabular}

Źródło: United Nations, Department of Economic and Social Affairs, Population Division (2017). World Population Prospects: The 2017 Revision. New York: United Nations, s. 1.

Podsumowując rozważania dotyczące obecnych i prognozowanych przekształceń struktur wieku ludności oraz liczby ludności starego kontynentu, „nowa demografia Europy może być scharakteryzowana trzema »naj«: najniższa w historii i w porównaniu z innymi regionami świata płodność, najdłuższe trwanie życia i największa liczba osób w wieku powyżej 80 lat, najwyższa intensywność migracji” (Kotowska, Jóźwiak, 2012, s. 12). Wraz ze zmianami demograficznymi obserwuje się zmiany w zdrowiu publicznym, jakości życia oraz rosnące zapotrzebowanie na zasoby zarówno społeczne, jak i ekonomiczne. Współczesne społeczeństwa są zobowiązane do świadczenia usług zdrowot-

12 O bardzo niskiej płodności świadczy wartość przekrojowego współczynnika dzietności ogólnej (TFR) nie przekracza 1,35 na kobietę w wieku rozrodczym, reprodukcję rozszerzoną gwarantującą zastępowalność pokoleń charakteryzuje wartość miernika powyżej 2,2 (por. Kotowska, Jóźwiak, 2012, s. 10). 
nych i zabezpieczenia społecznego swoim obywatelom (Trzpiot, 2013, s. 51). Dotyczy to również świadczenia usług społecznych, gospodarczych i zdrowotnych, w celu zapewnienia optymalnego wsparcia osobom starszym, aczkolwiek kierunki i sposoby podnoszenia statusu zdrowotnego, a także dobrobytu społecznego i ekonomicznego populacji starszych wykazują zróżnicowanie w międzynarodowych porównaniach.

Wśród najważniejszych problemów politycznych dotyczących zdrowia i długowieczności są wskazywane przyszłe możliwości fiskalne systemów emerytalnych, zdrowotnych i ubezpieczeń społecznych, zarówno finansowanych ze środków publicznych, jak i ze źródeł prywatnych. Swoistym wyzwaniem dla trwałości systemów zaprojektowanych w celu wspierania osób starszych, staje się późniejsze wchodzenia na rynek pracy populacji młodych, nabywanie wcześniejszych uprawnień emerytalnych, czy zauważalny trend w kierunku wydłużania się przeciętnego dalszego życia.

Wiele aktywności dotyczących funkcjonowania jednostki, tj. uczestnictwo w rynku pracy, inwestowanie, czy zachowania związane z oszczędzaniem na przyszłe wydatki związane ze zdrowiem, również i świadczenie usług zdrowotnych, są zjawiskami złożonymi. Zjawiska te są ze sobą powiązane zarówno na poziomie indywidualnym, jak i ogólnospołecznym (Martin, Preston, red., 1994, s. 50-101; Smith, 1999, s. 145-166),

\section{Zdrowie publiczne w starzejącej się Europie}

Stan zdrowia populacji jest jednym z najważniejszych wskaźników dobrobytu, tym samym wymaga znacznej części wydatków społecznych przeznaczanych na usługi zdrowotne i społeczne dla osób starszych. Przyjmowane polityki i programy, które mogą wydawać się przeznaczone na opiekę zdrowotną i usługi zdrowotne dla osób starszych, często mają ważne implikacje i złożone interakcje $\mathrm{z}$ innymi sektorami gospodarki. Te implikacje można poddać w sposób uogólniony pewnej analizie (tabela 8).

Prezentowane wyniki badań nad możliwościami kreowania odpowiedniej polityki w zakresie działalności różnych podmiotów gospodarczych, ukierunkowanych na subpopulację osób w starszym wieku, są zbieżne z założeniami Silver Economy. Należy jednak podkreślić, że największe znaczenie dla kreowania odpowiednich polityk ekonomicznych, społecznych czy też zdrowia będzie odgrywał proces starzenia się społeczeństw i gwałtowny wzrost ogólnych wydatków, przeznaczonych na opiekę zdrowotną.

Dane statystyczne Banku Światowego dowodzą, że na przestrzeni ostatnich lat zwiększa się udział wydatków przeznaczanych na sektor opieki zdrowotnej 

(rysunek 4). Polska w tym aspekcie mocno odbiega od poziomów wydatków
charakterystycznych dla krajów Unii Europejskiej czy członków OECD.

Tabela 8. Relacja programów i polityk sektora publicznego z usługami opieki zdrowotnej dla osób starszych

\begin{tabular}{|l|l|}
\hline $\begin{array}{c}\text { Wyróżnione obszary } \\
\text { polityk sektora } \\
\text { publicznego }\end{array}$ & \multicolumn{1}{c|}{ Oddziaływania programów i polityk } \\
\hline \multicolumn{1}{|c|}{ Mieszkalnictwo } & $\begin{array}{l}\text { Zapewnienie lokali odpowiedniej jakości, zarówno tych dla potrzeb } \\
\text { społeczeństwa, jak i dla funkcjonowania instytucji w celu utrzymania } \\
\text { odpowiedniego poziomu zdrowia. }\end{array}$ \\
\cline { 2 - 3 } & Dostosowanie lokali do potrzeb niepełnosprawnych starszych osób. \\
\hline \multirow{2}{*}{$\begin{array}{l}\text { Polityka w zakresie } \\
\text { zdrowia publicznego }\end{array}$} & $\begin{array}{l}\text { Tworzenie programów profilaktyki i promocji zdrowia, które dotyczą osób } \\
\text { starszych. }\end{array}$ \\
\hline \multirow{2}{*}{ Edukacja } & $\begin{array}{l}\text { Szkolenie pracowników różnego szczebla służby zdrowia i pracowników } \\
\text { pomocniczych dotyczące problemów osób starszych. }\end{array}$ \\
\hline \multirow{2}{*}{ Przemyst/maszyny } & $\begin{array}{l}\text { Wykorzystanie zaawansowanych urządzeń mechanicznych i elektronicznych } \\
\text { w leczeniu i rehabilitacji osób starszych. }\end{array}$ \\
\hline \multirow{2}{*}{ Przestrzeń miejska } & $\begin{array}{l}\text { Lokalizacja mieszkań dla osób starszych, dająca optymalny dostęp do usług } \\
\text { zdrowotnych, rekreacyjnych, socjalnych itp. }\end{array}$ \\
\cline { 2 - 3 } Transport & Możliwości wykorzystania kompetencji i zaangażowania osób starszych. \\
\hline $\begin{array}{l}\text { Zapewnienie transportu publicznego i ułatwienie transportu } \\
\text { zindywidualizowanego w celu zwiększenia mobilności społecznej. }\end{array}$ \\
\hline
\end{tabular}

Źródło: National Research Council (2001). Preparing for an Aging World: The Case for Cross-National Research. Panel on a Research Agenda and New Data for an Aging World. National Academy Press, s. 202.

Rysunek 4. Wydatki na opiekę zdrowotną, jako \% PKB

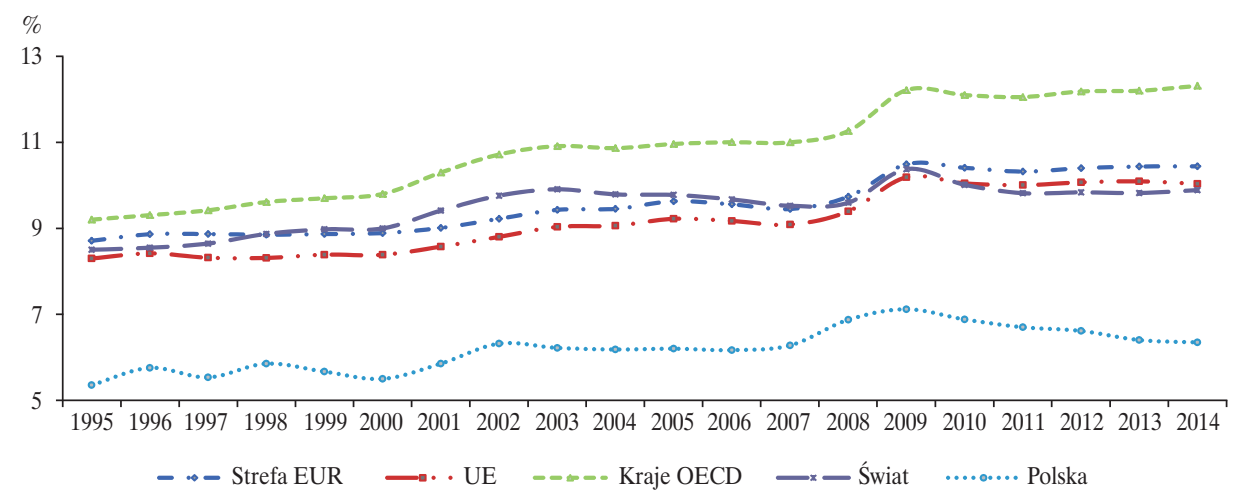

Źródło: opracowanie własne na podstawie danych The World Bank. 
Nie należy zapominać, że usługi zdrowotne dedykowane osobom starszym różnią się pod wieloma względami od świadczeń przewidzianych innym subpopulacją. Należy tu wskazać: większe zapotrzebowanie na zasoby, przenikanie się profesjonalnych usług zdrowotnych ze świadczeniami społecznymi, częstsze występowanie dylematów etycznych, wyższą częstość występowania upośledzeń fizycznych i umysłowych, mniejszą restrykcyjność przy określaniu efektywności interwencji profilaktycznych i zdrowotnych.

Postęp w medycynie, jaki dokonał się w ostatnich latach XX wieku, wzrost jakości świadczonych usług zdrowotnych oraz wzrost dbałości o zdrowie i aktywne starzenie się przyczyniło się również do wzrostu liczby lat przeżycia w zdrowiu po ukończeniu 65 roku życia zarówno wśród kobiet, jak i mężczyzn. Tendencja ta była charakterystyczna dla większości krajów europejskich w latach 2006-2015 (rysunki 5 i 6) i może dalej wykazywać tendencję wzrostową. Wysoką dynamikę zmiany przewidywanej długości lat w zdrowiu po osiągnięciu 65 roku życia wśród kobiet wykazały: Słowacja $(+61,9 \%)$, Bułgaria $(+46,75 \%)$ oraz Cypr $(+44,95 \%)$. Dla Polski wskaźnik ten wyniósł $+38,37 \%$. Odmienna sytuacja charakteryzuje starsze kobiety we Włoszech, gdzie przewidywana długość lat w zdrowiu po osiągnięciu 65 roku wynosi $(-1,38 \%)$. Porównując analogiczne wskaźniki dla mężczyzn w wieku 65 lat, wysoką dynamikę wzrostu wykazały: Słowacja $(+41,79 \%)$, Estonia $(+33,70 \%)$ oraz Finlandia $(+28,80 \%)$.

Rysunek 5. Stopa wzrostu długości życia w zdrowiu dla kobiet w wieku 65 i więcej w latach 2006-2015

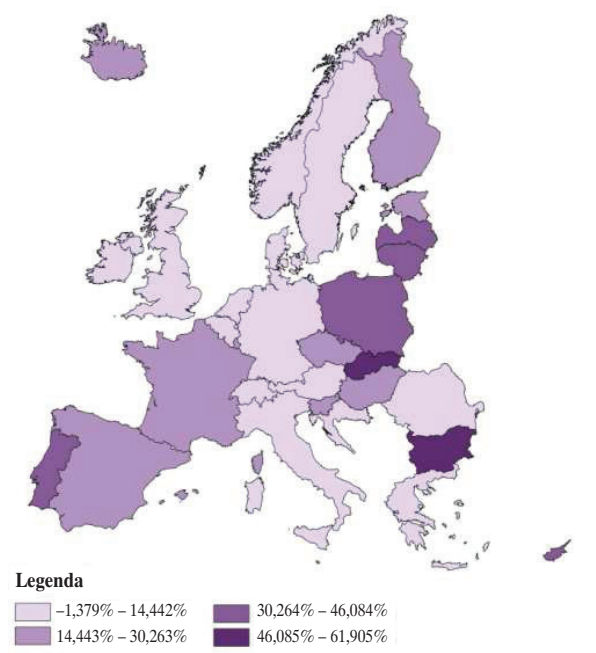

Źródło: opracowanie własne na podstawie danych Eurostatu. 
Rysunek 6. Stopa wzrostu długości życia w zdrowiu dla mężczyzn w wieku 65 i więcej w latach 2006-2015

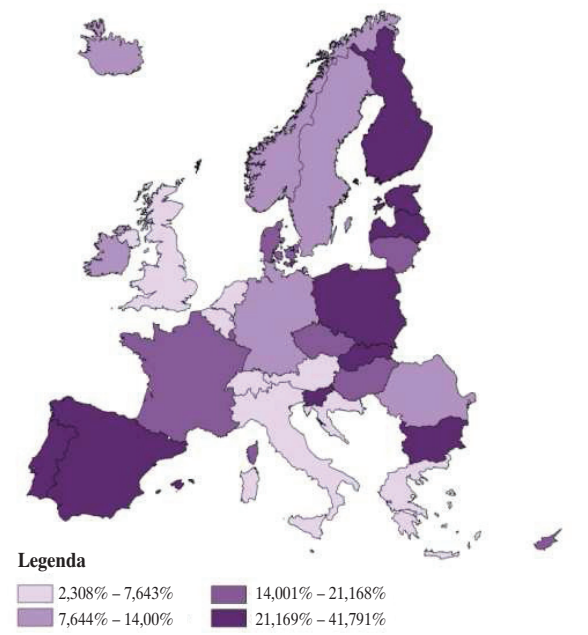

Źródło: opracowanie własne na podstawie danych Eurostatu.

Prognozowana liczba lat życia w zdrowiu dla seniorów w wieku 65 również wykazuje dość duże zróżnicowanie (tabela 9). Dla wybranych krajów europejskich można mówić o ponad dwukrotnie dłuższym życiu w zdrowiu zarówno kobiet, jak i mężczyzn w takich krajach jak Islandia i Szwecja, w porównaniu do Chorwacji czy Litwy. Polsce, pomimo wysokiej dynamiki wzrostu przewidywanej liczby lat w zdrowiu, również daleko jeszcze do poziomów krajów wysoko rozwiniętych; dla kobiet w 2015 roku wskaźnik wynosił 11,9 lat, a dla mężczyzn 10,1 lat.

Tabela 9. Przewidywane lata życia w zdrowiu w wieku 65 lat w 2015 roku dla wybranych krajów o najniższej i najwyższej liczbie według płci

\begin{tabular}{|l|c|l|c|}
\hline \multicolumn{2}{|c|}{ Kobiety } & \multicolumn{2}{c|}{ Mężczyźni } \\
\hline Chorwacja & 8,9 & Chorwacja & 8,1 \\
\hline Litwa & 9,8 & Lotwa & 8,6 \\
\hline Węgry & 10,1 & Litwa & 8,6 \\
\hline Islandia & 19,4 & Irlandia & 17,1 \\
\hline Norwegia & 19,7 & Szwecja & 17,9 \\
\hline Szwecja & 19,9 & Islandia & 18,1 \\
\hline
\end{tabular}

Źródło: opracowanie własne na podstawie danych Eurostatu. 
Do oceny stanu zdrowia publicznego często jest wykorzystywana samoocena dokonana na podstawie odpowiednio sformułowanych kwestionariuszy. Jak wynika z prezentowanych na rysunku 7 mapach, seniorzy zamieszkujący w krajach europejskich różnie oceniają swój stan zdrowia.

Rysunek 7. Samoocena stanu zdrowia ludności w wieku 65 + w UE w 2015 roku
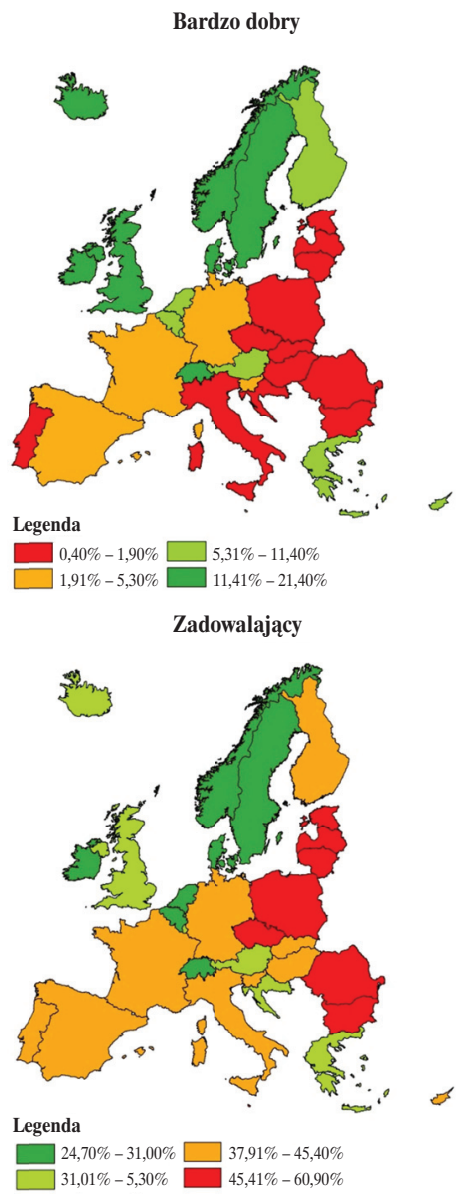

Dobry

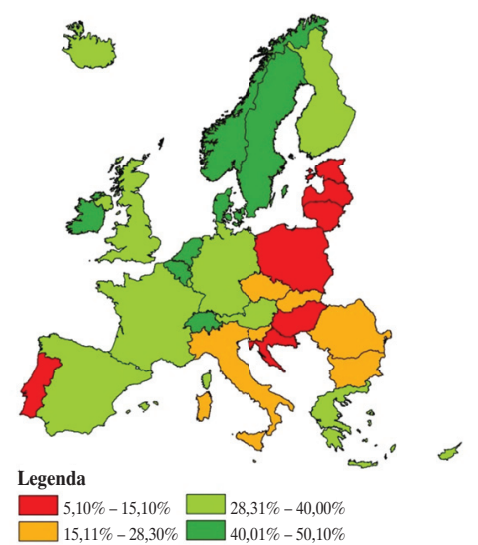

Zly i bardzo zły

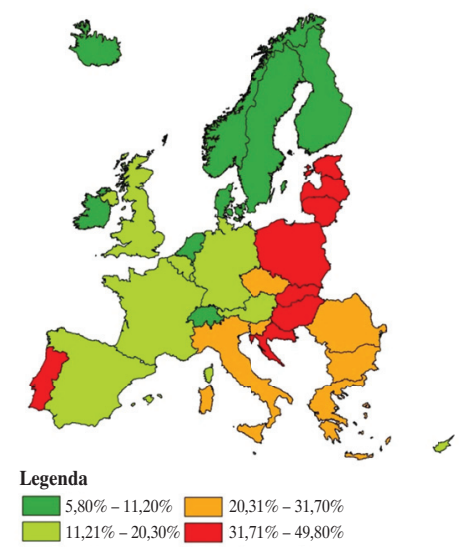

Źródło: opracowanie własne na podstawie danych Eurostatu.

W większości przypadków opinie te wskazują na zadowalający stan zdrowia, rzadziej osoby w wieku $65+$ określają swój stan zdrowia jako dobry, a bardzo dobrym zdrowiem w 2015 roku charakteryzowali się nieliczni. Natomiast na 
zły i bardzo zły stan zdrowia wskazywali starsi mieszkańcy Europy Środkowej i Wschodniej, stanowiąc od 31,7\% do 49,8\% badanej populacji respondentów.

$\mathrm{Na}$ niską samoocenę zdrowia starszej ludności krajów Unii Europejskiej może mieć wpływ stopień niezaspokojenia potrzeb zdrowotnych. $\mathrm{Z}$ prezentowanych danych statystycznych (tabela 10) wynika, iż na zły i bardzo zły stan zdrowia wskazują starsi mieszkańcy krajów europejskich, w których odnotowano niski i bardzo niski poziom zaspokojenia potrzeb zdrowotnych.

Tabela 10. Poziom niezaspokojonych potrzeb zdrowotnych wśród osób w wieku $65+$ w 2015 roku

\begin{tabular}{|l|l|}
\hline \multicolumn{1}{|c|}{$\begin{array}{c}\text { Poziom } \\
\text { niezaspokojenia }\end{array}$} & \multicolumn{1}{c|}{ Kraje* $^{*}$} \\
\hline $0-10 \%$ & $\begin{array}{l}\text { Holandia, Austria, Słowenia, Niemcy, Cypr, Norwegia, Szwajcaria, } \\
\text { Hiszpania, Luksemburg, Francja, Belgia, Malta, Irlandia, Islandia, Czechy, } \\
\text { Dania, Szwecja, Wielka Brytania, Portugalia, Węgry }\end{array}$ \\
\hline $10-20 \%$ & Chorwacja, Słowacja, Litwa, Bułgaria, Finlandia, Włochy \\
\hline $20-30 \%$ & Serbia, Polska, Łotwa \\
\hline $30-40 \%$ & Estonia, Grecja \\
\hline pow. 50\% & Rumunia \\
\hline
\end{tabular}

* Kolejność krajów odzwierciedla wzrost poziomu niezaspokojenia potrzeb.

Źródło: opracowanie własne na podstawie danych Eurostatu.

Podsumowując dotychczasowe rozważania można sformułować wniosek, że dzisiejsze szybko starzejące się społeczeństwa nieuchronnie staną przed ryzykiem wysokich kosztów opieki zdrowotnej, ubezpieczenia społecznego i sprawiedliwością międzypokoleniową, które wywołały debatę publiczną zarówno w Europie, jak i w Ameryce Północnej (Kinsell, Gist, 1995). Szybkość starzenia się społeczeństwa może nawet skłonić rządy do ponownego przemyślenia ogólnej polityki demograficznej, jak to miało miejsce w Singapurze (Phillips, Bartlett, 1995, s. 349-356), ale także podjąć działania, zmierzające do ukierunkowania polityki społecznej, w tym polityki zdrowotnej na zagwarantowanie właściwej opieki zdrowotnej i socjalnej starzejącemu się społeczeństwu krajów europejskich.

\section{Podsumowanie}

Współczesne problemy starzejącej się populacji europejskiej w przyspieszonym i zróżnicowanym tempie między regionami powoduje zintensyfikowanie 
działań w celu ograniczenia niekorzystnych procesów zagrażających zrównoważonemu rozwojowi poszczególnych krajów Unii Europejskiej. W zakresie zdrowia i Srebrnej Gospodarki Komisja Europejska podejmowała lub podejmuje nowe inicjatywy, kierowane do populacji osób starszych. Można tutaj wymienić Program Zdrowie UE 2008-2013 - inwestowanie w zdrowie i rozwiązywanie problemu starzejącego się społeczeństwa, który obejmował siedem różnych programów już wdrożonych lub sukcesywnie wdrażanych w kolejnych latach, takich jak np.: promocja aktywności fizycznej dla osób starszych (EUNAAPA), promocja wiedzy o potencjalnie skutecznych i wydajnych modelach zintegrowanej opieki dla obywateli europejskich, cierpiących na wiele chorób przewlekłych (ICARE4U), poprawa efektywności kosztowej interwencji zdrowotnych ukierunkowana na wielochorobowość i wielolekowość osób starszych (MPI_AGE) ${ }^{13}$.

Należy również wskazać inne działania ukierunkowane na starzejące się społeczeństwo. W propozycjach Komisji Europejskiej wskazano również na: konieczność tworzenia przyjaznego dla wieku środowiska, wspólną inicjatywę programową „zdrowa dieta dla zdrowego życia”, ukierunkowaną na określenie wyznaczników diety i aktywności fizycznej, diety i produkcji żywności oraz wskazaniu chorób przewlekłych związanych z dietą.

O powadze problemu starzejącego się społeczeństwa mogą również świadczyć badania naukowe finansowane w ramach programu Horyzont 2020 (Horizon 2020 Societal Challenge) dotyczące np.: zdrowia, zmian demograficznych i dobrobytu, czy też innowacyjnych inicjatyw medycznych, związanych z partnerstwem publiczno-prywatnym z Europejską Federacją Przemysłu Farmaceutycznego (European Federation of Pharmaceutical Industries and Associations - EFPIA).

Wszelkie działania naukowe, innowacje i podejmowane inicjatywy są podporządkowane trzem zasadniczym wyzwaniom: lepsza jakość życia obywateli jako pacjentów, opiekunów i pracowników, poprawa stabilności zdrowia i systemów opieki zdrowotnej, stymulowanie nowych miejsc pracy i wzrostu gospodarczego. Ponadto, należałoby zwrócić uwagę na personalizowanie zdrowia i opieki, wzmocnienie sektora ochrony zdrowia oraz stymulowanie rynku innowacji przy silnym wsparciu dla małych i średnich przedsiębiorstw ${ }^{14}$.

Z prezentowanych rozważań wynika, że wszelkie działania powiązane z problemami starzenia się społeczeństw powinny być związane ze Srebrna Gospodarka, poprzez wzrost wiedzy na temat biologicznego procesu starzenia

13 Szczegółowe informacje dotyczące inicjatyw europejskich zawiera ANNEX II: Groving the European Silver Economy (2015).

14 Ibidem. 
Jadwiga Suchecka, Maciej Jewczak

się i rozwoju rynku zdrowia dla korzyści starszej populacji, a także innowacji w zakresie organizacji lub transformacji opieki, stworzenia map interesariuszy, prototypów i produktów.

\section{Bibliografia}

Abramowska-Kmon, A. (2011). O nowych miarach zaawansowania procesu starzenia się ludności. Studia Demograficzne 1(159).

Kaa van de, D.J. (1987). Europe's Second Demographic Transition. Population Bulletin, 42(1).

Kinsell, K., Gist, Y.J. (1995). Older Workers, Retirement, and Pensions. A Comparative International Chartbook. Biuro Spisu Powszechnego USA, Report IPC/95-2RP, U.S. Government Printing Office.

Kotowska, I.E., Jóźwiak, J. (2012). Nowa demografia Europy a rodzina. Roczniki Kolegium Analiz Ekonomicznych (28).

Maksimowicz, A. (1990). Przemiany struktury ludności według wieku. W: Okólski, M. (red.). Teoria przejścia demograficznego. Warszawa: Państwowe Wydawnictwo Ekonomiczne.

Martin, L.G., Preston, S.H. (red.) (1994). Demography of Aging. Committee on Population. Washington: National Academy Press.

National Research Council (2001). Preparing for an Aging World: The Case for Cross-National Research. Panel on a Research Agenda and New Data for an Aging World. Washington: National Academy Press.

Phillips, D., Bartlett, H.P. (1995). Aging Trends-Singapore. Journal of Cross-Cultural Gerontology 10(4).

Rossi, G., Boccacin, L., Bramanti, D., Meda, S.G. (2014). Active Ageing: Intergenerational Relationships and Social Generativity, Active Ageing and Healthy Living. Open Access by IOS Press.

Smith, J.P. (1999). Healthy Bodies and Thick Wallets: The Dual Relationship between Health and Economic Status. Journal of Economic Perspectives, 13.

Suchecka, J., Urbaniak, B. (2016). Determinants of Health Ageing for Older People in European Countries - A Spatio-Temporal Approach. Comparative Economic Research Central and Eastern Europe, 5 (Wydawnictwo Uniwersytetu Lódzkiego).

Trzpiot, G. (2013). Zmiany struktury demograficznej państw UE: wyzwanie dla logistyki społecznej. Studia Ekonomiczne Uniwersytetu Ekonomicznego w Katowicach. Seria Zeszyty Naukowe Wydziatowe, 175.

United Nations, Department of Economic and Social Affairs, Population Division (2015). World Population Prospects: The 2015 Revision. New York: United Nations.

Żołędowski, C. (2012). Starzenie się ludności - Polska na tle Unii Europejskiej. Problemy Polityki Spotecznej, Studia i Dyskusje, 17. Warszawa: Komitet Nauk o Pracy i Polityce Społecznej. Uniwersytet Warszawski, Instytut Polityki Społecznej.

\section{Źródła internetowe:}

Active Ageing and Solidarity between Generations. A Statistical Portrait of the Unions 2012. Eurostat, EC.

Decision No. 940/2011/UE of the European Parliament and of the Council of 14.09.2011 on the European Year for Active Ageing and Solidarity between Generations (2012). 
European Commission and Social Protection Committee (2013). Long-term Care in Ageing Societies - Challenges and Policy Options. Brussels

European Commission (2015). Growing the Silver Economy in Europe. Background Paper, 23.02 .

A Common Narrative on the EU Silver Economy (2015). Growing the Silver Economy in Europe, Background Paper, s. 4.

EUROPOP (2013). http://ec.europa.eu/eurostat/statistics-explained/index.php/People_in_ the_EU_\%E2 \%80\%93_population_projections\#Europop2013_.E2.80.94_population_ projections.

Eurostat (2012). Active Ageing and Solidarity between Generations. A Statistical Portrait of the Unions. EC.

The Ageing Report: Economic and Budgetary Projections for the 27 EU Member State (2010-2060). European Economy 2/2012. Joint Report Prepared by the European Commission (DG EFIN) and Economic Policy Committee (AWG).

World Health Organisation (2002). Active Ageing. A Policy Framework. 



\title{
Józef Haczyński ${ }^{1}$
}

\section{Skutki starzenia się polskiego społeczeństwa}

\begin{abstract}
Streszczenie
Starzenia się ludności jest związane z bezpośrednim i pośrednim wpływem wielu czynników i ma nie tylko wymiar demograficzny, ale także rodzi reperkusje ekonomiczne i społeczne. Z prognozy demograficznej na lata 2014-2029 wynika, że liczba ludności Polski spadnie o 1,2 mln, zwłaszcza w grupie wiekowej 20-44 lat. Równocześnie nastąpi znaczny wzrost udziału osób w wieku 65 lat i więcej. Postępujący proces starzenia się społeczeństwa jest dużym wyzwaniem dla decydentów, wymagającym długoterminowych, szeroko zakrojonych i centralnie koordynowanych działań w wielu dziedzinach.

W niniejszej pracy starzenie się społeczeństwa zostało przedstawione w trzech odrębnych aspektach: demograficznym, konsekwencjach społeczno-ekonomicznych i w kontekście zdrowia seniorów. Bez natychmiastowego i znaczącego zaangażowania państwa w realizację i osiągnięcie celów, uwzględniających potrzeby starzejącego się społeczeństwa, opieka nad osobami starszymi będzie niewystarczająca, a tym samym dojdzie do nadmiernego obarczenia dodatkowymi obowiązkami i kosztami rodzin osób starszych.
\end{abstract}

Słowa kluczowe: starzenie się, ochrona zdrowia w geriatrii, choroby przewlekłe, niedobory kadry medycznej.

\section{The Effects of Polish Population Ageing}

\begin{abstract}
Population ageing involves a direct and indirect impact of many factors and not only has a demographic dimension but also leads to economic and social repercussions. The demographic forecast for 2014-2029 shows that the Polish population will decrease by 1.2 million people,

1 Józef Haczyński, dr hab. nauk medycznych, Dyrektor Centrum Zarządzania w Ochronie Zdrowia Wydziału Zarządzania Uniwersytetu Warszawskiego, ul. Szturmowa 1/3, 02-678 Warszawa, profesor na Wydziale Lekarskim i Nauk o Zdrowiu Uniwersytetu Zielonogórskiego, ul. Zyty 28, 65-046 Zielona Góra, e-mail: jhaczynski@wz.uw.edu.pl; ORCID: 0000-0002-8971-2287.
\end{abstract}


notably in the 20-44 age group. At the same time, the share of those aged 65 and more will significantly increase. Progressive population ageing is a big challenge for decision-makers, requiring long-term, extensive and centrally coordinated actions in many areas.

The chapter presents population ageing in three separate aspects: demographic, socio-economic consequences, and in the context of seniors' health. Without immediate and considerable involvement of the state in the implementation and achievement of objectives taking into account the needs of an ageing population, care for the elderly will be insufficient, and thus excessive burden of additional responsibilities and costs will be imposed on families of seniors.

Keywords: ageing, geriatric healthcare, chronic diseases, medical staff shortages.

\section{Wstęp}

Proces starzenia się jest naturalnym zjawiskiem biologicznym i dotyczy wszystkich organizmów żywych. W ostatnich dziesięcioleciach jest obserwowane narastające zjawisko starzenia się społeczeństw. Rozwój społeczno-gospodarczy Polski oraz dokonujący się postęp technologiczny w medycynie wpływają znacząco na zmiany w strukturze wiekowej ludności, przyczyniając się nie tylko do wydłużenia życia i poprawy jego jakości, lecz także do zmian częstości występowania chorób i problemów medycznych. Jednocześnie są obserwowane zmiany w obrębie modelu rodziny, będące przyczyną m.in. obniżenia współczynników rodności i dzietności polskich rodzin.

Współczynnik rodności jest miernikiem natężenia urodzeń żywych i liczony jest jako stosunek liczby żywych urodzeń z badanej zbiorowości w określonym czasie do liczby ludności w połowie okresu lub do średniej liczby ludności. Współczynnik rodności opisuje aktualny poziom urodzeń, a jego wartość w istotny sposób zależy od struktury społeczeństwa według płci i wieku, zwłaszcza od udziału ludności w wieku zdolności rozrodczej i struktury populacji w wieku rozrodczym oraz od postaw i zachowań prokreacyjnych.

Współczynnik dzietności określa liczbę urodzonych dzieci przypadających na jedną kobietę w wieku rozrodczym (15-49 lat). Przyjmuje się, że współczynnik dzietności między 2,10 a 2,15 jest wartością zapewniającą prostą zastępowalność pokoleń.

Wobec niskiej liczby urodzeń oraz wydłużania się przeciętnego trwania życia ludzkiego zwiększa się zarówno liczba, jak i odsetek osób starszych oraz zmniejsza się zastępowalność pokoleń - co powoduje przesunięcie odpowiedzialności za opiekę nad osobami starszymi z rodziny na instytucje państwowe. Równocześnie decydenci stają wobec dylematu, w jaki sposób poprawić sytuację demograficzną kraju. Czy prowadzić politykę pronatalistyczną i prorodzinną, czy też skierować działania na imigrację siły roboczej z krajów o większej 
dzietności? W obu przypadkach szybciej lub wolniej dochodziłoby do rozłożenia ciężaru utrzymania osób starszych na osoby młodszej generacji. Równocześnie, aby utrzymać wysokość świadczeń emerytalno-rentowych i odpowiedni poziom opieki zdrowotnej nad osobami starszymi, można rozważać zwiększenie obciążeń fiskalnych, nakładanych na wynagrodzenia osób aktywnych zawodowo, zwiększenie atrakcyjności różnych programów emerytalnych lub wydłużenie okresu aktywności zawodowej. Subpopulacja osób starszych jest zbiorowością niejednorodną.

Światowa Organizacja Zdrowia (WHO) za początek starości uznaje 60 rok życia i wyróżnia trzy etapy starości w zależności od przedziałów wiekowych (http://www.who.int/kobe_centre/ageing/ahp_vol5_glossary.pdf?ua=1; dostęp: 10.09.2017). Przedział wiekowy 60-74 lat jest uznawany za „młodą” starość (III wiek, young old), przedział wiekowy 75-89 lat jest „dojrzałą” starością (IV wiek, oldest old), a wiek 90 lat i więcej jest definiowany jako długowieczność (oldest old, long life). Każda z tych grup wiekowych ma inne potrzeby, zarówno wynikające z problemów medycznych, jak i w zakresie wsparcia socjalnego czy psychologicznego.

Na zjawisko starzenia się ludności wpływa pośrednio szereg czynników, jak np.: poziom zamożności społeczeństwa, promowany model rodziny, aktywność zawodowa kobiet, poziom opieki społecznej i ochrony zdrowia, wykształcenie ludności oraz polityka społeczna państwa. Proces starzenia się ma więc nie tylko wymiar demograficzny, lecz także rodzi reperkusje ekonomiczne i społeczne. Proces ten generuje zmiany w strukturze konsumpcji, wywołuje wzrost zapotrzebowania na niektóre usługi, np. w dziedzinie ochrony zdrowia czy opieki społecznej, powoduje zmniejszenie aktywności zawodowej, zwiększenie wydatków na utrzymanie rosnącej grupy poprodukcyjnej, zmianę struktury siły roboczej, rodziny i gospodarstw domowych.

\section{Demografia starzenia się populacji polskiej}

Badania demograficzne wskazują, że największy wpływ na dynamikę procesu starzenia się społeczeństwa ma natężenie urodzeń. Duża liczba urodzeń przyczynia się do wzrostu udziału dzieci w strukturze populacji, a co za tym idzie - do „odmłodzenia” populacji.

Wydłużenie życia ludności najstarszej przyspiesza zjawisko starzenia się społeczeństwa, natomiast wzrost wskaźnika przeżywalności noworodków działa na nie hamująco (zob. Starzenie się społeczeństwa polskiego..., 2011, s. 3, 4).

W Polsce, po powojennym „boomie urodzeniowym”, od końca lat 50. XX wieku dzietność zmniejszała się, a proces ten trwał do początku lat 
70. XX wieku, kiedy to w wiek największej aktywności prokreacyjnej weszły roczniki kobiet $\mathrm{z}$ wyżu demograficznego lat 50 . XX wieku, co spowodowało znaczący wzrost liczby urodzeń. Wzrost dzietności utrzymywał się do 1983 roku - współczynnik dzietności wyniósł w 1978 roku 2,205 i w 1983 roku 2,416. W następnych latach obserwowano systematyczny spadek współczynnika dzietności. Rok 2003 był w Polsce rokiem o rekordowo niskiej liczbie urodzeń - tylko nieco ponad 351 tys. (współczynnik dzietności był rekordowo niski i wyniósł tylko 1,22). W kolejnych latach obserwowano niewielki wzrost liczby urodzeń - w 2009 roku współczynnik dzietności wyniósł około 1,4. Począwszy od 2011 roku obserwowano ponownie spadek liczby urodzeń (współczynnik dzietności w 2015 roku wyniósł 1,29). Dopiero wprowadzenie w życie programu „Rodzina 500+” przyniosło w 2016 roku wzrost współczynnika dzietności do 1,36 (zob. Prognoza ludności na lata 2014-2050).

Wykres 1. Współczynniki dzietności kobiet i udział kobiet w wieku 15-49 lat w ogólnej liczbie kobiet w Polsce w latach 1990-2013

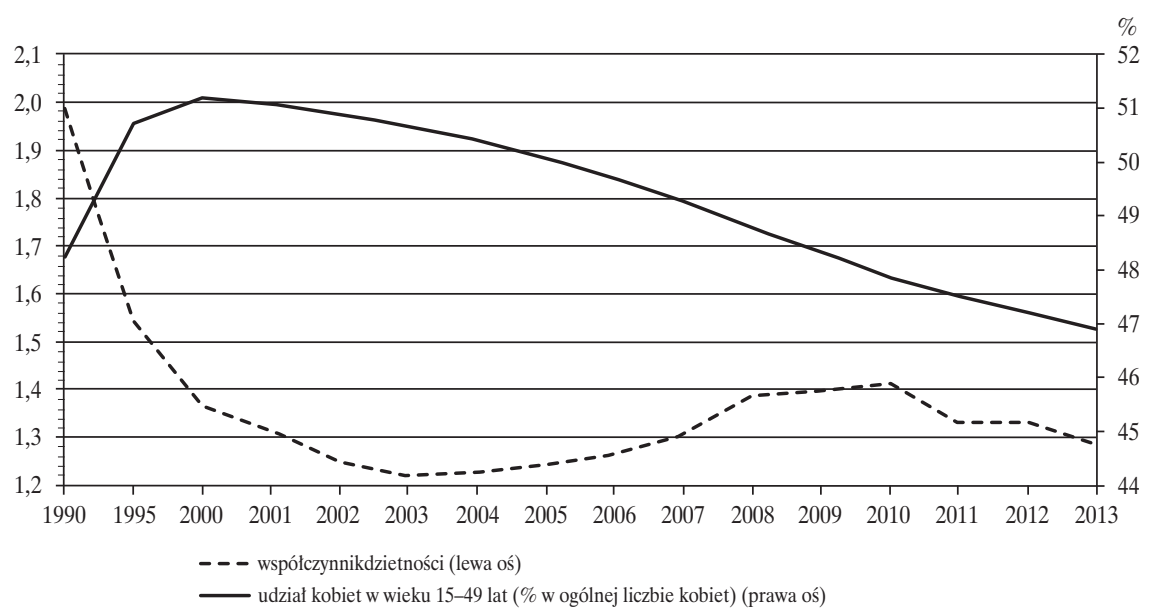

Źródło: Małżeństwa oraz dzietność w Polsce (2016, wykres 5, s. 5).

Charakterystycznym zjawiskiem dla Polski po 1989 roku był także wzrost średniego wieku rodzenia dziecka (MAC - mean age of childbearing). O ile w 1990 roku wynosił on 26,2 lat, w 2000 roku - 27,4 lat, to w 2013 roku - już 29,0 lat. Opóźnienie macierzyństwa jest charakterystyczną cechą zachowań prokreacyjnych, obserwowanych w innych krajach europejskich już od lat 60. XX wieku. Pomimo znacznego wzrostu MAC, Polska i tak nadal należy do krajów o stosunkowo niskim wieku macierzyństwa (Ibidem, s. 37). 
Wykres 2. Urodzenia żywe w Polsce według wieku matki w latach 1990-2013 (w \%)

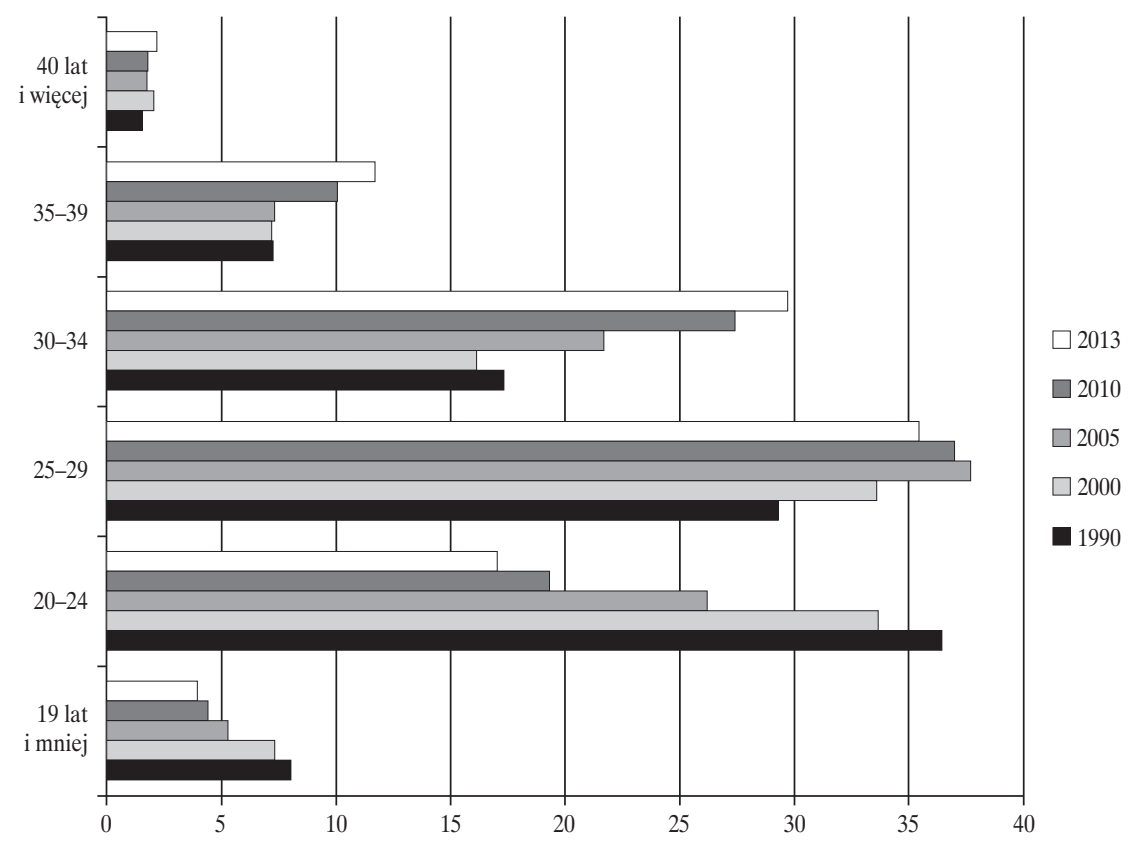

Źródło: Matżeństwa oraz dzietność w Polsce (2016, wykres 6, s. 6).

Szybki postęp w dziedzinie medycyny - wcześniejsze i dokładniejsze diagnozowanie chorób, skuteczniejsze ich leczenie, prowadzenie zdrowego stylu życia, zmiana diety, jak również działania rządu prowadzące do zapewnienia odpowiednich warunków życia, pracy, kształcenia, kultury fizycznej oraz wypoczynku i rekreacji wpływają na stałą poprawę kondycji zdrowotnej Polaków, a tym samym ich dłuższe życie.

W latach 1991-2013 przeciętny okres życia mężczyzn w Polsce zwiększył się o 7,2 lat, natomiast kobiet o 6 lat. W 2013 roku przeciętny okres przeżycia noworodka płci męskiej wynosił 73,1 lata, natomiast noworodka płci żeńskiej $-81,1$ lat.

Według danych GUS przeciętna długość życia mężczyzn w Polsce będzie systematycznie wzrastała do ponad 77,5 lat w 2030 roku i 81,8 lat w 2050 roku w porównaniu do 73,1 lat w 2013 roku (Ibidem). Nieco wolniejszy wzrost długości życia prognozowany jest dla polskich kobiet i wynosi odpowiednio: 84,4 lat w 2030 roku i 87,6 lat w 2050 roku. Przyjmując za miarę zaawansowania procesu starzenia się medianę wieku przewiduje się, że w 2050 roku mediana 
wzrośnie do 48,8 lat dla mężczyzn i do 53,7 lat dla kobiet, co oznacza w skali kraju wzrost o odpowiednio 10,9 i 12,3 lat w porównaniu do 2014 roku.

Występujące w Polsce zjawisko nadumieralności mężczyzn utrzymuje się od lat na wysokim poziomie. Dysproporcja pomiędzy przeciętnym trwaniem życia mężczyzn i kobiet w 1991 roku wynosiła aż 9,2 lat i ulegała stopniowemu obniżaniu w kolejnych latach - do 8 lat w 2013 roku. Nadal jednak długość życia zarówno Polek, jak i Polaków jest mniejsza niż obywateli wielu krajów Europy Zachodniej. W kolejnych latach powinna być obserwowana tendencja zmniejszania się nadumieralności mężczyzn, a tym samym rozpiętość między przeciętnym trwaniem życia mężczyzn i kobiet powinna stopniowo maleć.

Analiza danych z opublikowanego przez GUS w 2014 roku opracowania Prognoza ludności na lata 2014-2050 pozwala na stwierdzenie, że Polskę czeka dalszy, stopniowy ubytek liczby ludności oraz znaczące zmiany jej struktury według wieku (załącznik - tabela 1). Oba te fakty wynikają z mechanizmów powiązań między natężeniem urodzeń i zgonów a stanem ludności. Spodziewana poprawa płodności, jaka pojawiła się po 2004 roku, okazała się zbyt słaba, aby przynieść wymierne efekty dla wielkości i struktury populacji według wieku. Długotrwały spadek urodzeń zapoczątkowany po 1983 roku i utrzymujące się niskie natężenie urodzeń spowodowały, że w wiek prokreacji wchodzą coraz mniej liczne roczniki. Polska znalazła się w takim momencie rozwoju demograficznego, że nawet wzrost współczynnika dzietności do poziomu gwarantującego prostą zastępowalność pokoleń w krótkim okresie nie spowoduje odwrócenia tych procesów i nie powstrzyma zmniejszania się liczby ludności kraju. Przy tak już znacznym zniekształceniu struktury populacji proces odbudowy demograficznej jest procesem powolnym i wymaga konsekwentnych, długofalowych działań.

Z prognozy demograficznej na lata 2014-2029 wynika, że liczba ludności Polski spadnie o 1,2 mln osób - z 38,5 mln do 37,3 mln (czyli o około 3\%). Zgodnie z przewidywaniami prognozy nastąpi istotne zmniejszenie udziału ludności w wieku 20-44 lat oraz znaczny wzrost udziału osób w wieku 65 lat i więcej. Osób w wieku co najmniej 65 lat będzie 8,5 mln w 2029 roku i będą one stanowiły $23 \%$ ogółu populacji (wobec $15,3 \%$ w 2014 roku).

W 2050 roku liczba ludności rezydującej Polski wyniesie 34856 tys. Oznacza to dalsze zmniejszanie się liczby ludności o około $3,15 \mathrm{mln}$, tj. o 8,3\% w porównaniu do 2014 roku. Po 2030 roku w każdym pięcioleciu prognozowanego okresu do 2050 roku, przewidywane jest zmniejszenie liczebności populacji o ponad 500 tys. Najwyższe ubytki wystąpią w latach 2035-2045. W okresie tych 10 lat populacja Polski skurczy się o 1,24 mln. Oprócz ujemnego przyrostu 
naturalnego, będziemy obserwować dalsze niekorzystne zmiany w strukturze ludności według wieku oraz zmniejszanie się liczebności kobiet w wieku rozrodczym. Osoby w wieku 65 lat i więcej będą stanowity 31,5\% populacji, a ich liczba wzrośnie o 5,1 mln w porównaniu do 2014 roku. Z kolei kobiety w wieku rozrodczym w 2050 roku będą stanowity tylko $67 \%$ stanu z początkowego roku analizy (Ibidem).

\section{Konsekwencje społeczno-ekonomiczne starzenia się społeczeństwa}

Od wielu lat jest odnotowywany narastający proces starzenia się społeczeństw w licznych krajach na świecie. W Europie odsetek osób w wieku 60 lat i więcej wzrasta $\mathrm{w}$ nieobserwowanym dotąd tempie, wynosząc obecnie około $15 \%$ populacji, a według danych szacunkowych odsetek ten ulegnie podwojeniu do 2050 roku i będzie wynosił około $30 \%$ ludności państw europejskich (Gryglewicz 2017, s. 22, 23).

W opublikowanym w 2017 roku raporcie OECD Preventing Ageing Unequally wskazano m.in., że o ile na każde 100 osób w wieku produkcyjnym w 2015 roku w krajach OECD było 28 osób w wieku emerytalnym, to w 2050 roku ich liczba wzrośnie do 53 osób (wykres 3).

Wykres 3. Liczba osób w wieku $65+$ przypadająca na 100 osób w wieku produkcyjnym (20-64) w krajach OECD

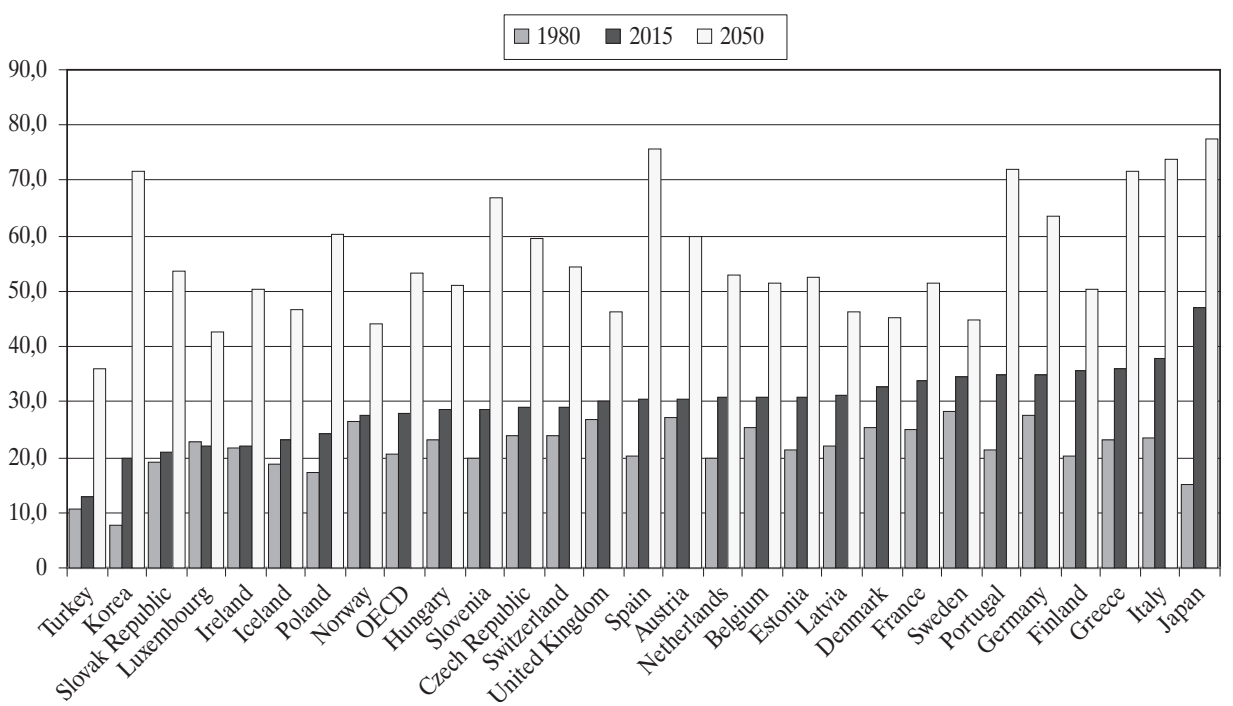

Źródło: opracowanie własne na podstawie: OECD (2017, tabela 1.1.). 
W ostatnich 35 latach (1980-2015) wśród krajów OECD najbardziej zestarzało się społeczeństwo Japonii - liczba osób w wieku 65+, przypadająca na każde 100 osób w wieku zdolnym do pracy, wzrosła z 18 do prawie 50. Szybko starzały się także społeczeństwa europejskich krajów: Finlandii, Grecji, Włoch i Portugalii (OECD, 2017, s. 21).

Najwolniej starzeją się społeczeństwa Meksyku i Turcji - w tych krajach na 100 osób w wieku produkcyjnym przypada zaledwie kilkanaście osób w wieku emerytalnym.

W Irlandii, Luksemburgu, Norwegii i Słowacji liczba emerytów, przypadających na 100 osób w wieku produkcyjnym przewyższa nieco 20. Na podkreślenie zasługuje fakt, że w tych krajach proporcje emerytów do osób w wieku produkcyjnym nie uległy od 1980 roku większym zmianom.

Sytuacja Polski na tym tle nie wygląda korzystnie. O ile zarówno w 1980, jak i 2015 roku relacja liczby osób w wieku emerytalnym do liczby osób w wieku produkcyjnym była niższa niż średnia dla krajów OECD, to - zgodnie z prognozą - w 2050 roku na 100 osób w wieku zdolnym do pracy będzie przypadać ponad 60 osób w wieku emerytalnym (przy średniej dla krajów OECD - około 50). Społeczeństwo polskie - obok mieszkańców Korei Południowej, Portugalii, Hiszpanii, Grecji i Włoch - będzie w najbliższych 35 latach starzało się w najszybszym tempie. Wynika to zarówno $\mathrm{z}$ wchodzenia w wiek emerytalny pokolenia wyżu demograficznego z lat 50. XX wieku, jak i z wydłużającego się czasu życia, a tym samym - czasu spędzanego na emeryturze (Ibidem, s. 21, 22).

Należy mieć świadomość faktu, że chociaż wzrasta długość życia - to nie wiąże się ten fakt $\mathrm{z}$ wydłużaniem się czasu pracy. Nie chodzi tylko o wyznaczanie oficjalnej granicy wieku emerytalnego, lecz także o czas efektywnie przepracowany - doświadczenia ostatniego kryzysu finansowego wskazują, że pogarszają się perspektywy utrzymania stabilnej pracy i płacy. Ma to bezpośredni wpływ na wysokość kumulowanych w gospodarkach środków, które są podstawą przyszłych emerytur (https://www.obserwatorfinansowy.pl/tematyka/.../najlepiej-byc-zdrowym-i-pracowity; dostęp: 04.12.2017).

Przygotowany w 2015 roku przez Komisję Europejską The 2015 Ageing Report (European Economy, 2015/3) również wskazuje Polskę jako jeden z krajów, który w największym stopniu zostanie dotknięty zjawiskiem starzenia się społeczeństwa (prognozy zawarte w tym raporcie sięgają aż do 2060 roku). Zgodnie z prognozami Komisji Europejskiej do 2060 roku populacja Polski zmniejszy się o około $5 \mathrm{mln}$ osób, a liczba osób w wieku produkcyjnym - spadnie o $9 \mathrm{mln}$ (z około $27 \mathrm{mln}$ do $18 \mathrm{mln}$ ). Szczególnie silny spadek będzie dotyczyć grupy w wieku 25-54 lata, która w 2013 roku stanowiła 43,6\% społeczeństwa, a w 2060 roku - zmniejszy się do 33\%. Stosunek osób niepracujących 
w wieku 65 + do liczby pracujących zmniejszy się z 33\% w 2013 roku do ponad 80\% w 2060 roku - będzie to najwyższy wzrost wśród krajów Unii Europejskiej.

Tabela 1. Liczba i struktura według wieku mieszkańców Polski w 2013 roku oraz prognoza na lata 2020-2060

\begin{tabular}{|l|c|c|c|c|c|c|c|c|c|c|}
\hline & $\mathbf{2 0 1 3}$ & $\mathbf{2 0 2 0}$ & $\mathbf{2 0 2 5}$ & $\mathbf{2 0 3 0}$ & $\mathbf{2 0 3 5}$ & $\mathbf{2 0 4 0}$ & $\mathbf{2 0 4 5}$ & $\mathbf{2 0 5 0}$ & $\mathbf{2 0 5 5}$ & $\mathbf{2 0 6 0}$ \\
\hline Ogółem (mln) & 38,5 & 38,4 & 38,0 & 37,5 & 36,8 & 36,2 & 35,5 & 34,8 & 34,0 & 33,2 \\
\hline W tym: (\%) & & & & & & & & & & \\
\hline Dzieci (0-14) & 15,0 & 15,3 & 14,5 & 13,6 & 12,8 & 12,6 & 12,9 & 13,2 & 13,2 & 13,0 \\
\hline $\begin{array}{l}\text { Populacja } \\
\text { w wieku 25-54 lata }\end{array}$ & 43,6 & 43,0 & 42,4 & 40,7 & 38,8 & 36,3 & 34,8 & 33,8 & 33,5 & 33,6 \\
\hline $\begin{array}{l}\text { Pracujący } \\
\text { w wieku 15-64 lat }\end{array}$ & 70,5 & 66,3 & 64,3 & 63,7 & 63,5 & 62,2 & 59,8 & 56,9 & 55,0 & 54,1 \\
\hline $\begin{array}{l}\text { Populacja osób } \\
\text { powyżej 65 roku życia }\end{array}$ & 14,5 & 18,4 & 21,2 & 22,7 & 23,7 & 25,1 & 27,3 & 29,9 & 31,8 & 33,0 \\
\hline $\begin{array}{l}\text { Populacja osób } \\
\text { w wieku 80 lat } \\
\text { i więcej }\end{array}$ & 3,8 & 4,4 & 4,4 & 5,8 & 7,7 & 9,2 & 9,5 & 9,5 & 10,4 & 12,3 \\
\hline
\end{tabular}

Źródło: zestawienie własne na podstawie: The 2015 Ageing Report, European Economy 2015/3. Economic and Financial Affairs, Economic and Budgetary Projections for the 28 EU Member States (2013-2060). European Union 2016, s. 379.

$\mathrm{Z}$ zestawienia zaprezentowanego w tabeli 1 wynika, że udział populacji „65+” w polskim społeczeństwie będzie systematycznie rósł: z rzeczywistego poziomu 14,5\% w 2013 roku do prognozowanych: 25\% w 2040 roku i 33\% w 2060 roku. Udział populacji osób w wieku „80 lat i więcej”, który w 2013 roku wynosił tylko 3,8\% jest prognozowany jako 9,2\% w 2040 roku i 12,3\% w 2060 roku.

Poza kwestiami związanymi z obciążeniami finansowymi państwa, w związku z koniecznością długotrwałego wypłacania rent i emerytur, należy zwrócić uwagę na narastające problemy zdrowotne osób w sędziwym wieku.

W pierwszej połowie 2015 roku Główny Urząd Statystyczny przeprowadził badanie ankietowe polskich gospodarstw domowych nt. „Badanie spójności społecznej" na reprezentatywnej próbie prawie 14 tys. mieszkańców w wieku co najmniej 16 lat.

Prezentowane poniżej dane dotyczą osób w wieku „65 lat i więcej”, pochodzą z wyżej wspomnianego badania, a prezentują sytuację materialną tej grupy 
osób, ujętą w aspekcie skrajnych pojęć: „ubóstwa” i „dobrej sytuacji” gospodarstwa domowego osób starszych.

Analiza wyników badań prowadzi do następujących wniosków:

- $12 \%$ gospodarstw domowych osób starszych cechowało tzw. ubóstwo dochodowe, tzn. miesięczny dochód ekwiwalentny, jakim dysponowało gospodarstwo (w 12 miesiącach poprzedzających badanie) był niższy od wartości uznanej za próg ubóstwa. Próg ubóstwa przyjęto na poziomie $60 \%$ mediany dochodu ekwiwalentnego, czyli porównywalnego między gospodarstwami o różnym składzie demograficznym;

- 8\% gospodarstw domowych osób starszych cechowało tzw. ubóstwo warunków życia, tzn. zaobserwowano w nich co najmniej 10 przejawów złych warunków życia z listy 30 symptomów dotyczących: jakości mieszkania, poziomu wyposażenia w dobra trwałego użytku, deprywacji różnego typu potrzeb konsumpcyjnych (materialnych i niematerialnych);

- 9\% gospodarstw domowych osób starszych doświadczyło tzw. ubóstwa braku równowagi budżetowej, tzn. uznano je za ubogie z punktu widzenia „nieradzenia sobie z budżetem” (wystąpiły w nich przynajmniej 4 z 7 uwzględnionych symptomów, obejmujących zarówno opinie gospodarstw domowych dotyczące ich statusu materialnego, jak i fakty mówiące o trudnościach budżetowych gospodarstwa, w tym o zaległościach w opłatach).

Równocześnie stwierdzono, że:

- $11 \%$ gospodarstw domowych ludzi starszych osiągnęło tzw. najwyższe dochody, tzn. należało do grupy, w której miesięczny dochód ekwiwalentny był wyższy niż 5/3 (około 167\%) mediany dochodu ekwiwalentnego, tj. około 2,8 razy wyższy od przyjętej relatywnej granicy ubóstwa;

- $22 \%$ gospodarstw ludzi starszych osiągnęło tzw. wskaźnik dobrych warunków życia, tzn. że w tych gospodarstwach nie stwierdzono występowania żadnego przejawu złych warunków życia z listy 30 symptomów;

- $21 \%$ gospodarstw domowych ludzi starszych osiągnęło tzw. wskaźnik dobrej sytuacji budżetowej, tzn. należało do grupy gospodarstw o największej swobodzie budżetowej - takich, które pozytywnie oceniały możliwości gospodarowania swoimi dochodami i w których nie wystąił żaden z 7 symptomów „nieradzenia sobie z budżetem”2.

\footnotetext{
Jakość życia osób starszych w Polsce na podstawie wyników Badania Spójności Społecznej 2015. GUS. Departament Badań Społecznych i Warunków Życia. Urząd Statystyczny w Łodzi, www.stat.gov.pl
} 
A zatem nie należy jednoznacznie twierdzić, iż gospodarstwa domowe osób starszych są gospodarstwami będącymi w złej sytuacji materialnej.

Osoby w wieku 65 lat i więcej niewątpliwie częściej chorują, w tym: na choroby przewlekłe, wymagające ciągłego brania leków i systematycznej opieki medycznej; wśród osób starszych jest wyższy odsetek osób niepełnosprawnych niż w populacji młodych.

Częstość występowania tych schorzeń wzrasta wraz z wiekiem, szczególnie nasilony wzrost schorzeń jest obserwowany po ukończeniu 50. roku życia. Prawie $83 \%$ osób będących w wieku 50 lat i więcej stwierdziło występowanie u siebie obecnie przynajmniej jednej choroby lub dolegliwości przewlekłej, podczas gdy w młodszej grupie (40-49 lat) - trochę częściej niż co druga osoba (Stan zdrowia ludności Polski w 2014 r., 2016, s. 65).

Według metodologii Eurostatu w Polsce pod koniec 2014 roku żyło blisko 7,7 mln osób niepełnosprawnych, czyli osób, które twierdziły, iż z powodu problemów zdrowotnych miały ograniczoną zdolność wykonywania czynności, jakie ludzie zwykle wykonują (uwzględniono poważne i mniej poważne ograniczenia). Nie był natomiast brany pod uwagę aspekt posiadania prawnego orzeczenia o niepełnosprawności.

Osobą niepełnosprawną można się stać w każdym wieku, ale w ciągu trwania życia na skutek urazów, wad wrodzonych, chorób przewlekłych pogarsza się często stan zdrowia, uniemożliwiając w różnym stopniu normalne funkcjonowanie. Rozmiary niepełnosprawności określają wyraźnie kondycję zdrowotną społeczeństwa, gwałtownie zwiększając się wraz z wiekiem. Częstość występowania niepełnosprawności rośnie gwałtownie po ukończeniu 50. roku życia. Według kryteriów unijnych wśród pięćdziesięciolatków co czwarta osoba została zaliczona do grupy osób niepełnosprawnych, a wśród siedemdziesięciolatków - blisko 3/5 tej zbiorowości (Ibidem, s. 106, 107).

Często trudna sytuacja życiowa seniorów może wynikać nie tylko ze stanu zdrowia i stopnia sprawności, ale również z braku wsparcia ze strony osób najbliższych. Taka sytuacja jest przyczyną osamotnienia, stanów depresyjnych i lękowych, pogorszenia jakości życia i zaburzeń emocjonalnych. Ważnym aspektem jest budowanie świadomości wśród osób bezdzietnych lub żyjących samotnie o konieczności posiadania dodatkowego ubezpieczenia lub zwiększonych oszczędności indywidualnych, które można będzie w przyszłości przeznaczyć na opiekę.

Kolejnym istotnym problemem seniorów może być nadmiar wolnego czasu i brak możliwości jego wykorzystania w sposób wartościowy z punktu widzenia 
indywidualnego, rodzinnego i społecznego, jak i tendencja do wycofywania się i rezygnacji z wielu aspektów życia.

Wydłużenie życia osób najstarszych jest odpowiedzialne za zjawisko starzenia się społeczeństwa, natomiast wzrost wskaźnika przeżywalności noworodków działa na nie hamująco. Od co najmniej 25 lat zmniejsza się w Polsce i w Europie liczba urodzeń, prowadząc do podwyższenia średniego wieku populacji oraz zwiększenia odsetka populacji starszej. Działania państwa w tym zakresie polegały w Polsce na wprowadzeniu w 2007 roku ulg podatkowych zależnych od liczby posiadanych dzieci oraz na wprowadzeniu od 1 kwietnia 2016 roku rządowego programu „Rodzina 500+”, mającego pomóc rodzinom w wychowaniu dzieci poprzez comiesięczne świadczenia wychowawcze na drugie i każde kolejne dziecko w rodzinie w wysokości 500 złotych. Warunkiem otrzymania świadczenia na pierwsze dziecko jest spełnienie kryterium dochodowego. Program „Rodzina 500+” został wprowadzony w życie na podstawie Ustawy z dnia 11 lutego 2016 roku o pomocy państwa w wychowywaniu dzieci (DzU z 2017 r. poz. 1851). Dane, które były upowszechniane publicznie mówiły, że w pierwszych 10 miesiącach 2017 roku zarejestrowano o ponad 14 tys. więcej ciąż w porównaniu do odpowiedniego okresu rok wcześniej. To daje wzrost na poziomie mniej więcej 4-5\% w skali rocznej (http://www.gazetaprawna.pl/artykuly/1016288, nie-tylko-500-plus-wplywa-na-zwiekszenie-liczbyurodzen.html). Jednak na wymierne wyniki programu trzeba jeszcze poczekać.

Kolejnymi przyczynami zmniejszonej liczby urodzeń jest też: podjęcie decyzji o pierwszej ciąży w późniejszym wieku po zakończeniu coraz dłuższego okresu nauki i osiągnięciu stabilizacji zawodowej, zwiększająca się liczba jednoosobowych gospodarstw domowych i osób samotnych oraz spadek liczby zawieranych małżeństw. Osoby samotne lub osoby żyjące w związkach nieformalnych rzadziej decydują się na posiadanie dzieci niż osoby będące w związkach. W wyniku opisywanego kryzysu demograficznego jest obserwowany postępujący proces wyludniania się małych miejscowości w wyniku migracji do miast i emigracji młodych osób w wieku przedprodukcyjnym (w poszukiwaniu lepszego wykształcenia) lub $\mathrm{w}$ wieku produkcyjnym $\mathrm{w}$ celu poszukiwania lepszej pracy. Brak dzieci w wieku szkolnym skutkuje zamykaniem wiejskich szkół, który to proces pogłębia degradację społeczną i kulturalną polskiej prowincji.

\section{Zdrowie seniorów}

Obserwowane globalne starzenie się społeczeństwa niewątpliwie jest wyznacznikiem postępu medycyny, postępu społecznego i gospodarczego. Jed- 
nak stanowi ono bardzo duże wyzwania, które mają wpływ na wzrost gospodarczy, formalne i nieformalne systemy wsparcia starzejącej się społeczności oraz wydolność państw i społeczeństwa w celu zapewnienia zasobów dla starszych obywateli. Niewątpliwie dla służby zdrowia, opieki społecznej i polityki społecznej państwa jest to jedno z największych wyzwań, wymagające szybkiego działania, mającego na celu dostosowanie zasobów do potrzeb starzejącego się społeczeństwa. Rozpatrywanie tego zjawiska w kontekście ekonomicznym pokazuje zmiany struktury konsumpcji, zwiększające się zapotrzebowanie na niektóre usługi związane z niepełnosprawnością, chorobami przewlekłymi, potrzebą zapewnienia opieki. Należy rozpatrywać również zmniejszenie aktywności zawodowej tej grupy społecznej oraz zwiększenie wydatków na utrzymanie rosnącej grupy poprodukcyjnej czy zmiany w zakresie struktury i wydatków gospodarstw domowych. Osoby powyżej 65 roku życia zwykle cierpią na różne choroby, zarówno przewlekłe schorzenia, jak i degeneracyjne.

Najczęstszymi dolegliwościami są choroby z grupy sercowo-naczyniowej, takie jak: miażdżyca, nadciśnienie, udar mózgowy, choroba niedokrwienna serca i jej następstwo, czyli zawał mięśnia serca. Wraz z wiekiem następuje pogorszenie sprawności kognitywnych, różnorakie uszkodzenia ośrodkowego układu nerwowego aż do demencji czy otępienia starczego, czy choroba Alzheimera, prowadzące do znacznych trudności z wykonywaniem czynności dnia codziennego. Również u osób starszych powszechne są zaburzenia metaboliczne, takie jak: cukrzyca, zaburzenia gospodarki lipidowej oraz upośledzenie sprawności ruchowej, wynikające ze zmian zwyrodnieniowych stawów. Zatem osoby dożywające późnej starości będą generowały rosnące wydatki na zdrowie i opiekę, a w szczególności opiekę długoterminową i opiekę terminalną, przy często niewielkich własnych możliwościach finansowania tej opieki. Spowodowane to jest zarówno stanem zdrowia, jak i wynikającą z tego koniecznością częstszego odwiedzania lekarzy zarówno podstawowej opieki zdrowotnej, jak i częstszego korzystania z porad specjalistycznych (zob. załącznik - tabele 2 i 3). Liczba wizyt u lekarza podstawowej opieki zdrowotnej wzrasta z wiekiem i w przypadku osób w wieku $70+$ jest nieomal dwukrotnie wyższa niż liczba wizyt osób młodych w 2-3 dekadzie życia. Podobna tendencja wzrostowa jest obserwowana również w przypadku wizyt u lekarzy specjalistów. Jest to niewątpliwie bardzo duże wyzwanie dla polityki socjalnej państwa, wymagające dużych zmian i nakładów finansowych, związanych z tworzeniem programów gwarantujących dostęp do specjalistycznych usług socjalnych i zdrowotnych, aktywizujących osoby starsze i propagujących zdrowe i aktywne starzenie się. Programy te powinny mieć na celu wykorzystanie potencjału, doświadczenia życiowego i zawodowego osób w wieku podeszłym i sprawienie, że życie tych 
osób stanie się społecznie i ekonomicznie użyteczne, a jednocześnie dojdzie do efektywnego zagospodarowania czasu seniorów. Konieczne są również działania wymuszające zmiany kulturowe oraz zmianę percepcji osób starszych przez społeczeństwo i potencjalnych pracodawców. Również promowane od wielu lat działania dotyczące zdrowego i aktywnego starzenia się społeczeństwa osiągają coraz bardziej wymierne efekty pod postacią dostosowanej do stanu zdrowia i utrzymującej się aktywności zawodowej i społecznej. Seniorzy w sposób coraz bardziej proaktywny dbają o swoje zdrowie, samodzielność i utrzymanie aktywności zawodowej, aby jak najdłużej cieszyć się dobrą jakością życia.

System opieki zdrowotnej i społecznej nad osobami starszymi w Polsce nie jest dostosowany do potrzeb tej populacji, ponieważ oferuje świadczenia zdezintegrowane, rozproszone i niespójne. Ponadto, system nie spełnia standardów podejścia geriatrycznego, do których należą powszechność, jakość, dostępność i kompleksowość zaspokajania wielorakich potrzeb populacji osób starych. Obecnie mamy do czynienia z taką sytuacją, że długotrwała opieka nad niedołężnymi i poważnie chorymi, często na choroby przewlekłe, osobami starszymi w Polsce spoczywa głównie na rodzinie, która w niedostatecznym stopniu jest wspomagana usługami medycznymi i pozamedycznymi systemu opiekuńczego państwa. Należy podkreślić również fakt braku przygotowania lekarzy POZ do opieki geriatrycznej oraz brak zharmonizowania opieki wysokospecjalistycznej, co jest przyczyną nieskuteczności leczenia lub pogorszenia stanu zdrowia u dużej części osób chorych w starszym wieku. Oprócz tego dyskryminacja w zakresie procedur diagnostycznych i leczniczych ze względu na wiek, ale także sposób kwalifikowania chorych do wysokospecjalistycznych procedur bez pełnej geriatrycznej analizy przeciwwskazań jest ważną przyczyną nieskuteczności leczenia lub działań niepożądanych u dużej części chorych w starszym wieku. Zdiagnozowano, że w Polsce występuje niedostateczna liczba kadry opieki geriatrycznej. Istnieje zatem nagląca potrzeba stworzenia kompleksowego systemu opieki geriatrycznej. Tymczasem specjalistyczna opieka zdrowotna uwzględniająca potrzeby ludzi starszych jest w Polsce na niezadowalającym poziomie. Świadczy o tym znikoma liczba lekarzy geriatrów i pielęgniarek ze specjalizacją w dziedzinie pielęgniarstwa geriatrycznego oraz brak placówek geriatrycznych czy szpitalnych oddziałów geriatrycznych, za co ponosi odpowiedzialność Narodowy Fundusz Zdrowia, który nisko wycenia opiekę geriatryczną. Opieka nad osobą w wieku starszym powinna być sprawowana przez wielodyscyplinarny zespół złożony z personelu medycznego, niemedycznego oraz wolontariuszy. Tak rozumiana i realizowana opieka zapewnia holistyczne spojrzenie na potrzeby osoby starszej, a tym samym umożliwia indywidualizację w zakresie świadczonych usług zdrowotnych (Karkowski, 2015, s. 82-94). 
Przeprowadzona w 2015 roku kontrola NIK wykazała niewystarczające przygotowanie polskiego systemu ochrony zdrowia do opieki nad osobami starszymi (zob. https://www.nik.gov.pl/plik/id,8319,vp,10379.pdf). Brakuje standardowych i powszechnie akceptowanych kompleksowych procedur postępowania z osobami w wieku starszym. W naszym systemie opieki zdrowotnej osoba starsza w pierwszej kolejności odwiedza lekarza podstawowej opieki zdrowotnej (POZ), który nie ma wystarczającego przygotowania w zakresie geriatrii i albo próbuje ją leczyć sam, albo wysyła pacjenta w starszym wieku do lekarza specjalisty. Traktuje zatem starszego pacjenta, jak pacjenta $\mathrm{w}$ średnim wieku, czyli wysyła go do specjalisty. Ze względu na to, że osoba w wieku podeszłym cierpi najczęściej na szereg różnych przewlekłych schorzeń, dlatego jest wysyłana do różnych specjalistów. Każdy ze specjalistów leczy pacjenta w swoim zakresie, bez uwzględnienia postawionych rozpoznań medycznych i zaordynowanych leków stosowanych w innych schorzeniach. Brak skoordynowanej opieki medycznej i farmaceutycznej dla osób w wieku podeszłym jest jedną z głównych bolączek obecnego systemu ochrony zdrowia.

Następnym problemem jest zbyt krótki i standardowy czas wizyty u lekarza specjalisty. Osoby w wieku podeszłym często mają równy stopień niepełnosprawności ruchowej, ubytki słuchu, niedowidzenie, kłopoty ze zrozumieniem czy z precyzyjnymi odpowiedziami na rutynowe pytania lekarza. Bardzo ważnym aspektem opieki nad pacjentem geriatrycznym jest nie tylko udzielenie porady medycznej czy innych świadczeń zdrowotnych, ale przede wszystkim zapewnienie pacjentom kompleksowej opieki medycznej, społecznej, pielęgnacyjnej, rehabilitacyjnej i socjalnej. W wyniku tego jakość świadczonych usług może być niewystarczająca. Wdrażana obecnie ustawa o sieci szpitali spowodowała włączenie niewielu istniejących samodzielnie oddziałów geriatrycznych do oddziału chorób wewnętrznych. Zmniejszenie bazy szpitalnych łóżek geriatrycznych ogranicza nie tylko możliwości leczenia, lecz także możliwości kształcenia wykwalifikowanej kadry medycznej, a brak stosownej wyceny procedur geriatrycznych skutecznie uniemożliwia powiększanie bazy łóżek geriatrycznych. Nadal nierozwiązanym problemem związanym z systemem ochrony zdrowia jest niewystarczające kształcenie $\mathrm{w}$ dziedzinie geriatrii na studiach medycznych. W większości polskich uczelni nie ma oddzielnych programów kształcenia poświęconych geriatrii.

Według najbardziej aktualnych danych z rejestru Naczelnej Izby Lekarskiej z 30 września 2017 roku dotyczących zestawienia liczbowego lekarzy i lekarzy dentystów według dziedziny i stopnia specjalizacji, obecnie w Polsce jest 423 lekarzy geriatrów, z czego 413 jest aktywnych zawodowo. Geriatria jest trudną specjalizacją wymagającą holistycznego spojrzenia na pacjenta oraz 
posiadania przez lekarza wiedzy z wielu innych specjalistycznych dziedzin medycyny. Równocześnie praca z trudnymi, często bardzo schorowanymi osobami o różnym stopniu sprawności, wynikającym z chorób przewlekłych, które trudno wyleczyć, a jedynie można zahamować ich postęp lub poprawić jakość życia, np. przez zmniejszenie bólu, jest bardzo frustrująca. Dlatego też ta specjalizacja jest bardzo niechętnie wybierana przez młodych lekarzy.

Koszty opieki medycznej zwiększają się wraz z wiekiem. Przeprowadzone w 2002 roku badania kanadyjskie wykazały, że w 2002 roku wydatki na opiekę zdrowotną seniora wynosiły 8208 dolarów kanadyjskich (CAD) rocznie, a wydatki na osoby poniżej 65 roku życia wynosiły $1428 \mathrm{CAD}$, natomiast w 2008 roku wzrosły one odpowiednio do: 10742 CAD i 2097 CAD. Osoby powyżej 80 roku życia kosztują system 18160 CAD per capita, co stanowi ponad trzy razy większą kwotę wydatków niż w przypadku osób w wieku 65-69 lat (zob. Myth, 2011, s. 253, 253, p. 2).

W Polsce Narodowy Fundusz Zdrowia również szacuje poziom wydatków na świadczenia zdrowotne udzielane osobom w różnym wieku. W 2014 roku przeciętne wydatki poniesione na jedną osobę wyniosły 1378 zł. Ale o ile wydatki na jedną osobę znajdującą się w przedziale wiekowym 2-40 lat przekraczały nieco $500 \mathrm{zl}$, to wraz z wiekiem rosły w coraz szybszym tempie. Nakłady ponoszone przez NFZ na opiekę zdrowotną: dla 47-letniej osoby przekroczyły w 2014 roku 1000 zł, dla 55-letniej - przekroczyły 1500 zł, dla 60-letniej - 2000 zł, dla 65-letniej - 2500 zł, dla 68-letniej - przekroczyły 3000 zł, a dla 75-letniej - 3500 zł (zob. Prognoza kosztów świadczeń opieki zdrowotnej finansowanych przez Narodowy Fundusz Zdrowia w kontekście zmian demograficznych w Polsce, 2015).

\section{Podsumowanie}

Postępujący proces starzenia się społeczeństwa jest dużym wyzwaniem, wymagającym szeroko zakrojonych i centralnie koordynowanych działań w wielu dziedzinach. Efekty tych działań będą długoterminowe i odczuwane dopiero za kilka lat. W niniejszym artykule problematyka starzenia się społeczeństwa polskiego została przedstawiona w trzech odrębnych aspektach: demograficznym, konsekwencji społeczno-ekonomicznych i zdrowia seniorów.

Analizując aspekt demograficzny należy stwierdzić, iż w kolejnych latach będzie następować ubytek liczby ludności Polski oraz zmiana struktury demograficznej. Efekty podjętych przez rząd działań typu program „Rodzina 500+”, mających na celu zachęcenie do posiadania większej liczby dzieci oraz liczne kampanie społeczne, mające na celu obniżenie średniego wieku urodze- 
nia pierwszego dziecka, zaczynają przynosić pierwsze efekty, polegające na zwiększeniu liczby dzieci i powolnym odmładzaniu populacji polskiej. Jednakże postępujące wydłużanie życia oraz zmniejszenie nadumieralności mężczyzn w stosunku do kobiet długo jeszcze nie pozwoli na widoczne efekty. Kolejne działania polegające na zachętach do powrotu z emigracji oraz otwarcie granic dla imigrantów głównie za wschodniej granicy może być szansą na szybką poprawę sytuacji.

Analizując aspekt społeczno-ekonomiczny starzenia się społeczeństwa polskiego należy mieć na uwadze często trudną sytuację materialną i konieczność zapewnienia opieki doraźnej lub opieki stałej, poczucie osamotnienia, pogarszanie się jakości życia, postępujący lęk przed śmiercią oraz związane z tym zaburzenia emocjonalne. Ważnym zadaniem jest budowanie świadomości - wśród osób bezdzietnych lub żyjących samotnie - konieczności posiadania dodatkowego ubezpieczenia lub zwiększonych oszczędności indywidualnych, które można będzie w przyszłości przeznaczyć na opiekę. Jednocześnie uruchomienie różnych programów aktywizujących seniorów mogłoby pozwolić na pełniejsze wykorzystanie potencjału osób z tej grupy wiekowej, poprawę ich sytuacji materialnej czy też zapobieganie izolacji społecznej i pogłębianiu się problemów emocjonalnych. Zapewnienie dogodnych, elastycznych i dostosowanych do możliwości seniorów warunków zatrudnienia może pozwolić również na zapełnienie luk, związanych z ubytkiem wykwalifikowanej kadry, $\mathrm{np}$. w ochronie zdrowia. Interesującym rozwiązaniem mogą być oferty zniechęcające do odchodzenia na przedwczesne emerytury.

Analizując aspekt zdrowia seniorów należy zwrócić uwagę na konieczność podjęcia natychmiastowych i długoterminowych działań ukierunkowanych na profilaktykę i wczesne wykrywanie chorób, dbałość o własne zdrowie i aktywizację osób starszych. Bardzo istotny jest problem deficytu wykwalifikowanej kadry lekarzy i personelu medycznego oraz wystarczającej liczby opiekunów medycznych. Na efekty działań w tym zakresie trzeba będzie poczekać kilka lub kilkanaście lat, ze względu na długi proces kształcenia kadry medycznej. Zapewnienie większej liczby wykwalifikowanego personelu medycznego w dziedzinie geriatrii wymaga podjęcia działań długoterminowych dotyczących systemu kształcenia pracowników służby zdrowia, podniesienia prestiżu i rangi zawodu medycznego oraz większego otwarcia na imigrację wykwalifikowanych pracowników z innych krajów. Następujące w kolejnych latach wzrosty kosztów opieki zdrowotnej będą związane nie tylko ze zwiększającymi się potrzebami zdrowotnymi i hospitalizacjami osób starszych, lecz także z postępującym wzrostem wynagrodzenia pracowników ochrony zdrowia. Bez natychmiastowego i znaczącego zaangażowania państwa w realizację i osiagnnięcie celów, uwzględ- 
niających potrzeby starzejącego się społeczeństwa, opieka nad osobami starszymi będzie niewystarczająca, a tym samym dojdzie do nadmiernego obarczenia dodatkowymi obowiązkami oraz kosztami rodzin osób starszych.

\section{Bibliografia}

Gryglewicz, J. (2017). Epidemia starości. Manager Zdrowia, 8.

http://www.who.int/kobe_centre/ageing/ahp_vol5_glossary.pdf?ua=1 (dostęp: 10.09.2017).

http://www.gazetaprawna.pl/artykuly/1016288,nie-tylko-500-plus-wplywa-na-zwiekszenie-

liczby-urodzen.html (dostęp: 10.09.2017).

https://www.nik.gov.pl/plik/id,8319,vp,10379.pdf

https://www.obserwatorfinansowy.pl/tematyka/.../najlepiej-byc-zdrowym-i-pracowity (dostęp: 10.09.2017).

Jakość życia osób starszych w Polsce na podstawie wyników Badania Spójności Spotecznej 2015. GUS, Departament Badań Społecznych i Warunków Życia. Urząd Statystyczny w Łodzi, www.stat.gov.pl

Karkowski, T. (2015). Dostosowywanie zasobów kadry medycznej do potrzeb starzejącego się społeczeństwa Zdrowie Publiczne i Zarządzanie, 13(1).

Ludność w wieku 60 lat i więcej (struktura wedtug ptci $i$ wieku, trwanie życia, umieralność, prognoza) (2016). Warszawa: GUS, Departament Badań Demograficznych i Rynku Pracy.

Matżeństwa oraz dzietność w Polsce (2016, styczeń). Warszawa: GUS, Departament Badań Demograficznych i Rynku Pracy.

Myth: The Aging Population is to Blame for Uncontrollable Health Care Costs (2011). Journal of Health Services Research \& Policy, 16(4).

OECD (2017). Preventing Ageing Unequally. Paris: OECD Publishing, http://dx.doi. org/10.1787/9789264279087-en (dostęp: 10.09.2017).

Prognoza kosztów świadczeń opieki zdrowotnej finansowanych przez Narodowy Fundusz Zdrowia w kontekście zmian demograficznych $w$ Polsce (2015, listopad). Warszawa: NFZ. Departament Analiz i Strategii, http://www.nfz.gov.pl/gfx/nfz/userfiles/_public/o_nfz/publikacje/ prognoza_kosztow_swiadczen_opieki_zdrowotnej_finansowanych_przez_nfz.pdf (dostęp: 7.12.2017).

Prognoza ludności na lata 2014-2050. (2014). Warszawa: GUS, http://stat.gov.pl/files/gfx/ portalinformacyjny/pl/defaultaktualnosci/5469/1/5/1/prognoza_ludnosci_na_lata 20142050, pdf (dostęp: 10.09.2017).

Stan zdrowia ludności Polski w 2014 r. (2016).Warszawa: GUS.

Starzenie się społeczeństwa polskiego i jego skutki (2011, kwiecień). Warszawa: Kancelaria Senatu, Biuro Analiz i Dokumentacji.

Sytuacja demograficzna osób starszych i konsekwencje starzenia się ludności Polski w świetle prognozy na lata 2014-2050. (2014, listopad). Warszawa: GUS, Departament Badań Demograficznych i Rynku Pracy.

The 2015 Ageing Report (2015). Economic and Financial Affairs Economic and Budgetary Projections for the $28 \mathrm{EU}$ Member States (2013-2060). European Economy, 3. 


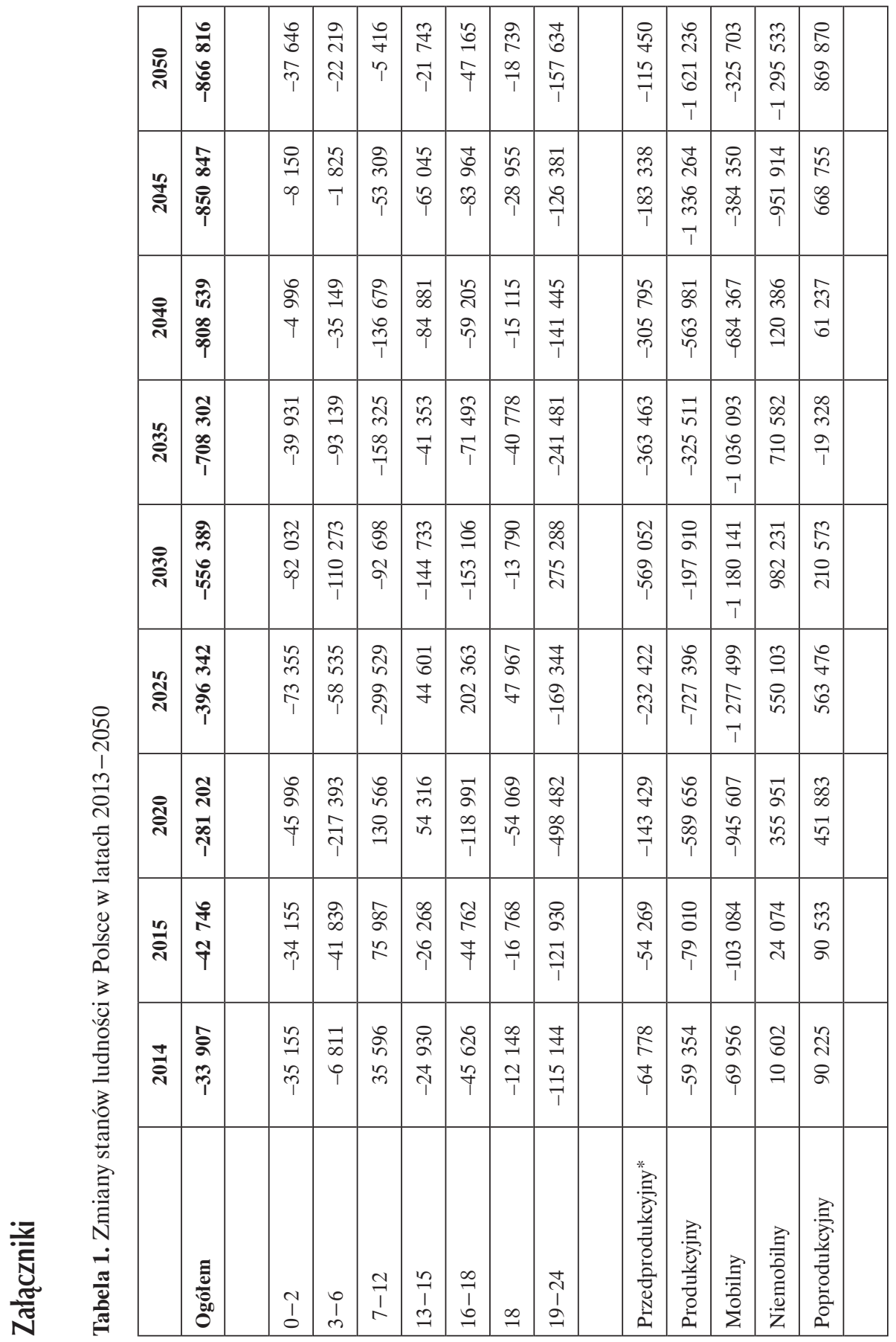




\begin{tabular}{|c|c|c|c|c|c|c|c|c|c|c|}
\hline 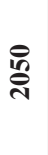 & $\begin{array}{l}\stackrel{\vec{N}}{\hat{N}} \\
\hat{\imath}\end{array}$ & $\begin{array}{l}\text { ล } \\
\text { तิ } \\
\text { กี } \\
7\end{array}$ & $\begin{array}{l}\stackrel{+}{\Xi} \\
\text { હે } \\
\stackrel{n}{n}\end{array}$ & $\begin{array}{l}\text { Uू } \\
1 \\
0 \\
0 \\
7\end{array}$ & 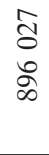 & $\begin{array}{l}\hat{n} \\
m \\
\vec{y}\end{array}$ & 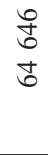 & $\begin{array}{l}\text { â } \\
\text { in } \\
\text { if }\end{array}$ & 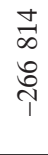 & \\
\hline 芩 & 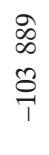 & 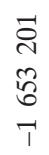 & $\begin{array}{l}\text { đa } \\
\text { \&̊ } \\
\alpha\end{array}$ & \begin{tabular}{l}
\multirow{2}{m}{} \\
$\infty$ \\
$\infty$ \\
$\cdots$ \\
$T$
\end{tabular} & 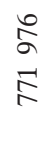 & $\begin{array}{l}\widetilde{\sigma} \\
\stackrel{+}{\infty} \\
\infty\end{array}$ & 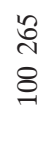 & 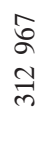 & $\begin{array}{l}\text { o } \\
\cdots \\
\stackrel{7}{+}\end{array}$ & \\
\hline 웜 & \begin{tabular}{l}
$\hat{8}$ \\
\multirow{1}{*}{} \\
\multirow{1}{*}{}
\end{tabular} & $\begin{array}{l}\stackrel{\mathcal{Y}}{+} \\
\stackrel{2}{7} \\
\stackrel{T}{T}\end{array}$ & $\begin{array}{l}\stackrel{R}{i n} \\
\text { aे } \\
\text { के }\end{array}$ & 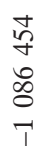 & $\begin{array}{l}\text { D } \\
\stackrel{n}{\sim} \\
\stackrel{n}{n}\end{array}$ & 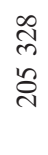 & 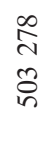 & 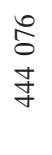 & $\begin{array}{l}\stackrel{m}{\sim} \\
\cdots \\
\infty \\
i\end{array}$ & \\
\hline గి & $\begin{array}{l}\infty \\
\dot{+} \\
o \\
\stackrel{1}{p}\end{array}$ & $\begin{array}{l}0 \\
a \\
n \\
0 \\
7 \\
1\end{array}$ & $\begin{array}{l}\tilde{\delta} \\
\widehat{\delta}\end{array}$ & $\begin{array}{l}\text { ते } \\
\text { } \\
\text { है } \\
1\end{array}$ & 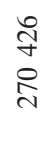 & $\begin{array}{l}\stackrel{2}{c} \\
\text { } \\
\stackrel{2}{2}\end{array}$ & $\begin{array}{l}\frac{8}{8} \\
\text { రి }\end{array}$ & $\begin{array}{l}2 \\
0 \\
\infty \\
\infty \\
\infty\end{array}$ & \begin{tabular}{l}
0 \\
๖ \\
\multirow{2}{*}{} \\
\multirow{1}{1}{}
\end{tabular} & \\
\hline ల్లి & $\begin{array}{l} \pm \\
\frac{7}{6} \\
\frac{1}{1}\end{array}$ & $\begin{array}{l}\text { gे } \\
\text { r } \\
\text { 范 }\end{array}$ & 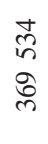 & \begin{tabular}{l}
$\infty$ \\
\multirow{2}{*}{} \\
T⿱ \\
$i$
\end{tabular} & $\begin{array}{l}8 \\
i n \\
i \\
\text { if }\end{array}$ & $\begin{array}{l}\mathbb{N} \\
\infty \\
\infty \\
\infty\end{array}$ & 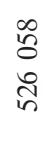 & $\begin{array}{l}\vec{m} \\
m\end{array}$ & $\begin{array}{l}0 \\
i n \\
\infty \\
i \\
1\end{array}$ & \\
\hline ^ِ̃ & $\frac{\stackrel{m}{F}}{\stackrel{m}{+}}$ & $\begin{array}{l}\text { 吕 } \\
\text { aे }\end{array}$ & $\begin{array}{l}\vec{n} \\
\stackrel{\sim}{n} \\
\stackrel{n}{n}\end{array}$ & 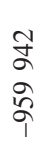 & $\begin{array}{l}\text { ले } \\
\stackrel{\alpha}{\alpha}\end{array}$ & $\begin{array}{l}\hat{\sigma} \\
i \\
i \\
\text { to }\end{array}$ & \begin{tabular}{l}
\multirow{6}{0}{} \\
+
\end{tabular} & $\begin{array}{l}\mathbb{N} \\
\hat{\sigma} \\
\end{array}$ & $\begin{array}{l}n \\
n \\
\infty \\
\infty \\
\infty\end{array}$ & \\
\hline ฮั઼ิ & $\begin{array}{l}+ \\
\text { + } \\
\text { oे } \\
\stackrel{1}{1}\end{array}$ & 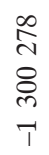 & $\begin{array}{l}8 \\
\wp \\
\infty \\
\infty \\
\infty \\
-1\end{array}$ & 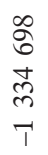 & 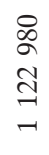 & $\begin{array}{l}\hat{D} \\
\text { d } \\
\pm\end{array}$ & $\begin{array}{l}\text { ले } \\
\text { ป }\end{array}$ & $\begin{array}{l}\sqrt{6} \\
\sigma \\
=\end{array}$ & $\begin{array}{l}\stackrel{2}{a} \\
\text { m } \\
\text { î }\end{array}$ & \\
\hline$\frac{n}{\text { ) }}$ & \begin{tabular}{l}
\multirow{2}{*}{} \\
\multirow{1}{*}{} \\
\multirow{1}{*}{}
\end{tabular} & \begin{tabular}{l}
$\stackrel{0}{6}$ \\
2 \\
\multirow{1}{1}{}
\end{tabular} & $\begin{array}{l}\text { ठ0 } \\
\infty \\
\text { ते }\end{array}$ & 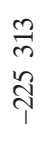 & $\begin{array}{l}\vec{\sim} \\
\text { ñ } \\
\ddot{n}\end{array}$ & $\begin{array}{l}\mathfrak{b} \\
\text { r } \\
\text { n̊ }\end{array}$ & $\begin{array}{l}\hat{m} \\
\infty \\
\infty\end{array}$ & $\begin{array}{l}m \\
i n \\
q\end{array}$ & $\begin{array}{l}\text { o } \\
\text { } \\
\text { ర్ర }\end{array}$ & 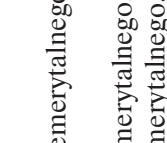 \\
\hline$\underset{\text { ন }}{\vec{\sim}}$ & $\begin{array}{l}\stackrel{2}{\alpha} \\
\stackrel{1}{1}\end{array}$ & $\begin{array}{l}\text { 寸0 } \\
\text { ڤે } \\
\text { iे }\end{array}$ & $\begin{array}{l}\stackrel{0}{7} \\
\stackrel{i}{d}\end{array}$ & 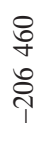 & 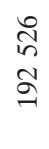 & $\begin{array}{l}\overrightarrow{\widetilde{\sigma}} \\
\text { ల }\end{array}$ & $\begin{array}{l}\mathfrak{J} \\
\infty \\
m\end{array}$ & $\begin{array}{l}0 \\
a \\
b \\
\varnothing\end{array}$ & $\begin{array}{l}2 \\
\infty \\
\infty \\
+ \\
1\end{array}$ & 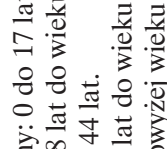 \\
\hline & $\stackrel{+}{1}$ & $\begin{array}{l}2 \\
1 \\
1 \\
n\end{array}$ & $\stackrel{1}{0}$ & $\begin{array}{l}\mathbb{J} \\
1 \\
\text { in }\end{array}$ & 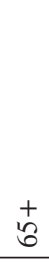 & $\stackrel{+}{\stackrel{2}{n}}$ & $\stackrel{+}{+}$ & $\begin{array}{l}+ \\
\infty \\
\infty\end{array}$ & $\begin{array}{l}a \\
1 \\
1 \\
n \\
2 \\
3 \\
0 \\
0 \\
0 \\
0\end{array}$ & 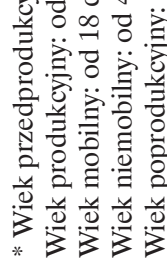 \\
\hline
\end{tabular}


Tabela 2. Osoby chodzące do lekarza ogólnego (lekarza POZ), rodzinnego lub pediatry oraz lekarza specjalisty w ostatnich 12 miesiącach według grup wieku (w odsetkach)

\begin{tabular}{|c|c|c|c|c|}
\hline \multirow[t]{2}{*}{ Wiek } & \multicolumn{2}{|c|}{$\begin{array}{c}\text { Ostatnia wizyta } \\
\text { u lekarza ogólnego (lekarza } \mathrm{POZ}) \\
\text { rodzinnego lub pediatry }\end{array}$} & \multicolumn{2}{|c|}{$\begin{array}{c}\text { Ostatnia wizyta } \\
\text { u lekarza specjalisty }\end{array}$} \\
\hline & $\begin{array}{c}\text { mniej niż } \\
6 \text { miesięcy temu }\end{array}$ & $\begin{array}{l}\text { od } 6 \text { do mniej niż } \\
12 \text { miesięcy temu }\end{array}$ & $\begin{array}{c}\text { mniej niż } \\
6 \text { miesięcy temu }\end{array}$ & $\begin{array}{l}\text { od } 6 \text { do mniej niż } \\
12 \text { miesięcy temu }\end{array}$ \\
\hline $0-4$ lata & 88,5 & 8,7 & 32,7 & 16,8 \\
\hline $5-9$ & 73,7 & 19,7 & 30,5 & 17,3 \\
\hline $10-14$ & 60,5 & 27,6 & 29,9 & 17,4 \\
\hline $15-19$ & 46,6 & 26,6 & 27,6 & 12,4 \\
\hline $20-29$ & 40,4 & 26,1 & 28,9 & 15,1 \\
\hline $30-39$ & 44,6 & 24,5 & 34,2 & 16,3 \\
\hline $40-49$ & 50,5 & 21,7 & 35,1 & 16,4 \\
\hline $50-59$ & 63,3 & 16,5 & 42,5 & 16,7 \\
\hline $60-69$ & 77,2 & 10,7 & 54,6 & 14,5 \\
\hline $70-79$ & 84,8 & 7,8 & 61,8 & 14,9 \\
\hline $\begin{array}{l}80 \text { lat } \\
\text { i więcej }\end{array}$ & 85,6 & 9,1 & 55,3 & 17,0 \\
\hline
\end{tabular}

Źródło: zestawienie własne na podstawie: Stan zdrowia ludności Polski w 2014 roku - tablice (2016). Warszawa: GUS, http://stat.gov.pl/obszary-tematyczne/zdrowie/zdrowie/stan-zdrowia-ludnosci-polski-w2014-r-,6,6.html (dostęp: 06.12.2017).

Tabela 3. Średnia liczba wizyt u lekarza POZ i specjalisty w ostatnich 4 tygodniach

\begin{tabular}{|l|c|c|c|c|}
\hline \multirow{2}{*}{ Wiek } & \multicolumn{3}{|c|}{ Średnia liczba wizyt u lekarza } \\
\cline { 2 - 5 } & $\begin{array}{c}\text { ogólnego (lekarza POZ), rodzinnego lub } \\
\text { pediatry }\end{array}$ & \multicolumn{2}{c|}{ specjalisty } \\
\cline { 2 - 5 } & $\begin{array}{c}\text { na 100 osób } \\
\text { korzystających }\end{array}$ & na 100 osób & $\begin{array}{c}\text { na 100 osób } \\
\text { korzystających }\end{array}$ & na 100 osób \\
\hline $0-4$ lata & 84 & 74 & 56 & 21 \\
\hline $5-9$ & 67 & 49 & 65 & 17 \\
\hline $10-14$ & 52 & 32 & 68 & 19 \\
\hline $15-19$ & 59 & 27 & 82 & 23 \\
\hline $20-29$ & 65 & 26 & 81 & 27 \\
\hline $30-39$ & 68 & 30 & 84 & 29 \\
\hline $40-49$ & 78 & 39 & 90 & 38 \\
\hline $50-59$ & 86 & 54 & $\mathbf{9 1}$ & 49 \\
\hline $\mathbf{6 0}-\mathbf{6 9}$ & $\mathbf{9 8}$ & 75 & $\mathbf{1 0 3}$ & 63 \\
\hline $\mathbf{7 0 - 7 9}$ & $\mathbf{1 1 3}$ & 95 & $\mathbf{9 0}$ & 49 \\
\hline $\mathbf{8 0}$ lat $\mathbf{i}$ więcej & $\mathbf{1 1 2}$ & 96 & & 19 \\
\hline
\end{tabular}

Źródło: zestawienie własne na podstawie: Stan zdrowia ludności Polski w 2014 roku (2016). Warszawa: GUS, s. 130, tabela 20, http://stat.gov.pl/obszary-tematyczne/zdrowie/zdrowie/stan-zdrowia-ludnoscipolski-w-2014-r-,6,6.html (dostęp: 06.12.2017). 



\title{
Sławomir Chomik ${ }^{1}$
}

\section{Wpływ transformacji cyfrowej na system ochrony zdrowia i opieki społecznej pacjentów kardiologicznych w Polsce}

\begin{abstract}
Streszczenie
Celem niniejszej pracy jest analiza bieżących trendów demograficznych i wpływu innowacyjnych rozwiązań technologicznych na wybrane parametry systemu ochrony zdrowia w Polsce, ze szczególnym uwzględnieniem pacjentów kardiologicznych, ze względu na wiodącą przyczynę śmiertelności w populacji. Nowe rozwiązania technologiczne, które dynamicznie pojawiają się w sektorze opieki zdrowotnej, padają na bardzo podatny grunt. Zmiany demograficzne, starzenie się społeczeństw, w tym również samych lekarzy, związana z wiekiem większa chorobowość, rosnące potrzeby populacji pacjentów, sprawiają, że coraz trudniej będzie zapewnić indywidualną opiekę medyczną każdemu świadczeniobiorcy na odpowiednio satysfakcjonującym poziomie. Przy stale rosnących oczekiwaniach i kosztach systemów ochrony zdrowia rozwiązaniem może być szersza i szybsza adopcja nowych technologii zarówno dla świadczeniodawców, jak i świadczeniobiorców. Analiza roli innowacyjnych rozwiązań technologicznych w nowym otoczeniu rynkowym jest przedmiotem tego opracowania.
\end{abstract}

Słowa kluczowe: demografia, śmiertelność, aplikacje mobilne, absencja chorobowa.

\section{An Impact of Digital Technology Transformation on the Health and Social Care System Among Cardiovascular Patients in Poland}

\begin{abstract}
The aim of this paper is to analyse current demographic trends and the impact of innovative technological solutions on selected healthcare system parameters in Poland, with particular focus on cardiology patients due to the leading cause of mortality in this population. New technological solutions that are emerging in the healthcare industry are coming in at a very good moment.
\end{abstract}

1 Sławomir Chomik - dr n. med., Praktyka Lekarska, Edukacja, Publicystyka Medyczna, ul. P.A. Hlonda 10/148, 02-972 Warszawa, e-mail: slawomir.chomik@hotmail.com. 
Ageing society, including healthcare professionals themselves, has increased morbidity among elderly patients, and growing needs and expectations of the population make it increasingly difficult for caregivers to provide individual care at a satisfactory level. With the ever-increasing expectations and costs of healthcare systems, the adoption of new technologies should be broader and faster for both healthcare providers and patients. An analysis of the role of innovative technological solutions in the new market environment is the subject of this study.

Keywords: ageing society, mortality, mobile apps, work absenteeism.

\section{Wskaźniki demograficzne}

Bieżąca sytuacja demograficzna kraju kształtuje się przede wszystkim pod wpływem zmian poszczególnych składników ruchu naturalnego, tj. urodzeń i zgonów, dodatkowo uzupełnionym o dane dotyczące migracji w badanej populacji. Sytuacja demograficzna w opisie statystycznym jest przedstawiana w postaci zestawu danych pozwalających na ocenę zmian w liczebności populacji oraz jej strukturze według płci i wieku. Według danych GUS, w końcu czerwca 2017 roku, ludność Polski liczyła 38422 tys. osób, w miastach mieszkało 60\% populacji. W ogólnej liczbie ludności kobiety stanowią około 52\%, współczynnik feminizacji wynosi 107 (w miastach - 111, na wsi - 101). W pierwszym półroczu 2017 roku zarejestrowano 200 tys. urodzeń żywych oraz 211 tys. zgonów.

Wykres 1. Piramida wieku ludności, stan na 30 czerwca 2017 roku
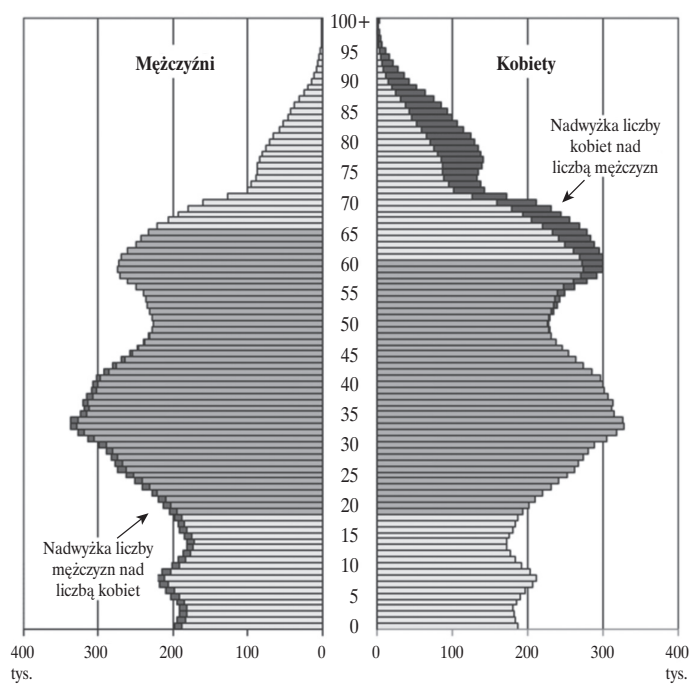

Źródło: Według raportu GUS: Ludność. Stan i struktura w przekroju terytorialnym. Stan na 30.06.2017 roku, http://stat.gov.pl/obszary-tematyczne/zdrowie/ (dostęp: 26.11.2017). 
W konsekwencji przyrost naturalny (różnica między liczbą urodzeń żywych i liczbą zgonów) był ujemny i kształtował się na poziomie -0,06\% . Wykres 1 przedstawia piramidę wieku ludności (stan na 30 czerwca 2017 roku) z wyróżnieniem populacji mężczyzn i kobiet $w$ wieku produkcyjnym. Istnieją silne wzajemne zależności między natężeniem występowania poszczególnych faktów demograficznych a strukturą ludności według płci i wieku (wykres 1). Obserwowane zmiany w strukturze wieku ludności Polski na poziomie ostatniej dekady oraz prognozowanie przyszłych zmian opartych na trendach, wskazują na istotne i coraz większe starzenie się populacji. W konsekwencji w najbliższych latach należy oczekiwać utrzymania się wzrostu liczby i natężenia zgonów związanych z wiekiem.

\section{Demografia wśród lekarzy}

Według danych Centralnego Rejestru Lekarzy RP, Naczelnej Izby Lekarskiej, z 31 grudnia 2017 roku, w Polsce jest zarejestrowanych 135486 lekarzy aktywnych zawodowo, w tym 78222 kobiet i 57264 mężczyzn. W wieku 50 r.ż. jest aż około 50\% całej populacji lekarzy aktywnych zawodowo, 31538 (23\%) mężczyzn i 39185 (29\%) kobiet. W najbliższych pięciu latach wiek emerytalny osiągnie $14990(11 \%)$ lekarzy, 6577 (5\%) mężczyzn i $8413(6 \%)$ kobiet. Obecnie 23957 (18\%) lekarzy, 10333 (7\%) mężczyzn i 13624 (10\%) kobiet, jest aktywnych zawodowo, pomimo osiągnięcia wieku emerytalnego. Szczegółowe dane aktywnych zawodowo lekarzy w podziale na grupę wiekową i płeć, przedstawia tabela 1. Dla porównania, według danych Eurostatu, we Włoszech ponad 50\% wszystkich lekarzy jest w wieku powyżej 50 r.ż., a w Niemczech w najbliższych pięciu latach $30 \%$ lekarzy osiągnie wiek emerytalny.

Tabela 1. Liczba aktywnych zawodowo lekarzy według wieku i płci na 31 grudnia 2017 roku

\begin{tabular}{|l|c|c|}
\hline \multicolumn{1}{|c|}{ Lekarze aktywni zawodowo } & Mężczyźni & Kobiety \\
\hline Wiek $26-30$ & 5255 & 9077 \\
\hline Wiek $31-35$ & 4829 & 8499 \\
\hline Wiek $36-40$ & 4144 & 6794 \\
\hline Wiek $41-45$ & 4772 & 6326 \\
\hline Wiek $46-50$ & 6700 & 8271 \\
\hline Wiek $51-55$ & 7798 & 8674 \\
\hline Wiek $56-60$ & 6830 & 8413 \\
\hline Wiek $61-65$ & 6577 & 8474 \\
\hline Wiek $66-70$ & 3963 & 5426 \\
\hline Wiek $>70$ & 6370 & 8198 \\
\hline Razem & $\mathbf{5 7 2 6 4}$ & $\mathbf{7 8 ~ 2 2 2}$ \\
\hline
\end{tabular}

Źródło: Według Centralnego Rejestru Lekarzy RP, Naczelnej Izby Lekarskiej. Liczba aktywnych zawodowo lekarzy według wieku i płci na 31.12.2017 r., http://www.nil.org.pl/rejestry/centralny-rejestr-lekarzy/ informacje-statystyczne (dostęp: 05.01.2018). 
Wśród specjalności największą populację stanowią lekarze specjaliści chorób wewnętrznych - 29068 lekarzy, następnie populacja lekarzy medycyny rodzinnej - 11114 i neurolodzy - 4302 (tabela 2). W porównaniu do innych krajów Unii Europejskiej, liczba lekarzy w Polsce jest jedną z niższych. Według danych opublikowanych w raporcie OECD Health Statistics z 2016 roku, liczba lekarzy w Polsce na 1000 mieszkańców wynosi 2,3, blisko trzykrotnie mniej niż Grecji (6,3/1000) i ponad dwukrotnie mniej niż w Austrii (5,1/1000). Średnia wartość w 28 krajach Unii Europejskiej wynosi 3,5 lekarza na 1000 mieszkańców (wykres 2).

Tabela 2. Liczba aktywnych zawodowo lekarzy specjalistów na 31 grudnia 2017 roku

\begin{tabular}{|l|c|}
\hline \multicolumn{1}{|c|}{ Specjalność } & $\begin{array}{c}\text { Liczba lekarzy aktywnych zawodowo } \\
(\mathbf{3 1 . 1 2 . 2 0 1 7}, \mathbf{N I L})\end{array}$ \\
\hline Interna & 29068 \\
\hline Medycyna Rodzinna & 11114 \\
\hline Neurologia & 4302 \\
\hline Kardiologia & 4259 \\
\hline Psychiatria & 4155 \\
\hline Pulmonologia & 2836 \\
\hline Reumatologia & 1721 \\
\hline Diabetologia & 1333 \\
\hline Gastroenterologia & 1000 \\
\hline Onkologia & 879 \\
\hline Geriatria & 417 \\
\hline
\end{tabular}

Źródło: jak w tabeli 1.

Wykres 2. Praktykujący lekarze/1000 mieszkańców w 2014 rok

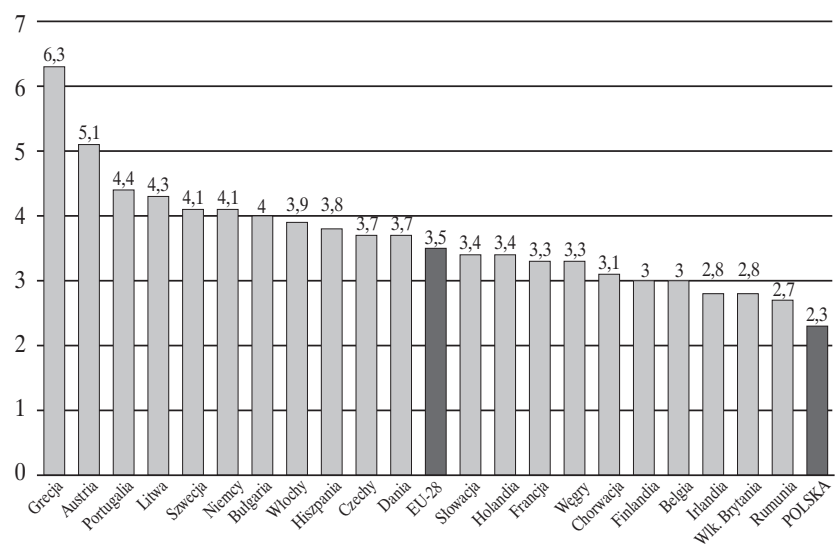

Źródło: Health at a Glance: Europe 2016, OECD 2016, Eurostat Database. 
Biorąc pod uwagę profil najczęstszych schorzeń dotykających pacjentów powyżej 50 r.ż.w tabeli 3 są przedstawione specjalności, które zajmują się schorzeniami wieku podeszłego. Dominującą rolę odgrywają tu lekarze medycyny rodzinnej, którzy odpowiadają za wczesną diagnostykę i leczenie oraz dostępność do lekarzy specjalistów, którzy odpowiadają za specjalistyczną dalszą diagnostykę oraz specjalistyczne leczenie.

Tabela 3. Najczęstsze schorzenia (Eurostat, 2017) - odpowiadające im liczba aktywnych zawodowo lekarzy specjalistów na 31 grudnia 2017 roku

\begin{tabular}{|l|l|c|}
\hline \multicolumn{1}{|c|}{$\begin{array}{c}\text { Najczęstsze przyczyny śmiertelności } \\
\text { (Eurostat, 2017) }\end{array}$} & \multicolumn{1}{c|}{ Specjalności } & $\begin{array}{c}\text { Liczba lekarzy aktywnych } \\
\text { zawodowo (31.12.2017, NIL) }\end{array}$ \\
\hline \multirow{4}{*}{ Choroby układu krążenia } & Medycyna Rodzinna & 11114 \\
\cline { 2 - 4 } & Choroby Wewnętrzne & 29068 \\
\cline { 2 - 4 } & Kardiologia & 4259 \\
\cline { 2 - 4 } & Geriatria & 417 \\
\hline \multirow{4}{*}{ Onkologia } & Chirurgia & 8947 \\
\cline { 2 - 4 } & $\begin{array}{l}\text { Chirurgia } \\
\text { Onkologiczna }\end{array}$ & 815 \\
\cline { 2 - 4 } & Onkologia & 3521 \\
\cline { 2 - 4 } & Radiologia & 770 \\
\cline { 2 - 4 } & Radioterapia & 3272 \\
\hline Choroby układu oddechowego & Choroby Płuc & 4302 \\
\hline \multirow{3}{*}{ Choroby układu nerwowego } & Neurologia & 588 \\
\cline { 2 - 4 } & Neurochirurgia & 4155 \\
\cline { 2 - 4 } & Psychiatria & \\
\hline
\end{tabular}

Źródło: jak w tabeli 1.

Według raportu GUS na koniec 2016 roku istniało w Polsce 26645 podmiotów realizujących świadczenia ambulatoryjnej opieki zdrowotnej: 21299 przychodni, 1020 praktyk lekarskich i 4326 praktyk stomatologicznych. Przeciętna liczba porad ambulatoryjnych w przeliczeniu na jednego mieszkańca w 2016 roku wyniosła 8,3 porady. Największą wartość tego wskaźnika $-8,7$ porady na jednego mieszkańca odnotowano w trzech województwach: mazowieckim, łódzkim i śląskim, a najniższą w województwie opolskim - 7,2 porady na jednego mieszkańca. 


\section{Ograniczenia systemu opieki zdrowotnej}

Starzejące się społeczeństwo i związana z tym wyższa częstość występowania chorób przewlekłych, stanowi dla systemu opieki zdrowotnej duże wyzwanie. Biorąc pod uwagę ograniczoną dostępność do lekarzy (2,3/1000 mieszkańców) w porównaniu do rosnących potrzeb społeczeństwa, konieczne wydaje się optymalne wykorzystanie dostępnych środków i struktur. Jak pokazują statystyki Eurostatu, niestety jest to jeszcze długa droga. Wykres 3 podaje liczbę zbędnych wizyt na szpitalnych izbach przyjęć, których można było uniknąć (na podstawie danych OECD Health Statistics 2016).

Wykres 3. Zbędne przyjęcia do szpitali pacjentów laboratoryjnych w 2013 roku

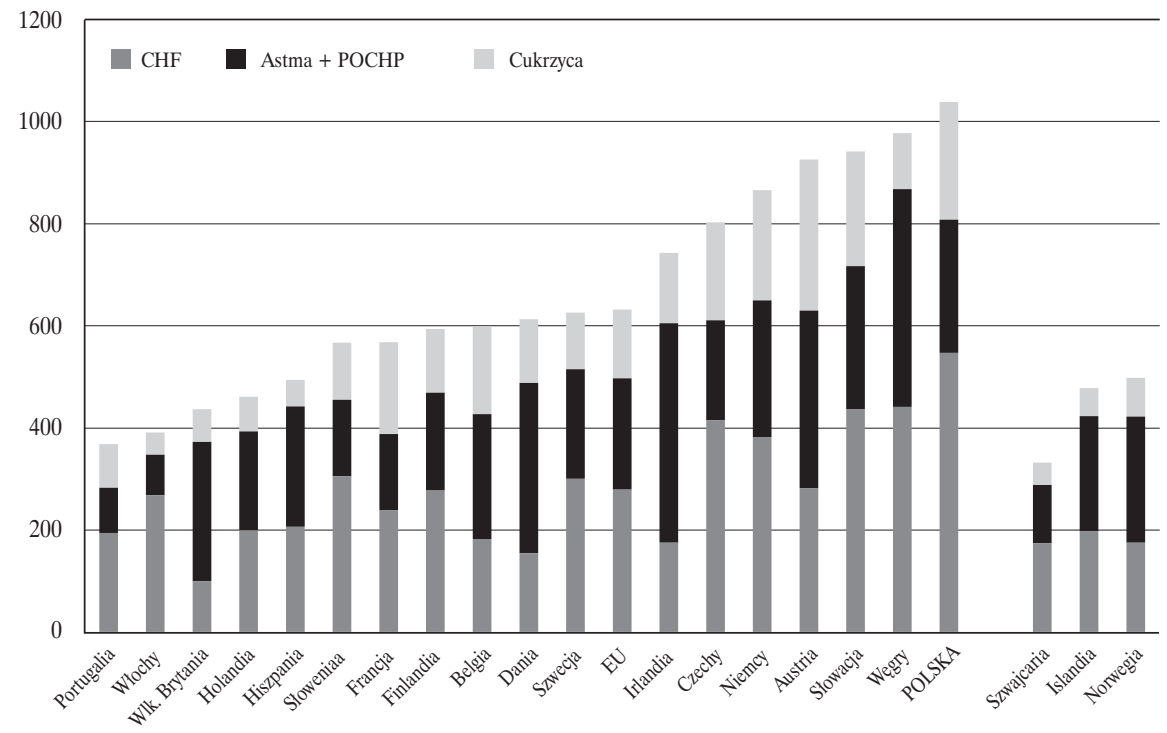

Źródło: jak w wykresie 2.

Na uwagę zwraca stosunkowo duża liczba porad u pacjentów z zastoinową niewydolnością serca (CHF) w Polsce, w porównaniu do innych krajów Unii Europejskiej. Jednym z powodów może być nadużywanie w rozpoznaniu kodów chorób, według Międzynarodowej Statystycznej Klasyfikacji Chorób i Problemów Zdrowotnych (ICD-10, rewizja dziesiąta) określanych jako tzw. kody śmieciowe. Zgodnie z WHO garbage codes (tzw. kody śmieciowe), to kody odpowiadające niedokładnym i nieścisłym opisom stanów i chorób, które uniemożliwiają precyzyjne określenie przyczyny zgonu. Przyjmuje się, że 
w przypadku orzeczeń dla zgonów w wyniku chorób układu krążenia, rozpoznania „śmieciowe” stanowią nawet 50\% (GUS, 2017).

Warto zauważyć, że występowanie niewydolności serca rośnie dynamicznie wraz z wiekiem, od mniej niż $1 \%$ w populacji do 50 r.ż. do ponad $10 \%$ u osób w wieku 70-80 lat i starszych. Już teraz kobiety stanowią większość pacjentów z niewydolnością serca, a biorąc pod uwagę ich dłuższą przeżywalność w stosunku do mężczyzn, dysproporcje te z czasem będą ulegać dalszemu rozwarstwieniu (Chomik, Hoffman, 2016).

Dwa dominujące, najczęściej używane przez lekarzy kody śmieciowe z zakresu chorób układy krążenia (ChUK), to niewydolność serca oznaczone jako I-50 według ICD-10 (opis dotyczył 38 tys. zgonów w 2013 roku, co stanowiło około $46 \%$ kodów śmieciowych z zakresu chorób układu krążenia) oraz uogólniona i nieokreślona miażdżyca. Co ciekawe, blisko dwukrotny wzrost śmiertelności z powodu niewydolności serca, oznaczony kodem śmieciowym I-50, utrzymuje się od 2010 roku (30 tys. przypadków), w 2013 roku rozpoznanie to postawiono w przypadku 34 tys. zgonów, do tego czasu liczba zgonów z powodu niewydolności serca (ICD-10: I-50) była na poziomie 18 tys. (lata 2000-2005).

Na uwagę zasługuje fakt, że aż $87 \%$ rozpoznań śmieciowych w zakresie ChUK, dotyczy zgonów osób w wieku 65 lat i więcej. Mimo że populacja osób powyżej 60 roku życia stanowi około $25 \%$ całości populacji UE, to odpowiada ona za $60 \%$ całkowitych kosztów opieki zdrowotnej w Europie. Przewiduje się, że populacja osób w wieku powyżej 60 roku życia w Europie osiągnie 35\% w 2050 roku i 36\% w 2100 roku (United Nations, 2017). Do 2050 roku autorzy raportu UN przewidują, że populacja 51 krajów na świecie, w tym Polski, zmniejszy się o ponad $15 \%$.

W Polsce odsetek wszystkich rozpoznań śmieciowych, nie tylko kardiologicznych, wyniósł blisko 30\% w 2013 roku. Dla porównania odsetek wszystkich rozpoznań śmieciowych w krajach sąsiednich w 2013 roku kształtował się na poziomie $15 \%$ w Czechach, $14 \%$ w Niemczech, $11 \%$ na Słowacji i Łotwie oraz 6-7\% na Litwie i Węgrzech. Wielu z tych wizyt można by uniknąć, gdyby dostępność do porady/konsultacji była nie tylko bardziej powszechna, ale i bardziej precyzyjna. Odpowiednia jakość i kompletność danych o przyczynach zgonów jest nie do przecenienia w świetle wykorzystania ich do badań i analiz prowadzonych w zakresie planowania i wdrażania procedur profilaktycznych na poziomie systemowym.

Przykładowa konstrukcja druku zaświadczenia lekarskiego umożliwia dzisiaj tylko określenie jednostki chorobowej według Międzynarodowej Statystycznej Klasyfikacji Chorób i Problemów Zdrowotnych (ICD-10) na III poziomie 
szczegółowości, np. I50, co uniemożliwia bardziej precyzyjne określenie jednostki chorobowej (na V poziomie szczegółowości), np. I50.0 - Niewydolność serca zastoinowa, I50.1 - Niewydolność serca lewokomorowa, czy I50.9 - Niewydolność serca nieokreślona. Przez to analizowane dane mogą być niedoszacowane lub przeszacowane.

Podsumowując, uregulowanie systemu kodyfikującego rozpoznania, w tym podniesienie jakości interwencji, najlepiej na każdym szczeblu, od poziomu lekarza rodzinnego, aż do poziomu lekarza specjalisty, racjonalne korzystanie z dostępnych zasobów przy diagnozowaniu i leczeniu pacjentów - poprzez standaryzację postępowania, jest we wspólnym interesie wszystkich interesariuszy systemu ochrony zdrowia. Optymalizacja wykorzystania dostępnej struktury opieki zdrowotnej w naszym kraju w celu poprawy zdrowia populacji ma wiele wymiarów:

- Dla świadczeniobiorców (pacjentów) i ich rodzin - gdyż będzie skutkować szybszym dostępem do profesjonalnej porady/właściwego lekarza, dalej szybszą, właściwą diagnozą, w konsekwencji szybszym wdrożeniem adekwatnego leczenia, co w końcu oznacza dla pacjenta szybszy powrót do zdrowia.

- Świadczeniodawców - racjonalizacja kosztów związanych z procesem diagnostycznym, leczniczym i rehabilitacyjnym.

- Płatnika (NFZ) - racjonalizacja budżetu przeznaczonego na świadczenia zdrowotne dla społeczeństwa.

- Płatnika (ZUS) - szybsza właściwa diagnoza i adekwatne leczenie wpłynie na krótszą absencję chorobową i szybszy powrót do pracy.

- Regulatora (Ministerstwo Zdrowia) - optymalizacja funkcjonowania systemu opieki zdrowotnej w oparciu o istniejące zasoby, pozwoli na nowe inwestycje w nowe technologie i innowacyjne rozwiązania.

- Producentów leków i urządzeń medycznych, gdyż lepsza współpraca z pozostałymi interesariuszami pozwoli uzyskać lepszy zwrot z inwestycji i w konsekwencji umożliwi szersze nakłady na nowe innowacyjne technologie.

\section{Najczęstsza przyczyna umieralności - z powodu chorób układu krążenia}

Choroby układy krążenia (ChUK) od wielu lat są zdecydowanie najczęstszą przyczyną umieralności w krajach Unii Europejskiej i w Polsce. W 2014 roku standaryzowany współczynnik umieralności z powodu choroby niedokrwiennej serca w UE-28 wynosił 126 zgonów na 100000 mieszkańców (tabela 4). 
Tabela 4. Standaryzowane współczynniki zgonów z powodu ChUK i CNd w krajach Unii Europejskiej w 2013 roku

\begin{tabular}{|c|c|c|}
\hline Państwa & $\begin{array}{l}\text { Choroby Układu Krążenia } \\
\text { (ChUK) }\end{array}$ & $\begin{array}{c}\text { Choroba Niedokrwienna Serca } \\
\text { (ChNS) }\end{array}$ \\
\hline Bulgaria & 1131 & 195 \\
\hline Rumunia & 951 & 320 \\
\hline Łotwa & 883 & 443 \\
\hline Litwa & 849 & 564 \\
\hline Węgry & 761 & 391 \\
\hline Estonia & 700 & 295 \\
\hline Chorwacja & 678 & 306 \\
\hline Słowacja & 655 & 389 \\
\hline Czechy & 615 & 333 \\
\hline POLSKA & 591 & 129 \\
\hline Słowenia & 451 & 102 \\
\hline Austria & 418 & 179 \\
\hline Niemcy & 403 & 143 \\
\hline Grecja & 381 & 103 \\
\hline UE-28 & 376 & 126 \\
\hline Szwecja & 338 & 131 \\
\hline Irlandia & 310 & 147 \\
\hline Włochy & 310 & 98 \\
\hline Portugalia & 305 & 69 \\
\hline Belgia & 282 & 72 \\
\hline Holandia & 271 & 62 \\
\hline Wielka Brytania & 265 & 118 \\
\hline Dania & 256 & 81 \\
\hline Hiszpania & 245 & 68 \\
\hline Francja & 203 & 49 \\
\hline
\end{tabular}

Źródło: jak w wykresie 2.

Do chorób układu krążenia (ChUK) zaliczają się schorzenia związane z nadciśnieniem tętniczym, wysokim poziomem cholesterolu, cukrzycą i nikotynizmem; najczęstszymi przyczynami zgonu w wyniku schorzeń układu krążenia są choroba niedokrwienna serca, w tym zawał serca, który odpowiada za 13\% śmiertelność i choroby naczyniowo-mózgowe, które odpowiadają za 9\% przyczyn zgonów.

W 2014 roku choroba niedokrwienna serca była przyczyną 126 zgonów na 100000 mieszkańców w UE-28. Państwami członkowskimi UE o najwyższym 
standaryzowanym współczynniku umieralności na chorobę niedokrwienną serca były: Litwa, Łotwa, Węgry i Słowacja - w każdym z tych krajów odnotowano ponad 350 zgonów na 100000 mieszkańców w 2014 roku. Na drugim końcu skali znalazły się: Francja, Holandia, Hiszpania, Portugalia, Belgia, Dania i Włochy. Państwa te miały najniższe standaryzowane współczynniki umieralności z powodu choroby niedokrwiennej serca - poniżej 100 zgonów na 100000 mieszkańców w 2014 roku; podobna sytuacja miała miejsce w Norwegii i Szwajcarii.

Zgony z powodu choroby niedokrwiennej serca i udarów mózgu stanowiły blisko $60 \%$ wszystkich przyczyn zgonów z powodów kardiologicznych.

W 2013 roku zgony z wszystkich przyczyn kardiologicznych stanowity blisko $40 \%$ wszystkich zgonów, z czego odpowiednio u mężczyzn stanowiły $34 \%$ wszystkich zgonów i $41 \%$ u kobiet.

Kolejną najczęstszą przyczyną umieralności były nowotwory, które stanowiły przyczynę śmierci u 30\% mężczyzn i 24\% u kobiet.

Pod względem częstości zgonów z powodu ChUK pomiędzy krajami członkowskimi UE występuje duże zróżnicowanie, z jednej strony w pięciu krajach choroby te były przyczyną ponad 50\% ogólnej liczby zgonów (Litwa, Lotwa, Estonia, Rumunia, Bułgaria), z drugiej strony w takich krajach, jak: Francja, Dania, Holandia, Wielka Brytania czy Belgia, wskaźniki te nie przekroczyły $30 \%$. W Polsce odsetek ten wynosił odpowiednio 46\% (wykres 4).

Wykres 4. Śmiertelność z powodu choroby niedokrwiennej serca w 2013 roku (100 tys. mieszkańców)

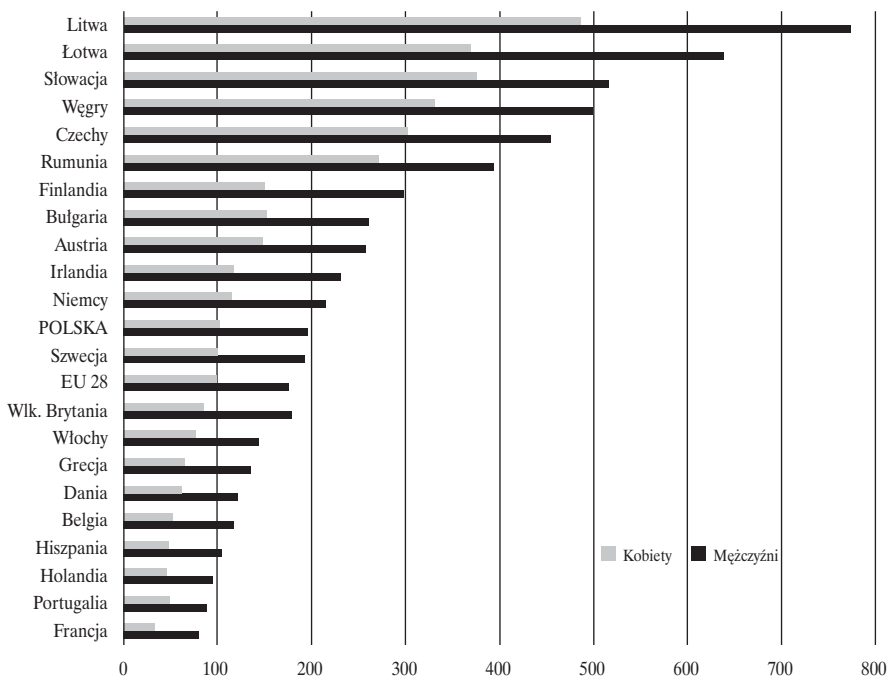

Źródło: jak w wykresie 2. 
W przypadku chorób naczyń mózgowych, w tym udarów, różnice między krajami Unii Europejskiej są jeszcze bardziej wyraziste. W Bułgarii, Rumunii i na Łotwie śmiertelność z powodu udarów mózgu była u mężczyzn ponad 5-krotnie wyższa niż we Francji czy Hiszpanii. Dla Polski wartości te są bliskie średniej europejskiej i wynoszą odpowiednio u mężczyzn 130/100 tys. mieszkańców i u kobiet 102/100 tys. mieszkańców (wykres 5). W przypadku Estonii wskaźniki dramatycznie się poprawily po tym, jak zmieniono praktyki rejestrujące zgony z udaru na nadciśnienie tętnicze (Denissov, 2016, s. 335-337).

Wykres 5. Śmiertelność z powodu udaru mózgu w 2013 roku

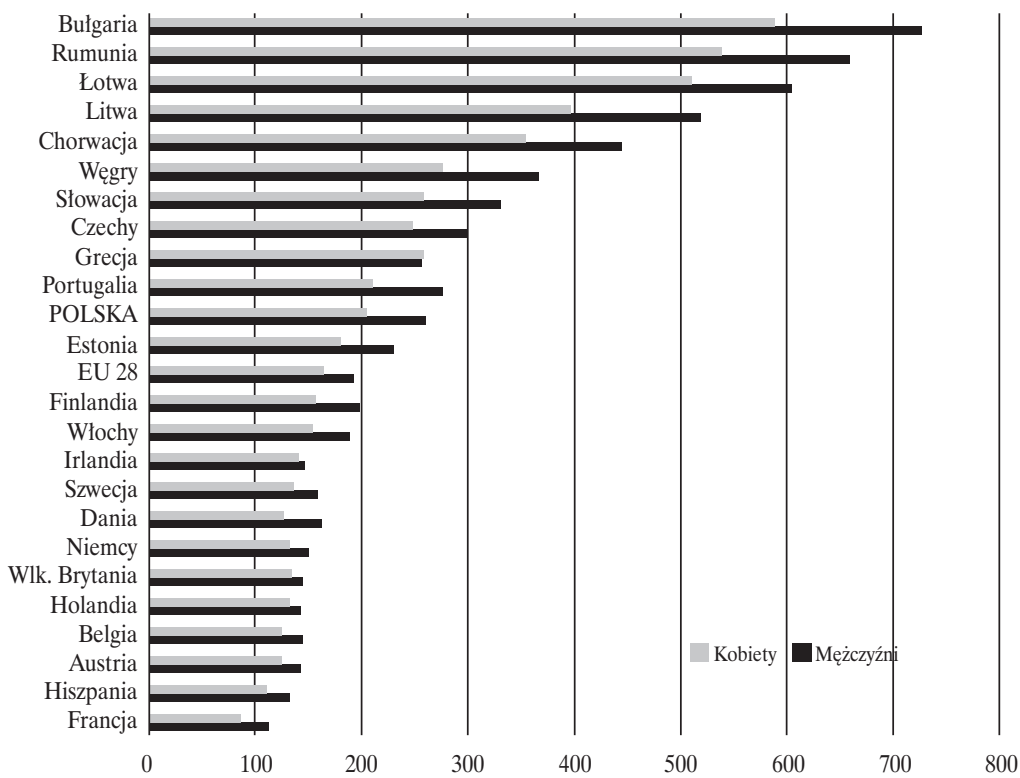

Źródło: jak w wykresie 2.

Obserwowany stopniowy spadek śmiertelności z powodu udarów naczyń mózgowych czy z powodu choroby niedokrwiennej serca, może być przypisany większej skuteczności i intensywności leczenia oraz przynajmniej częściowo, redukcji niektórych czynników ryzyka (OECD, 2015).

Jednocześnie, pomimo postępów w leczeniu schorzeń przewlekłych i stopniowej poprawy dostępności opieki zdrowotnej, a także rosnącej świadomości i prozdrowotnych zachowań w społeczeństwie oraz mimo istotnej redukcji wpływu niektórych czynników ryzyka, takich jak nikotynizm, jesteśmy świadkami rosnącej liczby młodych pacjentów z nadwagą i otyłością (zob. wykres 6). 
Wykres 6. Poziom otyłości - samoocena - dorośli w 2014 roku (\% populacji > 15 r.ż.)

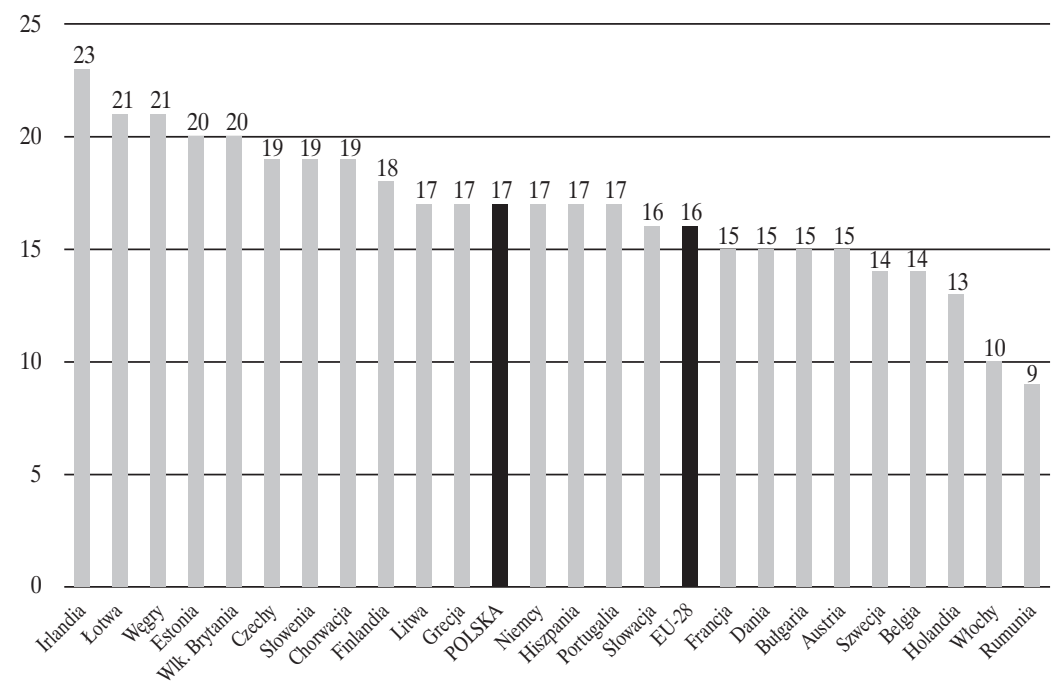

Źródło: jak w wykresie 2.

Z otyłością są związane inne choroby towarzyszące, takie jak choroby układu sercowo-naczyniowego, cukrzyca typu 2, schorzenia układu ruchu oraz schorzenia układu oddechowego. Biorąc powyższe pod uwagę, należy oczekiwać dalszego wzrostu chorobowości i związanej z nią śmiertelności w społeczeństwie (GUS, 2014).

Rozwiązanie tego kompleksowego wyzwania, wymaga działań na wielu polach i z użyciem wielu narzędzi komunikacyjnych.

Podsumowując, należy się spodziewać, że choroby układu krążenia będą nadal stanowić wiodąca przyczynę umieralności w krajach Unii Europejskiej iw Polsce.

Jednym z najważniejszych czynników, który jest związany z większą śmiertelnością, jest czynnik demograficzny. Rosnąca populacja pacjentów powyżej 65 roku życia oznacza większą ekspozycję na choroby przewlekłe, a co za tym idzie większą śmiertelność.

\section{Koszty bezpośrednie i koszty pośrednie}

Pomimo tego, że niewydolność serca jest chorobą osób starszych, obserwuje się rosnące obciążenie tą chorobą także w grupach wiekowych aktywnych zawodowo. Skutkuje to tym, że niewydolność serca nabiera coraz większego 
znaczenia ekonomicznego. Straty gospodarcze związane z absencją i zmniejszoną produktywnością chorych, a także długotrwałą niezdolnością do pracy i zgonami tych osób są szczególnie istotne również w kontekście rosnących niedoborów pracowników w Polsce. W celu zmierzenia pełnego wpływu choroby na pacjenta oraz na płatnika, jakim jest budżet państwa, konieczna jest, oprócz zmierzenia kosztów leczenia i hospitalizacji (kosztów bezpośrednich), również ocena utraty produkcji spowodowanej chorobą (koszty pośrednie) oraz wydatków na świadczenia dla osób chorych (Raport EY, 2013).

Według Raportu sporządzonego przez Instytut Innowacyjna Gospodarka w 2017 roku w Polsce niewydolność serca dotyczy około 600-700 tys. osób i ma tendencję rosnącą. Odpowiada za około 60 tys. zgonów rocznie. Tylko połowa chorych powyżej 50. r.ż. przeżywa cztery lata. Blisko $77 \%$ chorych w wieku produkcyjnym nie jest aktywnych zawodowo.

Według danych NFZ na terapię i opiekę nad pacjentami (koszty bezpośrednie), z rozpoznaniem niewydolności serca (ICD-10: I50), w 2016 roku wydano 900,3 mln zł, co stanowi ponad 9\% wzrost w porównaniu do 2015 roku. Aż za 90\% tych kosztów odpowiadały koszty hospitalizacji. Ponadto, koszty pośrednie wynikające $\mathrm{z}$ utraty produkcji spowodowanej chorobą sięgnęły, według autorów Raportu Instytutu Innowacyjna Gospodarka z 2017 roku, kwoty 3,9 mld zł w 2015 roku. Należy nadmienić, że jest to pierwsze tego typu opracowanie dotyczące kosztów pośrednich niewydolności serca na polskim rynku. Zmierzona struktura kosztów pośrednich niewydolności serca, przedstawiała się następująco:

- przedwczesne zgony: (62\%) 2,4 mld zł, wzrost o $13 \%$ v.s. 2014;

- prezenteizm, definiowany jako obniżona produktywność osób chorych obecnych w pracy: (21\%) 816,1 mln zł, wzrost o 1,9\% v.s. 2014;

- trwała niezdolność do pracy: (13\%) 497,2 mln zł, wzrost o 2,7\% v.s. 2014;

- absenteizm, definiowany jako nieobecność osób chorych w pracy: (4\%) 155,2 mln zł, co stanowiło wzrost o 9\% v.s. 2014.

Według danych zawartych w raporcie ZUS 2016, analiza liczby absencji chorobowej z tytułu choroby własnej osób ubezpieczonych w ZUS, wykonana na podstawie zaświadczeń lekarskich wydanych w formie pisemnej oraz od 1 stycznia 2016 roku wystawionych również w formie dokumentu elektronicznego e-ZLA zarejestrowanych w Rejestrze zaświadczeń lekarskich KSI ZUS, wykazała, że najczęściej występującymi przyczynami absencji w 2016 roku były:

- ciąża, poród i połóg (19,1\% ogółu liczby dni absencji chorobowej),

- choroby układu kostno-stawowego, mięśniowego i tkanki łącznej (15,3\%), 
- urazy, zatrucia i inne określone skutki działania czynników zewnętrznych $(13,9 \%)$,

- choroby układu oddechowego (12,3\%),

- choroby układu nerwowego $(8,4 \%)$,

- zaburzenia psychiczne i zaburzenia zachowania (7,9\%),

- choroby układy sercowo-naczyniowego (5\%).

O ile choroby układu krążenia nie stanowią znaczącego odsetka w grupie najczęstszych przyczyn absencji chorobowej, o tyle sytuacja ta wygląda inaczej w grupie wiekowej 60-64, gdzie choroby układu krążenia stanowią drugą $(13,6 \%)$ najczęstszą przyczynę absencji chorobowej (po chorobach układu kostno-stawowego - 23\%).

Absencja chorobowa związana z pobytem w szpitalu stanowiła ogółem 3,6\% ogólnej absencji chorobowej. Najczęściej pobyt w szpitalu był związany z:

- zaburzeniami psychicznymi i zaburzeniami zachowania - 18,5\% liczby dni pobytu w szpitalu,

- chorobami układu kostno-stawowego, mięśniowego i tkanki łącznej $-10,7 \%$,

- nowotworami $-10,3 \%$ oraz

- chorobami układu krążenia - 10,2\%.

Istnieje istotna różnica we wskaźnikach absencji między kobietami a mężczyznami. W grupach wiekowych $20-29$ oraz $30-39$, ponad dwukrotnie częściej absencja chorobowa dotyczyła kobiet, z powodu ciąży, porodu i połogu. W grupach wiekowych 40-49 i 50-59 z kolei obserwowano blisko dwukrotną przewagę mężczyzn.

Z danych ZUS wynika, że w 2015 roku na zwolnieniach lekarskich Polacy przebywali 266 milionów dni, co wygenerowało koszty blisko $17 \mathrm{mld}$ zł. W 2016 roku absencja chorobowa wyniosła już 276 milionów dni, a więc jej koszty przekroczyły kwotę 17 mld zł.

Odpowiednie działania ograniczające absencję chorobową, lub idąc dalej promujące pro-zdrowotne zachowania pracowników, mogą przynieść nie tylko wielomiliardowe oszczędności dla samych firm, ale również wpłynąć pozytywnie na dalszy rozwój ekonomiczny spółek.

Jednym z przykładów działań ograniczających absencję chorobową w pracy, są działania oparte na profilaktyce, podnoszące i wzmacniające prozdrowotne zachowania pracowników. W większości przypadków możliwe jest zaadresowanie głównych czynników wpływających na zdrowie jednostki, tzw. modyfikowalnych, takich jak działania prozdrowotne (wellness): 
- zdrowe odżywianie: (zdrowe jedzenie w kantynach, spotkania z dietetykiem, zdrowe opcje w automatach z żywnością i napojami, zdrowe opcje podczas szkoleń firmowych i imprez, promocja zdrowego odżywiania w mediach, skierowanych do pracowników, aplikacje na smartfony ułatwiające wybór zdrowej żywności);

- uprawianie sportu (finansowanie grup sportowych, promocja aktywności sportowej - zakładanie nowych grup, rozgłaszanie sukcesów sportowych, pikniki rodzinne z elementami sportowymi, aplikacje mobilne pomagające w regularnym uprawianiu sportu, połączone z sensorami mierzącymi tętno);

- rzucenie palenia (miejsce pracy wolne od tytoniu, seminaria, dzień bez papierosa, pomoc psychologiczna, aplikacja mobilna wykorzystująca elementy współzawodnictwa [rywalizacji]);

- zwalczanie stresu w pracy (seminaria, szkolenia, ulotki, bezpłatne wsparcie psychologiczne 24 godziny na dobę w postaci portalu internetowego, aplikacji mobilnej);

- profilaktyka zdrowotna (indywidualne programy ustawione przez dietetyka, badania profilaktyczne, oddawanie krwi na terenie zakładu, seminaria, szkolenia, pokazy, portal medyczny, aplikacje mobilne, strony internetowe zawierające gotowe zestawy dietetyczne, kalkulatory kalorii itd.).

Powyższe pięć kategorii działań pokrywa się z listą modyfikowalnych czynników w prewencji choroby niedokrwiennej serca, zalecanych przez Polskie Towarzystwo Kardiologiczne (PTK):

- zaprzestanie palenia tytoniu;

- obniżenie stężenia cholesterolu LDL w prewencji pierwotnej poniżej $130 \mathrm{mg} / \mathrm{dl}$, w prewencji wtórnej poniżej $100 \mathrm{mg} / \mathrm{dl}$;

- podwyższenie poziomu cholesterolu HDL powyżej $35 \mathrm{mg} / \mathrm{dl}$ u mężczyzn i $40 \mathrm{mg} / \mathrm{dl} \mathrm{u}$ kobiet;

- adekwatna kontrola ciśnienia tętniczego krwi - wartości optymalne 120/80 mm Hg;

- adekwatna kontrola poziomu glukozy we krwi poprzez odpowiednie postępowanie w razie występowania cukrzycy lub innych zaburzeń tolerancji glukozy;

- ograniczenie spożycia alkoholu;

- zwiększona aktywność fizyczna, która powoduje obniżenie stężenia cholesterolu LDL i wzrost HDL;

- obniżenie poziomu trójglicerydów poniżej $150 \mathrm{mg} / \mathrm{dl}$;

- leczenie nadwagi lub otyłości w celu przywrócenia optymalnego BMI w zakresie $20-25 \mathrm{~kg} / \mathrm{m}^{2}$. 
Większość z powyższych działań prozdrowotnych można znacząco wesprzeć, wykorzystując nowoczesne technologie oparte o mobilne aplikacje na smartfony, portale internetowe oraz niewielkie, przenośne urządzenia elektroniczne - smartbandy (smartbandy firm: Xiaomi Mi Band 2, Acer Liquid Leap, Garett Fitness, Beurer AS 81, TomTom Fitness Touch L, Fitbit Alta, Fitbit Charge 2, Huawei Talkband B3 Active, Samsung Gear Fit 2, Garmin Vivosmart HR+), badające podstawowe parametry biometryczne typu: liczba wykonanych kroków, ilość spalonych kalorii, częstość tętna, utlenowanie krwi, kalkulatory dietetyczne oraz wagę).

Dzięki swojej interaktywności, nie tylko są one źródłem informacji biometrycznej dla użytkownika, lecz także spełniają rolę aktywnych komunikatorów, zwiększających motywację do podejmowania zadań oraz oferują możliwość działań zespołowych poprzez budowanie społeczności użytkowników i wykorzystywanie dynamiki grupy.

\section{Innowacyjne rozwiązania w technologii cyfrowej}

Dynamika rozwoju innowacyjnych technologii cyfrowych wyznacza nową jakość w dotychczasowych procesach zarządzania systemu opieki zdrowotnej. Choć wdrażanie nowych rozwiązań wiąże się ze stosunkowo wysokimi kosztami, to jednak oczekiwania społeczne są na tyle wysokie, że zarządzający budżetami jednostek opieki zdrowotnej muszą je uwzględniać w planach inwestycyjnych.

Biorąc pod uwagę trendy występujące w ogólnej populacji, mamy do czynienia z dynamiką zmian, która zasadniczo wpływa na sposób, w jaki się obecnie komunikujemy, co diametralnie przekształca znane nam, dotychczasowe otoczenie rynkowe. Wiodącym przykładem jest fenomen mediów socjalnych: facebook, twitter, instagram czy WhatsApp, które skutecznie wyparły tradycyjne formy przekazu, jakimi są codzienna prasa i telewizja. Znajduje to odzwierciedlenie w aktualnych modelach komercyjnych opartych o segmentację i pozycjonowanie produktów w zależności od odpowiednio sprofilowanego odbiorcy. Bankowość internetowa w odpowiedzi na nowe potrzeby klientów zmieniła strukturę oddziałów bankowych i obecnie głównie zajmuje się doradztwem inwestycyjnym i kredytami. Podobnie sukces sprzedaży internetowej produktów FMCG, zmienił wielkie centra handlowe w centra rozrywki, gdyż zakupy towarowe są robione $\mathrm{w}$ dużej części w środowisku wirtualnym. W dziedzinie ochrony zdrowia, procesy adopcji nowych technologii wymagają nieco więcej czasu, co jest zrozumiałe, jeśli weźmiemy pod uwagę specyficzne uwarunkowania, związane z rodzajem przetwarzanych informacji i danych. 


\section{Ochrona danych osobowych w świetle nowych wytycznych (RODO)}

$\mathrm{Z}$ zagadnieniem tym wiąże się pojęcie danych wrażliwych, tj. danych ujawniających pochodzenie rasowe lub etniczne, poglądy polityczne, przekonania religijne, światopogląd oraz dane o stanie zdrowia, kodzie genetycznym, nałogach, życiu seksualnym, a także dane dotyczące skazań, orzeczeń o ukaraniu i mandatów karnych. Przetwarzanie danych osobowych wrażliwych jest wtedy legalne, gdy osoba, której te dane dotyczą, wyrazi na to pisemną zgodę (Ustawa o ochronie danych osobowych).

Od 25 maja 2018 roku definicja danych wrażliwych uległa zmianie. Rozporządzenie Parlamentu Europejskiego i Rady (UE) 2016/679 z dnia 27 kwietnia 2016 roku w sprawie ochrony osób fizycznych w związku z przetwarzaniem danych osobowych i w sprawie swobodnego przepływu takich danych oraz uchylenia dyrektywy 95/46/WE (ogólne rozporządzenie o ochronie danych - RODO), które zastępuje przepisy dotychczasowej polskiej ustawy o ochronie danych osobowych, wprowadza definicje tzw. szczególnych kategorii danych osobowych. Wśród nich uwzględniono dane o stanie zdrowia, dane ujawniające pochodzenie rasowe lub etniczne, poglądy polityczne, przekonania religijne, światopogląd, przynależność do związków zawodowych, dane genetyczne, dane biometryczne, obejmujące głos, odciski palców, grupę krwi, a także dane dotyczące seksualności oraz orientacji seksualnej. Co do zasady, przetwarzanie tych danych, zgodnie z projektem rozporządzenia, będzie zakazane, z wyjątkiem uzyskania wyraźnej, pisemnej zgody od osoby, której dane te dotyczą oraz w przypadku dochodzenia praw lub roszczeń we właściwych postępowaniach, a także w przypadku ochrony żywotnych interesów osoby, której dane te dotyczą, np. w przypadku udzielania jej pomocy medycznej.

RODO wprowadza pełną odpowiedzialność firm przetwarzających dane osobowe pochodzące $\mathrm{z}$ innych firm, włącznie z karą finansową, wprowadza obowiązek zgłaszania przez administratorów przypadków naruszeń, które mogą skutkować zagrożeniem praw i swobód osób, których dane zostały naruszone, w ciagu 72 godzin. Wprowadzono nowe, rozszerzone prawo obywateli do „bycia zapomnianym”, tj. prawo do usunięcia ich danych osobowych z rejestrów, co może mieć niebagatelne znaczenie dla firm wykorzystujących w swoich serwisach analizę danych użytkowników. Jeszcze większe znaczenie ma przepis limitujący tzw. profilowanie osób, włączając w to obowiązek otrzymania zgody na profilowanie przed rozpoczęciem zbierania danych, surowy obowiązek informowania o profilowaniu oraz konieczność akceptacji braku zgody na profilowanie. 
Nowe przepisy zostały przyjęte $\mathrm{w}$ formie rozporządzenia, co oznacza bezpośrednie stosowanie przepisów przez wszystkich przedsiębiorców przetwarzających dane na terytorium Unii Europejskiej. Z tego też powodu wejście w życie rozporządzenia nie wymaga konieczności implementacji polską ustawą. Wszystko to w celu ujednolicenia ochrony danych osobowych w Unii Europejskiej.

Działania legislacyjne na poziomie unijnym są reakcją na pilną potrzebę uregulowania rynku bezpieczeństwa danych osobowych, związanych z dynamicznym rozwojem nowych technologii i rosnącym ryzykiem zagrożenia bezpieczeństwa danych osobowych użytkowników.

\section{Innowacja w komunikacji cyfrowej - w kierunku e-medycyny i m-medycyny}

Dynamikę postępu technologicznego w dziedzinie komunikacji cyfrowej odzwierciedlają standardowe wskaźniki, dla populacji Polski przedstawione w tabeli 5 .

Tabela 5. Wskaźniki dostępu i użytkowania Internetu

\begin{tabular}{|c|c|c|c|c|c|c|c|}
\hline 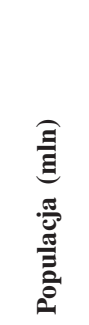 & 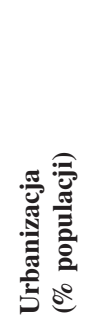 & 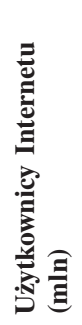 & 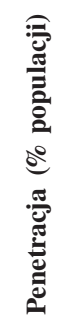 & 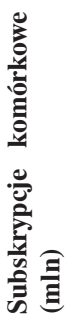 & 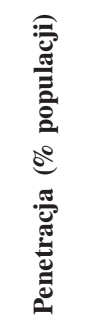 & 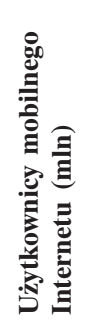 & 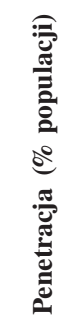 \\
\hline 38,42 & $60 \%$ & 27,92 & $72 \%$ & 52,2 & $136 \%$ & 23,73 & $62 \%$ \\
\hline
\end{tabular}

Źródło: GUS 2017.

Według danych GUS, w końcu września 2017 roku liczba abonentów i użytkowników telefonii komórkowej wynosiła w Polsce 52,2 mln. Na 100 mieszkańców przypadało 135,8 abonentów i użytkowników (GUS, 2017). Według badania przeprowadzonego przez Google w 2017 roku wśród polskiej populacji, $82 \%$ badanych używa Internetu codziennie (tabela 6), w 57\% uzyskuje dostęp poprzez urządzenia mobilne (tabela 7 ), w $80 \%$ po to by szukać potrzebnej informacji, a 55\% posiada więcej niż trzy urządzenia: komputer, smartfon, TV. 
Tabela 6. Częstość wejść do Internetu (Google 2017)

\begin{tabular}{|l|c|}
\hline \multicolumn{1}{|c|}{ Częstość dostępu do Internetu } & Udzial (\%) \\
\hline Codziennie $82 \%$ & 82 \\
\hline 1 x tydzień $13 \%$ & 13 \\
\hline 1 x miesiąc $4 \%$ & 4 \\
\hline$<1$ x miesiąc $1 \%$ & 1 \\
\hline
\end{tabular}

Źródło: Google (2017). Consumer barometer.

Tabela 7. Dostęp do Internetu za pomocą urządzeń

\begin{tabular}{|l|c|c|}
\hline Dostęp do Internetu za pomocą urządzeń & Udział (\%) & Zmiana 2015/2016 \\
\hline Latpop/desktop & 42 & $-12 \%$ \\
\hline Telefon komórkowy & 57 & $+12 \%$ \\
\hline Tablet & 2 & $-10 \%$ \\
\hline
\end{tabular}

Źródło: Digital in 2017 Global Overview, We Are Social.

Potwierdzają to wyniki opublikowane w raporcie Digital in 2017 Global Overview firmy We Are Social (tabela 8), wskazujące na silny trend ewolucji technologicznej w kierunku rozwiązań mobilnych. Ich konsekwencją jest głęboka wirtualizacja środowiska komunikacji międzyludzkiej, a w szczególności ich wpływ na relację lekarz-pacjent.

Tabela 8. Udział użytkowników urządzeń elektronicznych w dorosłej populacji

\begin{tabular}{|l|c|}
\hline \multicolumn{1}{|c|}{ Użytkownicy urządzeń } & \% dorosłej populacji \\
\hline Telefon komórkowy & 92 \\
\hline Smartfon & 61 \\
\hline Laptop / desktop & 78 \\
\hline Tablet & 25 \\
\hline TV & 85 \\
\hline E-czytnik/ e-book & 3 \\
\hline E-urządzenia do noszenia & 3 \\
\hline
\end{tabular}

Źródło: jak w tabeli 7. 


\section{Telemedycyna}

W Wielkiej Brytanii, brytyjski narodowy fundusz zdrowia (NHS) testuje rozwiązanie oparte na sztucznej inteligencji firmy Babylon, która poprzez serię naprowadzających pytań zadawanych pacjentowi, jest w stanie wygenerować wstępną diagnozę i następnie skontaktować wirtualnie z dostępnym lekarzem. Według wstępnych wyników, $85 \%$ konsultacji nie wymaga osobistej wizyty u lekarza. Ma to ogromne znaczenie dla pacjentów przewlekle chorych, starszych, którzy nie są już tak mobilni (Babylon NHS).

Innowacją jest tu wstępny dialog (chat), jaki pacjent odbywa z samym systemem, który poprzez nakierowujące pytania (wbudowane setki algorytmów możliwych rozwiązań oraz możliwych określeń, jakie pacjent stosuje do opisu dolegliwości - podstawa funkcjonowania Artificial Intelligence), pomaga w postawieniu wstępnej diagnozy i sugeruje następny krok, np. video-chat z lekarzem pierwszego kontaktu w ciągu najbliższej godziny lub kieruje od razu do najbliższego szpitala w przypadku stwierdzenia zagrażających życiu objawów.

Również na polskim rynku są oferowane tele-serwisy dostępne dla pacjentów przez 24 godziny na dobę przez 7 dni w tygodniu (24/7), z możliwością video-chatu z lekarzem, ta usługa jest dostępna od poniedziałku do piątku w godzinach 7.00-24.00, w ramach abonamentu w Centrum Medycznym Medicover. Wprawdzie na razie video-chat odnosi się głównie do takich stanów, jak: przeziębienia, gorączka, kaszel, bóle brzucha, wymioty, infekcja układu moczowego czy wysypka, ale obejmuje również możliwość omówienia wyników badań czy poradę dotyczącą przyjmowanych leków.

\section{Aplikacje mobilne dla lekarzy}

Mimo zwiększającej się objętości i szybkości przesyłu informacji, niektóre dziedziny pozostają nadal niezmienione. Tak jest np. z naszą pamięcią. Znana „krzywa zapominania Ebbinghausa” (Green i in.) jest może niedoskonałym, ale istotnym wyznacznikiem trudności w trwałym zapamiętywaniu dużych partii materiału. Te dwa czynniki, postęp w technologii komunikacji oraz ograniczenia w pamiętaniu dużych ilości informacji, legły u podstaw rozwiązań, jakimi są mobilne aplikacje medyczne przeznaczone dla personelu medycznego (zob. Obraz 1). 
Obraz 1. Aplikacja HTbox, w nadciśnieniu firmy 3Clicks Sp. z o.o.

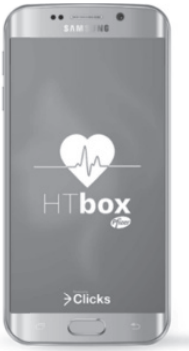

Strona startowa

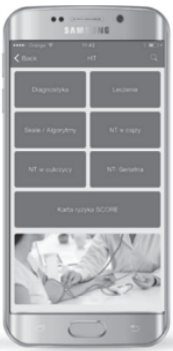

Strona główna

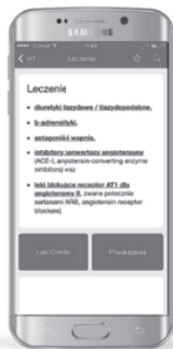

Grupy leków stosowane $\mathrm{W}$ leczeniu NT

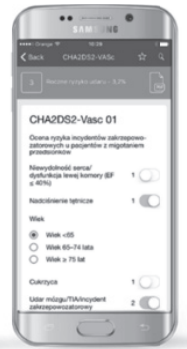

Skale diagnostyczne

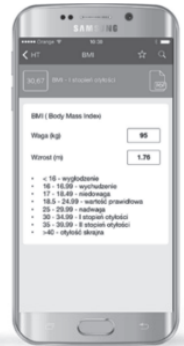

Kalkulator BMI

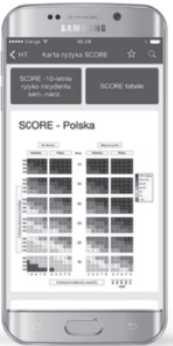

Karta oceny ryzyka sercowo-naczyniowege

Źródło: www.get3clicks.com

Spośród wielu czynników, które wpływają na efektywność i jakość procesów w szeroko rozumianej ochronie zdrowia, poniższe wydają się mieć zasadnicze znaczenie: dynamicznie rosnące koszty opieki zdrowotnej, rosnące oczekiwania świadczeniobiorców (pacjentów), starzejące się społeczeństwo, postęp technologiczny oraz rosnąca ekspozycja prawna dla świadczeniodawców. Współczesne aplikacje mobilne adresowane do lekarzy umożliwiają skuteczne zaadresowanie wszystkich powyższych czynników w zakresie, który pozwala na uzyskanie mierzalnych punktów końcowych.

Interaktywne, mobilne aplikacje medyczne dynamicznie zmieniają dzisiejsze otoczenie pracy lekarza. Dzięki zawartej w nich niezbędnej informacji, wspierającej proces diagnostyki i leczenia w prostym i intuicyjnym formacie, pozwalającym na szybki dostęp do poszukiwanej informacji, nie tylko podwyższają jakość procesu diagnostycznego i terapeutycznego, ale także skracają czas do postawienia właściwej diagnozy. W konsekwencji odpowiednie leczenie jest szybciej wprowadzane. Z tym wiążą się mniejsze koszty leczenia (szpitale, przychodnie, gabinety), krótszy czas absencji chorobowej pacjentów (mniejsze obciążenie systemu opieki zdrowotnej i ZUS). Ponadto, aplikacje dostępne przez 24 godziny przez 7 dni w tygodniu bez konieczności dostępu do Internetu zwiększają komfort pracy (jakość dokumentacji medycznej - mniejsza ekspozycja prawna) lekarza, niezależnie czy praktykuje on w dużym czy małym mieście i czy jest w swoim gabinecie z dostępem do komputera z Internetem, czy przy łóżku chorego.

Dzięki dostępowi do algorytmów diagnostyczno-terapeutycznych, skal diagnostycznych, czy wytycznych dotyczących leczenia, kryteriów kwalifikacji do programów lekowych, przeliczników dawek czy kalkulatorów, pozwalających na określenie wielkości opakowania, np. zawiesiny leku dla dzieci, lekarz uzy- 
skuje wsparcie przy rozpoznaniu oraz planowaniu odpowiedniej dalszej diagnostyki i leczenia. Skraca w ten sposób czas do uzyskania właściwej diagnozy, a w związku z tym przyspiesza niejako wdrożenie odpowiedniego leczenia - co skutkuje szybszym poprawieniem stanu zdrowia pacjenta, jego jakości życia, skróceniem absencji chorobowej, zmniejszeniem konieczności stosowania dodatkowego leczenia. Ponadto, skrócenie czasu poświęcanego na diagnostykę oraz optymalizację zakresu badań laboratoryjnych, obrazowych czy niezbędnych konsultacji specjalistycznych, koniecznych do ustalenia prawidłowej diagnozy, prowadzi w dłuższej perspektywie do obniżenia całkowitych kosztów leczenia. Biorąc pod uwagę zmiany demograficzne w społeczeństwie i fakt, że wielu pacjentów ze względu na wiek i wielochorobowość nie będzie w stanie dotrzeć do przychodni, możliwość wsparcia procesu diagnostycznego i terapeutycznego w domu chorego, przy jego łóżku, gdzie nie ma dostępu do Internetu, poprzez wykorzystanie odpowiedniej skali diagnostycznej, algorytmu postępowania, tudzież sprawdzenie potencjalnych interakcji lekowej, uzyskuje kluczowe znaczenie w sukcesie diagnostycznym i terapeutycznym.

Dodatkowo istnieje wymóg prawny, zgodnie z wykładnią Sądu Najwyższego, naruszenia prawa pacjenta do tej informacji należy doszukiwać się bez względu na to, czy wystąpiły skutki w postaci uszkodzenia lub rozstroju zdrowia (artykuł 9 Ustawy o Prawach Pacjenta i Rzeczniku Praw Pacjenta).

Nie tylko sam lekarz jest beneficjentem tych nowych rozwiązań. Pacjent, który cały czas pozostaje w centrum procesu terapeutycznego, dzięki pełnej informacji, może bardziej świadomie uczestniczyć w procesie leczenia.

Zastosowanie aplikacji mobilnych jako nowej kategorii wsparcia codziennych procesów decyzyjnych, pozwala na optymalizację przebiegu procesu diagnostyczno-terapeutycznego, niesie ze sobą zmniejszenie niepotrzebnych badań dodatkowych, konsultacji specjalistycznych i skraca czas do uzyskania właściwej diagnozy i w konsekwencji wdrożenia odpowiedniego leczenia. W uproszczeniu ze strony pacjenta w wyniku wdrożenia leczenia szybciej ustępują dolegliwości i poprawia się jakość życia. Pacjent szybciej wraca do rodziny i do społeczeństwa. Potencjalne oszczędności dla budżetu ochrony zdrowia są oczywiste, dla budżetu placówek służby zdrowia, w tym szpitali, optymalizacja diagnostyki i terapii niesie istotne oszczędności.

\section{Urządzenia wspomagające połączone ze smartfonem}

Rejestrator EKG HR-2000, Istel, polskiej firmy Diagnosis, przenośny aparat do EKG, analizuje sześć odprowadzeń kończynowych i dzięki technologii Bluetooth umożliwia analizę EKG na smartfonie (zob. Obraz 2). 
Obraz 2. Rejestrator EKG Istel HR 2000

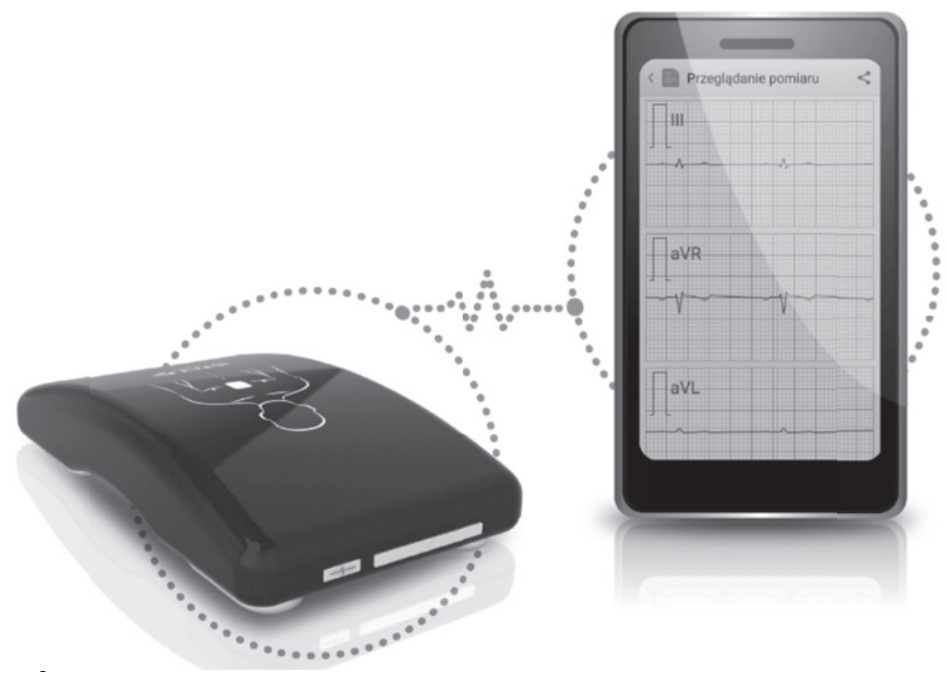

Źródło: EKG Istel HR 2000.

Zastosowanie nowych technologii dzięki miniaturyzacji oferuje możliwość szybkiego wykrycia zaburzeń rytmu serca i ich udokumentowania. Ma to nieocenione zalety, bowiem pacjent może nagrać badanie w chwili odczuwania dolegliwości i następnie przesłać je lekarzowi prowadzącemu do dalszej diagnostyki. Ma to ogromne znaczenie, zwłaszcza w dolegliwościach o charakterze napadowym, kiedy trudno jest wychwycić naturę zmian.

Amerykańska Agencja ds. Żywności i Leków (FDA) 13 listopada 2017 roku zaakceptowała system o nazwie „Abilify MyCite”. Składa się on z klasycznej tabletki zawierającej substancję leczniczą - arypiprazol (Abilify firmy Otsuka Pharmaceuticals), lek wskazany w leczeniu schizofrenii, epizodów maniakalnych w zaburzeniu afektywnym dwubiegunowym oraz wbudowany w tabletkę sensor (Proteus Digital Health), który poprzez przylepiony specjalny plaster, transmituje sygnał poprzez Bluetooth do telefonu komórkowego o tym czy lek został przez pacjenta przyjęty. Wbudowany w tabletkę sensor wielkości ziarnka piasku składa się z krzemu, miedzi i magnezu, które po zetknięciu z sokiem żołądkowym emitują sygnał elektryczny wykrywany przez przylepiony do skóry sensor. Jest to pierwszy na świecie tego typu system zaaprobowany przez FDA, co otwiera szeroko drzwi do podobnych rozwiązań.

Koszty braku przyjmowania leków zgodnie z zaleceniem lekarza (non-compliance) są w systemie opieki zdrowotnej bardzo wysokie. Lek, którego 
pacjent nie przyjmuje - nie działa. W USA rocznie jest to kwota pomiędzy 100-290 mld dolarów (Viswanathan i in., 2012, s. 785-795). Zastosowanie rozwiązań pozwalających poprawić adherencję pacjentów jest długo oczekiwanym krokiem naprzód.

\section{Przyszłość: Alexa Amazon}

Wyobraźmy sobie sytuację, w której pacjent odczuwa silny ból w klatce piersiowej i jego przeżycie zależy od szybkości uzyskania specjalistycznej pomocy. A tą pomoc uzyskuje on od systemu po komunikacie słownym „Alexa”. System komputerowy rozpoznający ludzką mowę firmy Amazon (na razie wersja $\mathrm{z}$ językiem polskim jest niedostępna), jest w stanie poprzez naprowadzające pytania, które zostały specjalnie przygotowane przez Amerykańskie Towarzystwo Kardiologiczne, określić główne dolegliwości i ustalić wstępną ścieżkę dalszego postępowania. Na co dzień „Alexa” odpowie na każde zadane pytanie, zaproponuje rozwiązania, powiadomi odpowiednie służby medyczne i administracyjne, jeśli to konieczne (zob. Obraz 3). Może on towarzyszyć jako aktywny komunikator starszym ludziom, podnosząc ich jakość samotnego życia, przypominając choćby o terminach wizyt lekarskich czy konieczności przyjęcia leku.

Obraz 3. System Alexa (Amazon)

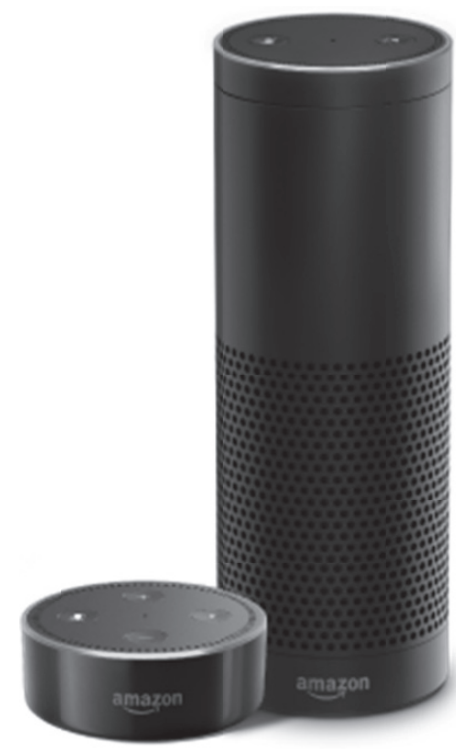

Źródło: https://amazon.com. 


\section{Dyskusja}

Analiza bieżących trendów demograficznych potwierdziła cechy starzenia się populacji naszego kraju. Z opublikowanych raportów statystycznych GUS, OECD i Eurostatu widoczny jest wzrost zachorowalności wraz z wiekiem. W kardiologii wiek (powyżej 65 roku życia) i płeć są traktowane jako osobne czynniki ryzyka chorób układu krążenia (ChUK). Od istniejących trendów demograficznych nie są wolni świadczeniodawcy, czyli lekarze. Tu wpływ starzenia się społeczeństwa jest bardziej widoczny ze względu na dodatkowy czynnik emigracji młodego pokolenia lekarzy.

Podsumowując, czynniki demograficzne, ponieważ nie są modyfikowalne, w sposób istotny wpływają obciążająco na system opieki zdrowotnej. Populacja pacjentów z chorobami układu krążenia nie jest tu wybrana przypadkowo. Według danych statystycznych schorzenia układu krążenia są od lat najczęstszą przyczyną umieralności w Unii Europejskiej i w Polsce. Wskaźniki chorobowości populacji, a konkretnie wynikające z nich wskaźniki absencji chorobowej w pracy, mają znaczący wpływ na kondycję przedsiębiorstw i gospodarki całego kraju. Jak wynika z danych ZUS i GUS, dominującymi przyczynami absencji chorobowej w Polsce są schorzenia układu kostno-stawowego i mięśniowego. Natomiast nie odpowiadają one za większą umieralność populacji. Przyczyną niedoszacowania wpływu schorzeń kardiologicznych, takich jak: źle leczone nadciśnienie tętnicze, otyłość, podwyższone poziomy cholesterolu LDL i glukozy, czy zwykły brak ruchu i dieta tłuszczowa, nie wspominając o nikotynizmie i zwiększonej konsumpcji alkoholu, jest fakt, że na te dolegliwości nie są wydawane zwolnienia lekarskie. Stąd nie są one widoczne w systemie. Dopiero skutki złego stylu życia są widoczne w postaci choroby niedokrwiennej serca czy udarów mózgu.

Wiele z wyżej wymienionych czynników ryzyka chorób sercowo-naczyniowych jest modyfikowalnych, stąd ogromne oczekiwania wiążą się z wykorzystaniem innowacyjnych rozwiązań z dziedziny nowych technologii w komunikacji cyfrowej, aplikacji mobilnych czy przetwarzania informacji w celu zwiększenia adherencji pacjentów do leczenia, a także wsparcia procesów diagnostycznoterapeutycznych świadczeniodawców.

Przy rosnących kosztach systemów ochrony zdrowia, wynikających ze starzenia się populacji, i w związku z tym większej chorobowości, rozwiązaniem może być szersza i szybsza adopcja nowych technologii zarówno dla świadczeniodawców, jak i świadczeniobiorców. Analiza roli innowacyjnych rozwiązań technologicznych w nowym otoczeniu rynkowym została przedstawiona w tym opracowaniu. 


\section{Ograniczenia systemowe}

Adopcja innowacyjnych systemów informatycznych, oraz nowych mobilnych technologii cyfrowych przyniesie maksymalny efekt w chwili, kiedy systemy te są zintegrowane, a informacje w nich gromadzone dostępne dla wszystkich interesariuszy w odpowiednim formacie. Rzeczywistość jest jednak daleka od ideału. Wynika to z braku spójnej polityki zarządzania obiegiem informacji medycznej. Systemy informatyczne obsługujące np. przychodnie lekarskie, czy szpitale są wybierane na drodze zamówień publicznych, a decydującym kryterium jest cena. $\mathrm{W}$ rezultacie na rynku mamy wiele różnych systemów, które nie są wzajemnie kompatybilne i uniemożliwiają swobodny przepływ informacji medycznej.

\section{Bibliografia}

Babylon NHS, https://www.babylonhealth.com/uploads/home/babylon-NHS-brochure.pdf

Centralny Rejestr Lekarzy RP, NIL. Liczba aktywnych zawodowo lekarzy według wieku i płci na dzień 30.09.2017 r., http://www.nil.org.pl/rejestry/centralny-rejestr-lekarzy/informacje-statystyczne.

Chapman, L. (2006). Proof Positive: An Analysis of the Cost- Effectiveness of Wellness. Summex Health Management (Sixth Edition).

Chomik, S., Hoffman, P. (2016). Niewydolność serca u kobiet w podeszłym wieku. Jak leczyć?, Przeglad Lekarski, 73(6).

Denissov, G. (2016). Sharp Decrease in Observed Cerebrovascular Mortality May Be Due to Certification and Coding. Scandinavian Journal of Public Health, 44.

Digital in 2017 Global Overview, We Are Social, https://wearesocial.com/uk/special-reports/ digital-in-2017-global-overview (dostęp: 27.11.2017).

DzU (1997). Ustawa z dnia 29.08.1997 roku o ochronie danych osobowych, nr 133 poz. 883, http://prawo.sejm.gov.pl/isap.nsf/DocDetails.xsp?id=WDU19971330883 (dostęp: 27.11.2017).

DzU (2009). Ustawa z dnia 6 listopada 2008 roku o prawach pacjenta i Rzeczniku Praw Pacjenta, nr 52 poz. 417, http://prawo.sejm.gov.pl/isap.nsf/DocDetails.xsp?id=WDU20090520417 (dostęp: 27.11.2017).

EKG Istel HR 2000, http://diagnosis.pl/produkty/rejestrator-ekg-istel-hr-2000

Eurostat (2016). Causes of Death Statistics - People Over 65. Eurostat Statistics Explained. European Commission, Luxembourg, May.

Goetzel, R., Long, S., Ozminkowski, R., Hawkins, K., Wang, S., Lynch, W. (2004). Health, Absence, Disability and Presenteeism Cost Estimates of Certain Physical and Mental Health Conditions Affecting U.S. Employers. Journal of Occupational and Environmental Medicine, 46(4).

Google (2017). Consumer barometer, https://www.consumerbarometer.com/en/graph-builde r/?question $=$ M6\&filter $=$ country:poland $($ dostęp: 27.11.2017).

Green, Ch.D. i in. Classics in the History of Psychology - Ebbinghaus (1885/1913). Chapter 1, psychclassics.yorku.ca (dostęp: 24.11.2017). 
GUS (2014). Prognoza ludności na lata 2014-2050. Studia i Analizy Statystyczne. Warszawa. GUS (2017), http://stat.gov.pl/obszary-tematyczne/inne-opracowania/informacje-o-sytuacjispoleczno-gospodarczej/informacja-o-sytuacji-spoleczno-gospodarczej-kraju-i-iii-kwartal2017-r-,1,65.html (dostęp: 27.11.2017).

GUS Raport (2017). Ludność. Stan i struktura w przekroju terytorialnym. Stan w dniu 30.06.2017, http://stat.gov.pl/obszary-tematyczne/zdrowie/ (dostęp: 27.11.2017).

Harvey, J., Nicholson, N. (1993). Incentives and penalties as means of influencing attendance: a study in the UK public sector. International Journal of Human Resource Management, 4(4).

Łyszczarz, B., Gierczyński, J., Nojszewska, E., Śliwczyński, A., Zalewska, H., Karczewicz, E., Sznyk, A. (2017). Ocena kosztów niewydolności serca $w$ Polsce z perspektywy gospodarki państwa. Warszawa: Instytut Innowacyjna Gospodarka.

OECD (2015). Cardiovascular Disease and Diabetes: Policies for Better Health and Quality of Care. Paris: OECD Publishing, http://dx.doi.org/10.1787/9789264233010-en (dostęp: 26.11.2017).

OECD Raport (2016). Health at a Glance: Europe 2016. Eurostat Database.

PTK. Europejskie wytyczne dotyczace prewencji chorób sercowo-naczyniowych w praktyce klinicznej, http://www.ptkardio.pl

Raport EY (2013). Metodyka pomiaru kosztów pośrednich w polskim systemie ochrony zdrowia. Warszawa.

RODO (2016). Rozporządzenie Parlamentu Europejskiego i Rady (UE) 2016/679 z dnia 27 kwietnia 2016 r. w sprawie ochrony osób fizycznych w związku z przetwarzaniem danych osobowych i w sprawie swobodnego przepływu takich danych oraz uchylenia dyrektywy 95/46/WE, http://eur-lex.europa.eu/legal-content/PL/TXT/HTML/?uri=CELEX:32016R0679\&from=en (dostęp: 26.11.2017).

Rządowa Rada Ludnościowa, http://bip.stat.gov.pl/organizacja-statystyki-publicznej/rzadowarada-ludnosciowa/publikacje-rzadowej-rady-ludnosciowej (dostęp: 27.11.2017).

Smartbandy, http://www.benchmark.pl/testy_i_recenzje/jaka-opaske-fitness-wybrac.html

United Nations (2017). World Population Prospects: The 2017 Revision, www. https://esa. un.org/unpd/wpp/ (dostęp: 26.11.2017).

Viswanathan, M. i in. (2012). Interventions to improve adherence to self-administered medications for chronic diseases in the United States. Annals of Internal Medicine, 157(11).

ZUS (2016). Raport na temat absencji chorobowej, http://www.zus.pl/baza-wiedzy/statystyka/ opracowania-tematyczne/absencja-chorobowa (dostęp: 26.11.2017). 

DOI: 10.7172/978-83-66282-07-0.2019.wwz.2.4

\title{
Zofia Skrzypczak ${ }^{1}$
}

\section{Położne w Polsce}

\section{Streszczenie}

Mając świadomość ogromnego znaczenia zasobów ludzkich dla funkcjonowania systemu opieki zdrowotnej, w niniejszym rozdziale zaprezentowano zasoby jednej z profesji medycznych - położnych w Polsce (na tle innych krajów europejskich).

Tę grupę profesjonalistów medycznych - podobnie jak lekarzy i pielęgniarek - cechuje istotna różnica między liczbą osób posiadających prawo wykonywania zawodu a liczbą zatrudnionych w placówkach medycznych. Zatrudnieni w zawodzie położnej stanowią tylko około 60\% osób mających prawo wykonywania zawodu (z tendencją spadkową w ostatnich latach).

W rozdziale tym podjęto próbę określenia czynników determinujących tę sytuację. Zwrócono także uwagę na niepokojące zjawisko "starzenia się" polskich położnych (średnia wieku wzrosła z 43,2 lat w 2008 roku do 48,7 lat w 2016 roku) i tzw. braku zastępowalności pokoleniowej (w ostatnich pięciu latach znacząco wzrósł udział w populacji położnych osób z przedziałów wiekowych: 56-60 lat, 61-65 lat i ponad 65 lat, natomiast spadł udział położnych z przedziałów wiekowych: 36-40 lat, 41-45 lat).

Słowa kluczowe: zasoby ludzkie w ochronie zdrowia, prawo wykonywania zawodu medycznego, „starzenie się" personelu medycznego.

\section{Midwives in Poland}

\begin{abstract}
Given the huge importance of human resources for the functioning of the healthcare system, this chapter presents the resources of one of medical professions - midwives in Poland (compared to other European countries).

This group of medical professionals, similarly to doctors and nurses, is characterised by a significant difference between the number of people with the right to practice and the number of employees

1 Zofia Skrzypczak - dr, Centrum Zarządzania w Ochronie Zdrowia, Katedra Gospodarki Narodowej, Wydział Zarządzania Uniwersytetu Warszawskiego, ul. Szturmowa 1/3, 02-678 Warszawa, e-mail: skrzypczak@wz.uw.edu.pl; ORCID: 0000-0002-0062-920X.
\end{abstract}


in medical facilities. Employed midwives represent only about $60 \%$ of people with the right to practice (with a downward trend in recent years).

This chapter attempts to identify the factors determining this situation. Attention is also paid to the worrying phenomenon of "ageing" of Polish midwives (the average age increased from 43.2 years in 2008 to 48.7 years in 2016) and the so-called lack of generational substitutability (the last five years have witnessed a considerable rise in the share of midwives in age groups: 56-60, 61-65 and over 65 years, while the share of midwives in age groups: 36-40, 41-45 years has dropped).

Keywords: human resources in healthcare, right to practice a medical profession, "ageing" of medical staff.

\section{Wprowadzenie}

Jednym z zasadniczych elementów systemu opieki zdrowotnej w każdym kraju są zasoby ludzkie. Ich stan determinuje dostępność opieki medycznej, jakość świadczonych usług medycznych, rzutuje na zadowolenie pacjentów i ich opinie o funkcjonowaniu systemu opieki zdrowotnej. W raporcie Światowej Organizacji Zdrowia (WHO) znalazło się wręcz stwierdzenie, iż usługi medyczne o wysokiej jakości można zapewnić poprzez połączenie zasobów: ludzkich, finansowych i materialno-technicznych. Zasoby ludzkie są rozumiane jako zasób kwalifikacji i umiejętności wszystkich tych, którzy funkcjonują w systemie opieki zdrowotnej. Są one uwarunkowane w głównej mierze wiedzą, umiejętnościami i motywacją pracowników (Zybała, 2009).

Zawody medyczne są tzw. zawodami regulowanymi - w większości krajów europejskich operuje się w odniesieniu do tych profesji zarówno liczbą osób uprawnionych do wykonywania zawodów, jak i liczbą osób faktycznie pracujących w placówkach ochrony zdrowia. Dominującą grupą wśród profesjonalistów medycznych są zdecydowanie pielęgniarki - w sektorze publicznym i niepublicznym w Polsce było zatrudnionych w 2015 roku około 185 tys. pielęgniarek, co stanowiło około $65 \%$ uprawnionych do wykonywania tego zawodu. Liczba zatrudnionych lekarzy wyniosła w 2015 roku 86,5 tys. osób - co stanowiło około $60 \%$ uprawnionych do wykonywania zawodu; zatrudnionych położnych było około 22 tys., czyli ponad $60 \%$ osób, mających prawo wykonywania zawodu.

Szczególną grupę pracowników służby zdrowia stanowią położne, które zajmują się zarówno edukacją i poradnictwem w zakresie planowania rodziny, jak i działaniami w zakresie promocji zdrowia i profilaktyki chorób położniczoginekologicznych. Jednak głównym zadaniem położnych jest opieka w okresie ciąży, porodu i połogu, opieka nad kobietą, noworodkiem i niemowlęciem do ukończenia drugiego miesiąca życia, opieka w nad kobietą z chorobami ginekologicznymi. 
Dla prawidłowej realizacji swoich zadań i świadczeń w zakresie opieki zdrowotnej położna współpracuje $\mathrm{z}$ lekarzem ginekologiem, a w przypadku położnej podstawowej opieki zdrowotnej (POZ) - również z lekarzem POZ, pielęgniarką POZ oraz przedstawicielami organizacji i instytucji działających na rzecz zdrowia. Liczba położnych, organizacja i jakość ich pracy ma bezpośrednie przełożenie na stan zdrowia kobiet w każdym okresie życia, przygotowanie i prowadzenie ciąży oraz opiekę poporodową. Nie bez znaczenia jest również rola położnych w kształtowaniu prawidłowych postaw rodzicielskich, promowaniu karmienia piersią, poradnictwie z zakresie higieny, pielęgnacji i prawidłowego odżywiania w okresie ciąży i połogu.

Celem niniejszego opracowania jest analiza zmian liczby położnych w Polsce w latach 2008-2016, prezentacja ich aktualnej sytuacji oraz porównanie $\mathrm{z}$ wybranymi krajami europejskimi.

\section{Położne mające prawo wykonywania zawodu}

Zawód położnej to - podobnie jak lekarza i pielęgniarki - zawód medyczny regulowany. Może go wykonywać osoba posiadająca prawo wykonywania zawodu położnej, stwierdzone przez okręgową radę pielęgniarek i położnych. Prawo wykonywania zawodu położnej uzyskuje osoba, która:

- posiada świadectwo lub dyplom ukończenia polskiej szkoły położnych, bądź uzyskane w innym państwie niż państwo członkowskie Unii Europejskiej świadectwo lub dyplom, pod warunkiem, że dyplom lub świadectwo zostały uznane w Rzeczypospolitej Polskiej za równorzędne ze świadectwem ukończenia szkoły pielęgniarskiej lub dyplomem, zgodnie z odrębnymi przepisami oraz, że spełnia minimalne wymogi kształcenia określone w przepisach prawa Unii Europejskiej;

- posiada pełną zdolność do czynności prawnych;

- której stan zdrowia pozwala na wykonywanie zawodu położnej;

- wykazuje nienaganną postawę etyczną (Zabezpieczenie, 2015a).

Położne muszą być zdolne pomagać, nadzorować i pielęgnować kobiety w czasie ciąży, porodu i połogu, na własną odpowiedzialność odbierać porody oraz pielęgnować noworodki i niemowlęta. Opieka ta polega na działaniach profilaktycznych, wykrywaniu stanów nieprawidłowych u matki i dziecka, dostarczaniu pomocy medycznej i realizowaniu działań pomocy doraźnej. Istotnym zadaniem położnych jest poradnictwo zdrowotne oraz edukacja, nie tylko kobiet, lecz także rodziny i społeczności. Praca położnej powinna obejmować edukację przedporodową i przygotowanie do rodzicielstwa, a także uwzględ- 
niać niektóre obszary ginekologii, planowania rodziny i opieki nad dziećmi (Iwanowicz-Palus i in., 2013, s. 117-122).

W tabeli 1 przedstawiono liczbę położnych mających prawo wykonywania zawodu w Polsce w latach 2008-2016 (według stanu Centralnego Rejestru Pielęgniarek i Położnych na 31 grudnia każdego roku).

Tabela 1. Liczba położnych zarejestrowanych w Centralnym Rejestrze Pielęgniarek i Położnych w latach 2008-2016

\begin{tabular}{|c|c|c|c|c|}
\hline Stan na 31 grudnia & Kobiety & Mężczyźni & Razem & Średnia wieku \\
\hline 2008 & 32429 & 45 & 32474 & 43,23 \\
\hline 2009 & 32990 & 36 & 33026 & 43,96 \\
\hline 2010 & 33477 & 50 & 33527 & 44,66 \\
\hline 2011 & 33733 & 57 & 33790 & 45,32 \\
\hline 2012 & 34327 & 60 & 34387 & 46,09 \\
\hline 2013 & 34750 & 64 & 34814 & 47,69 \\
\hline 2014 & 35389 & 65 & 35454 & 47,21 \\
\hline 2015 & 36026 & 69 & 36095 & 48,72 \\
\hline 2016 & 36737 & 69 & 36806 & 48,72 \\
\hline
\end{tabular}

Źródło: Zabezpieczenie społeczeństwa polskiego w świadczenia pielegniarek i położnych. Raport Naczelnej Rady Pielęgniarek i Położnych (2017). Naczelna Izba Pielęgniarek i Położnych. Warszawa marzec, tabela 9 , s. 28 .

Wykres 1. Liczba położnych posiadających prawo wykonywania zawodu i ich średnia wieku w latach 2008-2016

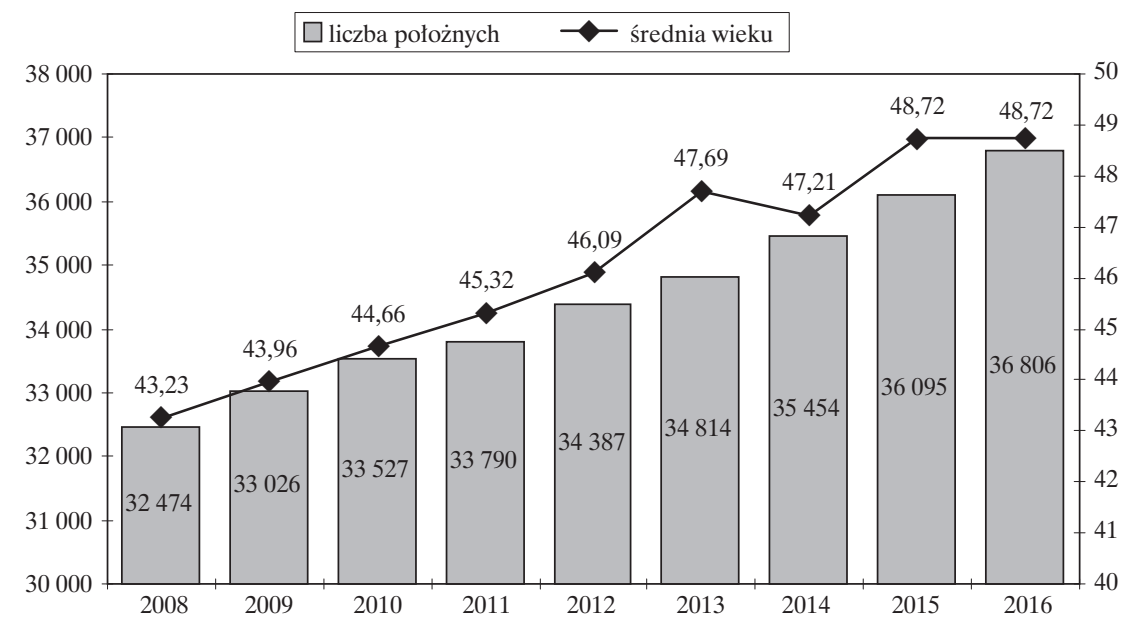

Źródło: jak w tabeli 1. 
W minionych latach liczba położnych mających prawo wykonywania zawodu systematycznie - chociaż w niewielkim tempie - wzrastała. Wzrastała również - niestety - średnia wieku położnych: z poziomu około 43 lat w 2008 roku do prawie 49 lat w 2016 roku.

Na wykresie 2 przedstawiono - dla lat 2012-2016 - strukturę według wieku położnych, mających prawo wykonywania zawodu w Polsce.

Wykres 2. Struktura według wieku położnych mających prawo wykonywania zawodu w Polsce w latach 2012-2016

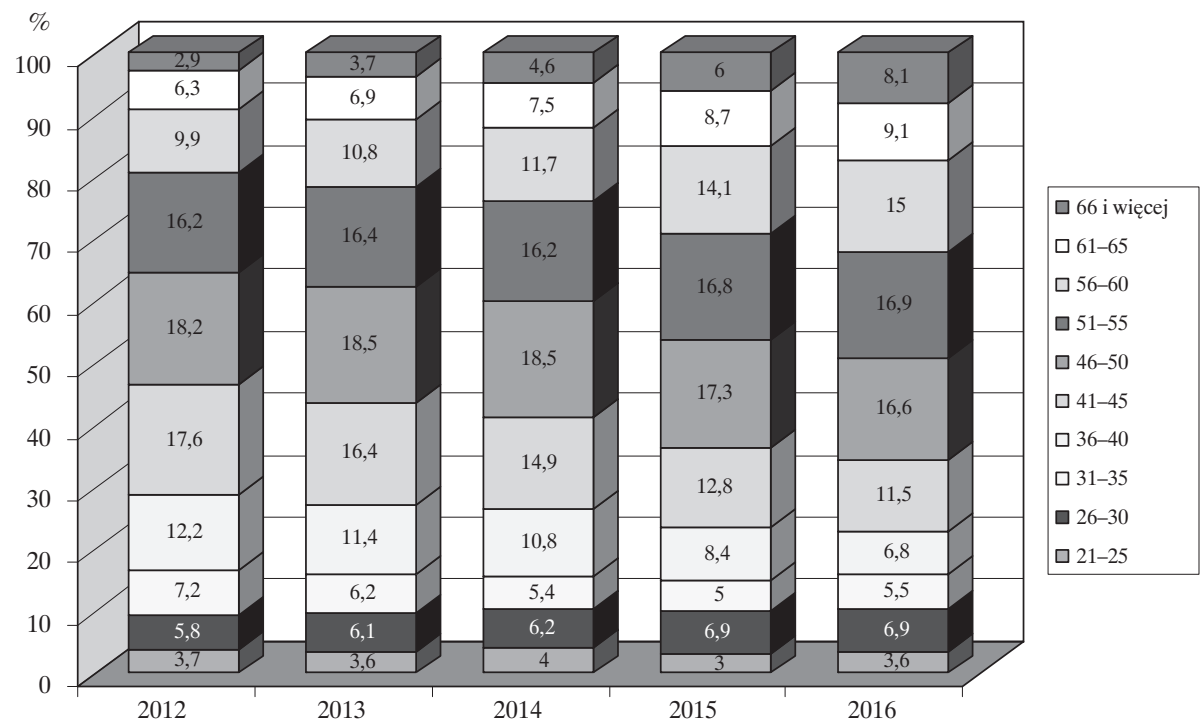

Źródło: zestawienie własne na podstawie danych Centralnego Rejestru Pielęgniarek i Położnych.

Analiza wykresu 2 pozwala stwierdzić, że w ostatnich pięciu latach znacząco wzrósł udział w populacji położnych osób z przedziałów wiekowych: 56-60 lat (wzrost z około 10\% do 15\%), 61-65 lat (wzrost z 6,3\% do 9,1\%) i ponad 65 lat (wzrost z niespełna 3\% do 8\%). Zjawisku temu towarzyszył spadek udziału w populacji położnych osób z przedziałów wiekowych: 36-40 lat (z 12,2\% w 2012 roku do 6,8\% w 2016 roku), 41-45 lat (z 17,6\% do 11,5\%) oraz względna stabilizacja udziału najmłodszych położnych z grupy wiekowej 21-25 lat (około 3,5\%) i niewielki wzrost udziału położnych w wieku 26-30 lat (z około $6 \%$ do około $7 \%$ ).

Opisane zjawiska świadczą o niewystępowaniu tzw. prostej zastępowalności pokoleniowej w obrębie położnych posiadających prawo wykonywania zawodu w Polsce. 


\section{Zatrudnienie położnych w sektorze ochrony zdrowia $\mathrm{i}$ jego determinanty}

Położne mające prawo wykonywania zawodu mogą wykonywać swój zawód, udzielając świadczeń zdrowotnych w podmiocie leczniczym lub w ramach praktyki zawodowej, ale ich praca może być również związana z procesem edukacji (kształcenia zawodowego) oraz administrowania w ochronie zdrowia.

W tabeli 2 przedstawiono liczbę położnych zatrudnionych w placówkach sektora ochrony zdrowia w Polsce w latach 2010-2016.

Tabela 2. Liczba położnych zatrudnionych w placówkach sektora ochrony zdrowia w Polsce w latach 2010-2015 oraz ich udział w mających prawo wykonywania zawodu położnej

\begin{tabular}{|c|c|c|}
\hline Lata & $\begin{array}{c}\text { Położne zatrudnione } \\
\text { w placówkach ochrony zdrowia }\end{array}$ & $\begin{array}{c}\text { Położne zatrudnione w ochronie zdrowia } \\
\text { jako \% mających prawo wykonywania } \\
\text { zawodu }\end{array}$ \\
\hline 2010 & 22193 & 64,7 \\
\hline 2011 & 22730 & 65,7 \\
\hline 2012 & 24069 & 68,5 \\
\hline 2013 & 22473 & 64,5 \\
\hline 2014 & 21949 & 61,9 \\
\hline 2015 & 22051 & 61,1 \\
\hline
\end{tabular}

Źródło: zestawienie własne na podstawie: Biuletynów Statystycznych Ministerstwa Zdrowia z lat 2011-2016. Warszawa: Centrum Systemów Informacyjnych Ochrony Zdrowia, www.csioz.gov.pl

Liczba położnych zatrudnionych w placówkach systemu ochrony zdrowia w Polsce w latach 2010-2015 przekraczała nieco poziom 22000 osób (z wyjątkiem 2014 roku, w którym statystyka podaje poziom zatrudnienia przekraczający nieco 24000 osób). Zatrudnione położne stanowiły w analizowanym okresie ponad $60 \%$ położnych posiadających prawo wykonywania zawodu; w latach 2012-2015 wystapiła tendencja spadkowa: z 68\% do 61\% (wykres 3).

Fakt, iż liczba zatrudnionych w systemie ochrony zdrowia położnych jest o około $40 \%$ niższa od liczby posiadających prawo wykonywania zawodu wynika z tego, że w grupie osób zarejestrowanych, tzn. mających prawo wykonywania zawodu położnej - oprócz pracujących w placówkach ochrony zdrowia - są także osoby:

- pracujące w innych zawodach,

- pracujące za granicą,

- przebywające na urlopach macierzyńskich i wychowawczych,

- bezrobotne,

- przebywające na emeryturze lub rencie. 
Wykres 3. Liczba położnych mających prawo wykonywania zawodu oraz zatrudnionych w placówkach sektora ochrony zdrowia jako \% mających prawo wykonywania zawodu w Polsce w latach 2010-2015

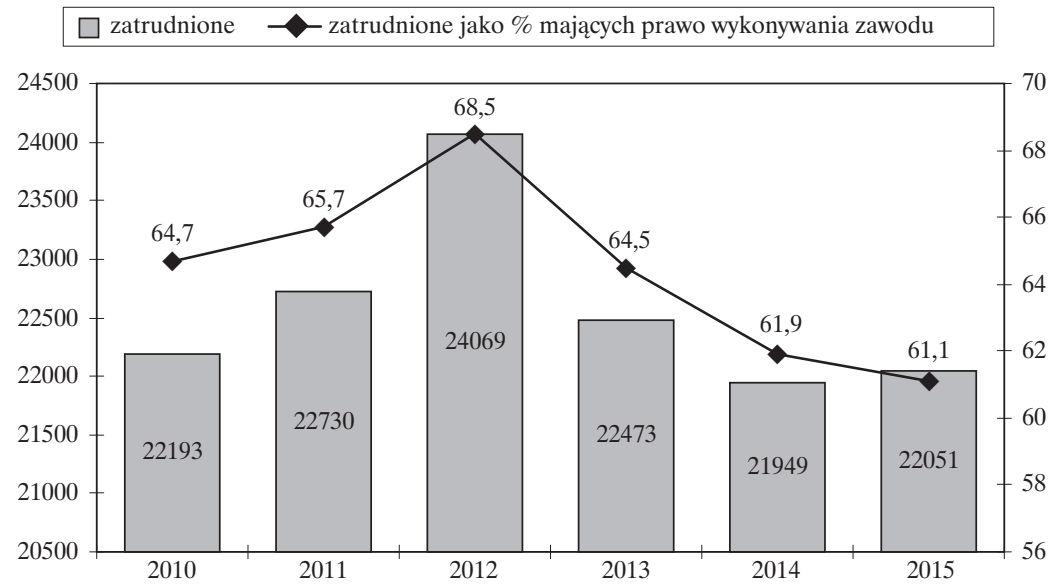

Źródło: jak w tabeli 2.

Do podjęcia pracy poza systemem opieki zdrowotnej i do wyjazdu do pracy za granicą motywują położne, posiadające prawo wykonywania zawodu, przede wszystkim niskie wynagrodzenia oferowane w sektorze ochrony zdrowia.

Tabela 3. Poziom przeciętnego miesięcznego wynagrodzenia brutto w gospodarce narodowej, w podmiotach gospodarczych zatrudniających powyżej 9 osób ogółem (ogółem oraz profesje medyczne) w latach 2010-2014 (w zł)

\begin{tabular}{|l|c|c|c|}
\hline & $\mathbf{2 0 1 0}$ & $\mathbf{2 0 1 2}$ & $\mathbf{2 0 1 4}$ \\
\hline Gospodarka narodowa* & 3225 & 3522 & 3783 \\
\hline $\begin{array}{l}\text { Podmioty gospodarcze zatrudniające powyżej 9 osób** } \\
\text { ogółem }\end{array}$ & 3544 & 3896 & 4108 \\
\hline Lekarze & 6663 & 6789 & 7041 \\
\hline Pielęgniarki & 3186 & 3277 & 3400 \\
\hline Położne & $\mathbf{3 3 0 1}$ & $\mathbf{3 2 3 2}$ & $\mathbf{3 3 7 2}$ \\
\hline Ratownicy medyczni & 3155 & 2961 & 3855 \\
\hline Diagności laboratoryjni & 3828 & 4157 & 4359 \\
\hline
\end{tabular}

Źródło: zestawienie własne na podstawie: * Rocznik Statystyczny RP 2013 (2014). Warszawa: GUS; Rocznik Statystyczny RP 2015 (2016). Warszawa: GUS; ** Struktura wynagrodzeń wedtug zawodów w październiku 2010 (2012). Warszawa: GUS; Struktura wynagrodzeń wedtug zawodów w październiku 2012 (2014). Warszawa: GUS: Struktura wynagrodzeń wedtug zawodów w październiku 2014 (2016). Warszawa: GUS. 
W tabeli 3 zestawiono przeciętne miesięczne wynagrodzenie brutto w gospodarce narodowej i płace przedstawicieli profesji medycznych zatrudnionych w sektorze ochrony zdrowia w latach 2010-2014.

Wykres 4. Poziom przeciętnego miesięcznego wynagrodzenia brutto w gospodarce narodowej, w podmiotach gospodarczych zatrudniających powyżej 9 osób (ogółem oraz profesje medyczne) w latach 2010-2014 (w zł)

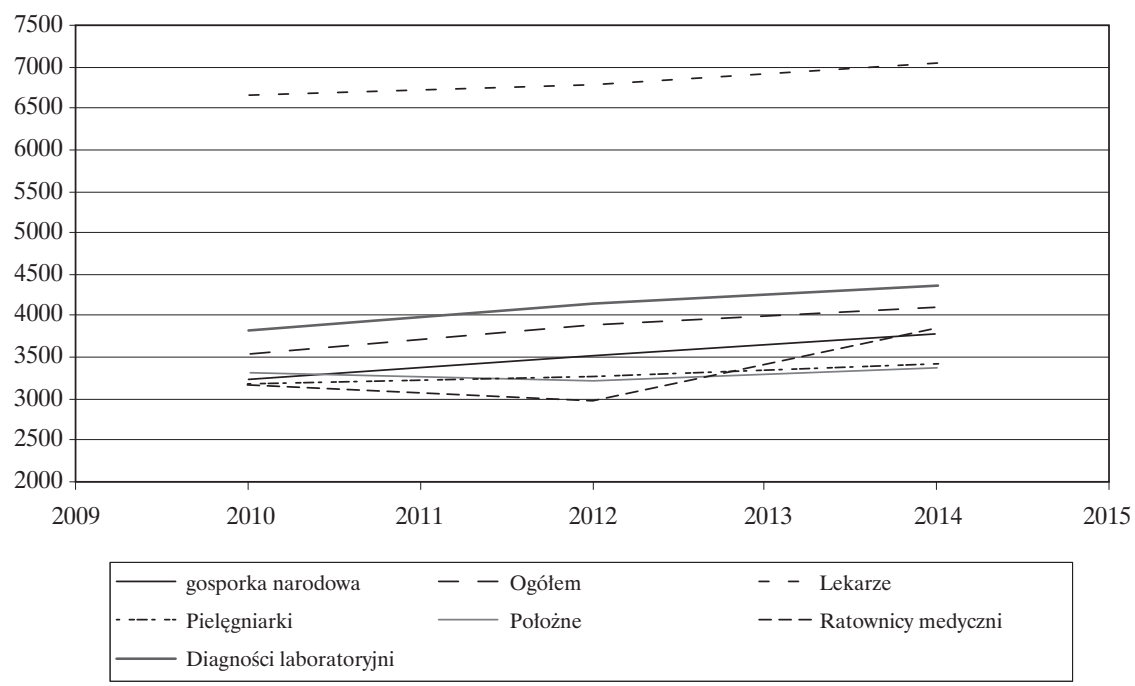

Źródło: jak w tabeli 3.

Analiza informacji zawartych w tabeli 3 i na wykresie 4 pozwala stwierdzić, że średnia płaca brutto położnych w latach 2010-2014 wzrosła minimalnie: z 3301 zł do 3372 zł, czyli o nieco ponad $2 \%$.

Jeżeli równocześnie zostanie uwzględniony fakt, iż w okresie 2010-2014 ceny dóbr i usług konsumpcyjnych wzrosły o 9,2\%, to wzrost średnich wynagrodzeń położnych o 2,15\%\% oznacza praktycznie spadek poziomu ich płacy realnej o 6,5\%, czyli znacznie mniejszą siłę nabywczą otrzymywanych wynagrodzeń i pogorszenie warunków życia przedstawicieli tej profesji medycznej.

Szczególnie trudnym okresem dla sytuacji bytowej położnych były lata 2010-2012. W tym czasie ich wynagrodzenie brutto zmniejszyło się o 2,1\%, a ceny dóbr konsumpcyjnych wzrosły o $8,2 \%$, nastąpił zatem spadek płacy realnej aż o 9,5\%. Natomiast w latach 2012-2014 sytuacja materialna położnych była nieco korzystniejsza, odnotowano wzrost ich średnich wynagrodzeń o 4,3\%, a ceny dóbr konsumpcyjnych wzrosły tylko o $0,9 \%$, czyli nastąpił wzrost płacy realnej o 3,4\% (Roczne wskaźniki makroekonomiczne, 2016). 
Równocześnie należy zauważyć, iż o ile w 2010 roku niższym od położnych przeciętnym wynagrodzeniem brutto charakteryzowały się pielęgniarki oraz ratownicy medyczni i niższa była również przeciętna płaca brutto w skali całej gospodarki narodowej, to już w 2014 roku przeciętne wynagrodzenie brutto położnych było najniższe.

Migracje z Polski lekarzy, pielęgniarek i położnych nasiliły się po wejściu Polski do Unii Europejskiej 1 maja 2004 roku. W ramach UE dostęp do wykonywania zawodu położnej podlega harmonizacji w zakresie niezbędnym do swobodnego przepływu osób i usług w ramach wspólnego rynku na podstawie zapisów Traktatu Ustanawiającego Wspólnotę Europejską. Dla profesjonalistów medycznych system ten oznacza pełną swobodę przemieszczania się pomiędzy krajami członkowskimi, swobodę wykonywania zawodu lub podejmowania działalności. W konsekwencji osoby poszukujące pracy - również w zawodzie położnej - mogą wykonywać ją w kraju, w którym mają największe możliwości rozwoju zawodowego i najkorzystniejsze warunki finansowe (Iwanowicz-Palus i in., 2013, s. 117-122).

Zjawisko migracji, naturalne w dobie globalizacji, chociaż umożliwia samodzielne decydowanie o miejscu pracy, to jednocześnie stwarza istotne problemy w systemach zdrowotnych tzw. krajów pochodzenia. Zgodnie ze strategia WHO, aby uporać się z problemami migracji międzynarodowej konieczne jest podjęcie działań we wszystkich krajach członkowskich i na arenie międzynarodowej. Wśród strategii w krajach źródłowych wymienia się m.in.: dostosowanie szkoleń zawodowych do potrzeb rynku, polepszenie warunków zatrudnienia pracowników oraz ułatwienie pracownikom powrotu do kraju po okresie pracy za granicą. Strategie w krajach docelowych powinny koncentrować się na zastosowaniu odpowiedniej polityki rekrutacyjnej, zapewnieniu wsparcia pracownikom w krajach źródłowych oraz uczciwym traktowaniu pracowników z emigracji. Strategie na arenie międzynarodowej powinny respektować równe prawa pracowników migrujących, przy jednoczesnej konieczności zapewnienia właściwej liczebności pracowników medycznych w krajach źródłowych (Włodarczyk, Domagała, 2011, s. 29-41).

Zawód pielęgniarki i położnej w krajach Europy Zachodniej, z uwagi na inną organizację systemu i powierzenie tej grupie zawodowej poważniejszych zadań, które w Polsce wciąż tradycyjnie przypisane są lekarzom, jest lepiej płatny, a także cieszy się większym prestiżem (Karkowski, 2015, s. 82-94).

Naczelna Izba Pielęgniarek i Położnych oraz okręgowe izby pielęgniarek i położnych prowadzą ośrodki informacyjno-edukacyjne w celu realizacji zadania wynikającego z ustawy z dnia 1 lipca 2011 roku o samorządzie pielęgniarek i położnych (DzU z 2011 r., nr 174 poz. 1038 ze zm.), polegającego na udziela- 
niu informacji na temat uznawania kwalifikacji zawodowych, uregulowań prawnych dotyczących ochrony zdrowia, ubezpieczeń społecznych oraz zasad etyki zawodowej w zakresie niezbędnym do wykonywania zawodu.

Położna, która zamierza wyjechać za granicę, np. do krajów członkowskich Unii Europejskiej w celu wykonywania zawodu składa wniosek do okręgowej rady pielęgniarek i położnych, której jest członkiem o wydanie zaświadczenia o kwalifikacjach do wykonywania zawodu położnej lub innych zaświadczeń wymaganych przez państwo przyjmujące UE. Zgodnie z art. 51 ust. 1 ustawy z dnia 15 lipca 2011 roku o zawodach pielęgniarki i położnej (tj. DzU z 2016 r., poz. 1251) okręgowa rada pielęgniarek i położnych wydaje:

- zaświadczenie stwierdzające, że pielęgniarka lub położna posiada kwalifikacje zgodne $\mathrm{z}$ wymaganiami wynikającymi z przepisów prawa Unii Europejskiej oraz że posiadany dyplom, świadectwo lub inny dokument potwierdzający posiadanie formalnych kwalifikacji odpowiada dokumentom potwierdzającym formalne kwalifikacje pielęgniarki lub położnej, wynikające z przepisów prawa Unii Europejskiej;

- zaświadczenie o przebiegu pracy zawodowej;

- inne zaświadczenia wymagane przez odpowiednie władze lub organizacje państw członkowskich Unii Europejskiej zgodnie z przepisami prawa unijnego.

Zaświadczenia powinny zostać przedłożone władzom właściwym państwa przyjmującego UE w okresie 3 miesięcy od dnia ich wydania (Zabezpieczenie, 2017).

W tabeli 4 zestawiono liczby położnych, którym w latach 2004-2016 wydano zaświadczenia o kwalifikacjach do wykonywania zawodu położnej.

Oczywiście liczba wydanych zaświadczeń przez okręgowe izby pielęgniarek i położnych nie jest tożsama z liczbą położnych, które wyjechały z kraju w celu podjęcia pracy zawodowej. Znane są przykłady, że położne, po otrzymaniu zaświadczeń nie podejmują pracy za granicą lub - po jakimś czasie - uzyskują zaświadczenie ponownie.

Kolejnym zjawiskiem obserwowanym wśród osób wyjeżdżających za granicę w celach zarobkowych jest podejmowanie pracy w domach pomocy społecznej lub w opiece długoterminowej w ramach urlopu bezpłatnego w zakładzie pracy (Binkowska-Bury, 2010, s. 497-504). Dotyczy to najczęściej osób, które nie znają w stopniu wystarczającym języka państwa przyjmującego lub nie mogą mieć uznanych kwalifikacji zgodnie z przepisami dyrektywy 2005/36/WE. Osoby te nie zgłaszają się po zaświadczenia o kwalifikacjach zawodowych lub 
zgłaszają się po nie dopiero wówczas, gdy opanowały język obcy i mogą rozpocząć procedurę uznawania kwalifikacji zawodowych.

Tabela 4. Liczba położnych, którym wydano zaświadczenia na potrzeby uznawania kwalifikacji zawodowych w okresie od 1 maja 2004 do 31 grudnia 2016 roku

\begin{tabular}{|l|c|c|c|c|}
\hline \multicolumn{1}{|c|}{ Rok } & Mgr położnictwa & $\begin{array}{c}\text { Licencjat } \\
\text { położnictwa }\end{array}$ & $\begin{array}{c}\text { Absolwenci medycznych } \\
\text { szkól zawodowych - położne }\end{array}$ & Razem \\
\hline $2004-2007$ & 24 & 57 & 670 & 751 \\
\hline 2008 & 8 & 58 & 95 & 161 \\
\hline 2009 & 12 & 33 & 74 & 119 \\
\hline 2010 & 7 & 25 & 46 & 78 \\
\hline 2011 & 20 & 32 & 45 & 97 \\
\hline 2012 & 32 & 39 & 37 & 108 \\
\hline 2013 & 34 & 36 & 28 & 98 \\
\hline 2014 & 31 & 45 & 35 & 111 \\
\hline 2015 & 35 & 43 & 23 & 71 \\
\hline 2016 & 15 & 32 & 24 & $\mathbf{1 6 9 5}$ \\
\hline Razem: & $\mathbf{2 1 8}$ & $\mathbf{4 0 0}$ & $\mathbf{1 0 7 7}$ & 101 \\
\hline
\end{tabular}

Źródło: zestawienie własne na podstawie: Zabezpieczenie (2017), tabela 17, s. 37.

Można zatem stwierdzić, że dane dotyczące liczby wydawanych zaświadczeń powinno się traktować tylko jako wskaźnik zainteresowania położnych podjęciem pracy w innych krajach członkowskich Unii Europejskiej (Wstępna, 2010).

Nie ma wprawdzie możliwości precyzyjnego ustalenia, ile położnych podjęło w minionych latach pracę poza systemem opieki zdrowotnej w Polsce, a ile z nich wyjechało za granicę - jednak wagę owego problemu przybliża zestawienie zawarte w tabeli 5. Przedstawiono w niej - dla lat 2014-2016 - liczbę absolwentów wyższych uczelni na kierunku położnictwo, liczbę absolwentów uzyskujących prawo wykonywania zawodu położnej oraz liczbę zatrudnionych absolwentów.

Analiza danych zawartych w tabeli 5 pozwala stwierdzić, iż w ostatnich latach (zapewne zjawisko to miało miejsce także wcześniej) wystąpiły znaczące różnice między liczbą absolwentów wyższych uczelni na kierunku położnictwo, liczbą absolwentów tego kierunku uzyskujących prawo wykonywania zawodu położnej oraz liczbą zatrudnionych absolwentów. 
Tabela 5. Liczba absolwentów kierunku położnictwo uzyskujących prawo wykonywania zawodu w latach 2014-2016

\begin{tabular}{|c|c|c|c|c|c|c|}
\hline \multirow[t]{2}{*}{$\begin{array}{c}\text { Rok } \\
\text { uzyskania } \\
\text { dyplomu }\end{array}$} & \multicolumn{2}{|c|}{ Liczba absolwentów* } & \multirow{2}{*}{$\begin{array}{c}\text { Liczba } \\
\text { absolwentów } \\
\text { uzyskujących } \\
\text { prawo } \\
\text { wykonywania } \\
\text { zawodu** }\end{array}$} & \multirow[t]{2}{*}{$\begin{array}{c}\text { Liczba } \\
\text { zatrudnionych } \\
\text { absolwentów }\end{array}$} & \multicolumn{2}{|c|}{$\begin{array}{c}\text { Liczba absolwentów } \\
\text { uzyskujących prawo } \\
\text { wykonywania zawodu } \\
\text { według stopnia } \\
\text { wykształcenia }\end{array}$} \\
\hline & I stopnia & II stopnia & & & licencjat & mgr \\
\hline 2014 & 1030 & 498 & 713 & 345 & 685 & 28 \\
\hline 2015 & 1049 & 539 & 592 & 198 & 563 & 29 \\
\hline 2016 & b.d. & b.d. & 492 & 107 & 474 & 18 \\
\hline Razem & & & 1797 & 650 & 1722 & 75 \\
\hline
\end{tabular}

* Ministerstwo Nauki i Szkolnictwa Wyższego dane z systemu POL-on - stan na 5 października 2016 roku. ** Centralny Rejestr Pielęgniarek i Położnych - stan na 3 marca 2017 roku.

Źródło: Zabezpieczenie (2017), tabela 3, s. 31.

Najbardziej wiarygodne jest zestawienie wielkości dotyczących absolwentów studiów I stopnia (licencjackich), bowiem absolwenci studiów II stopnia (magisterskich) mogli już uzyskać prawo wykonywania zawodu położnej po ukończeniu studiów licencjackich.

W 2014 roku studia licencjackie ukończyło 1030 osób, a tylko 685 osób otrzymało prawo wykonywania zawodu (co stanowi 66,5\% absolwentów); w 2015 roku - studia I stopnia ukończyło 1049 osób, a prawo wykonywania zawodu uzyskały tylko 563 osoby (53,7\% absolwentów).

W 2014 roku studia I i II stopnia ukończyło łącznie 1528 osób, a tylko 345 absolwentów $(22,6 \%)$ zatrudniono w sektorze opieki zdrowotnej; w 2015 roku łączna liczba absolwentów studiów licencjackich i magisterskich wyniosła 1588 osób, a zatrudniono tylko 198 osób (12,5\%).

Wobec powyższych stwierdzeń, nie dziwi zaprezentowane na wykresie 2 niekorzystne zjawisko zmian w strukturze wiekowej położnych, mających prawo wykonywania zawodu: wzrost liczebności grup położnych w średnim i starszym wieku oraz spadek udziału w populacji położnych osób młodych, generujące „starzenie się" położnych w Polsce i występowanie braku tzw. prostej zastępowalności pokoleniowej w tej grupie zawodowej.

W raporcie przygotowanym w 2010 roku przez Naczelną Radę Pielęgniarek i Położnych (Wstępna, 2010) przedstawiono m.in. porównanie liczby położnych wchodzących do systemu oraz nabywających prawa do emerytury w latach 2010-2020. 
Liczbę położnych wchodzących rocznie do systemu ochrony zdrowia oszacowano na poziomie 362 - jest to średnia liczba położnych wchodzących do systemu w 10 latach poprzedzających prognozę. Wielkość tę - taką samą dla kolejnych 11 lat - porównano z liczbą położnych, które nabędą prawo do emerytury w latach $2010-2020$.

Tabela 6. Porównanie liczby położnych wchodzących do systemu oraz nabywających prawa do emerytury w latach 2010-2020

\begin{tabular}{|l|c|c|c|}
\hline \multicolumn{1}{|c|}{ Lata } & $\begin{array}{c}\text { Liczba polożnych } \\
\text { wchodzących do systemu }\end{array}$ & $\begin{array}{c}\text { Liczba polożnych } \\
\text { mających prawo } \\
\text { do emerytury }\end{array}$ & $\begin{array}{c}\text { Stosunek liczby położnych } \\
\text { wchodzacych do systemu } \\
\text { do mających prawo do emerytury } \\
\text { (w \%) }\end{array}$ \\
\hline 2010 & 362 & 468 & 77,35 \\
\hline 2011 & 362 & 588 & 61,56 \\
\hline 2012 & 362 & 610 & 59,34 \\
\hline 2013 & 362 & 689 & 52,54 \\
\hline 2014 & 362 & 670 & 54,03 \\
\hline 2015 & 362 & 684 & 52,92 \\
\hline 2016 & 362 & 793 & 45,65 \\
\hline 2017 & 362 & 964 & 37,55 \\
\hline 2018 & 362 & 1082 & 33,46 \\
\hline 2019 & 362 & 1155 & 31,35 \\
\hline 2020 & 362 & 1096 & 33,03 \\
\hline RAZEM & $\mathbf{3 9 8 2}$ & & $\mathbf{4 5 9}$ \\
\hline
\end{tabular}

Źródło: Wstępna (2010), tabela 10, s. 18.

Według sporządzonej prognozy, w latach 2010-2020 tylko niespełna 4000 nowych położnych podejmie pracę w zawodzie, a prawie 8800 położnych nabędzie prawo do przejścia na emeryturę (położne podejmujące pracę stanowią tylko około $45 \%$ nabywających prawo do emerytury). Efektem tego będzie zatem zmniejszenie się do 2020 roku liczby pracujących w polskim systemie opieki zdrowotnej położnych o ponad 4800 osób - co stanowi ponad 20\% położnych zatrudnionych w placówkach ochrony zdrowia.

Bezrobocie wśród położnych jest stosunkowo niewielkie, np. w 2013 roku (według danych Ministerstwa Pracy i Polityki Społecznej) zarejestrowanych jako bezrobotne było 912 położnych. Bezrobocie to wynikało z braku ofert 
pracy w danym regionie (obniżanie zatrudnienia w podmiotach leczniczych z przyczyn ekonomicznych), dokonywanej restrukturyzacji podmiotów leczniczych, w wyniku której zmniejszeniu uległa liczba miejsc pracy (Zabezpieczenie, 2015b). Równocześnie wiele wskazuje na to, że owemu bezrobociu towarzyszyła pewna liczba wolnych miejsc pracy - ale w innych regionach (tzw. bezrobocie strukturalne) lub oferowane niskie wynagrodzenie nie zachęcało poszukujących pracy do jej podjęcia.

\section{Położne w Polsce - na tle innych krajów europejskich}

W porównaniach międzynarodowych są prezentowane zasoby ludzkie w systemie ochrony zdrowia w przeliczeniu na 1000, 10000 lub 100000 osób. W materiałach OECD liczba położnych jest pokazywana w przeliczeniu na 1000 mieszkańców i na 1000 żywych urodzeń.

W tabeli 7 zaprezentowano - na podstawie dostępnych danych OECD owe wskaźniki w odniesieniu do położnych mających prawo wykonywania zawodu i zatrudnionych w systemie ochrony zdrowia dla ponad 20 europejskich krajów w 2014 roku.

Liczba położnych, zarówno w przeliczeniu na 1000 osób, jak i na 1000 żywych urodzeń plasuje Polskę na jednym z czołowych miejsc w Europie.

Tabela 7. Położne mające prawo wykonywania zawodu i praktykujące w krajach europejskich (na 1000 mieszkańców i na 1000 żywych urodzeń) w 2014 roku

\begin{tabular}{|l|c|c|c|c|c|}
\hline \multirow{2}{*}{ Kraje } & \multicolumn{2}{|c|}{$\begin{array}{c}\text { Położne mające prawo } \\
\text { wykonywania zawodu }\end{array}$} & \multicolumn{3}{c|}{ Położne praktykujące } \\
\cline { 2 - 6 } & $\begin{array}{c}\text { na 1000 } \\
\text { mieszkańców }\end{array}$ & $\begin{array}{c}\text { na 1000 } \\
\text { żywych } \\
\text { urodzeń }\end{array}$ & $\begin{array}{c}\text { na 1000 } \\
\text { mieszkańców }\end{array}$ & $\begin{array}{c}\text { na 1000 } \\
\text { żywch } \\
\text { urodzeń }\end{array}$ & $\begin{array}{c}\text { jako \% mających prawo } \\
\text { wykonywania zawodu }\end{array}$ \\
\hline Austria* & 0,25 & 25,7 & 0,17 & 17,55 & 68,3 \\
\hline Belgia & 0,94 & 84,79 & & & \\
\hline Czechy & 0,57 & 54,24 & 0,41 & 39,05 & 72,0 \\
\hline Dania (2013) & 0,56 & 56,38 & 0,32 & 32,02 & 56,8 \\
\hline Estonia & 0,62 & 60,29 & 0,32 & 31,14 & 51,7 \\
\hline Finlandia (2012) & 1,03 & 93,82 & 0,42 & 38,37 & 40,9 \\
\hline Francja & & & 0,33 & 26,88 & \\
\hline Grecja* & & & 0,24 & 28,42 & \\
\hline Niemcy & & & 0,28 & 32,17 & \\
\hline Węgry & 0,56 & 58,77 & 0,17 & 17,87 & \\
\hline
\end{tabular}




\begin{tabular}{|c|c|c|c|c|c|}
\hline \multirow[b]{2}{*}{ Kraje } & \multicolumn{2}{|c|}{$\begin{array}{l}\text { Położne mające prawo } \\
\text { wykonywania zawodu }\end{array}$} & \multicolumn{3}{|c|}{ Położne praktykujące } \\
\hline & $\begin{array}{c}\text { na } 1000 \\
\text { mieszkańców }\end{array}$ & $\begin{array}{c}\text { na } 1000 \\
\text { żywych } \\
\text { urodzeń }\end{array}$ & $\begin{array}{c}\text { na } 1000 \\
\text { mieszkańców }\end{array}$ & $\begin{array}{l}\text { na } 1000 \\
\text { żywych } \\
\text { urodzeń }\end{array}$ & $\begin{array}{c}\text { jako \% mających prawo } \\
\text { wykonywania zawodu }\end{array}$ \\
\hline Wielka Brytania & & & 0,50 & 41,61 & \\
\hline Włochy & 0,32 & 38,25 & & & \\
\hline Lotwa & 0,44 & 40,28 & 0,20 & 17,98 & 44,6 \\
\hline Luksemburg & 0,67 & 61,78 & 0,35 & 32,13 & 52,0 \\
\hline Holandia (2013) & 0,22 & 21,02 & 0,18 & 17,39 & 66,3 \\
\hline Norwegia & 0,83 & 72,15 & 0,55 & 48,21 & 66,8 \\
\hline POLSKA & 0,93 & 94,54 & 0,59 & 59,66 & 63,1 \\
\hline Hiszpania & 0,18 & 20,02 & & & \\
\hline Słowenia & & & 0,07 & 6,61 & \\
\hline Szwajcaria & & & 0,30 & 28,66 & \\
\hline Szwecja (2013) & 1,19 & 100,02 & 0,75 & 63,34 & 62,6 \\
\hline Litwa & 0,39 & 37,7 & 0,31 & 29,83 & 79,1 \\
\hline
\end{tabular}

* różnice systemowe.

Źródło: zestawienie i obliczenia własne na podstawie danych z bazy OECD Health Care Resouces: Midwives, http://stats.oecd.org/Index.aspx?DatasetCode=HEALTH_STAT (dostęp: 18.08.2017).

Wykres 5. Położne mające prawo wykonywania zawodu i praktykujące na 1000 mieszkańców w krajach europejskich w 2014 roku

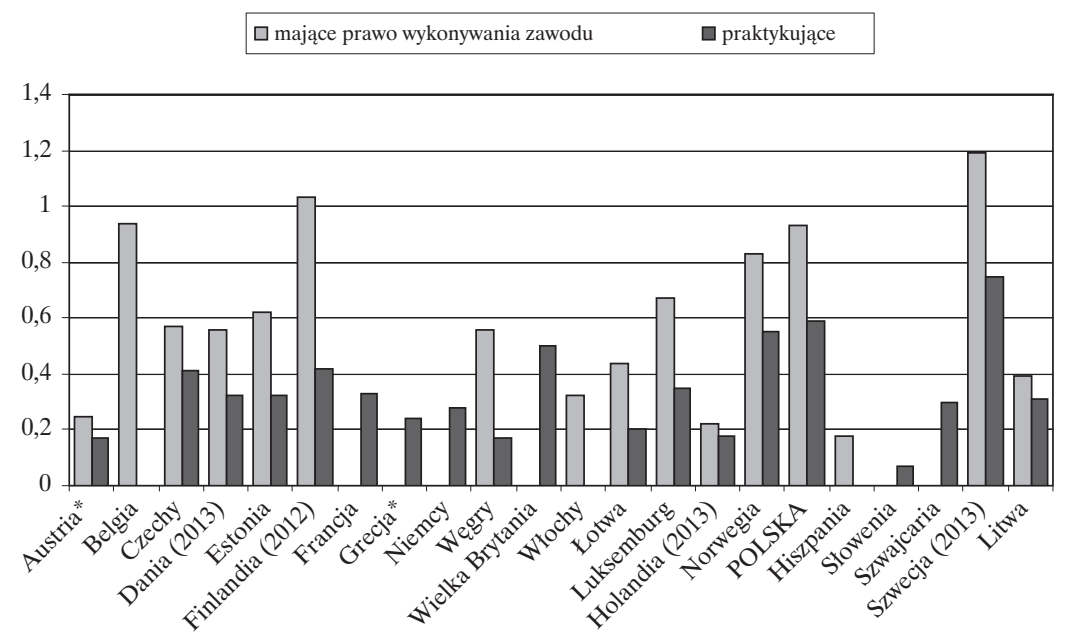

Źródło: jak w tabeli tabela 7. 
Wykres 6. Położne mające prawo wykonywania zawodu i praktykujące na 1000 żywych urodzeń w krajach europejskich w 2014 roku

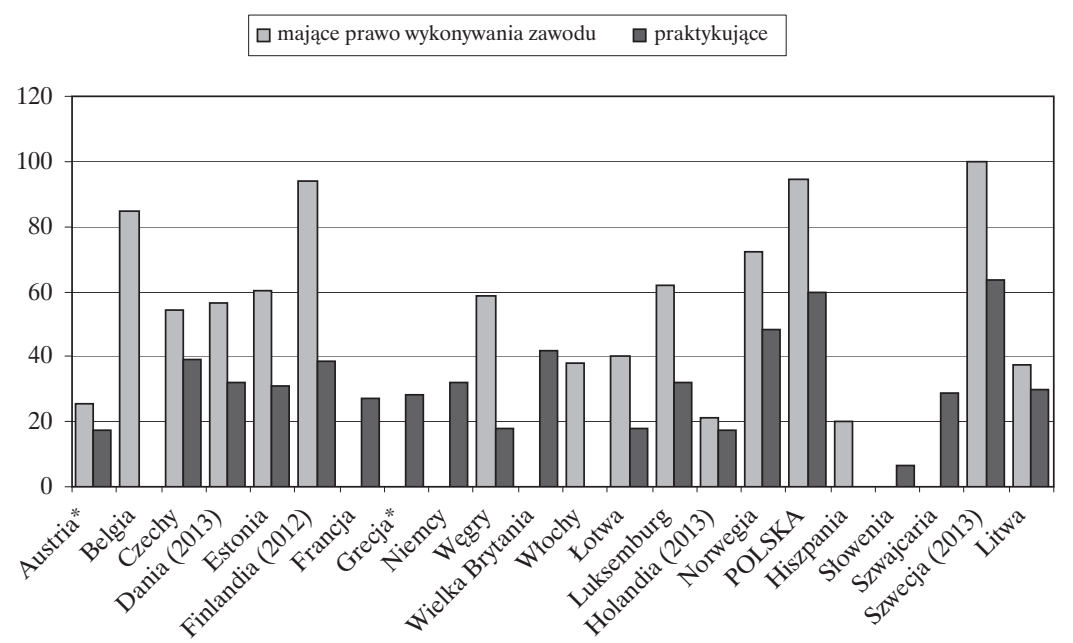

Źródło: jak w tabeli 7.

Jeśli chodzi o liczbę położnych mających prawo wykonywania zawodu - to lepszym od Polski wskaźnikiem na 1000 mieszkańców $(0,93)$ legitymują się tylko dwa kraje skandynawskie: Szwecja $(1,19)$ i Finlandia $(1,03)$.

Najwyższy wskaźnik prezentujący liczbę położnych na 1000 żywych urodzeń ma Szwecja $(100,02)$; za nią plasują się Polska $(94,54)$ i Finlandia $(93,82)$.

Najniższe oba wskaźniki mają Hiszpania ( 0,18 położnych na 1000 mieszkańców i 20 położnych na 1000 żywych urodzeń) i Holandia (0,22 na 1000 mieszkańców i 21 na 1000 żywych urodzeń).

Wskaźniki przedstawiające w 2014 roku praktykujące położne w przeliczeniu na 1000 mieszkańców i na 1000 żywych urodzeń są najwyższe dla Szwecji (0,75 na 1000 osób i 64,34 na 1000 żywych urodzeń) i dla Polski (0,59 na 1000 osób i 59,66 na 1000 żywych urodzeń). W obu wymienionych krajach występuje również zbliżony odsetek praktykujących położnych w stosunku do mających prawo wykonywania zawodu - wynosi on około $63 \%$.

Najniższe wskaźniki praktykujących położnych w przeliczeniu na 1000 mieszkańców i 1000 żywych urodzeń charakteryzowały Słowenię $(0,07$ i 6,61), Węgry (0,17 i 17,87) i Holandię (0,18 i 17,39).

Podstawowymi wskaźnikami epidemiologicznymi odzwierciedlającymi stan opieki nad kobietą w ciąży, podczas połogu oraz opieki nad niemowlęciem są: 
umieralność niemowląt (przeliczana na 1000 żywych urodzeń) oraz śmiertelność okołoporodowa matek (w przeliczeniu na 100000 urodzeń).

W tabeli 8 przedstawiono wskaźniki epidemiologiczne dla Polski i innych krajów europejskich osiągnięte w 2015 roku.

Tabela 8. Umieralność niemowląt (na 1000 żywych urodzeń) oraz śmiertelność okołoporodowa matek (na 100000 urodzeń) w krajach europejskich w 2015 roku

\begin{tabular}{|c|c|c|}
\hline Kraje & $\begin{array}{c}\text { Umieralność niemowląt } \\
\text { (na } 1000 \text { żywych urodzeń, } \\
\text { bez określenia minimalnego } \\
\text { okresu ciąży lub masy urodzeniowej) }\end{array}$ & $\begin{array}{c}\text { Śmiertelność okołoporodowa matek } \\
\text { (na } 100000 \text { urodzeń) }\end{array}$ \\
\hline Austria & 3,1 & 4,7 \\
\hline Belgia & 3,3 & - \\
\hline Czechy & 2,5 & 3,7 \\
\hline Dania & 3,7 & 0 \\
\hline Estonia & 2,5 & 0 \\
\hline Finlandia & 1,7 & 3,6 \\
\hline Francja & 3,7 & - \\
\hline Niemcy & 3,3 & 3,3 \\
\hline Grecja & 4,0 & - \\
\hline Węgry & 4,2 & 5,5 \\
\hline Irlandia & 3,4 & 1,5 \\
\hline Włochy & 2,9 & - \\
\hline Lotwa & 4,1 & 5,2 \\
\hline Luksemburg & 2,8 & 0 \\
\hline Holandia & 3,3 & 3,5 \\
\hline Norwegia & 2,3 & 0 \\
\hline POLSKA & 4,0 & 1,6 \\
\hline Portugalia & 2,9 & - \\
\hline Słowacja & 5,1 & 1,8 \\
\hline Słowenia & 1,6 & - \\
\hline Hiszpania & 2,7 & 3,6 \\
\hline Szwecja & 2,5 & 0,9 \\
\hline Szwajcaria & 3,9 & - \\
\hline Wielka Brytania & 3,9 & 4,5 \\
\hline Litwa & 4,2 & - \\
\hline
\end{tabular}

Źródło: Health Status: Maternal and infant mortality, http://stats.oecd.org/Index.aspx?DatasetCode=HEALTH_STAT (dostęp: 18.08.2017). 
Wykres 7. Liczba praktykujących położnych (na 1000 żywych urodzeń) w 2014 roku a umieralność niemowląt (na 1000 żywych urodzeń) w 2015 roku w krajach europejskich

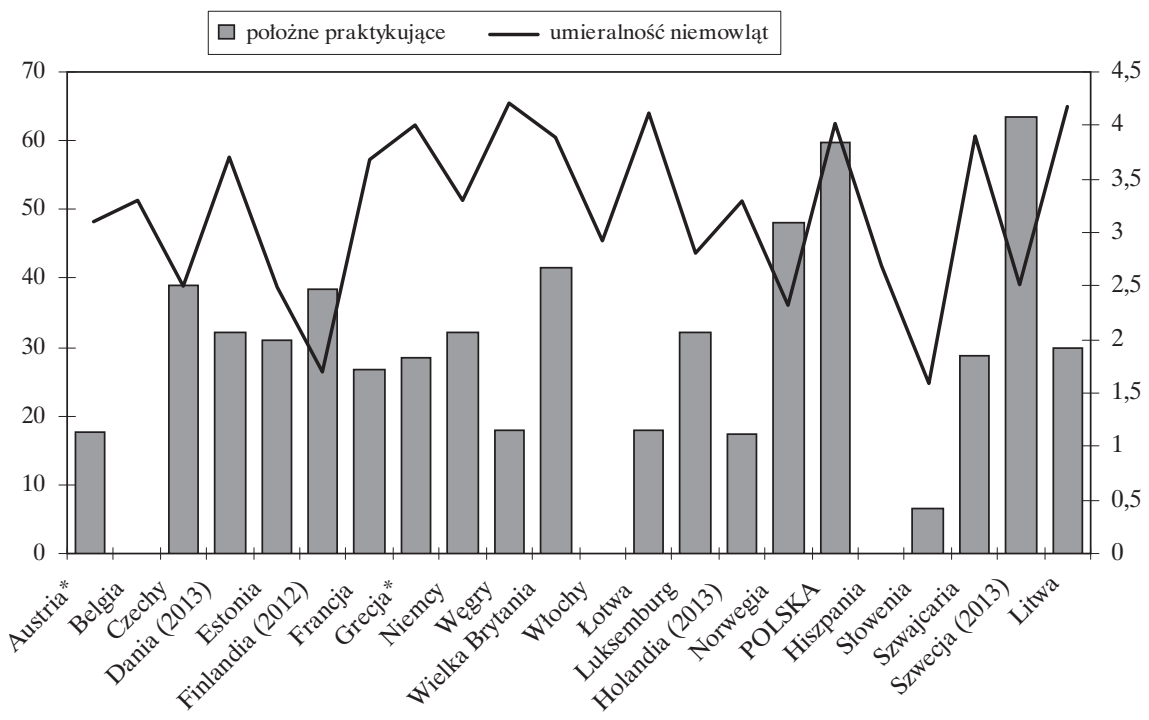

Źródło: opracowanie własne na podstawie tabel 7 i 8.

Analiza wykresu 7 pozwala na stwierdzenie, iż nie jest widoczny jednoznaczny związek między liczbą położnych a umieralnością niemowląt (oba wskaźniki prezentowane w przeliczeniu na 1000 żywych urodzeń).

\section{Podsumowanie}

Rozwiązania organizacyjne systemu ochrony zdrowia funkcjonującego w Polsce przewidują kilka możliwości opieki przedporodowej kobiet. Opiekę mogą sprawować poradnie lub gabinety opiekujące się kobietami w czasie ciąży bezpłatnie, takie jak: poradnia podstawowej opieki zdrowotnej (POZ) u lekarza rodzinnego, porady i opieka u położnej, poradnia ginekologiczno-położnicza lub poradnia przyszpitalna oraz poradnie i gabinety oferujące opiekę odpłatną, takie jak: poradnia lub gabinet prywatny - u lekarza ginekologa czy poradnia lub gabinet prywatny - u położnej.

Do położnych należy zbieranie wywiadów według obowiązującej dokumentacji, prowadzenie podstawowych badań ogólnych i tzw. badań położniczych zewnętrznych. Położne dokonują wpisów do Karty Ciąży, notują odchylenie w stanie zdrowia według Karty Czynników Ryzyka Ciążowego. Dalsze postę- 
powanie zależy od lekarza, który decyduje o badaniach szczegółowych laboratoryjnych i o dalszych wizytach. Nie zawsze położne są włączane do pełnej i systematycznej opieki przedporodowej czy do współprowadzenia ciąży, ponieważ nie zawsze współpracują one z lekarzami praktykującymi prywatnie.

Ocena jakości przedporodowej opieki położniczej jest trudna, ponieważ prawie połowa kobiet ciężarnych jest prowadzona w czasie ciąży przez lekarzy przyjmujących prywatnie.

W Polsce występuje jedna z najwyższych w Europie liczba położnych przypadająca na 1000 mieszkańców i na 1000 żywych urodzeń.

Ważnym wskaźnikiem stanu zdrowia jest współczynnik umieralności niemowląt, czyli liczba zgonów niemowląt (od 0 do 1 roku życia) w stosunku do 1000 żywo urodzonych. Umieralność niemowląt stanowi syntetyczny wskaźnik opieki okołoporodowej uznawany przez WHO i ogólnie stosowany na świecie. Umieralność wczesna (noworodkowa) stanowi 70\% ogólnej umieralności niemowląt. Przyczyną prawie 52\% zgonów niemowląt są choroby i stany okresu okołoporodowego, czyli powstające w trakcie trwania ciąży matki oraz w okresie pierwszych 6 dni życia noworodka, kolejne 34\% zgonów stanowią wady rozwojowe wrodzone, a pozostałe $14 \%$ - są powodowane chorobami nabytymi w okresie niemowlęcym lub urazami. Pomimo bardzo dużej poprawy wskaźnika umieralności niemowląt w stosunku do lat poprzednich, nadal jest on w wielu krajach postkomunistycznych, w tym również w Polsce, wysoki w porównaniu z krajami wysoko rozwiniętymi gospodarczo. Na pewno na poziom tego wskaźnika ma wpływ wiele czynników, takich jak chociażby wiek matki czy ogólny stan jej zdrowia, obecność chorób przewlekłych, poziom życia, edukacja matki i czynniki środowiskowe. Jednak niewątpliwie wysoka jakość i sprawna organizacja opieki medycznej i szybka dostępność do wykwalifikowanego personelu medycznego może mieć wpływ na poziom wskaźnika umieralności niemowląt. Wciąż jeszcze występujące trudności z dostępem do kosztownych technologii medycznych, jakie są niezbędne w profilaktyce, diagnostyce, leczeniu i rehabilitacji noworodków przedwcześnie urodzonych, może być wytłumaczeniem relatywnie wysokiego poziomu wskaźnika umieralności niemowląt w krajach postkomunistycznych (Szamotulska, 2010, s. 113-128).

W badaniach demograficznych przeprowadzonych w Polsce przez Małgorzatę Szczyt (2012) wykazano, że im większa liczba pacjentów przypada na jednego lekarza i im niższe są przeciętne wydatki gospodarstw domowych, tym wyższy jest wskaźnik umieralności niemowląt. Z kolei wyższe wartości liczby urodzeń przypadające na położną powodują spadek umieralności niemowląt w województwach ogółem i w przekrojach miast, natomiast wzrost w przekrojach wsi. 
W Szwecji liczba położnych przypadająca na 1000 mieszkańców i na 1000 żywych urodzeń jest tylko minimalnie wyższa niż w Polsce, natomiast istnieje wyraźna różnica we wskaźniku umieralności niemowląt na 1000 żywych urodzeń i we wskaźniku śmiertelności okołoporodowej matek.

Przedstawione dane wskazują na konieczność przeprowadzenia dalszych wnikliwych ocen i analiz dotyczących czynników mogących mieć wpływ na umieralność niemowląt i śmiertelność okołoporodową matek. Na pewno jednym z tych czynników jest organizacja i jakość opieki nad kobietą ciężarną, opieki przedporodowej oraz właściwe umiejscowienie położnej w tej opiece. Jednocześnie należy dokładnie przeanalizować liczbę położnych pracujących w zawodzie z uwzględnieniem ich wieku. Dostosowanie liczby absolwentów położnictwa do realnych potrzeb $\mathrm{w}$ tym zakresie - $\mathrm{z}$ uwzględnieniem ruchów migracyjnych i starzenia się kadry położnych - stanowi kolejne, bardzo ważne wyzwanie dla decydentów.

\section{Bibliografia}

Binkowska-Bury, M., Nagórska, M., Januszewicz, P. i Ryżko, J. (2010). Migracje pielęgniarek i położnych - problemy i wyzwania. Przegląd Medyczny Uniwersytetu Rzeszowskiego i Narodowego Instytutu Leków w Warszawie (4).

Biuletyn Statystyczny Ministerstwa Zdrowia z lat 2011-2016. Warszawa: Centrum Systemów Informacyjnych Ochrony Zdrowia, www.csioz.gov.pl (dostęp: 18.06.2017).

Iwanowicz-Palus, G., Bień, A. i Golonka, E. (2013). Położna w Zjednoczonej Europie. Problemy Pielegniarstwa 21(1).

Karkowski, T. (2015). Dostosowywanie zasobów kadry medycznej do potrzeb starzejącego się społeczeństwa. Zdrowie Publiczne i Zarzadzanie 13(1).

Monitorowanie migracji polskich lekarzy, pielegniarek i potożnych po przystapieniu Polski do Unii Europejskiej. Raport z realizacji programu w 2006 r., http://www.mz. gov.pl/wwwmz/ index?mr $=\& \mathrm{~ms}=\& \mathrm{ml}=\mathrm{pl} \& \mathrm{mi}=565 \& \mathrm{mx}=0 \& \mathrm{ma}=7876$ (dostęp: 18.06.2017).

OECD Health Care Resources: Midwives, http://stats.oecd.org/Index. aspx?DatasetCode=HEALTH_STAT (dostęp: 18.06.2017).

Roczne wskaźniki makroekonomiczne. Warszawa: Główny Urząd Statystyczny, http://stat.gov. pl/wskazniki-makroekonomiczne/ (dostęp: 18.06.2017).

Szamotulska, K. (2010). Stan zdrowia matek i dzieci w okresie okołoporodowym w Polsce na tle krajów Unii Europejskiej. Opracowanie na podstawie wskaźników Euro-Peristat. Medycyna Wieku Rozwojowego XIV(2).

Szczyt, M. (2012). Przestrzenne zróżnicowanie umieralności niemowlą w Polsce $w$ latach 1997 - 2004. Zastosowania metod statystycznych $w$ badaniach naukowych IV. StatSoft Polska.

Włodarczyk, W.C., Domagała, A. (2011). Kadry medyczne opieki zdrowotnej. Niektóre problemy, postulowane działania. Zarzadzanie Zasobami Ludzkimi (2).

Wstępna ocena zasobów kadrowych pielęniarek i położnych w Polsce do roku 2020 (2010). Warszawa: Naczelna Rada Pielęgniarek i Położnych, czerwiec.

Zabezpieczenie społeczeństwa polskiego w świadczenia pielęgniarek i położnych. Raport Naczelnej Rady Pielęgniarek i Potożnych (2015a). Warszawa, maj. 
Zabezpieczenie społeczeństwa polskiego $w$ świadczenia pielęgniarek i położnych. Rekomendacje $i$ ich realizacja (2015b). Warszawa: Ministerstwo Zdrowia, Departament Pielęgniarek i Położnych, 31 sierpnia.

Zabezpieczenie spoteczeństwa polskiego w świadczenia pielęgniarek i położnych, Raport Naczelnej Rady Pielegniarek i Położnych (2017). Warszawa, marzec.

Zybała, A. (red.) (2009). Wyzwania w systemie ochrony zdrowia - zasoby ludzkie i zasoby organizacyjne w centralnych instytucjach. Raport na zlecenie Światowej Organizacji Zdrowia. Warszawa: KSAP. 



\title{
Ochrona danych osobowych dotyczących zdrowia $w$ świetle zmian wprowadzanych przez rozporządzenie 2016/679
}

\begin{abstract}
Streszczenie
Od 25 maja 2018 roku zaczęło być stosowane rozporządzenie Parlamentu Europejskiego i Rady (UE) 2016/679 z 27 kwietnia 2016 roku w sprawie ochrony osób fizycznych w związku z przetwarzaniem danych osobowych i w sprawie swobodnego przepływu takich danych oraz uchylenia dyrektywy 95/46/WE (ogólne rozporządzenie o ochronie danych). Rozporządzenie wprowadza wiele zmian prawnych do przepisów o ochronie danych osobowych, w tym danych dotyczących zdrowia, które mają odpowiadać na postęp technologiczny i następujące zmiany społeczno-gospodarcze. Rozporządzenie wprowadza definicję danych o stanie zdrowia, nowelizuje przepisy dotyczące przesłanek uchylających zakaz przetwarzania szczególnych kategorii danych, do których zaliczają się dane dotyczące zdrowia, oraz zawiera szereg regulacji, np. w zakresie oceny skutków dla ochrony danych czy powołania inspektora ochrony danych osobowych, odnoszących się do tej kategorii danych osobowych.
\end{abstract}

Słowa kluczowe: dane dotyczące zdrowia, ochrona danych osobowych, RODO.

\section{Protection of Personal Data Concerning Health (As Changed by Regulation 2016/679)}

\footnotetext{
Abstract

From 25 May 2018, Regulation (EU) 2016/679 of the European Parliament and of the Council of 27 April 2016 on the protection of natural persons with regard to the processing of personal

1 Natalia Kalinowska - mgr, doktorantka na Wydziale Prawa i Administracji Uniwersytetu Kardynała Stefana Wyszyńskiego w Warszawie, prawnik w kancelarii Maruta Wachta, e-mail: nm.kalinowska@gmail.com.
} 
data and on the free movement of such data, and repealing Directive 95/46/EC (Ceneral Data Protection Regulation) will be applicable. The Regulation introduces many legal changes to the provisions on the protection of personal data, including data concerning health, which take into account technological progress and the following socio-economic changes. The Regulation introduces a definition of data concerning health, revises provisions regarding the grounds for repealing the ban on the processing of special categories of data which include data concerning health and contains a number of provisions (regarding these categories of personal data), e.g., in the area of data protection impact assessment or the appointment of a data protection officer.

Keywords: data concerning health, personal data protection, GDPR.

\section{Wstęp}

14 kwietnia 2016 roku Parlament Europejski przyjął rozporządzenie w sprawie ochrony osób fizycznych w związku z przetwarzaniem danych osobowych i w sprawie swobodnego przepływu takich danych (ogólne rozporządzenie o ochronie danych) ${ }^{2}$. Tym samym zakończyły się czteroletnie prace organów unijnych nad przygotowaniem powyższej regulacji. Rozporządzenie (zwane również RODO) zastąpi obowiązującą od 1995 roku dyrektywę 95/46/WE 3 . Rozporządzenie kontynuuje podejście opierające się na podziale danych na dane osobowe zwykłe (choć nigdzie nie nazywa ich w ten sposób) oraz dane osobowe szczególnie chronione (zwane także wrażliwymi, sensytywnymi). Do szczególnych kategorii danych zaliczają się m.in. dane dotyczące zdrowia. Niniejszy artykuł stanowi analizę zmian wprowadzanych przez rozporządzenie 2016/679 w kontekście danych dotyczących zdrowia. Wskazane zostaną podobieństwa i różnice w stosunku do obecnie obowiązującej ustawy ${ }^{4}$, przeanalizowana zostanie definicja danych dotyczących zdrowia oraz zmiana wymogów dotyczących zgody na przetwarzanie szczególnych kategorii danych z pisemnej na zgodę wyraźną, która będzie miała doniosłe znaczenie z perspektywy praktycznej.

2 Rozporządzenie Parlamentu Europejskiego i Rady (UE) 2016/679 z dnia 27 kwietnia 2016 roku w sprawie ochrony osób fizycznych w związku z przetwarzaniem danych osobowych i w sprawie swobodnego przepływu takich danych oraz uchylenia dyrektywy 95/46/WE (ogólne rozporządzenie o ochronie danych).

3 Dyrektywa 95/46/WE Parlamentu Europejskiego i Rady z dnia 24 października 1995 roku w sprawie ochrony osób fizycznych w zakresie przetwarzania danych osobowych i swobodnego przepływu tych danych.

4 Ustawa z dnia 29 sierpnia 1997 roku o ochronie danych osobowych. DzU z 1997 r., nr 133 poz. 883. 


\section{Historyczne przyczyny uchwalenia rozporządzenia}

Ogólne rozporządzenie o ochronie danych weszło w życie 24 maja 2016 roku, a jego stosowanie wyznaczono na 25 maja 2018 roku. Ustawodawca europejski przewidział długi - dwuletni okres karencji, aby podmioty przetwarzające dane osobowe mogły lepiej przygotować się na nadchodzące zmiany. Opublikowany na stronie Rządowego Centrum Legislacji 14 września 2017 roku projekt ustaw o ochronie danych osobowych ${ }^{5}$, wraz z przepisami wprowadzającymi ustawę o ochronie danych osobowych ${ }^{6}$, przewiduje zmianę aż 133 ustaw. Opracowanie nowej ustawy było konieczne, ponieważ mimo iż dotychczasowa ustawa częściowo zawierała regulacje analogiczne do regulacji rozporządzenia, np. w zakresie definicji danych osobowych, to jednak były w niej zawarte także przepisy uregulowane odmienne (choćby w zakresie definicji zgody osoby, której dane dotyczą) oraz regulacje, których w ogóle nie przewiduje rozporządzenie, np. w zakresie rejestracji zbiorów danych, natomiast regulacja unijna wprowadza nowe wymogi, np. obowiązek zgłaszania naruszeń, uregulowania dotyczące oceny skutków dla ochrony danych osobowych czy certyfikacji ${ }^{7}$.

Jeśli porówna się początki ochrony danych w Europie oraz standard, który wprowadza rozporządzenie ogólne, widać wyraźnie ile wysiłku na przestrzeni lat włożono w to, aby poprzez wprowadzenie przepisów o ochronie danych osobowych zagwarantować należytą ochronę prawa do prywatności. Jest to szczególnie istotne w kontekście danych osobowych przetwarzanych w systemach informatycznych z dostępem do sieci publicznej.

Początki europejskiego prawa ochrony danych osobowych sięgają lat 70. XX wieku. To właśnie wtedy pojawiły się pierwsze (lokalne) ustawy o ochronie danych osobowych m.in. w Niemczech, Szwecji czy we Francji (por. Barta, Fajgielski, Markiewicz, 2015, s. 23). W 1981 roku uchwalono Konwencję 108 Rady Europy ${ }^{8}$ - pierwszy akt prawny, który był i nadal pozostaje jedynym, prawnie wiążącym dokumentem o zasięgu międzynarodowym dotyczącym ochrony danych osobowych, którego celem było ,zagwarantowanie [...] każdej osobie fizycznej [...] poszanowania jej praw i podstawowych wolności,

5 Projekt ustawy o ochronie danych osobowych, https://legislacja.rcl.gov.pl/docs//2/12302950/12 457664/12457665/dokument308361.pdf (dostęp: 22.11.2017).

6 Projekt ustawy - Przepisy wprowadzające ustawę o ochronie danych osobowych, https://legislacja.rcl.gov.pl/docs//2/12302951/12457706/12457707/dokument308373.pdf (dostęp: 22.11.2017).

7 Por. Uzasadnienie do projektu ustawy o ochronie danych osobowych, https://legislacja.rcl. gov.pl/docs//2/12302950/12457664/12457665/dokument308360.pdf (dostęp: 26.11.2017).

8 Konwencja nr 108 Rady Europy o ochronie osób w związku z automatycznym przetwarzaniem danych osobowych, sporządzona w Strasburgu dnia 28 stycznia 1981 roku. 
w szczególności prawa do prywatności, w związku z automatycznym przetwarzaniem jej danych osobowych". W następnych latach pojawiało się w Europie coraz więcej krajowych ustaw dotyczących ochrony danych osobowych. Ta wielość odmiennych, lokalnych regulacji zestawiona z pogłębiającą się integracją europejską oraz postępem technologicznym zintensyfikowała potrzebę ujednolicenia prawa ochrony danych osobowych w Unii Europejskiej i w 1995 roku uchwalono dyrektywę 95/46/WE 9 . W treści dyrektywy, w motywie 8 wskazano, że celem jej uchwalenia było zniesienia przeszkód w przepływie danych osobowych. Wskazano, że drogą do realizacji tego celu jest zrównanie stopnia ochrony praw i swobód jednostki w zakresie przetwarzania tych danych we wszystkich państwach członkowskich.

Od dłuższego czasu dostrzegano również potrzebę rewizji przepisów dyrektywy 95/46/WE ${ }^{10}$. Twórcy dyrektywy, tworząc ją w latach $90 \mathrm{XX}$ wieku, nie mogli przewidzieć wielu istotnych dla ochrony danych osobowych wydarzeń - przemian społeczno-gospodarczych (np. globalizacji) oraz tak szybkiego rozwoju nowych technologii, które miały wpływ na nowe sposoby przetwarzania danych osobowych. Dlatego regulacja uchwalona ponad 20 lat temu nie przystawała do obecnych czasów i nie zapewniała już wystarczającej ochrony ani w zakresie praw osób, których dane dotyczą, ani sposobów zabezpieczenia dostępu do danych ${ }^{11}$. Ponadto, dyrektywa była aktem obowiązującym pośrednio, wymagającym implementacji. Tworzyła tylko pewne ramy i standardy. W następstwie tego, w krajach członkowskich przepisy odnoszące się do ochrony danych osobowych nadal są w pewnym stopniu zróżnicowane, co utrudnia funkcjonowanie na rynku przedsiębiorcom, którzy w ramach swojej działalności przetwarzają dane osobowe w wielu krajach członkowskich.

Rozporządzenie to akt prawny bezpośrednio obowiązujący, dlatego będzie miał bezpośrednie zastosowanie we wszystkim państwach członkowskich Unii Europejskiej. Cele rozporządzenia są zbieżne z celami dyrektywy - przede wszystkim jest to zapewnienie w całej Unii spójnego i jednolitego poziomu ochrony danych osób fizycznych, tak aby umożliwić swobodny przepływ danych

9 Dyrektywa 95/46/WE Parlamentu Europejskiego i Rady z dnia 24 października 1995 roku w sprawie ochrony osób fizycznych w zakresie przetwarzania danych osobowych oraz swobodnego przepływu tych danych (Dz.Urz. WE L 281 z 23.11.1995 r.).

10 Już w 2010 roku wydano komunikat Komisji do Parlamentu Europejskiego, Rady, Europejskiego Komitetu Ekonomiczno-Społecznego oraz Komitetu Regionów „Całościowe podejście do kwestii ochrony danych osobowych w Unii Europejskiej".

11 Por. motywy 9 i 10, Rozporządzenie Parlamentu Europejskiego i Rady (UE) 2016/679 z dnia 27 kwietnia 2016 roku w sprawie ochrony osób fizycznych w związku z przetwarzaniem danych osobowych i w sprawie swobodnego przepływu takich danych oraz uchylenia dyrektywy 95/46/WE. 
osobowych w Unii Europejskiej oraz ułatwić funkcjonowanie przedsiębiorstw na jednolitym rynku.

W konsekwencji wszystkie państwa członkowskie UE będą stosowały przepisy wyżej wymienionego rozporządzenia ${ }^{12}$. Z uwagi jednak na odmienności porządków i tradycji prawnych państw członkowskich rozporządzenie dopuszcza doprecyzowanie pewnych kwestii w prawie krajowym.

Znaczącą różnicą, którą wprowadza rozporządzenie, jest podejście oparte na ryzyku. Ryzyko (często stopniowane) naruszenia praw i wolności osób, których dane dotyczą, na gruncie rozporządzenia 2016/679, staje się jednym z kluczowych pojęć. Administrator oraz w różnym zakresie podmiot przetwarzający muszą brać pod uwagę istniejące i potencjalne ryzyka dla ochrony danych osobowych, by zastosować odpowiednie do nich rozwiązania. Takie podejście umożliwia skoncentrowanie się na sytuacjach najwyższego ryzyka, przy jednoczesnym zachowaniu odpowiedniego poziomu ochrony, gdy to ryzyko jest niskie i nie wymaga wykorzystywania całego instrumentarium środków przewidzianych przez ogólne rozporządzenie (Bielak-Jomaa, Lubasz, 2018, s. 341). Takie proaktywne podejście do ochrony danych osobowych odchodzi od znanego z ustawy podejścia opartego na drobiazgowej regulacji zabezpieczenia danych często odstającej od zakresu, kontekstu czy celów ich przetwarzania, nie gwarantując właściwego stopnia ochrony.

\section{Dane osobowe dotyczące zdrowia na gruncie dyrektywy i ustawy}

Zgodnie z definicją zawartą w art. 2 pkt a) dyrektywy, dane osobowe to wszelkie informacje dotyczące zidentyfikowanej lub możliwej do zidentyfikowania osoby fizycznej („osoby, której dane dotyczą”); osoba możliwa do zidentyfikowania to osoba, której tożsamość można ustalić bezpośrednio lub pośrednio, szczególnie przez powołanie się na numer identyfikacyjny lub jeden bądź kilka szczególnych czynników określających jej fizyczną, fizjologiczną, umysłową, ekonomiczną, kulturową lub społeczną tożsamość.

Definicja zawarta w art. 6 ustawy stanowi natomiast, że: „za dane osobowe uważa się wszelkie informacje dotyczące zidentyfikowanej lub możliwej do zidentyfikowania osoby fizycznej [...] Osobą możliwą do zidentyfikowania jest osoba, której tożsamość można określić bezpośrednio lub pośrednio, w szczególności przez powołanie się na numer identyfikacyjny albo jeden lub kilka specyficznych czynników określających jej cechy fizyczne, fizjologiczne, umy-

12 Ocena skutków regulacji - Projekt ustawy o ochronie danych osobowych, s. 3, https://legislacja. rcl.gov.pl/docs//2/12302950/12457664/12457665/dokument308359.pdf (dostęp: 24.11.2017). 
słowe, ekonomiczne, kulturowe lub społeczne. [...] Informacji nie uważa się za umożliwiającą określenie tożsamości osoby, jeżeli wymagałoby to nadmiernych kosztów, czasu lub działań".

Obie definicje nieznacznie się od siebie różnią, ale różnice te nie wpływają, co do zasady, na zakres znaczeniowy tego pojęcia.

Definicja danych osobowych w polskiej ustawie, w jej pierwotnym kształcie brzmiała inaczej, uznając za dane osobowe „każdą informację dotyczącą osoby fizycznej, pozwalającą na określenie tożsamości tej osoby”. Taka redakcja przepisu spotkała się z krytyką nauki prawa - zarzucano, że była niezgodna $z$ dyrektywą 95/46/WE, jako że za dane osobowe uznawała wyłącznie tzw. dane identyfikacyjne (por. Sibiga, 2003, s. 32; Barta, Litwiński, 2015, s. 75). Takie stanowisko zostało jednak słusznie poddane krytyce w nauce prawa, jako że za dane osobowe powinny zostać uznane wszelkie informacje, ,jeżeli tylko możliwe jest ich odniesienie do konkretnej osoby" (por. Barta, Fajgielski, Markiewicz, 2015, s. 383-384; Barta, Litwiński, 2015, s. 75).

Szczególnym typem danych osobowych są tzw. dane osobowe wrażliwe, sensytywne. Ustawa wskazuje, że zaliczane są do nich „dane ujawniające: pochodzenie rasowe lub etniczne, poglądy polityczne, przekonania religijne lub filozoficzne, przynależność wyznaniową, partyjną lub związkową, jak również dane o stanie zdrowia, kodzie genetycznym, nałogach lub życiu seksualnym oraz dane dotyczące skazań, orzeczeń o ukaraniu i mandatów karnych, a także innych orzeczeń wydanych w postępowaniu sądowym lub administracyjnym". Przepis polskiej ustawy wykracza poza zakres pojęcia danych sensytywnych ukształtowany w dyrektywie 95/46/WE, obejmując szczególną ochroną również informacje o kodzie genetycznym i nałogach (por. Kulesza, 2000, nr 5; Barta, Litwiński, 2015, s. 308). Przetwarzanie tych danych jest co do zasady zakazane, jednakże istnieje wiele wyjątków od tego zakazu ujętych w art. 27 ust. 2 ustawy.

Katalog danych szczególnie chronionych „ma charakter taksatywny, dlatego nie istnieje możliwość poszerzenia go o dalsze kategorie danych, nawet gdyby wydawało się to uzasadnione, jak choćby w przypadku danych dotyczących adopcji. Nie zmienia to faktu, że w niektórych przypadkach mogą powstawać niejasności, czy dana informacja, którą da się powiązać z określoną osobą, ujawnia np. jej przekonania religijne lub polityczne bądź pozwala zorientować się o pochodzeniu rasowym lub etnicznym" (Barta, Fajgielski, Markiewicz, 2015, s. 486).

Nie ma wątpliwości, iż specyfika danych wrażliwych jako odnoszących się do sfery prywatności czy nawet intymności człowieka sprawia, iż konieczne jest zastosowanie szczególnych standardów ochrony w procesach przetwarzania tych informacji (Bielak-Jomaa, Lubasz, 2018, s. 278). 
Wskazuje się także, że dane wrażliwe, w przeciwieństwie do pozostałych, wiążą się ze znacznie większym poczuciem zagrożenia oraz niebezpieczeństwem wywołania na różnych polach (zatrudnienie, ubezpieczenie, kredytowanie itd.) decyzji dyskryminacyjnych.

W doktrynie podnosi się jednak, że nie zawsze jest jasne, czy dany rodzaj informacji powinien być zaliczany do danych szczególnie wrażliwych -mogą się pojawiać wątpliwości, czy pewne wiadomości (np. o tym, że ktoś używa okularów) powinny być poddane wzmożonej ochronie jako dane wrażliwe. Podobnie można się odnieść do informacji, że określona osoba pali fajkę lub papierosy, choć mamy tu do czynienia z nałogiem (Barta, Fajgielski, Markiewicz, 2015, s. 487).

Ani w dyrektywie, ani w polskiej ustawie nie znalazła się definicja danych dotyczących zdrowia, mimo że oba akty prawne odwołują się do tej kategorii. Ponadto, do tej pory w polskiej ustawie o ochronie danych osobowych i dyrektywie 95/46/WE (zarówno w polskiej, jak i w angielskiej wersji językowej) używano nawet różnych terminów na jej określenie - w polskich przepisach posługiwano się pojęciem „dane o stanie zdrowia”, a w dyrektywie „dane dotyczące zdrowia”.

Próbując odpowiedzieć na pytanie o zależności między tymi pojęciami, warto odnieść się do rekomendacji R(97)5 Komitetu Ministrów do Państw Członkowskich dotyczącej ochrony danych medycznych ${ }^{13}$, w której te terminy funkcjonowały niejako zamiennie. Ponadto, rekomendacja R(97)5 nie tylko zrównywała znaczenie pojęć „dane o stanie zdrowia” i „dane dotyczące zdrowia”, ale stawiała je na równi z „danymi medycznymi”" ${ }^{4}$. Potwierdzenie takiego podejścia można znaleźć również w polskiej doktrynie - podkreśla się, że mimo, iż relacja „danych dotyczących zdrowia” i „danych medycznych” nie jest jasna, to w praktyce te pojęcia mogą się zacierać (por. Wąsik, 2015).

W polskiej literaturze naukowej, próbując definiować pojęcie „dane o stanie zdrowia" wskazywano, na trudność interpretacyjną w tym zakresie. Paweł

13 Recommendation No R (97) 5 of the Committee of Ministers to Member States on the protection of medical data (Adopted by the Committee of Ministers on 13 February 1997 at the 584th meeting of the Ministers' Deputies), https:/www.google.pl/url?sa=t\&rct=j\&q $=\& \mathrm{esrc}=\mathrm{s} \&$ source $=$ web $\& \mathrm{~cd}=1 \& \mathrm{cad}=$ rja $\&$ uact $=8 \& \mathrm{ved}=0$ ahUKEwjq50OO0eHXAhWJIOw KHRqnDaMQFggqMAA\&url=https $\% 3 \mathrm{~A} \% 2 \mathrm{~F} \% 2 \mathrm{Frm}$. coe.int $\% 2 \mathrm{FCoERMPublicCommonSe}$ archServices\%2FDisplayDCTMContent\%3FdocumentId\%3D09000016806af967\&usg =AOvV aw2acyV-MKt3tPhMKpE7yAMD (dostęp: 26.11.2017).

14 Nie tylko zamiennie się ich używa - dane osobowe medyczne (w tytule), dane dotyczące zdrowia lub dane o stanie zdrowia (w treści); ale w definicji danych dotyczących zdrowia to pojęcie w wersji angielskiej jest tłumaczone jako medical data. 
Barta i Paweł Litwiński wprost wskazują, że z jednej strony informacja o tym, że komuś nic nie dolega, może być potraktowana jako informacja o stanie zdrowia (np. w przypadku oceny stanu zdrowia w trakcie badań nad jakimś produktem leczniczym), z drugiej zaś strony informacja o częstotliwości odwiedzin u swojego lekarza pierwszego kontaktu nie musi bezpośrednio odnosić się do stanu zdrowia osoby (osoba może po prostu czuć potrzebę częstych wizyt u lekarza, mimo że jej nic nie dolega) (Barta, Litwiński, 2015, s. 309). Niemniej jednak zgodnie $\mathrm{z}$ art. 27 ust. 2 pkt 7, dopuszczalne jest przetwarzanie danych wrażliwych (w tym danych o stanie zdrowia), jeśli te dane są „przetwarzane w celu ochrony stanu zdrowia, świadczenia usług medycznych lub leczenia pacjentów przez osoby trudniące się zawodowo leczeniem lub świadczeniem innych usług medycznych, zarządzania udzielaniem usług medycznych i są stworzone pełne gwarancje ochrony danych osobowych".

Jak zauważają Janusz Barta, Paweł Fajgielski i Ryszard Markiewicz przez pojęcie ochrony stanu zdrowia, leczenia i świadczenia usług medycznych należy rozumieć także działania profilaktyczne, diagnostyczne, rehabilitacyjne (w tym kuracyjne); zatem jest dopuszczalne przetwarzanie danych o stanie zdrowia pacjenta również przez te podmioty medyczne, które uczestniczą w kierowaniu pacjenta na leczenie uzdrowiskowe. Natomiast osoby trudniące się zawodowo leczeniem lub świadczeniem innych usług medycznych to „personel medyczny", który tworzą - jak uważamy - nie tylko sami lekarze, ale również personel pomocniczy: pielęgniarki i laboranci oraz rehabilitanci (Barta, Fajgielski, Markiewicz, 2015, s. 498).

Niewątpliwie do kategorii danych o stanie zdrowia należy zaliczyć dane z dokumentacji medycznej. Wskazuje się także, że sama informacja o prowadzeniu dokumentacji medycznej dla określonej osoby może być uznana za dane o stanie jej zdrowia. Podobne stanowisko zostało wyrażone przez Grupę Roboczą ds. Ochrony Danych (Grupa Robocza) ${ }^{15}$ - wszelkie dane zawarte w dokumentacji medycznej należy traktować jako dane szczególnie chronione, które podlegają nie tylko ogólnym zasadom dotyczącym ochrony danych osobowych określonym w dyrektywie, lecz także szczególnym zasadom dotyczącym ochrony danych osobowych, mającym zastosowanie do przetwarzania informacji szczególnie chronionych. Generalnie wszelkie dane zawarte w dokumentacji medycznej należy traktować jako dane osobowe szczególnie chronione. Treścią dokumentacji medycznej są zatem dane osobowe, i to dotyczące najwrażliw-

15 Grupa Robocza została powołana na mocy art. 29 dyrektywy 95/46/WE. Jest ona niezależnym europejskim organem doradczym w zakresie ochrony danych i prywatności. 
szych sfer prywatności każdego człowieka. Obok danych o stanie zdrowia mogą to być dane genetyczne, dane o seksualności, dane o nałogach, a nawet dane określające przekonania religijne czy przynależność wyznaniową, np. gdy określony pacjent $\mathrm{z}$ uwagi na przekonania odmawia zgody na wykonanie określonego zabiegu (Krasińska, 2016).

Prowadzenie dokumentacji medycznej stanowi jeden z obowiązków podmiotów udzielających świadczeń zdrowotnych i zgodnie z ustawą o prawach pacjenta i Rzeczniku Praw Pacjenta ${ }^{16}$, dane osobowe pacjenta zawarte w dokumentacji medycznej podlegają ochronie określonej w tej ustawie oraz w przepisach odrębnych (m.in. ustawie o ochronie danych osobowych).

Zgodnie z art. 25 ustawy dokumentacja medyczna zawiera co najmniej:

1) oznaczenie pacjenta, pozwalające na ustalenie jego tożsamości:

a. nazwisko i imię (imiona),

b. datę urodzenia,

c. oznaczenie płci,

d. adres miejsca zamieszkania,

e. numer PESEL, jeżeli został nadany, w przypadku noworodka - numer PESEL matki, a w przypadku osób, które nie mają nadanego numeru PESEL - rodzaj i numer dokumentu potwierdzającego tożsamość,

f. w przypadku gdy pacjentem jest osoba małoletnia, całkowicie ubezwłasnowolniona lub niezdolna do świadomego wyrażenia zgody - nazwisko i imię (imiona) przedstawiciela ustawowego oraz adres jego miejsca zamieszkania;

2) oznaczenie podmiotu udzielającego świadczeń zdrowotnych ze wskazaniem komórki organizacyjnej, w której udzielono świadczeń zdrowotnych;

3) opis stanu zdrowia pacjenta lub udzielonych mu świadczeń zdrowotnych;

4) datę sporządzenia.

Przepisy ustawy wskazują ponadto, że w dokumentacji medycznej zamieszcza się także informację o wydaniu opinii albo orzeczenia wydanego przez lekarza.

Inną ustawą odnoszącą się do danych dotyczących zdrowia jest ustawa o systemie informacji w ochronie zdrowia ${ }^{17}$. W ustawie tej wskazuje się niejako na dwie kategorie danych - dane osobowe, ujęte w art. 4 ust. 3 pkt 1 oraz jednostkowe dane medyczne.

16 Ustawa z dnia 6 listopada 2008 roku o prawach pacjenta i Rzeczniku Praw Pacjenta. DzU z 2017 r. poz. 1318 t.j. z późn. zm.

17 Ustawa z dnia 28 kwietnia 2011 roku o systemie informacji w ochronie zdrowia. DzU z 2017 r. poz. 1845 t.j. z późn. zm. 
Dane osobowe są enumeratywnie wyliczone i ich zakres jest ograniczony treścią pkt 1: „Do danych osobowych zaliczamy: a) imię (imiona) i nazwisko, b) nazwisko rodowe, c) płeć, d) obywatelstwo, e) (uchylona) f) wykształcenie, g) numer PESEL, h) datę urodzenia, i) w przypadku osób, które nie mają nadanego numeru PESEL - numer paszportu albo innego dokumentu stwierdzającego tożsamość, j) adres miejsca zamieszkania i adres do korespondencji, k) adres miejsca pobytu na terytorium Rzeczypospolitej Polskiej, jeżeli dana osoba nie ma na terytorium Rzeczypospolitej Polskiej miejsca zamieszkania, l) adres poczty elektronicznej, m) numer i rodzaj dokumentu potwierdzającego prawo do świadczeń opieki zdrowotnej finansowanych ze środków publicznych, n) stopień niepełnosprawności, o) rodzaj uprawnień oraz numer i termin ważności dokumentów potwierdzających uprawnienia do świadczeń opieki zdrowotnej określonego rodzaju oraz datę utraty tych uprawnień, p) numery identyfikacyjne i numery ewidencyjne nadawane usługobiorcom przez płatników lub usługodawców, r) datę zgonu, s) dane dotyczące zaświadczenia lekarskiego, o których mowa w art. 55 ust. 3 ustawy z dnia 25 czerwca 1999 roku o świadczeniach pieniężnych z ubezpieczenia społecznego w razie choroby i macierzyństwa (DzU z 2017 r. poz. 1368), t) przyczynę zgonu, u) informację o prawie do świadczeń opieki zdrowotnej finansowanych ze środków publicznych, v) numer identyfikacyjny płatnika, w) numer telefonu kontaktowego, $\mathrm{x}$ ) informację o sprzeciwie zawartym w centralnym rejestrze sprzeciwów na pobranie komórek, tkanek i narządów ze zwłok ludzkich, o którym mowa w art. 7 ust. 1 ustawy z dnia 1 lipca 2005 roku o pobieraniu, przechowywaniu i przeszczepianiu komórek, tkanek i narządów" (DzU z 2017 r. poz. 1000).

Za jednostkowe dane medyczne uważa się „dane osobowe oraz inne dane osób fizycznych dotyczące uprawnień do udzielonych, udzielanych i planowanych świadczeń opieki zdrowotnej, stanu zdrowia, a także inne dane przetwarzane w związku z planowanymi, udzielanymi i udzielonymi świadczeniami opieki zdrowotnej oraz profilaktyką zdrowotną i realizacją programów zdrowotnych". Interpretacja przepisów prowadzi do wniosku, że jednostkowe dane medyczne dzielą się na dane osobowe oraz dane inne niż osobowe. Jednakże przepisy te stoją w sprzeczności z ustawą o ochronie danych osobowych, ponieważ dane dotyczące osób fizycznych również stanowią dane osobowe. Jak wskazuje Mariusz Jagielski jedyne wyjście z sytuacji to zatem uznanie, że pojęcie „dane osobowe” na gruncie tej ustawy ma inne znaczenie niż na gruncie ustawy o ochronie danych osobowych (Jagielski, 2016, s. 6) i ogranicza się do danych identyfikujących pacjenta, a jednostkowe dane medyczne to zaś to samo, co dane osobowe w rozumieniu ustawy o ochronie danych osobowych. 
Prowadzi to do wniosku, że jednostkowe dane medyczne to wszystkie dane pacjenta - zarówno dane identyfikujące, jak i dane o osobie już identyfikowanej. Możliwe jest również, że taki podział ma na celu odróżnienie danych o stanie zdrowia od pozostałych danych osobowych. Należy podzielić w tym zakresie pogląd M. Jagielskiego, który wskazuje, że żadna z tych interpretacji nie jest konsekwentna w kontekście katalogu danych osobowych $\mathrm{z}$ art. 4 ust. 3 pkt 1, ponieważ np. dane o stopniu niepełnosprawności czy dane dotyczące zaświadczenia lekarskiego na temat zdrowia - są to informacje o osobie już zidentyfikowanej (Jagielski, 2016, s. 6).

Pomimo wielokrotnego posługiwania się, zarówno w ustawie o prawach pacjenta, jak i w ustawie o Rzeczniku Praw Pacjenta, a także w ustawie o systemie informacji w ochronie zdrowia, pojęciem „stanu zdrowia” czy „ochrony zdrowia", żaden z tych aktów prawnych nie odpowiadał na pytanie, czym jest zdrowie i czym są dane dotyczące zdrowia.

Wydaje się więc, że odpowiedzi na te pytania należy szukać poza krajowym porządkiem. Próbę zdefiniowania czym jest zdrowie podjęła już w 1946 roku Światowa Organizacja Zdrowia, określając zdrowie jako „stan pełnego fizycznego, umysłowego i społecznego dobrostanu, a nie tylko całkowity brak choroby czy niepełnosprawności” 18 .

Natomiast określenia, co rozumiem poprzez pojęcie „dane dotyczące zdrowia”, dokonano w ramach rekomendacji R(97)5 wskazując, że są to „wszelkie dane osobowe dotyczących stanu zdrowia danej osoby". Ponadto, pojęcie to odnosi się również do danych „mających oczywisty i ścisły związek ze zdrowiem oraz z danymi genetycznymi". Definicja podana w rekomendacji nie wskazuje wprost, że do takich danych należy zaliczyć także informacje dotyczące nałogów, aczkolwiek stwierdzenie, że do danych dotyczących zdrowia zaliczają się „dane mające oczywisty i ścisły związek ze zdrowiem”, wydaje się nie stać w sprzeczności z zaliczeniem do nich także informacje o nałogach, które mają mieć przecież wpływ na stan zdrowia danej osoby. W doktrynie wskazuje się, że „pojęcie nałogu łączy się w praktyce $\mathrm{z}$ uzależnieniem [...] w pewnych wypadkach (choć nie zawsze) informacje o liczbie palonych papierosów lub też częstotliwości palenia mogą być uznane za dane wskazujące na nałóg”. Podobnie byłoby np. w przypadku informacji o rodzaju preferowanego alkoholu z jednej strony, która to informacja nie wskazuje na nałóg, a o częstotliwości jego spo-

18 Tłumaczenie własne. Tekst oryginalny: „Health is a state of complete physical, mental and social well-being and not merely the absence of disease or infirmity". Cytat pochodzi z Preambuły do Konstytucji Światowej Organizacji Zdrowia, Porozumienie zawarte przez Rządy reprezentowane na Międzynarodowej Konferencji Zdrowia i Protokół dotyczący Międzynarodowego Urzędu Higieny Publicznej, podpisane w Nowym Jorku dnia 22 lipca 1946 roku. 
żywania, która to informacja już nie może być w sposób tak oczywisty skategoryzowana (Barta, Lityński, 2015, s. 309).

\section{Dane dotyczące zdrowia w rozporządzeniu 2016/679 - analiza motywów i artykułów}

Rozporządzenie 2016/679, podtrzymując w tym zakresie terminologię z dyrektywy 95/46/WE, pozostaje przy pojęciu „dane dotyczące zdrowia”. RODO wprowadza ponadto definicję legalną danych dotyczących zdrowia wskazując, że są to „dane osobowe o zdrowiu fizycznym lub psychicznym osoby fizycznej - w tym o korzystaniu z usług opieki zdrowotnej - ujawniające informacje o stanie jej zdrowia". Takie ujęcie danych dotyczących zdrowia rozumianych jako dane o zdrowiu fizycznym lub psychicznym jest zgodne $\mathrm{z}$ definicja zdrowia zaproponowaną przez Światową Organizację Zdrowia, w myśl której zdrowie to dobrostan fizyczny i psychiczny organizmu ${ }^{19}$.

Tak samo jak w dyrektywie 95/46/WE, w ogólnym rozporządzeniu o ochronie danych osobowych dane dotyczące zdrowia są zaliczane do szczególnych kategorii danych osobowych, których przetwarzanie jest co do zasady zakazane, jednakże istnieje wiele wyjątków od tego zakazu, ujętych w zamkniętym katalogu w art. 9 ust. 2. Nie ma wątpliwości, iż specyfika tych danych jako odnoszących się do sfery prywatności czy nawet intymności człowieka sprawia, iż konieczne jest zastosowanie szczególnych standardów ochrony w procesach przetwarzania tych informacji (Bielak-Jomaa, Lubasz, 2018, s. 278).

Jak wskazuje motyw 35 rozporządzenia „do danych osobowych dotyczących zdrowia należy zaliczyć wszystkie dane o stanie zdrowia osoby, której dane dotyczą, ujawniające informacje o przeszłym, obecnym lub przyszłym stanie fizycznego lub psychicznego zdrowia osoby, której dane dotyczą. Do danych takich należą informacje o danej osobie fizycznej zbierane podczas jej rejestracji do usług opieki zdrowotnej lub podczas świadczenia jej usług opieki zdrowotnej zgodnie z dyrektywą 2011/24/UE"20. Chodzi więc o informacje o obecnym, przesztym lub prognozowanym stanie zdrowia. Są to więc zarówno dane podawane przez pacjenta podczas rejestracji np. w przychodni, ale także uzyskiwane podczas wywiadu lekarskiego czy uzyskane w wyniku dokonywanych badań. O ile nie budzi wątpliwości kwestia przeszłego czy też obecnego stanu zdrowia, o tyle rozważyć wypada, jakie dane mogą wskazywać na przy-

19 http://www.who.int/suggestions/faq/en/ (dostęp: 30.11.2017).

20 Dyrektywa Parlamentu Europejskiego i Rady 2011/24/UE z dnia 9 marca 2011 roku w sprawie stosowania praw pacjentów w transgranicznej opiece zdrowotnej. 
szły stan zdrowia. Można przypuszczać, że mogą to być w szczególności informacje na temat nieuleczalnych lub długotrwałych chorób i związanego z nimi leczenia, rokowań wynikających z obecnego stanu zdrowia, planowanych badań medycznych, zabiegów, operacji, wizyt lekarskich czy nawet terapii.

Ponadto, w motywie tym jest wymieniany katalog informacji, które zaliczają się do tej kategorii danych osobowych - numer, symbol lub oznaczenie przypisane danej osobie fizycznej w celu jednoznacznego zidentyfikowania tej osoby fizycznej do celów zdrowotnych; informacje pochodzące z badań laboratoryjnych lub lekarskich części ciała lub płynów ustrojowych, w tym danych genetycznych i próbek biologicznych; oraz wszelkie informacje, np. o: chorobie, niepełnosprawności, ryzyku choroby, historii medycznej, leczeniu klinicznym, stanie fizjologicznym lub biomedycznym osoby, której dane dotyczą, niezależnie od ich źródła, którym może być np. lekarz lub inny pracownik służby zdrowia, szpital, urządzenie medyczne lub badanie diagnostyczne in vitro. Katalog ten nie jest zamknięty - zawiera tylko przykładowe wyliczenie.

Także motyw 53 odnosi się pośrednio do danych dotyczących zdrowia poprzez wskazanie, że „szczególne kategorie danych osobowych zasługujące na większą ochronę powinny być przetwarzane do celów zdrowotnych wyłącznie w przypadkach, gdy jest to niezbędne do realizacji tych celów z korzyścią dla osób fizycznych i ogółu społeczeństwa”. Uwagę zwraca pojęcie „cele zdrowotne". Porównując polskie tłumaczenie z angielskim widać rozbieżności, ponieważ w angielskiej wersji językowej rozporządzenia nie występuje sformułowanie „for health purposes”, ale „for health-related purposes”. Polskie tłumaczenie, nie do końca oddaje więc sens tego stwierdzenia, bo należałoby je raczej tłumaczyć jako „cele powiązane ze zdrowiem”. Ponadto, zgodnie ze Stownikiem Języka Polskiego PWN, słowo „zdrowotny” może oznaczać nie tylko „dotyczący stanu zdrowia”, ale również „korzystnie wpływający na zdrowie". Należałoby więc uznać, że w tym przypadku chodzi raczej o to pierwsze znaczenie, ponieważ drugie zawęża rozumienie tego pojęcia i może wprowadzać w błąd co do zakresu znaczeniowego „celów zdrowotnych” jako takich celów, które służą tylko do polepszenia stanu zdrowia. Motyw 53 zawiera także katalog sytuacji, w których dochodzi do przetwarzania szczególnych kategorii danych osobowych (w tym danych dotyczących zdrowia) w celach zdrowotnych:

- zarządzanie usługami i systemami opieki zdrowotnej i zabezpieczenia społecznego, w tym przetwarzanie takich danych przez organy zarządcze i centralne krajowe organy ds. zdrowia do celów kontroli jakości;

- pozyskiwanie informacji zarządczych oraz ogólnego krajowego i lokalnego nadzoru nad systemem opieki zdrowotnej i zabezpieczenia społecznego; 
- zapewnianie ciągłości opieki zdrowotnej lub zabezpieczenia społecznego oraz transgranicznej opieki zdrowotnej;

- do celów bezpieczeństwa, monitorowania i ostrzegania zdrowotnego;

- do celów archiwalnych w interesie publicznym;

- do celów badań naukowych lub historycznych;

- do celów statystycznych, które mają podstawę w prawie Unii Europejskiej lub w prawie państwa członkowskiego i służą interesowi publicznemu;

- na potrzeby analiz prowadzonych $\mathrm{w}$ interesie publicznym $\mathrm{w}$ dziedzinie zdrowia publicznego.

Rozporządzenie wprowadza także szereg uregulowań odnoszących się do przetwarzania danych wrażliwych, np. wskazuje, że takie dane zgodnie z art. 22 ust. 4 nie mogą być przedmiotem decyzji podejmowanych w sposób zautomatyzowany, chyba że osoba wyraziła wyraźną zgodę lub przetwarzanie jest niezbędne ze względów związanych $\mathrm{z}$ ważnym interesem publicznym $\mathrm{i}$ istnieją właściwe środki ochrony praw, wolności i prawnie uzasadnionych interesów osoby, której dane dotyczą. Ponadto, art. 35 ust. 2 wskazuje, że obligatoryjnie należy przeprowadzić ocenę skutków dla ochrony danych danego rodzaju przetwarzania, w przypadku gdy wiąże się ono z przetwarzaniem na dużą skalę szczególnych kategorii danych osobowych, a w artykule 37 ust. 1 pkt c nakłada obowiązek wyznaczenia inspektora ochrony danych, gdy główna działalność administratora lub podmiotu przetwarzającego polega na przetwarzaniu na dużą skalę szczególnych kategorii danych osobowych.

\section{Wyraźna a nie pisemna zgoda na przetwarzanie danych wrażliwych}

Przetwarzanie szczególnych kategorii danych osobowych jest dopuszczalne wyłącznie w okolicznościach określonych w art. 9 ust 2 RODO. W porównaniu z regulacją zawartą w dyrektywie 95/46/WE katalog tych przesłanek jest w zasadzie zbliżony, aczkolwiek w rozporządzeniu 2016/679 wprowadzono dwa nowe wyjątki od zakazu przetwarzania danych wrażliwych: interes publiczny w dziedzinie zdrowia publicznego oraz realizację celów archiwalnych w interesie publicznym, celów badań naukowych lub historycznych lub celów statystycznych. Niektóre z pozostałych przesłanek zostały natomiast nieco inaczej ujęte (zob. m.in. Jarguz, 2017, s. 95).

Podstawową przesłanką uchylającą zakaz przetwarzania danych sensytywnych jest zgoda osoby, której dane dotyczą. Głównym elementem odróżniającym jednak oświadczenie o wyrażeniu zgody na przetwarzanie danych z art. 27 
ust. 2 pkt 1 od oświadczenia $\mathrm{z}$ art. 23 ust. 1 pkt 1 ustawy o ochronie danych osobowych jest wymóg złożenia takiego oświadczenia na piśmie. Wartym podkreślenia jest, że dyrektywa 95/46/WE nie zawierała wymogu pisemnej zgody - polski ustawodawca zdecydował się jednak dodać ten wymóg implementując dyrektywę. W literaturze (Barta, Fajgielski, Markiewicz, 2015, s. 490-491; Drozd, 2008, s. 171) panował pogląd, że zgoda na przetwarzanie wrażliwych danych osobowych udzielona w formie innej niż pisemna jest nieskuteczna, a przepisy Komisji o formie czynności prawnych nie znajdują w tym zakresie zastosowania. Dochowanie więc formy pisemnej było warunkiem skuteczności takiego oświadczenia (Barta, Litwiński, 2015, s. 210).

Takie sformułowanie zgody stanowi istotne novum, ponieważ określenia wymaga, kiedy zgodę można uznać za wyraźną. Już w trakcie prac nad dyrektywą 95/46/WE rozważano, czy do zgody dotyczącej przetwarzania danych wrażliwych należy dodać wymóg pisemności jako dodatkowy w stosunku do tego, że zgoda powinna być wyraźna ${ }^{21}$. Ostatecznie jednak w dyrektywie odstąpiono od wyrażania zgody w formie pisemnej. W uzasadnieniu Rady22 nie podano konkretnych wyjaśnień wprowadzonych zmian. Na stronie 4 stwierdzono jednak: „wprowadzono [...] pewne zmiany w celu [...] uzyskania pewnej elastyczności, która gwarantuje równoważną ochronę [...], ale nie skutkuje obniżeniem poziomu ochrony; umożliwiają one efektywne i pozbawione biurokratycznych obciążeń stosowanie ogólnych zasad, uwzględniając znaczną różnorodność sposobów [...] przetwarzania danych"23.

Jak wskazano w Opinii Grupy Roboczej dotyczącej zgody z 2011 roku „zgoda wyraźna ma miejsce we wszystkich sytuacjach, gdy osobie fizycznej przedstawia się propozycję wyrażenia przyzwolenia (lub nie) na konkretny sposób wykorzystania lub ujawnienia jej danych osobowych, a osoba ta aktywnie (ustnie lub pisemnie) odpowiada na zadane pytanie"24.

21 W art. 17 wniosku Komisji dotyczącym dyrektywy w sprawie ochrony osób fizycznych w zakresie przetwarzania danych osobowych, COM(90)314 wersja ostateczna, SYN 287 i 288, Bruksela, 13 września 1990 roku dotyczącym danych szczególnie chronionych znalazł się wymóg, aby zgoda była „wyraźna i pisemna”. Natomiast w zmienionym wniosku Komisji dotyczący dyrektywy Rady w sprawie ochrony osób fizycznych w zakresie przetwarzania danych osobowych i swobodnego przepływu tych danych, COM(92)422 wersja ostateczna - SYN 287, Bruksela, 15 października 1992 roku w przypadku danych szczególnie chronionych zachowano wymóg zgody „pisemnej”.

22 Wspólne stanowisko Rady w sprawie wniosku dotyczącego dyrektywy Parlamentu i Rady w sprawie ochrony osób fizycznych w zakresie przetwarzania danych osobowych i swobodnego przepływu tych danych, (00/287) COD, przyjęte 15 marca 1995 roku, s. 4.

23 Opinia 15/2011 w sprawie definicji zgody, http://ec.europa.eu/justice/data-protection/article-29/ documentation/opinion-recommendation/files/2011/wp187_pl.pdf, s. 5 i 6 (dostęp: 29.11.2017).

24 Ibidem, s. 27. 
Jak wskazano w odniesieniu do usług on-line, zaznaczenie check-boxa „na formularzu po otrzymaniu odpowiednich informacji stanowi wyraźną, jednoznaczną zgodę, gdyż działanie polegające na zaznaczeniu pola wyboru jest wystarczająco jasne, by nie pozostawiać wątpliwości co do woli uczestnictwa osoby fizycznej w programie lojalnościowym". Takie rozumienie wyraźnej zgody znacząco zmienia sytuację $\mathrm{w}$ odniesieniu do przetwarzania danych osobowych wrażliwych, w tym danych dotyczących zdrowia w środowisku internetowym, dając szansę m.in. na efektywny rozwój usług medycznych świadczonych w formie telemedycyny.

Jeśli szczególne kategorie danych osobowych, w tym dane dotyczące zdrowia, są przetwarzane na podstawie zgody, powinna ona być nie tylko wyraźna, ale przede wszystkim spełniać wszystkie wymogi, o których mowa w definicji zgody z art. 4 pkt 11 i art. 7, który wskazuje na warunki jej wyrażenia, tj.:

- powinna być wyrażona przez osobę, której dane dotyczą;

- stanowi dobrowolne, konkretne, świadome i jednoznaczne okazanie woli, którym może być oświadczenie woli lub wyraźne działanie potwierdzające;

- powinna zawierać przyzwolenie na przetwarzanie danych osobowych ${ }^{25}$;

- nie może być od niej uzależnione wykonanie umowy, w tym świadczenie usługi, jeśli przetwarzanie danych osobowych nie jest niezbędne do wykonania tej umowy;

- oświadczenie o zgodzie powinno zawierać informację, że osoba ma prawo w dowolnym momencie wycofać zgodę co nie wpływa na zgodność z prawem przetwarzania, którego dokonano na jej podstawie przed wycofaniem;

- oświadczenie o zgodzie powinno być przedstawione w sposób pozwalający wyraźnie odróżnić je od pozostałych kwestii, w zrozumiałej i łatwo dostępnej formie, jasnym i prostym językiem;

- administrator powinien móc wykazać, że zgoda została wyrażona - wyrażenie zgody powinno zostać utrwalone np. w formie nagrania, e-maila, na piśmie itp.

Rozporządzenie w art. 8 odnosi się także do zgody wyrażonej przez dziecko, w przypadku usług społeczeństwa informacyjnego oferowanych bezpośrednio dziecku wskazując, że „Jeżeli zastosowanie ma art. 6 ust. 1 lit. a, w przypadku usług społeczeństwa informacyjnego oferowanych bezpośrednio dziecku, zgodne $\mathrm{z}$ prawem jest przetwarzanie danych osobowych dziecka, które ukończyło 16 lat. Jeżeli dziecko nie ukończyło 16 lat, takie przetwarzanie jest zgodne

25 Wydaje się więc, że samo „Wyrażam zgodę” nie spełnia tego warunku. Tak samo „Wyrażam zgodę na nieprzetwarzanie moich danych osobowych" również go nie spełnia, gdyż nie stanowi działania potwierdzającego, lecz działanie zaprzeczające. 
z prawem wyłącznie w przypadkach, gdy zgodę wyraziła lub zaaprobowała ją osoba sprawująca władzę rodzicielską lub opiekę nad dzieckiem oraz wyłącznie w zakresie wyrażonej zgody". Przepis ten budzi wiele wątpliwości interpretacyjnych (Bielak-Jomaa, Lubasz, 2018, s. 427-436), w dużym stopniu spowodowanych brakiem m.in. określenia mechanizmu wyrażania lub aprobowania zgody dziecka, regulacji sposobów weryfikacji tożsamości udzielających zgodę, uregulowania granicy wieku, poniżej której dziecko zgody w ogóle wyrazić nie może26.

Z perspektywy niniejszych rozważań istotne jest jednak, czy dziecko, które ukończyło 16 rok życia ${ }^{27}$ może wyrazić zgodę na przetwarzanie danych dotyczących zdrowia, w przypadku korzystania z usług społeczeństwa informacyjnego oferowanych bezpośrednio dziecku. Na tak postawione pytanie należy udzielić odpowiedzi negatywnej, ponieważ art. 8 wskazuje, że podstawą zgody dziecka nie jest zgoda $\mathrm{z}$ art. 9 ust. 2 pkt b, a zgoda z art. 6 ust 1 pkt a, która nie stanowi przesłanki legalizującej przetwarzanie szczególnych kategorii danych.

\section{Podsumowanie}

Ogólne rozporządzenie o ochronie danych osobowych jest stosowane od 25 maja 2018 roku. Celem regulacji było przede wszystkim zapewnienie wysokiego i spójnego stopnia ochrony osób fizycznych oraz usunięcie przeszkód w przepływie danych osobowych w Unii Europejskiej. Należało więc zapewnić równorzędny we wszystkich państwach członkowskich stopień ochrony praw i wolności osób fizycznych w związku z przetwarzaniem takich danych.

Rozporządzenie tak samo jak dyrektywa wyróżniało szczególne kategorie danych osobowych i pozostałe dane, nazywane danymi zwykłymi. Jak wskazuje motyw 51 szczególne kategorie danych „z racji swego charakteru są szczególnie wrażliwe w świetle podstawowych praw i wolności i dlatego wymagają szczególnej ochrony, gdyż kontekst ich przetwarzania może powodować poważne ryzyko dla podstawowych praw i wolności". Do takich danych zalicza się dane dotyczące zdrowia, których definicja została ujęta w art. 4 pkt 15 rozporządzenia. Rozporządzenie posługuje się nazwą funkcjonującą już w dyrektywie 95/46/WE, podczas gdy do tej pory w polskiej ustawie, funkcjonowało pojęcie

26 Por. Uzasadnienie do projektu ustawy o ochronie danych osobowych, s. 7-11, https://legislacja. rcl.gov.pl/docs//2/12302950/12457664/12457665/dokument308360.pdf (dostęp: 26.11.2017).

27 W Uzasadnieniu do projektu ustawy o ochronie danych osobowych projektodawca proponuje obniżenie granicy wieku do 13. roku życia, wykorzystując kompetencję przyznaną państwom członkowskim w myśl art. 8 ust. 1, s. 7-11, https://legislacja.rcl.gov.pl/docs//2/12302950/1245 7664/12457665/dokument308360.pdf (dostęp: 26.11.2017). 
dane o stanie zdrowia i nie było jasne czy zakres znaczeniowy tych pojęć jest tożsamy.

Ponadto, rozporządzenie wprowadza nowe wymogi dotyczące zgody, zastępując zgodę pisemną zgodą wyraźną - co w dużej mierze racjonalizuje podejście dotyczące zgody, gdyż współczesne metody uwierzytelniania, np. profil zaufany $^{28}$ czy podpis elektroniczny ${ }^{29}$, zapewniają gwarancje bezpieczeństwa danych i uwierzytelniają osobę, której dane dotyczą przynajmniej w stopniu, który do tej pory gwarantował własnoręcznie złożony podpis tej osoby.

Rozporządzenie wprowadza także zmiany w zakresie zgody dziecka, jednak w wielu kwestiach pozostawia wiele pytań o sposoby wdrożenia jego postanowień, które mogą prowadzić nie tylko do zróżnicowania podejścia, lecz także do zróżnicowania stopnia ochrony między krajami członkowskim, podczas gdy jednym z celów było ujednolicenie ochrony w ramach krajów członkowskich. Niewątpliwie jednak w zakresie usług społeczeństwa informacyjnego oferowanych bezpośrednio, które miałyby obejmować dane wrażliwe, nie ma możliwości skutecznego wyrażenia zgody przez dziecko, które ukończyło 16 lat, gdyż sytuacja ta obejmuje wyłącznie zgodę na przetwarzanie danych zwykłych $\mathrm{z}$ art. 6 ust. 1 pkt a.

Niewątpliwie regulacje obligujące do zwiększenia ochrony m.in. przez obowiązek powołania inspektora ochrony danych, dokonania oceny skutków dla ochrony danych osobowych czy elastyczne regulacje poszczególnych przepisów RODO, np. w zakresie bezpieczeństwa przetwarzania wskazują, że ustawodawca unijny widział potrzebę uwzględnienia stopnia ochrony danych także w zależności od kategorii przetwarzanych danych osobowych.

Administratorzy przetwarzający dane dotyczące zdrowia powinni mieć podwyższone środki do ich ochrony, ponieważ przetwarzanie szczególnych kategorii danych, nawet $\mathrm{z}$ uwzględnieniem złagodzonych warunków dotyczących zgody, jest nadal możliwe tylko w ściśle określonych sytuacjach, a z uwagi na podejście oparte na ryzyku, to na administratorze będzie spoczywał obowiązek zabezpieczenia tych danych w sposób adekwatny do poziomu ryzyka ich naruszenia.

28 Ustawa z dnia 17 lutego 2005 roku o informatyzacji działalności podmiotów realizujących zadania publiczne. DzU z 2005 r., nr 64 poz. 565 z późn. zm.

29 Ustawa $z$ dnia 5 września 2016 roku o usługach zaufania oraz identyfikacji elektronicznej. DzU z 2016 r., poz. 1579. 


\section{Bibliografia}

Barta, J., Fajgielski, P. i Markiewicz R. (2015). Ochrona danych osobowych. Komentarz. Warszawa: Wydawnictwo Wolters Kluwer bussiness.

Barta, P., Litwiński, P. (2015). Ustawa o ochronie danych osobowych. Komentarz. Warszawa: Wydawnictwo C.H. Beck.

Bielak-Jomaa, E., Lubasz, D. (2018). RODO. Ogólne rozporzadzenie o ochronie danych osobowych. Komentarz. Warszawa: Wolters Kluwer Polska.

Drozd, A. (2008). Ustawa o ochronie danych osobowych. Komentarz. Wzory pism i przepisy. Warszawa: Wydawnictwo Prawnicze LexisNexis.

Dyrektywa 95/46/WE Parlamentu Europejskiego i Rady z dnia 24 października 1995 roku w sprawie ochrony osób fizycznych w zakresie przetwarzania danych osobowych oraz swobodnego przepływu tych danych. Dz.Urz. WE, z 23 listopada 1995 r., L 281.

Dyrektywa Parlamentu Europejskiego i Rady 2011/24/UE z dnia 9 marca 2011 roku w sprawie stosowania praw pacjentów w transgranicznej opiece zdrowotnej. Dz.Urz. UE z 2011 r., L88/45.

http://www.who.int/suggestions/faq/en/ (dostęp: 30.11.2017).

Jagielski, M. (2016). Pojęcie danych medycznych i zasady ich ochrony. W: Ochrona danych osobowych medycznych. Warszawa: Wydawnictwo C.H. Beck.

Jarguz, J. (2017). Zewnętrzna obsługa: zewnętrzna obsługa kadrowo-płacowa, zewnętrzna obsługa w zakresie badań profilaktycznych, prywatna opieka zdrowotna pracowników. W: D. Dörre-Kolasa (red.). Ochrona danych osobowych pracowników w świetle rozporzadzenia Parlamentu Europejskiego i Rady. Warszawa: Wydawnictwo C.H. Beck.

Konwencja nr 108 Rady Europy o ochronie osób w związku z automatycznym przetwarzaniem danych osobowych, sporządzona w Strasburgu dnia 28 stycznia 1981 roku. DzU z 2003 r., nr 3, poz. 25.

Krasińska, M. (2016). Przetwarzanie danych osobowych w dokumentacji medycznej. W: Ochrona danych osobowych medycznych. Warszawa: Wydawnictwo C.H. Beck.

Kulesza, E. (2000). Ochrona danych o stanie zdrowia w świetle ustawodawstwa europejskiego i polskiej ustawy o ochronie danych osobowych. Prawo i Medycyna (5).

Ocena skutków regulacji - Projekt ustawy o ochronie danych osobowych, s. 3, https:// legislacja.rcl.gov.pl/docs//2/12302950/12457664/12457665/dokument308359.pdf (dostęp: 24.11.2017).

Opinia 15/2011 w sprawie definicji zgody, http://ec.europa.eu/justice/data-protection/article-29/ documentation/opinion-recommendation/files/2011/wp187_pl.pdf (dostęp: 29.11.2017).

Preambuła do Konstytucji Światowej Organizacji Zdrowia, Porozumienie zawarte przez Rządy reprezentowane na Międzynarodowej Konferencji Zdrowia i Protokół dotyczący Międzynarodowego Urzędu Higieny Publicznej, podpisane w Nowym Jorku dnia 22 lipca 1946 roku. DzU z 1948 r., nr 61 poz. 477.

Projekt ustawy - Przepisy wprowadzające ustawę o ochronie danych osobowych, https:// legislacja.rcl.gov.pl/docs//2/12302951/12457706/12457707/dokument308373.pdf (dostęp: 22.11.2017).

Projekt ustawy o ochronie danych osobowych, https://legislacja.rcl.gov.pl/docs//2/12302950/ 12457664/12457665/dokument308361.pdf (dostęp: 22.11.2017).

Recommendation No.R (97) 5 of the Committee of Ministers to Member States on the protection of medical data (Adopted by the Committee of Ministers on 13 February 1997 at the 584th meeting of the Ministers' Deputies), https://www.google.pl/url?sa=t 
$\& \mathrm{rct}=\mathrm{j} \& \mathrm{q}=\& \mathrm{esrc}=\mathrm{s} \&$ source $=$ web $\& \mathrm{~cd}=1 \& \mathrm{cad}=\mathrm{rja} \& \mathrm{uact}=8 \& \mathrm{ved}=0 \mathrm{ahUKEwjq} 5 \mathrm{oOO} 0$ eHXAhWJIOwKHRqnDaMQFggqMAA\&url=https $\% 3 \mathrm{~A} \% 2 \mathrm{~F} \% 2 \mathrm{Frm} . c 0 e$. int $\% 2 \mathrm{FCoER}$ MPublicCommonSearchServices\%2FDisplayDCTMContent\%3FdocumentId\%3D09000 016806af967\&usg=AOvVaw2acyV-MKt3tPhMKpE7yAMD (dostęp: 26.11.2017).

Rozporządzenie Parlamentu Europejskiego i Rady (UE) 2016/679 z dnia 27 kwietnia 2016 roku w sprawie ochrony osób fizycznych w związku z przetwarzaniem danych osobowych i w sprawie swobodnego przepływu takich danych oraz uchylenia dyrektywy 95/46/WE.

Sibiga, G. (2003). Postępowanie w sprawach ochrony danych osobowych. Warszawa: Dom Wydawniczy ABC.

Słownik języka polskiego PWN. https://sjp.pwn.pl/szukaj/zdrowotny.html (dostęp: 28.12.2017).

Ustawa z dnia 17 lutego 2005 r. o informatyzacji działalności podmiotów realizujących zadania publiczne. DzU z 2005 r., nr 64 poz. 565 z późn. zm.

Ustawa z dnia 28 kwietnia 2011 r. o systemie informacji w ochronie zdrowia. DzU z 2017 r., poz. 1845 t.j. z późn. zm.).

Ustawa z dnia 29 sierpnia 1997 roku o ochronie danych osobowych. DzU z 1997 r., nr 133 poz. 883 .

Ustawa z dnia 5 września 2016 r. o usługach zaufania oraz identyfikacji elektronicznej. DzU z 2016 r. poz. 1579).

Ustawa z dnia 6 listopada 2008 r. o prawach pacjenta i Rzeczniku Praw Pacjenta. DzU z 2017 r. poz. 1318 t.j. z późn. zm.

Uzasadnienie do projektu ustawy o ochronie danych osobowych, https://legislacja.rcl.gov.pl/ docs//2/12302950/12457664/12457665/dokument308360.pdf (dostęp: 26.11.2017).

Wąsik, D. (2015). Komentarz do art. 2 ustawy o systemie informacji w ochronie zdrowia. W: D. Wąsik. Ustawa o systemie informacji w ochronie zdrowia. Komentarz. Warszawa: Wydawnictwo Wolters Kluwer. 


\title{
Karolina Elżbieta Stangret ${ }^{1}$
}

\section{Historia turystyki medycznej. Krótki zarys od starożytności do XIX wieku}

\begin{abstract}
Streszczenie
Celem artykułu jest zarysowanie historii turystyki medycznej od czasów starożytnych aż po XIX wiek. Poprzez wieki zmieniała się ludzka wiedza na temat ciała, a wraz z nią wiedza medyczna. Jednak dostęp do lekarzy i środków uzdrawiających nie był powszechny ani osiągalny dla każdego, co często wiązało się z podróżowaniem w celu wyleczenia choroby lub poprawy stanu zdrowia. W artykule przedstawiono pokrótce, jak zmieniały się sposoby leczenia, co na to wpływało i jaki miało to związek z podróżowaniem w celach medycznych. Przez długie stulecie leczono głównie ziołami oraz wodą termalną i mineralną, co zmieniła dopiero nowoczesna medycyna. Prześledzono poprzez kolejne epoki historyczne, gdzie konkretnie udawano się leczyć i czym się w takich miejscach zajmowano. W artykule dokonano studium literatury.
\end{abstract}

Słowa kluczowe: historia, ochrona zdrowia, turystyka medyczna.

History of Medical Tourism. An Overview From Ancient Times to the 19th Century

\begin{abstract}
The aim of the article is to outline the history of medical tourism from ancient times until the 19th century. In the course of the centuries, human knowledge about the body, along with medical knowledge, has changed. However, access to doctors and remedies was not universal or reachable for everyone, which was often associated with travelling in order to cure the disease or improve health. I introduce briefly how treatments evolved, what influenced that and how this was connected with travelling for medical purposes. For long centuries, people were treated mainly with herbs, thermal and mineral water, which changed modern medicine. Consecutive historical eras are traced back to depict where specifically people went to heal and what they did in such places. The article presents a study of literature.
\end{abstract}

Keywords: history, health care, medical tourism.

1 Karolina Elżbieta Stangret - mgr, niezależny badacz przy Instytucie Historii PAN, Rynek Starego Miasta 29/31, 00-272 Warszawa, e-mail: cinkarolina@gmail.com. 


\section{Wprowadzenie}

Zanim zostanie omówiona historia turystyki medycznej, przybliżony będzie termin „turystyka”. Powstał on w 1816 roku, jako synonim podróżnika, ale dopiero Stendhal upowszechnił je w 1838 roku w swoich „Pamiętnikach turysty”, gdzie mówi o turyście, że: „podróżuje z ciekawości i braku zajęcia” (Martin-Fugier, 2006). To jednak nie zmienia faktu, że ludzie podróżowali od starożytności w poszukiwaniu rozwiązania na ich dolegliwości lub aby żadna przypadłość ich nie dotknęła. Niniejsze opracowanie to krótki przegląd na temat podejścia do ludzkiego ciała i zdrowia w różnych okresach historycznych. Ma ono na celu zaznaczenie, jak owa turystka medyczna niegdyś wyglądała, jaki wpływ na podróżowanie związane z chorobą lub chęcią jej zapobieżenia miało podejście do ciała i choroby, a także jakie były najpopularniejsze zabiegi oraz miejsca, do których się udawano w Europie.

\section{Starożytność}

Podstawą w leczeniu czy zapobieganiu choroby była i zapewne nadal jest - woda. Wokół wody od zawsze był budowany świat symboliki, wzbogacający jej znaczenie jako substancji uzdrawiającej, której użycie miało charakter magiczny, religijny oraz medyczny. Takie funkcje wody widoczne były już w starożytnym Egipcie. Praktyczno-symboliczne użycie wody poświadczone zostało w jednej z lepiej zachowanych świątyń egipskich okresu ptolemejskiego i rzymskiego w Dendera, na północ od Teb. Wspaniały kompleks świątynny dedykowany bogini Hator obejmował główną świątynię, szereg kaplic, święte jezioro oraz inne budowle, których geneza sięgała czasów faraońskich. W jednym z budynków mieściło się tzw. sanatorium, czyli kompleks basenów, zasilany wodą systemem wodociągowym z pobliskiego świętego jeziora. W odróżnieniu od innych obiektów, woda tutaj służyła nie tyle do picia, ile do obmywania ciała i leczącej kąpieli. Wodą były też polewane specjalne stele kamienne z wizerunkiem Horusa, z wyrytymi formułami magicznymi. Nabierała ona dzięki temu „mocy sprawczej”, służyła do obmycia ciała chorego czy też do pocierania zbolałego lub zainfekowanego miejsca. Ponadto, popularny był w czasach grecko-rzymskich zwyczaj inkubacji w świątyniach egipskich, polegający na spędzeniu nocy w specjalnym pomieszczeniu, a następnie na interpretacji snu (głównie w świątyniach Serapisa, Izydy i Imhotepa). Stosowano również zabiegi ziołolecznictwa - w jedzeniu, napojach oraz w formie maści i olejków. Nie bez znaczenia termin „świątynia” to w dosłownym tłumaczeniu z języka egipskiego „dom życia”. Obok funkcji gospodarczych czy edukacyjnych świą- 
tynie były miejscami, w których leczono ciało, choroby oraz dbano o higienę. Szczególnie, że troska o ciało była silnie powiązana z pragnieniem życia wiecznego. Nie dziwi zatem fakt silnego zespolenia praktyk religijnych z medycznymi oraz funkcjonowanie w obrębie zespołów świątynnych służb medycznych (First, 2013).

Prócz Dendery sanatoria działały również przy świątyniach w Karnaku, będącym wtedy częścią Teb, świątyni Hatszepsut w Deir el-Bahari, w Serapeum, Kanopos, Tell Atrib (w Delcie), Abydos (w Górnym Egipcie) i na wyspie Elefantyna, na południowym skraju Górnego Egiptu. Ślady sanatorium odkryto także w słynnym późniejszym koptyjskim „Białym Klasztorze” w Deir el-Abiad, kilka kilometrów od miasta Sohag w środkowym Egipcie, znanym w czasach chrześcijańskich jako ośrodek monastyczny. Można założyć, iż tego typu instytucje były dostępne w promieniu kilkudniowej pielgrzymki i popularne wśród wiernych. Towarzyszyły im wyrocznie, zapewne targowiska, a także herbaria z ziołami i lekarstwami naturalnymi (First, 2013).

Przyjeżdżano do egipskich świątyń z odległych stron, co potwierdzają leczące stele Horusowe, znajdowane na terenie Syrii, Palestyny, Fenicji oraz na Cyprze, a także w Rzymie. Ówczesny świat chłonął wszelkie użyteczne narzędzia magiczne i medyczne, zapotrzebowanie to było wynikiem rosnącego wśród ludzi pragnienia dostępu do magii i medycyny (First, 2013). Pozwalały one bowiem na dłuższe życie i zachowanie w dobrym stanie ciała, które miało trafić w zaświaty.

Również starożytni Grecy nie stronili od wody. Myli się po to, aby poczuć się lepiej i zwiększyć swoją atrakcyjność. Natomiast kąpali się z przyczyn zdrowotnych, ponieważ moczenie się w wodzie stanowiło jeden $\mathrm{z}$ podstawowych zabiegów leczniczych w ograniczonym arsenale ówczesnych lekarzy. Lekarze znajdowali się głównie w świątyni Asklepiosa (pojawiają się w VI wieku p.n.e.), w miejscu przeznaczonym nie tylko do udzielania pomocy medycznej, ale również kształcenia adeptów sztuki lekarskiej. To z Egiptu do Grecji przyszła wiedza medyczna, gdzie trafiła do świątyń, gdyż bogowie i medycyna nadal stanowili nierozerwalną całość. Kapłanom w pracy towarzyszyły oswojone święte węże, trzymane w okolicach świętego źródła. Tresowano je w taki sposób, żeby wślizgiwały się na posłania rannych i wylizywały im chore miejsca. Podobne czynności wykonywały psy. Leczono również poprzez stosowanie diet, sporządzanie naparów z ziół, wykonywanie masaży oraz poprzez sen (ten sposób zapożyczono od Egipcjan).

W 460 roku p.n.e. na wyspie Kos, przy jednej ze świątyń przyszedł na świat Hipokrates, zwany ojcem medycyny. Pochodził on z rodziny Asklepiadów, która służyła w świątyni Asklepiosa (Marek, 2013). Hipokrates był zagorzałym 
orędownikiem kąpieli, wierząc, że roztropna kombinacja zimnych i gorących ablucji zapewnia utrzymanie zdrowych proporcji - humorów, to jest soków składowych ciała. Ciepłe kąpieli miały zmiękczać skórę, przygotowując ją do przyjęcia składników odżywczych oraz przynosić ulgę w całej gamie dolegliwości, począwszy od migreny po zatrzymanie moczu. Osobom cierpiącym na bolesność stawów zalecano zimne bicze, zaś choroby kobiece leczono aromatycznymi kąpielami parowymi (Ashenburg, 2017). Przy chorobach, którym towarzyszył skurcz mięśni (gdy zdarzały się latem u osobników młodych) zalecano omywanie ciała dużymi ilościami zimnej wody, ponieważ zabieg taki pobudzał i wzmagał ciepło ukryte w ciele (Bednarczyk, 1995). Hipokrates tak mówił o kąpielach: „Zażywający kąpieli winien zachować spokój i daleko posuniętą powściągliwość, nie powinien nic robić, inni mają oblewać go wodą i szorować" (Ashenburg, 2017, s. 22).

Ponadto, Hipokrates starał się zwalczać magiczne zabiegi lecznicze, do których przede wszystkim zaliczał hipnotyczny sen w świątyni, z którego wnioskowano, co dolega choremu i jak należy go leczyć. Dodatkowymi czynnikami wpływającymi na korzystne rezultaty leczenia były: podniosła atmosfera religijna, bliska obecność duchów uzdrawiających oraz uczucie fizycznego i psychicznego odprężenia, związane z łagodną muzyką i śpiewami mantrycznymi. Od czasów pradawnych podstawową gwarancją owocnego leczenia była, jest i będzie, wiara pacjentów w moc i umiejętności lekarzy.

Ponieważ medycy leczyli pod znakiem boga Asklepiosa, więc Grecy udawali się w podróże medyczne do jego najbliższej świątynie. Przede wszystkim na wyspę Kos, Epidauros i do Pergamonu, a także do Aten, Koryntu i Smyrny.

Grecy na co dzień udawali się do łaźni, nie tylko w celach higienicznych, ale także zdrowotnych, gdyż uważali, że dbanie o ciało zapobiega chorobom. Łaźnie często były połączone z gimnazjonami. W jednym miejscu zażywano wysiłku fizycznego, kąpieli i sauny, na koniec w ciało wcierano wonne olejki.

Starożytni Rzymianie nabyli swoją wiedzę medyczną od Greków. Zanim sprowadzili do Rzymu lekarzy, opiekę medyczną nad mieszkańcami Rzymu sprawował zamieszkały od 291 roku p.n.e. w asklepiejonie na wyspie na rzece Tybrze, bóg Asklepios (znany w Rzymie pod imieniem Aesculapius). Ale zanim chorzy Rzymianie udawali się o pomoc do Asklepiosa, pierwsze zabiegi lecznicze przeprowadzano w ich własnych domach przez pater familias. Jego wiedza i umiejętności lekarskie stanowiły mieszaninę rozwijającej się od wieków medycyny ludowej i magii.

Na przełomie II-I wieku p.n.e. w Rzymie osiedlił się pochodzący z Prusy Asklepiades (zmarł w 91 roku n.e.), lekarz ten rozpowszechniał wiedzę Hipokratesa (Bednarczyk, 1995). Asklepiades praktykował w Bitynii, w słynnej 
przez wieki ze swoich term Prusie Olimpowej. Po drodze do Rzymu zatrzymał się w Smyrnie, także bogatej w ciepłe źródła, gdzie rozwijał praktykę hydroterapeutyczną. Jego mottem było: „Tuto, celeriter, iucunde” ([leczyć] pewnie, szybko, przyjemnie) (Ashenburg, 2017, s. 30). Metody Asklepiadesa, szczególnie dotyczące wodolecznictwa zimnego i ciepłego, stosowała później szkoła metodyków, która powstała w I wieku p.n.e. Przedstawicielem jej był Soren z Efezu, który leczył w Rzymie w I-II wieku n.e. Owa szkoła metodyków, stosunkowo popularna w medycynie rzymskiej, pozostawała jednak na drugim planie, ustępując szkole humoralnej. Jej pewne ożywienie nastąpiło dopiero we Włoszech w XVII wieku i dało początek jatrofizyce (kierunek ten, opierając się na zdobyczach medycyny, fizyki i matematyki, szukał wyjaśnień dla czynności fizjologicznych organizmu w zasadach fizyki, mechaniki).

Procedury stosowane przez szkołę metodyków, zabiegi hydroterapeutyczne pochodzą od Asklepiadesa: spacery, wycieczki morskie i lądowe, biegi, jazda konna, pływanie, gra w piłkę, śpiew i głośne czytanie, zimne i gorące kąpiele, kąpiele w wodach mineralnych i morskich, masaże za pomocą strumienia wody, masaże suche oraz z wcieraniem substancji leczniczych, wdychanie oparów unoszących się nad źródłami mineralnymi i picie wody mineralnej, wdychanie wyziewów unoszących się ze szczelin w ziemi, nagrzewanie gorącym piaskiem, kąpiele słoneczne, plastry dziegciowe i gorczycowe, wywoływanie wymiotów rzodkwią lub ciemiężycą białą, ostra dieta (kapary, cebula, ocet, pieprz, szczaw, sól i inne), okłady z wody morskiej i ziół, stawianie baniek (Bednarczyk, 1995).

Troska o zachowanie zdrowia w okresie starożytnym była zagadnieniem bardzo istotnym w życiu każdego człowieka. O poradę do ówczesnych medyków udawano się nie tylko w czasie choroby, lecz także będąc zdrowym (głównie patrycjusze, mający niezbędne zasoby finansowe i dysponujący wolnym czasem).

W Rzymie, w przeciwieństwie do Grecji, medykiem mógł być tylko niewolnik. Świadczy o tym fakt, że w tych czasach lekarzy dzielono na dwie grupy: do pierwszej, zwanej medicus - zaliczano teoretyków (Rzymianin mógł do niej należeć), do drugiej, określanej jako artifex - „lekarzy praktyce oddanych”, którymi byli zazwyczaj Grecy (Paciorek, 2013).

Od Greków przejęli Rzymianie nie tylko medycynę, ale także pomysł na łaźnię i jak przystało na mistrzów kreatywności wtórnej - udoskonalili prototyp, a efekt, który osiągnęli, zaskoczył nawet ich samych. Ludzie wolni, niewolnicy, kobiety, dzieci, wszyscy mieli dostęp do widowisk i kąpieli, nie wyłączając cudzoziemców. Najlepszą część życia prywatnego spędzano w zakładach użyteczności publicznej. W każdym mieście była przynajmniej jedna łaźnia publiczna. W V wieku istniało już blisko tysiąc publicznych zakładów kąpielo- 
wych (Chudzikowska-Wołoszyn, 2013). Za niewielkie pieniądze ubogi lud mógł spędzić kilka godzin w luksusowym wnętrzu, które było hołdem złożonym mu przez władze, cesarza lub notablów. Oprócz skomplikowanych urządzeń łaźni zimnych i gorących znajdowały się tam promenady oraz tereny do uprawiania sportów i zabaw (ogrody, biblioteki, sale zebrań, miejsca do jedzenia). Swoje usługi oferowali w nich lub w ich pobliżu uzdrowiciele, cyrulicy i córy Koryntu. $\mathrm{Z}$ początku skromne, funkcjonalne budynki, w których znajdowały się baseny z zimną wodą, krótkie wanny do kąpieli gorących i łaźnia parowa oraz termy, stały się zakładami na wpół rozrywkowymi (Veyne, 2005).

Mimo to kąpiel wraz z rozrywkową otoczką była postrzegana przede wszystkim w kategoriach zdrowotnych. Wierzono, że zdrowe i silne ciało, a wraz z nim także i duszę, można zyskać, zachować i uchronić dzięki wodzie. Stąd starożytni Rzymianie tłumnie odwiedzali miejsca, które cieszyły się mianem uzdrowisk. Od I wieku p.n.e. ogromną popularność zaczęły przeżywać dwie sąsiadujące ze sobą miejscowości - Baje (dzisiaj w obrębie miejscowości Bacoli) i Puteole (dzisiejsze Pozzuoli) leżące nad Zatoką Neapolitańską w Kampanii. Dobroczynną aurę nad tymi miejscowościami roztaczał pobliski wulkan Solfatara. Dzięki niemu dochodziło do licznych ekshalacji siarkowych (wulkanicznych), a w całym regionie obecne były liczne źródła bogate w siarkę. Już w okresie helleńskim tworzące się liczne sadzawki obudowywano kamieniami i wykorzystywano w celach leczniczych. Funkcjonowały tam kąpieliska i sauny, a także studnie $\mathrm{z}$ wodą mineralną. W okresie rzymskim Baje stały się przede wszystkim ekskluzywnym kurortem (Chudzikowska-Wołoszyn, 2013).

Baje i Puteole odwiedzali słynni Rzymianie, m.in.: konsul Gnejusz Korneliusz, który poddał się leczeniu częściowego paraliżu; w 88 roku p.n.e. doradzano Gajuszowi Mariuszowi, aby poddał się kuracji w gorących wodach, co miało być doskonałym remedium na przypadłości reumatyczne. Bywali tu cesarze rzymscy Oktawian August i Neron. Również cesarz Hadrian pospieszył do wód Zatoki Neapolitańskiej z nadzieją na podreperowanie zdrowia, ale niestety zmarł w samym środku sezonu urlopowego w 138 r. Cesarz Aleksander Sewer wzniósł w Bajach pałac i kąpielisko, także cesarz Tacyt miał zwyczaj tu bywać. Cyceron pisał, że w Puteolach zwykle kręciło się dużo najznakomitszych obywateli, sam też tu lubił bywać i dlatego kupił w luksusowym uzdrowisku prywatną willę (Chudzikowska-Wołoszyn, 2013).

Starożytni Rzymianie zdawali sobie sprawę z dobroczynnych właściwości wód siarczkowych. Potwierdzeniem tego mogą być pisma Orybazjusza z Pergamonu (325-403 r.), osobistego lekarza cesarza Juliana Apostaty, który był autorem 17-tomowej encyklopedii medycznej. Jedyna zachowana księga dziesiąta traktuje właśnie o kąpielach leczniczych. Ciepłe siarkowe kąpiele były 
zalecane na wiele przypadłości. Uważano, że zdrowy był nawet dym z siarki. Horacy przyznawał, że źródła z miejscowości Baje leczą mięśnie. Kąpiele w wodach siarkowych były zalecane na wszelkie choroby skórne, na gorączkę, suchoty i dreszcze. Ciepłe sadzawki stwarzały możliwość robienia rozgrzewających kompresów wodnych na łzawiące oczy i obolałą głowę. Wierzono, że gorąca woda pomaga bezpłodnym, a jej picie miało oczyszczać wnętrzności, zapewniały także skuteczną terapię na dolegliwości płuc, wątroby i nerek (Chudzikowska-Wołoszyn, 2013).

Starożytni Rzymianie podróżowali więc głównie do uzdrowisk z gorącymi bądź mineralnymi źródłami, wokół których powstawała infrastruktura. Jednak gdy nie mieszkało się w ich pobliżu, to na taką leczniczą podróż mogły sobie pozwolić tylko osoby zamożne.

Najlepiej znane źródła na terenie dzisiejszej Francji, to: Aquae Calidae Salluviorum (Aix), Aquae Calidae (Vichy), Aquae Bormonis (Bourbon-l'Archaimbault), Aquae Convenarum (Capvern-les-Bains), Aquae Nerii (Néris-les-Bains), Aquae Nisincii (Bourbon-Lancy), Aquae Segetae (Sceauxen-Gâtinais), Aquae Siccae (Cazères, Haute Garonne), Aquae Tarbellicae (Dax) oraz na terenie dzisiejszej Wielkiej Brytanii: Aquae Sulis (Bath) oraz Aquae Arnemetiae (Buxton).

\section{2. Średniowiecze}

Chrześcijaństwo wiele zmieniło na polu medycyny. Głównie poprzez odcinanie się od wierzeń w wielobóstwo. Niszczono wówczas świątynie bogów, palono papirusy i księgi, w tym traktaty medyczne oraz starano się odwodzić ludzi od praktyk stosowanych w Cesarstwie Rzymskim. A ponieważ medycyna, mimo wszystko, była silnie związana z kultami bóstw, zabraniano i tych procedur. Rzymskie łaźnie, ostatnia ostoja higieny i lecznictwa, istniały jeszcze jakiś czas, nawet w klasztorach, jednak coraz częściej były przeznaczane wyłącznie do użytku chorych. Reguła św. Benedykta, spisana około 528 roku dla zakonu łączącego pracę fizyczną z kontemplacją, rezerwowała kąpiele tylko dla osób starych i chorych: „Chorym należy udostępnić korzystanie z łaźni, ilekroć jest to dla nich wskazane; zdrowym zaś, a zwłaszcza młodym, trzeba na to rzadziej pozwalać" (Ashenburg, 2017, s. 60).

Najlepiej prosperowały miejsca, w których Rzymianie zakładali lecznicze termy, czyli tam, gdzie biły gorące lub mineralne źródła. $\mathrm{Z}$ basenów kąpielowych w uzdrowiskach, jak np. w Aix (założone w 122 roku p.n.e. przez rzymskiego konsula Sekstiusza Kalwina jako kolonia weteranów jego wojsk), korzystał Karol Wielki, który zażywał kąpieli ze swoimi gośćmi (niejednokrot- 
nie w kąpieli uczestniczyło około stu osób) (Rouche, 2005). Zmieniając retorykę, pozostawiono ich medyczną moc, wiele z tych wód zaczęto uznawać za święte i budowano przy nich świątynie lub kapliczki. Przykładowo, Rzymianie zbudowali cieplice w Monchique (rzymskie Mons Cicus) i Algavre w Portugali, ale w średniowieczu miejsca te znane były ze względu na święte wody lecznicze (Weisz, 2011). W XVII wieku przejął je Kościół katolicki, zmieniono rytuały kąpielowe, rozbudowano infrastrukturę i zapewniono pomoc w leczeniu. Biedni mogli leczyć się za darmo. W XIX wieku uzdrowiska przejęło państwo, które zapewniło chorym opiekę lekarzy (Baston, 2011).

Wspominane Baje i Puteole opisał w XIII wieku Piotr z Eboli, w heksametrycznym poemacie De balneis Puteolanis. Dzięki niemu poznajemy wiele informacji na temat leczniczego działania wód z rejonu Solfatary. W tym czasie nauki starożytnych powoli wracały do łask, wiedza zawarta w tym poemacie na temat jednostek chorobowych, które leczono przez zażywanie kąpieli lub picie wody, pochodziła od wspomnianego już wcześniej Orybazjusza. Piotr z Eboli opisywał zdumiewające kąpiele, które „otwierały pęcherze”, „opromieniały twarz, wzmacniały pamięć, rozweselały serce, wymazywały brzydkie znamiona z oblicza”. Woda ta „rozluźniała flegmę”, była „przyjaznym lekarstwem na kaszel”, „zraszała członki ciała wysuszone skwarem gorączki”, „służyła na nadmierną potliwość, oddalała uszczerbki nastroju i ociężałość stóp”. W poemacie opisanych jest 35 średniowiecznych kąpielisk w rejonie Pozzuoli. Jak donosili XIV-wieczni uczeni, posiadłość Cycerona w Bajach została zburzona w starożytności, ale we wczesnym średniowieczu w ruinach willi znajdowało się kąpielisko, z którego dobroczynnych właściwości korzystali chorzy i cierpiący. Różnica w funkcjonującym w XIII wieku uzdrowisku, w porównaniu z tym prosperującym w czasach rzymskich polegała na tym, że brak było dawnej sielankowej, nieco rubasznej, atmosfery. Średniowieczne Pozzuoli stało się typowym zakładem medycznym, w którym przede wszystkim szukano pomocy dla chorego i udręczonego ciała. Snobistyczny wcześniej kurort przemienił się w charytatywne sanatorium i stanął otworem dla wszystkich klas społecznych. Najbiedniejsi kwaterowani byli w szpitalach położonym w Tripergole, w pobliżu Pozzuoli. Kuracjusze mogli korzystać ze wszystkich czynnych kąpielisk, gdyż miały one status publicznych (Chudzikowska-Wołoszyn, 2013). Z powodu wybuchów wulkanu większość Baji znajduje się dzisiaj pod wodą.

Podstawą praktyk medycznych był wizerunek ciała i choroby, jaki wówczas funkcjonował. Składały się na niego: obecność rozkładu już za życia, połączenie czystości tego, co żywe i rozkładu tego, co martwe. Gnicie stało się więc jedynym rejestrem, w jakim wyrażała się choroba. Wyobrażenie choroby zdane było też na najbardziej znajome analogie: zapachy i obrazy, a chorobą, 
którą najlepiej było wtedy widać był trąd. Tak więc porównania opierały się na doświadczeniu zmysłowym. Wychodząc od opisów zgnilizny i organów całkowicie pokonanych przez chorobę, porównania te miały uczyć, jak choroby uniknąć. Wpływ tych obrazów pozwala lepiej zrozumieć średniowieczne praktyki medyczne, których podstawowym celem było oddalenie niebezpieczeństwa rozkładu, niedopuszczenie do przeniknięcia zgnilizny do ciała i do jej powstania we wnętrznościach. Wiadomo było na czym polega przenoszenie się choroby, czyli trądu, przypisywało się je kontaktowi z chorym, jego bliskością. Ochrona przed chorobą prowadzi do całkowitego odtrącenia chorego, jego odosobnienia na obrzeżach społeczeństwa (Vigarello, 2011).

Ludzkie ciało stanowiło zatem szczególne miejsce, które mogło istnieć tylko na dwóch biegunach - życia i czystości oraz śmierci i gnicia. Wiązało się to ściśle z dobrem i złem, gdyż jedno było czystością - świętością, a drugie brudem - grzechem. Ciało stanowiło miejsce prawdziwej walki pomiędzy złem i dobrem, pomiędzy chorobą i cudem, czyli boską siłą, częstokroć zawdzięczaną modlitwom kierowanym do świętych. Zabiegi oczyszczające stały się podstawą leczenia i zapobiegania chorobom, przez co woda na powrót została bazą we wszelkich terapiach. Jest to bowiem symbol czystości i zmycia grzechu.

Wyjeżdżano do gorących i mineralnych źródeł, aby zostać wyleczonym z trapiących ciało dolegliwości. Odnawiano rzymskie termy, znajdujące się przy gorących źródłach, np. w Baden pod Zurychem, gdzie zbudowano duże odkryte baseny dla dziesiątek osób. W 1416 roku Gianfrancesco Poggio Bracciolini opisał w malowniczych słowach to, co widział w Baden podczas swojej wizyty w tym miejscu (Braunstein, 2005).

W powieści Flamenca (romans starookcytański z końca XIII wieku) centralnym punktem opowiadania są kąpieliska Bourbon-l'Archambault, w których łaźnie stały się miejscem schadzek kochanków. Były to jednak kąpiele terapeutyczne, a napis umieszczony w każdej z łaźni, informował o jej zaletach. Ściągali do nich chorzy, chromi i kulawi ze wszystkich stron. Każdy basen posiadał źródło gorące i zimne, każdy z nich był odizolowany i zamknięty, a w przylegających doń pomieszczeniach można było odpocząć po zabiegu. Z kąpieli korzystało się w zależności od fazy księżyca. Rozdzieleni od siebie wedle płci, kobiety i mężczyźni brali kąpiele w wulkanicznym źródle o nieprzyjemnym zapachu (Régnier-Bohler, 2005).

Popularnym kąpieliskiem średniowiecznym były Karlowe Wary wybudowane przez cesarza Karola IV Luksemburskiego. Na terenach dzisiejszej Polski pierwsze termy odkryto w Cieplicach, z których już w XIII wieku korzystali książęta świdniccy z rodu Piastów. Ze względu na okoliczne tereny górskie były one bardzo popularne (Małecka, Marcinkowski, 2007). 
Do łask powróciły także łaźnie miejskie, odnawiano łaźnie rzymskie lub budowano nowe. Praktykowano w nich oczyszczanie ciała przez kąpiele, sauny, nacieranie olejkami, ale i upuszczanie krwi, zażywanie środków wymiotnych i przeczyszczających oraz eliksirów, których działanie miało usuwać zepsute humory. Toaleta w owym czasie posiadała walory terapeutyczne, toteż nawet najsurowsze traktaty medyczne zawierają rozdziały poświęcone pielęgnowaniu urody. Przebywając poza domem, czy to w mieście, czy też na wsi, korzystano zazwyczaj z urządzeń publicznych, pozostających najczęściej pod zarządem wspólnoty.

Pielęgnacja ciała stała się zabiegiem zdrowotnym, nie pozbawionym wszakże pewnego uroku. Ówcześnie modna czysta, gładka i błyszcząca na całym ciele skóra, to rezultat częstych kąpieli i żmudnych zabiegów zakończonych namaszczaniem. U schyłku średniowiecza mycie ciała nie wywołuje już takich zastrzeżeń ze strony kościelnych moralistów, jak w początkach chrześcijaństwa, zresztą zwyczaj zażywania kąpieli i łaźni stał się tak powszechny, i to we wszystkich środowiskach, że zalecanie umiaru już by nie skutkowało. Dominikanin Feliks Faber zalecał troskę o utrzymanie czystości ciała, podkreślając również konieczność regularnej zmiany bielizny. Tak więc kobiety i mężczyźni schyłku średniowiecza na znacznie większą skalę niż ich przodkowie korzystali z kąpieli i masaży (Braunstein, 2005).

W XV wieku kuracje cieplicowe stały się zjawiskiem na skalę światową, a znane stacje uzdrowiskowe, takie jak Bad Teinach w pobliżu Stuttgartu, słynąca ze swojego Wildbad („,dzikiego”, czyli tryskającego źródła), przyciągają takich kuracjuszy, jak książę Wilhelm Saski, który bawił tam w 1476 roku ze swoim medykiem, czy też Hall w Tyrolu, której wyszukane instalacje opisywał poseł Agostino Patrizi. Na północ od Alp obyczaj korzystania z łaźni wynikał z dawnych tradycji i cieszył się niesłabnącą popularnością. Włoski traktat o toalecie kobiety, De ornatu, wyjaśnia, iż kąpiel parowa czy też stup his jest pochodzenia germańskiego (sic! faciunt mulieres ultra montanee). W istocie sauna - której prawdopodobnie najstarszy opis dostarcza geograf i dyplomata Ibrahim ibn Jakub, podróżujący w 973 roku przez Saksonię, Czechy i Polskę - jest urządzeniem szeroko rozpowszechnionym w świecie słowiańskim i germańskim. W większości miasteczek łaźnia była oznakowana szyldem przedstawiającym pęk liściastych rózeg i funkcjonowała przez kilka dni w tygodniu (Braunstein, 2005).

Kolejnym elementem w lecznictwie tego okresu, są średniowieczne relikwie, które także należą do kategorii przedmiotów uzdrawiających. Te organiczne szczątki, o których sądzono, że nie ulegają gniciu, chroniły osoby przed fizycznym rozkładem i jego skutkami. Moc świętego przenosiła się na jego grobo- 
wiec, na znajdujące się w pobliżu przedmioty, na wodę, która wypływała spod mogiły, dlatego np. woda świętego Tomasza Becketa była równie cenna, jak otaczająca źródło ziemia. Uważano, że ciała świętych, zwłaszcza po śmierci, przeobrażają się w przedmioty czyste. A niektóre z nich są źródłem materii krystalicznej, jak „łza Pana”, wylana na Łazarza i zachowana w opactwie SaintPierre-lès-Selincourt w diecezji Amiens w końcu XIII wieku. Inne wnoszą ze sobą czystość bardziej wypracowaną, całkowicie przetworzoną przez czynnik święty. Słodkie substancje wydzielające się ze zwłok męczenników mają zawsze właściwości ochronne. Grób świętego Andrzeja wydziela zbierany z nabożeństwem wonny olej, a ciało świętego Marka, przewiezione z Aleksandrii do Wenecji w 468 roku, roztacza intensywny zapach na całe miasto.

Święty przemienia w czyste to, co zazwyczaj postrzega się jako zgniłe. Obraca wszystkie elementy rozkładu w ich przeciwieństwo. Stąd wzięła się tradycja ochronnych właściwości przypisywanych nawet tak wydawałoby się nam niezbyt czystym rzeczom, jak plwocinom świętego Franciszka albo brudowi z jego rak i stóp (Vigarello, 2011). Czy też ślinie świętej Ludgardy, okruchom jedzenia żutym przez świętą Koletę z Corbie, a woda którą mył twarz i ręce święty Eustadiola, przywracała wzrok ślepym. Udawano się po te cenne, uzdrawiające przedmioty daleko, np. z Anglii do Niderlandów po wodę, w której myła się święta Lidwina (Ashenburg, 2017). Przykładów można byłoby mnożyć. Relikwie, rozumiane tak szeroko były kolejnym powodem, dla którego podróżowano. Oczywiście były to podróże lecznicze.

A czemu nie jeżdżono do lekarzy? Należy sobie uzmysłowić, że był to świat, w którym szpital przeznaczano głównie dla biedaków, był on miejscem, gdzie zostawiało się niechciane noworodki i dzieci. Chorzy zamożni pozostawali w swoich łóżkach w domu, tam też cierpieli, konali i umierali. Choroba i umieranie pozostawały w sferze życia prywatnego, doświadczeniami pomnażanymi przez liczebność rodziny, wątłość zdrowia, często spotykaną brutalność zabiegów leczniczych. Wszystkie rodzaje chorób, od przypadków zasłabnięcia po stany niezwykle ciężkie, rozgrywały się w scenerii domu rodzinnego, chociaż w naszych czasach podlegałyby leczeniu w szpitalu. Lekarz udawał się głównie na prywatne wizyty, a i tak w wyobraźni ówczesnych ludzi oraz tekstach medycznych widziany był jako zamiatacz ulic lub rzeźnik.

Mimo tego niepochlebnego portretu, średniowieczni lekarze, na miarę swoich możliwości i w granicach religijności, starali się pogłębiać swoją wiedzę. Ich przedstawiciele oraz amatorzy (np. norymberski medyk Hartmann Schedel), gromadzili zbiory traktatów, w których starożytna wiedza z zakresu medycyny przeplatała się z innymi gałęziami nauki. Obok wiadomości z dziedziny anatomii można w nich znaleźć informacje o właściwościach kamieni szlachetnych, 
znakach zodiaku, astrologii, a także wiedzę z dziedziny farmakopei, magiczne formuły, rozległy obszar wiedzy od gwiazd po próbówkę (Braunstein, 2005). Niestety, wiedza medyków na temat ludzkiego ciała i jego chorób nadal obwarowana była magią i religią, która łączona $\mathrm{z}$ hydroterapiami pozwalała tylko na ograniczoną pomoc w zmaganiu się ze schorzeniami.

\section{Nowożytność}

Medycyna rozwijałaby się zapewne nieprzerwanie, gdyby nie czarna śmierć. Epidemie średniowiecza i wynikająca z nich konieczność odnowienia sposobów ochrony, na parę wieków określą dokładniej wymagania związane z czystością i leczeniem, nie prowadząc jednak ani do lepszego poznania choroby, ani do skuteczniejszego jej opanowania.

Dżuma po raz pierwszy zaatakowała Europę w 1347 roku. Epidemia lat 1347-1350 była pierwszą, najcięższą i najdłuższą, która objęła jednocześnie największy obszar - Europy. Pochłonęła niewyobrażalnie do tej pory wysoki odsetek zmarłych osób.

Simon de Covino, paryski lekarz, w spisanych w 1350 roku wspomnieniach przybliża jej obraz. Pisał, że praktycznie wszyscy lekarze (szczególnie ze szkoły lekarskiej Montpellier) zmarli w czasie tej choroby. Nie przetrwała więc wiedza Hipokratesa, nie było też komu jej przekazywać (Duncan, Scott, 2008).

Rozprzestrzenianie się czarnej śmierci w latach 1347-1350 zmieniło całkowicie nastawienie ludności do tej choroby. Zaraza znalazła we Francji swój dom, swoją bazę. Gdzie indziej stanowiła raczej utrapienie, wybuchając co roku w oddalonych, ale ważnych miejscach. Atakowała głównie w miastach handlowych i portowych, ulokowanych na szlakach lądowych. Natomiast we Francji nigdy nie było okresu wolnego od zarazy, a choroba pojawiała się w różnych miejscach przez następne 300 lat. Kraj ten stał się bastionem choroby i rezerwuarem zakażenia. Wszystkie epidemie atakujące Europę miały we Francji początek. W Europie Północnej i Wschodniej, na Półwyspie Iberyjskim i Półwyspie Apenińskim czy też w Anglii sytuacja była odmienna; w miejscach tych sporadycznie wybuchały epidemie przynoszone przeważnie przez osoby powracające z Francji. Trwały one krótko i szybko znikały, aż do czasu pojawienia się kolejnej zarażonej osoby przyjeżdżającej z Francji (Duncan, Scott, 2008).

W Polsce śmierć z powodu epidemii dżumy zebrała największe żniwo w Krakowie i Gdańsku. Już w 1612 roku wydano w Krakowie: Instructia abo nauka, jak się sprawować czasu moru. Porady zawarte w instrukcji pochodzity z Włoch. Jeżeli chodzi o zarazę, to głównie bazowano na włoskim doświadczeniu. Chociaż wiele z rad, z dzisiejszego punktu widzenia miało rację bytu, jak 
np. 40-dniowa kwarantanna, to niektóre z nich były niezwykle kuriozalne, jak np. zakopywanie się w ziemi po szyję przy pierwszych oznakach zarażenia, co porównywano z padewskimi kąpielami błotnymi, które były jakoby pomocne w przeciwstawianiu się dżumie (Kracik, 1991).

Zmieniło się postrzeganie ludzkiego ciała, które okazywało się narażone na chorobę jako obiekt porowaty, poprzecinany niezliczonymi „przejściami” i otworami. W XIV wieku zaczęto zwracać coraz większą uwagę na powietrze. Wiele zachowań okazało się nagle groźnych, np.: ćwiczenia fizyczne rozgrzewające i otwierające pory ciała - wygrzewanie się nadmiernie otwierało przewody ciała; kąpiele albo folgowanie zbyt częste przyjemnościom zmysłów ü osłabiało wrodzoną siłę. W każdym z tych przypadków zadżumione powietrze mogło przeniknąć do organów i zarazić wszystkie humory.

Chociaż w XVI wieku domyślano się działania mechanizmu zarażenia, to mało jeszcze o nim wiedziano. W tłumaczeniu przyczyn zarazy na plan pierwszy zawsze wysuwało się skażenie powietrza. Wskazywano przede wszystkim na otaczającą przestrzeń. Temat ochrony osobistej miał ciągle charakter ogólny i sprowadzał się do serii działań identycznych, niezależnie od choroby - do utrzymania czystości humorów, jedzenia dobrych mięs, pokrycia podłogi świeżymi ziołami, noszenia w okolicy serca sakiewki z różami, fiołkami, liśćmi mirry, wszystko to w celu lepszej ochrony przed złym powietrzem. Również ubranie na czas zarazy, zalecane przez szesnastowiecznych lekarzy, miało przede wszystkim chronić przed powietrzem: chodziło o obszerne okrycie, które by zamykało wszystkie otwory ciała (Vigarello, 2011). Należało perfumować powietrze lub wdychać specjalne mieszanki ziołowo-kwiatowe, nie wietrzyć pomieszczeń, nie dopuszczać do siebie i mieszkań powietrza, które niesie zarazę. Oczyszczano też owo morowe powietrze ogniem.

Między XVI a XVII wiekiem - gdy zaczął nabierać kształtu ów charakterystyczny lęk przed zarazą - szeroko rozpowszechnione zwyczaje ulegają zmianie: np. łaźnie, którym w czasach dżumy stopniowo zakazywano działalności, znikają z pejzażu miejskiego. Przestano zażywać kąpieli nie tylko w łaźniach publicznych, lecz także w domu. Zmieniły się wyobrażenia o strukturze ciała, co miało ogromny wpływ na jego leczenie. Te nowe praktyki leczenia zasługują na szczególną uwagę - to znaczy te, w których bezpośrednio zaznaczyło się odrzucenie wody. Masowy zanik zażywania kąpieli może prowadzić do wniosku, że w normach higieny nastąpił regres. Co też z naszego punktu widzenia nastąpiło, natomiast z punktu widzenia ludzi renesansu niekoniecznie. Ponieważ ciało jest obiektem porowatym, a woda wchodzi wszędzie, więc powoduje zakłócenia, może wniknąć do ciała, dlatego trzeba obchodzić się nią w sposób szczególny. Z tego powodu od końca średniowiecza do połowy XVIII wieku 
czystość, głównie we Francji, obywała się w zasadzie bez używania wody; jest ona obca ciału, z wyjątkiem twarzy i rąk, jedynych pokazywanych części. Za biegi pielęgnacyjne koncentrowały się wokół tego, co widoczne: ubranie, a przede wszystkim bielizna, której świeżość akcentowana szczególnie kołnierzykiem i mankietami była prawdziwą oznaką czystości. Toaleta powinna więc odbywać się na sucho, została ograniczona do perfumowania się i wycierania poszczególnych części ciała (Revel, 2005).

Obawa przed ukrytą obecnością choroby zwiększała niechęć do korzystania z łaźni. Z czterech łaźni funkcjonujących w Dijon w XIV wieku ostatnia została zburzona w połowie XVI wieku. W tym samym czasie zniknęły także łaźnie w Beauvais, Angers i Sens. Z dokonanego w XIV wieku spisu około trzydziestu łaźni paryskich, zaledwie nieznaczna ich liczba figuruje jeszcze w Wygodnej księdze adresów paryskich z 1692 roku (Vigarello, 2011). Większość łaźni miała charakter leczniczy, a nie higieniczny. W Strasburgu na trzynaście łaźni przetrwały tylko cztery. Martin, którego dziennik z 1637 roku odtwarza życie obyczajowe Strasburga, pisał, że czasami chadzał do łaźni dla „zimnego okładu leczącego zęby i drugiego - na oczy". Bańki, które kazał sobie stawiać na „wysokości ramion”, miały na celu wyłącznie uzupełnienie humorów. Zabieg ten traktował najwyraźniej jako leczniczy. Wywołane podczas niego poty „oczyszczają humory”. W XV wieku zamykanie łaźni było jeszcze oprotestowywane, ale już w XVI wieku zamykało się je oficjalnie i systematycznie. Dochodziły do tego głosy, które rozbrzmiewały już wcześniej, że zakłady te niepokoją jako miejsca kontaktów niepewnych czy po prostu przestępczych, że są to miejsca rozwiązłości i sprzyjające niepokojom. Już na początku XV wieku były one zakazane w Londynie i na jego przedmieściach (Vigarello, 2012).

W pewnych przypadkach mechanizm porowatości ciała przy jednoczesnej zdolności wody do wnikania wszędzie, może się okazać zbawienny, np. w hydroterapii. Zanurzający się w basenach Spa, Pougues czy Forges, w XVI wieku oczekiwali złagodzenia dolegliwości. Kąpiele w wodzie z gorących źródeł, np. rozpuszczają jakoby kamienie: nie inaczej leczono w Montaigne z piasku w moczu. Kąpiele te mogą także sprawić, że organizmy „wyschnięte” odzyskają nieco ciała, nakazywało się takie kąpiele dla „ciał wycieńczonych i wychudłych". Woda oddziałuje też na zabarwienie żółtaczkowe, łagodzi przekrwienia. W tym wypadku powoduje wymieszanie płynów. Wreszcie ich przenikanie może w ostateczności poprawić płyny humoralne - kwaśne lub zepsute. Takie praktyki nawilżają o wiele lepiej niż wszelkie inne medykamenty. $\mathrm{Na}$ ogół jednak kąpiele groziły naruszeniem równowagi. Jest to postawa charakterystyczna dla mieszkańców Francji. W innych krajach wyglądało to podobnie, ale jednak nie bano się wody aż tak bardzo. Pierre Brantôme, francuz, kiedy 
w XVI wieku zwiedzał Szwajcarię dziwił się, że „mężczyźni i białe głowy stykają się pospołu w łaźniach, nie czynią przed się nic sprośnego". Ta towarzyskość była normą w średniowiecznych basenach gorących źródeł, w których zanurzały się nagie ciała osób płci obojga. We Francji takie miejsca zanikły, ale w innych częściach Europy miały się bardzo dobrze. I chociaż nagość wobec drugiej płci była już mniej tolerowana, to nadal korzystano z dobroczynnego działania źródeł (Vigarello, 2012).

Kolejną chorobą zakaźną, jaka pojawiła się w Europie, był syfilis, który odkryto w XVI wieku. Tym razem zarażenie nie miało już być związane z pewnym stanem przyrody, z nieczystością otaczającą ofiary, lecz raczej z jakimś „ziarnem” umieszczonym w ciele tego, kto przekazuje chorobę, z jadem przenoszonym bezpośrednio drogą płciową. Czynnik chorobotwórczy jest niewidzialny, ale chorobę powoduje przekazywanie go przez jedną osobę drugiej. Inaczej mówiąc, już nie niemożliwe do zlokalizowania rozsiewanie, lecz umiejscowione przekazywanie. Co powodowało, że kontakty cielesne były źle widziane. Syfilis, przez swoje zarażanie tylko za pomocą dotyku, był lepiej uchwytny, łatwiejszy do opanowania, ale nadal nieuleczalny.

W Krakowie za Nową Bramą w początku XVI wieku postawiono szpital dla zarażonych pod wezwanie śś. Sebastiana i Rocha (dziś jest tam ulica św. Sebastiana), patronów zarażonych (na wszelkie choroby epidemiczne). Kiedy nie było epidemii dżumy, leczono tam syfilityków, przyjeżdżali wówczas na leczenie ludzie nie tylko z Krakowa i okolic, ale z całego kraju (m.in. z Sandomierza, Częstochowy, Warszawy, ze Lwowa). Czasami szukano po prostu biegłego cyrulika. Kuracja polegała na nacieraniu ciała maścią rtęciową i jego wypacaniu (niekiedy w tym celu wsuwano chorego do nagrzanego pieca) (Kracik, 1991).

Dokonał się także zwrot w stosunku do obiektów leczących. Zestawy cennych przedmiotów traciły na znaczeniu. Przypisywanie mocy zwykłemu kontaktowi z pewnymi substancjami zostawało powoli uznawane za przesąd. Kwestionowano w XVI wieku wiarę w to, że czystość można osiągnąć dzięki samej styczności z czymś, np. z klejnotami, są to pierwsze twierdzenia nowoczesnej nauki, pierwsze odrzucenia pogłosek i krytyka ludowych przesądów. Dotyczyło to nawet relikwii, które już przestały mieć wielką moc - pewność ochrony, jaką miały dawać przestała być oczywista. Reformacja piętnowała ubóstwianie martwych, bałwochwalstwo, wprowadzanie niepotrzebnych pośredników między duszą chrześcijanina a Bogiem. Jan Kalwin poświęcił całą księgę relikwiom, wyliczając fałszerstwa i oszustwa. Kościół w XVI wieku próbował wieku ograniczyć stosowanie relikwii przez poddanie ich reglamentacji. Sobory w Trydencie, Mediolanie i Aix potępiały po 1550 roku zbyt częste posługiwanie się relikwiami i handel nimi. Zabraniały rozdawania relikwii 
i przynoszenia ich do łoża chorego (Vigarello, 2011). Jednak posługiwanie się relikwiami pozostawało nadal praktyką dominującą.

Leczenie w XV i XVI wieku stało się domeną amatorów, w miarę jak garstka akademików zajęła się mglistymi dociekaniami oraz kurowaniem najdostojniejszych pacjentów, z reguły lepiej płatnym niż skutecznym. W czasie epidemii doktorzy ci szukali najczęściej świeżego powietrza i wraz ze swoimi bogatymi klientami udawali się poza miasto. Zostawali na miejscu ci, którzy obsługiwali ogół mieszkańców na co dzień - cyrulicy, czyli felczerzy, ówcześni rzemieślnicy służby zdrowia. W miarę jak lekarze nie podejmowali krwawych zabiegów (duchownych medyków wiązały tu kościelne zakazy), opatrywanie ran przechodziło w ręce łaziebnych i golibrodów (balwierzy). Chirurg taki - cyrulik, wykonywał też czasem trudniejsze operacje. Praca balwierza w przeciwieństwie do zajęć medyka nie wymagała wykształcenia ani znajomości łaciny. Wystarczyły dobre chęci i praktyka.

W XVII wieku w traktatach o zdrowiu ciało jest przedstawiane jako mechanizm. Składa się z obwodów, takich jak serce. Wydaje się mniej podatne niż w średniowieczu na wpływy kosmiczne. Uzyskuje większą autonomię, gdyż rozporządza rozmaitymi stawami i połączeniami. Łatwiej staje się przedmiotem zabiegów, rozmyślnych interwencji, łatwiej daje sobą kierować. Modyfikacje te nie oznaczały gwałtownej poprawy skuteczności zapobiegania chorobie, ani wzrostu liczby wyzdrowień. Umacniało się jednak przekonanie, że oddziałuje się na zrozumiały mechanizm i że można lepiej zapobiec jego defektom. Powoli za nieprawidłowe uznawało się objawy w ciele, których uprzednio za takie nie uważano. Nie znaczy to, że zaczęto określać te choroby, posługując się zweryfikowanymi czy choćby obiektywnymi wskaźnikami. Świadczy to jedynie o pogłębianiu się wrażliwości.

Zwracano też większą uwagę na zdrowotne cechy pokarmów. Kartezjusz opracował w Szwecji dietę, którą uważał za niezawodną. Jego goście przedstawiali ją jako wielkie osiągnięcie, dające nadzieję na „życie przez wiele stuleci” (Vigarello, 2011). Należało jeść co się nam podoba. XVII wiek to czas diet, lewatyw i upuszczania krwi.

W siedemnastowiecznej Francji używanie wody wciąż budziło obawę. W obecności płynu pory muszą się bowiem otworzyć, a w gorącej kąpieli stają się jeszcze bardziej rozchylone. Obawy zrodzone w okresach zarazy pozostały te same: woda przenika ciało i wystawia je na działanie niezdrowego powietrza, otwiera na przestrzał. Kąpiel jest zatem możliwa tylko przy zachowaniu wzmożonych środków ostrożności. Zanurzenie w wodzie jest praktyką rzadką, a nawet niezwykłą. Jedynie częste zmienianie bielizny, która chroni i jednocześnie pochłania zapachy, jest przejawem wymagań zdrowotnych i higienicznych. 
We Włoszech wykształciło się nowe podejście do wody i łaźni mineralnych. W czasach odrodzenia beztroska, populistyczna atmosfera starych łaźni publicznych stała się kłopotliwa, a nawet nieakceptowana. Lekarze z południa postanowili ożywić grecko-rzymskie nauki o kąpielach leczniczych i włączyć je oficjalnie do arsenału swojej profesji. Twierdzili, że medycyna kąpielowa, czyli balneologia, jak zaczęto ją nazywać, jest nauką opartą na racjonalnych podstawach i dysponuje własną metodologią. Odchodzono więc od ich świętej mocy leczącej, a powrócono do argumentów naukowych.

Chociaż włoscy medycy pragnęli porządku i dyscypliny w zdrojach i cieplicach, aby tworzyć atmosferę godną dla nauki, jaką pragnęli wprowadzać, to u schyłku XVI i na początku XVII wieku miejsca te pozostawiały wiele do życzenia. Kuracjusze w Baden nie zwracali uwagi na obowiązujące przepisy, jedząc w kąpieli i przesiadując w wodzie całe dnie i noce „niczym kaczki”. Fynes Moryson, który udał się do Baden w 1592 roku, relacjonował wprawdzie, że siarka zawarta w tamtejszej wodzie potrafi zdziałać cuda w przypadku bezpłodnych kobiet, a także cierpiących na grypę żołądkową i migreny. Jednak ogólny rozrywkowy klimat, pełen nagich ciał, gdzie bywalcy z pełną dezynwolturą ignorowali regulaminy i plany zabiegowe, nie sprzyja leczeniu. Michel de Montaigne sceptycznie nastawiony do lekarskiego kunsztu, ale pełen nadziei, że mineralne zdroje zlikwidują u niego kamienie nerkowe lub przynajmniej złagodzą związane z nimi dolegliwości. Szukając ulgi we francuskich, włoskich i szwajcarskich Spa z uporem ignorował wszystkie lekarskie zalecenia. Był w Plombières-les-Bains (w połowie drogi między Dijon a Strasburgiem) i w La Villa, w pobliżu Florencji, gdzie np. upierał się przy kąpielach i piciu wody w te same zamiast naprzemienne dni oraz wbrew przyjętej ówcześnie praktyce moczył głowę podczas ablucji.

We Francji przedłużeniu powrotu do życia towarzyskiego, utrudnionego wcześniej przez dżumę, sprzyjało w XVII wieku powiększanie się miast uzdrowiskowych i tworzenie nowych, takich jak Bourbon-l'Archambault, Forges-les-Eaux czy Vichy; goście należeli do bardzo wąskiej i bogatej elity. Udawano się na kurację inspirowaną włoskimi naukami - picie wód siarkowych, kąpanie się w nich, do tego natryski i biczowanie wodą. Uznawano owe zabiegi za bardzo męczące i przysparzające cierpień, ale ostatecznie chodziło o zdrowie. Przebywało się tam nie tylko przy dolegliwościach ciała, ale także żeby usunąć „słabości i przygnębienie”. Do Vichy jeżdżono dla zmiany powietrza i wzmocnienia ciała, a ponadto uważano, że tamtejsze wody są „doskonałe na wapory”. Kuracjuszom przyświecała chęć leczenia się bądź zapobiegania chorobom. Znacznemu rozszerzeniu uległo całe spektrum obronne: od chronienia się przed zarazami do zapobiegania waporom (Vigarello, 2011). 
Mimo trudności, włoskie, a za nimi francuskie zdroje zaczęły nabierać coraz bardziej leczniczego i szpitalnego charakteru. Rozmyślnie ascetyczne, jeśli szło o wyżywienie i towarzyskie atrakcje, stały się lukratywnym źródłem dochodu dla zatrudnionych w nich medyków. Zjeżdżali się tam tłumnie kupcy, prawnicy, książęta i zakonnice, z rzadka, dzięki datkom i jałmużnie, pojawiali się także chorzy biedacy, ale przede wszystkim były to przybytki dla osób zamożnych, dla warstw uprzywilejowanych. Kuracja trwała zwykle od 3 do 6 tygodni i często wymagała pobytów dorocznych. We Francji, gdzie uzdrowiska zyskały bardzo na znaczeniu w XVII wieku, powodzenie zapewniał im królewski patronat (Ashenburg, 2017).

W przeciwieństwie do włoskich i francuskich, angielskie uzdrowiska, podobnie jak belgijskie i w krajach niemieckojęzycznych, pełniły w równej mierze funkcje lecznicze, co rozrywkowe i to stale od średniowiecza. Niektórzy goście kurortów, takich jak Tunbridge Wells, Scarborough i Epsom, szukali w nich uzdrowienia i ulgi, a inni flirtowali, chodzili na przechadzki, tańczyli, grali w karty lub kręgle i oddawali się hazardowi.

Najpopularniejszą zdrojową miejscowością w Anglii było Bath, już w czasach preromańskich funkcjonujące jako uzdrowisko, rozbudowane przez Rzymian, w średniowieczu znane jako Akemancastra (miasto chorego człowieka) (Ashenburg, 2017).

Polskie Cieplice w XVI i XVII wieku znane były również w Europie. W 1625 roku bawił tam Stanisław Koniecpolski, stały się też ulubionym kurortem podkanclerza litewskiego Michała Kazimierza Radziwiłła, a także królowej Marii Kazimiery Sobieskiej (Małecka, Marcinkowski, 2007).

Medycyna długo była połączona $\mathrm{z}$ alchemią $\mathrm{i}$ astrologią, a także $\mathrm{z}$ magią i religią, przez co nie zyskała autorytetu. Doszły do tego zarazy, w trakcie których większość lekarzy zmarła. Poza tym wielu z nich wolało być przy zamożnym kliencie, który płacił krocie, głównie za siedzenie przy nim i słuchanie go. Stanisław Staszic pisał pod koniec XVIII wieku, że „dzisiejsza nauka lekarska więcej szkodzi, niż towarzystwu dobrego czyni”, miał na myśli tę samą uczoną medycynę, z jakiej w XIV wieku natrząsali się Francesco Petrarka i Giovanni Boccaccio, w XVI wieku drwił z niej François Rabelais, a w XVII wieku - Moliere (Kracik, 1991, s. 39). Odbudowa lekarskiego autorytetu dopiero się zaczęła, ale musiały minąć jeszcze dwa wieki, aby ludzie zaczęli podróżować w celu skonsultowania się z konkretnym, sławnym lekarzem.

Zachodnim prześmiewcom medycyny wtórowali w XVII wieku rodzimi ironiści. Z twórczości Wacława Potockiego, Krzysztofa Opalińskiego czy Wespazjana Kochowskiego wyzierają przeważnie niebogaci w wiedze, a ciekawi wysokości honorariów medycy, przysparzający raczej umarłych niż zdro- 
wych. Kpiące tony wynikały ze słabości samej medycyny, zwłaszcza jeśli autor doświadczył jej skutków osobiście lub obserwował poczynania szarlatanów, jakich nie brakowało.

Z nadejściem drugiej połowy XVIII wieku tradycyjne cechy humoralne, do których ciągle powracano, traciły na ważności. Powróciły nauki rzymskiej szkoły metodyków, którą na nowo odkryto. Lekarze Pressavin, Roussel, Préville i inni, próbowali zająć się domniemanymi cechami tkanek. Pojawiły się nowe rozróżnienia: ciało o włóknach delikatnych przeciwstawiano ciałom, w których są one mocne, a ciała o włóknach wiotkich - ciałom, w których są one napięte. Powstawały teorie, gdzie materię elektryczną uważano za jedną z głównych przyczyn różnorodności ludzi i ich umiejętności, a ciało jest tylko wielkim nerwem. Bardzo zmienił się system odniesień, prowadząc aż do kwestionowania kanonicznych tekstów Hipokratesa i Galena. Zaczynano mówić o chorobie w kategorii zakłóceń funkcji i energii, która napina ciało i nerwy.

Zmieniały się więc sposoby leczenia. Bardzo znamienne były zwyczaje angielskie, upowszechniające nowe wzorce zachowań: zimna kąpiel, marsz brzegiem morza, surowa dieta - to podstawowe zasady, jakimi kierowali się brytyjscy kuracjusze udający się w połowie XVIII wieku na północ w poszukiwaniu ostrzejszego klimatu. Plaża stawała się miejscem, gdzie należało sprostać wyzwaniu, pokonać leki i apatię. I tak np. seria zanurzeń w prawie lodowatym morzu w Southampton zimą 1747/1748 miała pozwolić odzyskać siły i żywotność pewnemu młodemu pacjentowi Richarda Frewina. Obiektem tych działań były włókna: zanurzenie się w fali oceanu miało je wzmacniać. Czyli nie pływanie, lecz zetknięcie się z zimnem, nie ruch ciała, lecz jego kontakt z wodą. Owa pierwsza kuracja zapoczątkowała serię prób mających dowieść, że morze sprzyja tym osobliwym naprężeniom. Przez wiele lat stawianie czoła falom, rzucanie się w nie, pozostanie podstawą morskich kuracji. Chodziło więc o wywołanie wstrząsu przez zimną kąpiel, o poszukiwanie siły reaktywnej ciała, jego wewnętrznego napięcia (Vigarello, 2011).

Richard Russel dowiódł, że morze jest nie tylko piękne, ale także zdrowe. Wybudował wspaniały dom z widokiem na Kanał La Manche w Brighton, miejscowości wcześniej pogardzanej, która dzięki niemu przemieniła się w jedno najwspanialszych angielskich uzdrowisk. Kuracjusze Russella kąpali się w morzu, najlepiej o piątej nad ranem i popijali morską wodę. Niektórym ordynowano masaże wodorostami oraz natryski z podgrzewanej wody morskiej (Ashenburg, 2017).

Angielskie uzdrowiska przeżywały niesamowity rozkwit właśnie w okresie oświecenia. Do najbardziej znanych należały: Bath, Somerset spa, Cheltenham, Tunbridge Wells, Harrogate, Scarborough, Buxton i Leamington. 
Miejscowości z mineralnymi źródłami dopiero od XVIII wieku określano mianem Spa, od nazwy sławnych gorących zdrojów niedaleko Liège w dzisiejszej Belgii.

Zaczęto krytykować dawny sposób wentylacji, który polegał głównie na: rozpylaniu perfum, oczyszczaniu przemiennym zapachem, zamykaniu się przed morowym powietrzem. Teraz powietrze miało krążyć. Chociaż zniknęła dżuma, to pojawiły się inne choroby zakaźne - ospa oraz gruźlica. Ponownie do łask powróciło powietrze, ale tym razem jako dobroczynny wpływ na pacjentów. Od lat 80. XVIII wieku uznano, że zmiana powietrza może złagodzić u gruźlików wrażenie ucisku na klatkę piersiową. Zalecano więc zmianę powietrza gęstego na rzadsze, wyjazdy na tereny górzyste i nadwodne, pobyt w środowiskach „lekkich i swobodnych eterów". Zainteresowanie powietrzem przyczyniło się do potwierdzenia nowej roli lekarza. Pod koniec XVIII wieku jego status nie jest już taki sam, jak dawniej, inaczej wypełnia on swoją zapobiegawczą rolę: jako człowiek oświecenia żąda możliwości wywierania wpływu na chorego, jakiego dotąd nie miał.

Tej afirmacji zawodu sprzyjał bez wątpienia wzrost liczby praktykujących lekarzy. Dane odnoszące się do Paryża są bardzo znamienne: na początku stulecia było w tym mieście mniej niż stu lekarzy, a w 1780 roku praktykowało już 150, w 1789 roku - 172. Jeszcze wyraźniejszy był postęp, jeżeli chodzi o lekarzy chirurgów: 235 w 1715 roku, 466 w 1789 roku. Zawód ten zdobywał niesłychany prestiż, który potwierdzają kariery osiemnastowiecznych lekarzy (Vigarello, 2011). Lekarze, posiadający większy prestiż, zaczęli głośno potępiać leczenie się samemu, zarówno na wsi, jak i w mieście, gdyż zapobieganie chorobom, podobnie jak ich leczenie, powinno być tylko w gestii lekarza. Zaczęto także zwracać uwagę na zdrowie biednych warstw społecznych, które wcześniej były pozostawione samym sobie.

W I połowie XVIII wieku pojawiły się gabinety fizykoterapii, wraz z niepewnymi próbami i cudami, jakich tam rzekomo dokonywano, m.in. poprzez nacieranie lodem czy kąpiele w zimnej wodzie. Kuracje tego rodzaju miały coraz szersze zastosowanie. Nad Sekwaną w 1761 roku powstał pierwszy zakład bez kąpielowego - była to gorąca łaźnia pompująca wodę z rzeki, aby rozprowadzić ją do niewielkich kabin, rozmieszczonych po obu stronach statku. Organizacja miejsca była nowością, a pomyślano ją tak, aby ułatwić przepływ wody. Sam projekt miał charakter nie tylko leczniczy, ale także higieniczny: „Co krok spotykam chorych, którym kąpiele przyniosły ulgę bądź ich wyleczyły; przyczyniają się one również do zachowania zdrowia”, mówił ich założyciel Poitevin. Ten sposób kąpieli uzyskał aprobatę wydziału medycznego. Jednak ciepłe kąpiele były tylko dla elit. Poitevin powtarzał kilkakrotnie, że należy: „dać bogatym 
okazję do wyleczenia się szybszego, niż gdyby byli oni zmuszeni szukać daleko od swej ojczyzny niezbędnej pomocy" (Vigarello, 2012, s. 131, 132). W tym okresie wzrosło zainteresowanie kąpielami we Francji.

\section{XIX wiek}

Wiek XIX to czas olbrzymich odkryć w wielu dziedzinach, w tym również w medycynie. Dzięki nim nie hamowały jej już tak bardzo religia, elitarność czy strach. Na początku tego okresu we Francji zaczęto wykorzystywać wody mineralne bardziej masowo, nie tylko przez elity (w Aix-les-Bains w 1809 roku przebywało 1200 kuracjuszy), niedługo też odkryto działanie morskich kąpieli (Martin-Fugier, 2006). Dzięki środkom masowego przekazu oraz ulepszeniu transportu kolejowego, zdecydowanie więcej osób zjeżdżało na leczenie do uzdrowisk.

W pierwszej połowie XIX wieku kąpiele, z których korzystali najzamożniejsi stają się bardziej różnorodne: zarówno woda o temperaturze umiarkowanej, jak i woda gorąca ułatwiała energetyzację organizmu, a w dodatku dawała poczucie odprężenia, natomiast woda zimna była stosowana w hydroterapii. Szczególnie polecano kąpiel morską, która stała się popularna w latach 20.-30. XIX wieku, za radami oświeceniowych lekarzy.

$\mathrm{Z}$ wodą należało się mierzyć, wskakiwać do niej na ukos, aby poddać ciało wzmacniającemu wstrząsowi, niekiedy na ciało wylewano kubły słonej wody. Rzesza kąpielowych była wyspecjalizowana w zręcznym chwytaniu kuracjuszy i brutalnym rzucaniu ich na fale, co powtarzano kilka razy. Ten sposób odnosił skutek tylko wtedy, gdy wstrząsy powtarzało się wielokrotnie i do tego w zimnej wodzie. Kąpieliska w tym czasie nie były jeszcze przystosowane do pływania. Nie miały też żadnego związku z czystością. Hydroterapia podążała osobną drogą, zbliżywszy się do higieny w XVIII wieku, niemal do zatarcia granic między nimi, teraz funkcje wody całkowicie się oddzieliły (Vigarello, 2012). Pod koniec XIX wieku do osób korzystających z kąpieli w wodzie dochodzą kąpiele powietrzne i kąpiele słoneczne.

Postępy odnotowane w dziedzinie patologii miejskiej, anarchiczny rozwój przemysłu skłaniały lekarzy do refleksji na temat tego, czy warunki dobrego bytowania nie zostały w sposób radykalny naruszone. Dręczyło to klasy panujące. Lekarze zalecali zmianę powietrza, popierali niezwykle silną odnowę lecznictwa zdrojowego oraz podróże morskie. Pod wpływem szerzenia się gruźlicy wypracowano nową sztukę odpoczynku, którą można nazwać mieszczańską. Pod koniec XIX stulecia pojawiło się przekonanie, że otwarta przestrzeń zapewnia jałowość. Stąd korzyści płynące z wczasów: oddalenie choroby dzięki 
słońcu, wiatrowi, światłu, wzmocnienie systemu obronnego dzięki pobytowi nad morzem, w górach, zabawom na świeżym powietrzu. Wątek ten ogniskował wiele sądów na temat zdrowia: otwarta przestrzeń zabija czynniki zarażające, zabawy przynoszą odporność i energię, podróż przepędza przepracowanie i wycieńczenie.

Wczasy stały się tematem jednoczącym, który łączył praktyki higieniczne z nowymi sposobami wypoczynku, a także społeczne zjawisko spędzania wakacji z naukowymi objaśnieniami, jak chronić się przed mikrobami. Zapewniono nawet osobne miejsce dolegliwościom psychicznym, przy których też zalecany był wyjazd do uzdrowiska. Pobyty na świeżym powietrzu, nieznane wcześniej wsłuchiwanie się w najskrytsze zaburzenia organizmu zachęcały m.in. do zwracania uwagi na zmęczenie i przepracowanie. Nawet opieka społeczna znalazła nowe pole do działania, wysyłając np. najbardziej cherlawych osobników na odpowiedni rodzaj wczasów (Ibidem, 2011). Oczywiście nowe sposoby spędzania wolnego czasu nie brały się tylko z przekonań medycznych. Tłumaczy je przede wszystkim stopniowy wzrost zamożności społeczeństwa. Natomiast argumenty sanitarne pomagały je uzasadnić. Przydawały im powagi i uprawomocnienia. Morze i góry miały być źródłem nieznanych wcześniej energii i dawać niezliczone wskazania, co do ochrony zdrowia.

Przykładowo, Nicea przyciągała zimą rzesze Francuzów, zaletą je był niewątpliwie łagodny klimat, który był zalecany przez lekarzy. Zmianę powietrza, która była modnym sposobem leczenia, lekarze przepisywali gruźlikom, szczególnie pobyty w górach, jak też spędzanie zimy w łaskawszym klimacie. $\mathrm{Na}$ wybrzeżu atlantyckim miasto Arcachon jest skrajnym przykładem owego połączenia lekarskiej opieki z turystyką. Zbudowane w całości w latach 50. XIX wieku jako miejscowość kuracyjna dla gruźlików, posiadało jednak kasyno gry (Martin-Fugier, 2006). W Niemczech w 1900 roku prosperowało 80 sanatoriów ludowych zajmujących się gruźlikami. We Francji w tym czasie było tylko 12 sanatoriów (w 1914 roku). Miejsca te przyjmowały przede wszystkim osoby podatne na gruźlicę, jednak praktyka okazała się daleka od teorii, ponieważ przyjeżdżały tam zwykle osoby już gruźlicą zarażone (Ibidem, 2011).

W XIX wieku zaczęło powstawać wiele uzdrowisk. We Francji na początku stulecia działało 100 Spa, zaś pod jego koniec około 392 takich uzdrowisk. W Wielkiej Brytanii na koniec XIX wieku było ich 92. Najsłynniejsze uzdrowiska Europy tego okresu to: w Czechach - Karlowy Wary i Mariańskie Łaźnie; w Niemczech i Austrii - Baden-Baden, Bad Kissingen, Bad Ems, Bad Homburgvor der Höhe, Wiesbaden, Bad Pyrmont, Bad Ischl, we Włoszech - Montecatini Terme; we Francji - Spa i Vichy; w Anglii - The City of Bath Spa. 
W Polsce w XIX wieku również powstawały uzdrowiska. Licznie odwiedzane były w tym czasie Cieplice wraz z innymi sudeckimi uzdrowiskami, gościły m.in. Wincentego Pola i Seweryna Goszczyńskiego. Na kuracji w Dusznikach przebywał m.in. Fryderyk Chopin. Polacy stanowili jedną czwartą ogółu kuracjuszy, a największe nasilenie kuracjuszy datuje się na pierwszą połowę XIX wieku. Jeszcze w XVIII wieku powstały uzdrowiska w Krzeszowicach i Swoszowicach. W XIX wieku rozkwitło uzdrowisko Krynica, dając początek balneologii, kiedy Józef Dietl (profesor Uniwersytetu Jagiellońskiego uważany za twórcę naukowej balneologii) - rozsławił ten kurort. Rozwój Krynicy w owych latach ilustrują liczby: w 1800 roku leczyło się w tym uzdrowisku 70 osób, w 1850 roku - 131 osób, natomiast w 1880 roku liczba kuracjuszy wzrosła do 3000, a w 1911 roku aż do 11 000, co stało się z powodu otwarcia linii kolejowej z Muszyną (Małecka, Marcinkowski, 2007).

W historii uzdrowisk popularność zyskała Szczawnica, rozbudowana i urządzona w XIX wieku. W 1817 roku gościło w uzdrowisku 49 kuracjuszy, a 18 lat później blisko 3 000. Jednak na początku XX wieku Szczawnica stała się mniej popularna, dopiero wprowadzenie komunikacji autobusowej spotęgowało ponownie jej rozkwit w latach trzydziestych XX wieku (Ibidem, 2007).

Również na terenie Królestwa Kongresowego powstało kilka uzdrowisk ze źródłami mineralnymi, m.in. w Busku Zdroju, Solcu oraz najbardziej popularne w Ciechocinku i Nałęczowie. Dogodne połączenie kolejowe Nałęczowa z Warszawą powodowało duże zainteresowanie mieszkańców stolicy tym uzdrowiskiem, gdzie przebywali na leczeniu m.in. Bolesław Prus, Stefan Żeromski i Henryk Sienkiewicz (Ibidem, 2007).

W 1826 roku Vincenz Priessnitz (którego spolszczone nazwisko dało nam słowo prysznic) otworzył w ośrodek leczniczy w Jesionikach (Czechy). Do śmierci Vincenza w 1851 roku z terapii wodnych zakładu skorzystało 36000 pacjentów. Stosował on terapie wyłącznie wodne. Ponieważ nie skończył żadnej szkoły medycznej, w 1829 roku został przez wielu lekarzy oskarżony o znachorstwo, ale go uniewinniono, gdyż nie używał żadnych leków, ani nawet ziól. Jednak to specjalnie do niego i jego kuracji podróżowano do Jesionik z ogromnych odległości.

Od początku XIX wieku obecność lekarza stawała się coraz powszechniejsza. Nastąpiła kontynuacja zapoczątkowanej w XVII wieku wiary w medyków. W końcu to oni chcą i mogą pomóc chorym. Lekarz rodzinny w kręgach arystokracji, burżuazji czy mieszczaństwa to ktoś do nich podobny, a nawet bliski. Pacjenci oraz ich otoczenie słuchali diagnozy, rozumieli porady, potrafili stosować się do wskazówek zawartych w recepcie, a także dysponowali środkami, by móc przestrzegać higieny, jaką lekarz zalecił. 
W sposób odmienny jawiło się jednak wtargnięcie lekarza - często tego samego człowieka - w życie prywatne rodzin niezamożnych. Przepaść kulturowa dzieląca go w tym wypadku od jego klienta rodziła brak zrozumienia: nakazywała prostotę wyjaśnień i zaleceń. Medycyna taka rozwijała się zatem w atmosferze działań charytatywnych. W środowiskach wiejskich czy biednych, obowiązujące wierzenia odbiegały w sposób radykalny od racjonalizmu i optymizmu oświecenia i nowoczesnej nauki. Choroba wydawała się tym ludziom nadal nieunikniona i nadal często nieuleczalna. Nie mieli oni możliwości wyjazdu, aby zapobiec chorobie lub ratować życie, byłaby to strata czasu i pieniędzy biednej rodziny. Chłop nie starał się znaleźć fizjologicznego jej wyjaśnienia, bo wierzył w medycynę objawów, opierającą się na analogii, jaka panuje w sferze kosmicznej, roślinnej i zwierzęcej. Samo nastawienie do lekarza było dość negatywne i pozostało takie jeszcze czasami w XX wieku.

Zdaniem etnologów, którzy zajmowali się sprawami tradycyjnych zachowań wobec choroby, w XIX wieku funkcjonowała niezwykle żywotna postać medycyny ludowej, polegającej na magicznych zaklęciach oraz staromodnych praktykach. Medycyna ta, opierająca się upływowi czasu, potrafiła umiejętnie zapożyczać z osiągnięć nowoczesnych, nie kwestionując własnej spójności. Uciekanie się do pomocy czarowników i pielgrzymowanie do „dobrych zdrojów” czy też do miejsc, którym patronują „,dobrzy święci”, przetrwało przez cały XIX wiek. Ogromną liczbą pacjentów cieszą się również ci, którzy posiadają pewne umiejętności, np. uzdrowiciele, magowie i znachorzy wszelkiej maści. Posiadają oni sztukę uzdrawiania ciała, często przy użyciu okrutnych praktyk, co kończy się niekiedy tragicznie. Do nich ludzie podróżują, wierząc w ich leczniczą moc.

Jest to wiek, w którym rozpoczęła się bardziej powszechna turystyka medyczna. Polega ona już nie tylko na podróży to uzdrowisk czy miejsc świętych, ale powoli ludzie zaczynają szukać lekarzy specjalistów. Jest to dopiero początek nowoczesnej medycyny, którą możemy cieszyć się dzisiaj.

\section{Zakończenie}

Turystyka medyczna w XX i XXI wieku to już inna historia, ponieważ zarówno podejście do lekarza i chorób, jak i do obywatela zmieniło się diametralnie. Sprawiło to, że chociaż nadal podróżujemy w celach zdrowotnych, jednak poszukujemy czegoś odmiennego niż nasi przodkowie. Oni szukali ratunku od bólu i chorób, których przyczyny najczęściej nie znali, bardziej ufali wierze i magii niż lekarzowi, a to co naturalne stawiali na pierwszym miejscu. Podróżowano więc przede wszystkim do świątyń, świętych miejsc, wód gorą- 
cych i mineralnych, ale robili to głównie ludzie zamożni. I chociaż turystyka to rzecz dość nowa, to w celach medycznych przemieszczano się w odległe rejony znanego świata już od starożytności i to się do dzisiaj nie zmieniło.

\section{Bibliografia}

Ashenburg, K. (2017). Historia brudu. Warszawa: Wydawnictwo Bellona.

Baston, C. (2011). From sulphur to perfume: spa and SPA at Monchique, Algarve. Anthropology \& Medicine 18(1).

Bednarczyk, A. (1995). Asklepiades z Bitynii i szkoła metodyków. Analecta. Studia i materiaty $z$ dziejów nauki 4/1(7).

Braunstein P. (2005). Bliżej intymności. XIV-XV wiek. W: G. Duby (red.). Historia życia prywatnego. Od Europy feudalnej do renesansu. Wrocław-Warszawa-Kraków: Ossolineum.

Chudzikowska-Wołoszyn, M. (2013). Do wód Rzymianie, do wód! O balneoterapii w starożytnych Bajach i Putenolach. W: W. Korpalska, W. Ślusarczyk (red.). Czystość i brud. Higiena w starożytności. Bydgoszcz: Wydawnictwo Naukowe Uniwersytetu Mikołaja Kopernika.

Corbain, A. (2006). Krzyki i szepty. W: M. Perrot (red.). Historia życia prywatnego. Od rewolucji francuskiej do I wojny światowej. Wrocław-Warszawa-Kraków: Ossolineum.

de La Roncière, C. (2005). Życie prywatne toskańskich notabli u progu odrodzenia. W: G. Duby (red.). Historia życia prywatnego. Od Europy feudalnej do renesansu. Wrocław-Warszawa-Kraków: Ossolineum.

Duncan, C., Scott, S. (2008). Czarna śmierć. Epidemie w Europie od starożytności do czasów wspótczesnych. Warszawa: Wydawnictwo Bellona.

First, G. (2013). Woda lecząca - w poszukiwaniu granicy między magią a medycyną w świecie późnego Egiptu. W: W. Korpalska, W. Ślusarczyk (red.). Czystość i brud. Higiena w starożytności. Bydgoszcz: Wydawnictwo Naukowe Uniwersytetu Mikołaja Kopernika.

Kracik, J. (1991). Pokonać czarnq śmierć. Kraków: Wydawnictwo m.

Małecka, B., Marcinkowski, J.T., (2007). Rys historyczny rozwoju lecznictwa uzdrowiskowego. Problemy Higieny $i$ Epidemiologii 88(2).

Marek, A. (2013). Wpływ zjawisk klimatycznych na zdrowie człowieka. W: W. Korpalska, W. Ślusarczyk (red.). Czystość i brud. Higiena w starożytności. Bydgoszcz: Wydawnictwo Naukowe Uniwersytetu Mikołaja Kopernika.

Martin-Fugier, A. (2006). Rytuały życia prywatnego burżuazji. W: W. Perrot (red.). Historia życia prywatnego. Od rewolucji francuskiej do I wojny światowej. Wrocław-Warszawa-Kraków: Ossolineum.

Paciorek, M. (2013). Jak zdrowemu postępować należy, czyli o sposobach zachowania zdrowia za czasów A. Korneliusza Celsusa. W: Korpalska, W., Ślusarczyk, W. (red.). Czystość $i$ brud. Higiena $w$ starożytności. Bydgoszcz: Wydawnictwo Naukowe Uniwersytetu Mikołaja Kopernika.

Régnier-Bohler, D. (2005). Świat fikcji. Ciało. W: G. Duby (red.). Historia życia prywatnego. Od Europy feudalnej do renesansu. Wrocław-Warszawa-Kraków: Ossolineum.

Revel, J. (2005). Poszanowanie obyczajów. W: R. Chartier (red.). Historia życia prywatnego. Od renesansu do oświecenia. Wrocław-Warszawa-Kraków: Ossolineum.

Rouche, M. (2005). Wczesne średniowiecze w zachodniej Europie. W: P. Veyne (red.). Historia życia prywatnego. Od cesarstwa Rzymskiego do roku tysięcznego. Wrocław-Warszawa-Kraków: Ossolineum. 
Veyne, P. (2005). Cesarstwo Rzymskie. W: P. Veyne (red.). Historia życia prywatnego. Od cesarstwa Rzymskiego do roku tysięcznego. Wrocław-Warszawa-Kraków: Ossolineum. Vigarello, G. (2011). Historia zdrowia i choroby, Warszawa: Wydawnictwo Alatheia.

Vigarello, G. (2012). Historia czystości i brudu. Warszawa: Wydawnictwo Alatheia.

Weisz, G. (2011). Historical reflections on medical travel. Anthropology \& Medicine 18 (1). 


\title{
Dorota Matulka ${ }^{1}$
}

\section{Turystyka medyczna \\ - szansą na poprawę efektywności w polskim systemie ochrony zdrowia}

\begin{abstract}
Streszczenie
Celem artykułu jest udzielenie odpowiedzi na pytanie, czy turystyka medyczna o charakterze wyjazdowym może stać się sposobem na problemy dostępności do usług medycznych w polskim systemie ochrony zdrowia? Zakres pracy - obok zobrazowania odczuć samych mieszkańców Polski dotyczących trudności z otrzymaniem świadczeń medycznych - obejmuje także m.in.: prezentację dostępnych rozwiązań dla polskiego obywatela w kwestii wyjazdów na leczenie zagraniczne, rozważania dotyczące wpływu oczekiwania w kolejce do specjalisty na sytuację gospodarczą kraju, jak i samej jednostki ludzkiej. W artykule wykorzystano dane statystyczne pochodzące z różnych ośrodków badawczych, a także dokonano studium literatury.
\end{abstract}

Słowa kluczowe: ochrona zdrowia, turystyka medyczna, dostępność świadczeń medycznych, dyrektywa transgraniczna.

\section{Medical Tourism - An Opportunity to Improve Efficiency in the Polish Healthcare System}

\begin{abstract}
The aim of this article is to answer the question whether outbound medical tourism can be a remedy for the problems of accessibility of medical services in the Polish healthcare system. The scope of the text - besides describing Polish residents' feelings about the difficulty in obtaining medical services - also includes the presentation of available solutions (in terms of foreign treatment) for Polish citizens and considerations about the effect that waiting in a queue to a specialist has

1 Dorota Matulka - mgr, doktorantka, Wydział Zarządzania Uniwersytetu Warszawskiego, ul. Szturmowa 1/3, 02-678 Warszawa, e-mail: matulka.dorota@gmail.com; ORCID: 0000-0001-6346-4302.
\end{abstract}


on the economic situation of the country as well as on the individual human. The article uses statistical data from various research centres and contains a study of literature.

Keywords: healthcare, medical tourism, availability of medical services, cross-border healthcare directive.

\section{Wprowadzenie}

Funkcjonowanie systemów ochrony zdrowia stanowi przedmiot analiz naukowych, głównie ze względu na wciąż pojawiające się nowe wyzwania współczesnego świata. Wzrost mediany wieku ludności, narastające koszty procedur medycznych oraz zwiększające się oczekiwania pacjentów zmuszają do dokonywania nieustannych zmian w zakresie poprawy warunków leczenia i efektywności ekonomicznej (Nojszewska, 2011, s. 49-90). Na stan zdrowia człowieka wpływa wiele czynników w dużej mierze zależnych od decyzji władz państwa, tj. np.: warunki gospodarcze, wydatki publiczne przeznaczane na ten cel oraz od prawidłowego gospodarowania środkami przez decydentów, którym funkcja ta została powierzona. Właściwie działający system ochrony zdrowia winien być priorytetem państw funkcjonujących zgodnie z ideą welfare state. Niestety, duża liczba krajów europejskich, szczególnie położonych w obszarze środkowo-wschodnim, nie potrafi poradzić sobie z licznymi problemami, z których najważniejszy to utrudniony dostęp do świadczeń medycznych. Powszechnym zjawiskiem m.in. w Polsce jest oczekiwanie pacjentów w długich kolejkach do lekarzy specjalistów, czy też na zabiegi medyczne, finansowane ze środków publicznych. Propozycje rozwiązania tego problemu często koncentrują się - z jednej strony na zwiększeniu finansowania ochrony zdrowia w postaci znaczącego podniesienia składki zdrowotnej, na którą nie stać polskich obywateli z powodów niskich dochodów. Z drugiej strony - obejmują wariant zmiany modelu funkcjonowania systemu opieki zdrowotnej w kierunku rozwiązania opierającego się na modelu Beveridge'a, aby ograniczyć głównie koszty, tzw. bramki, polegającej na konieczności filtrowania świadczeniobiorców na tych, którzy mają prawo do nabywania świadczeń finansowanych ze środków publicznych i takich, którzy takiej możliwości nie mają. Niestety, również to rozwiązanie nie gwarantuje osiągnięcia sukcesu, patrząc na przykłady innych państw europejskich, a ponadto w dłuższej perspektywie będzie wymuszało prawdopodobnie podniesienie podatków. Jednak kilka lat temu pojawiła się nowa alternatywa w postaci turystyki medycznej o charakterze wyjazdowym, określanej jako świadomy i niewymuszony wyjazd poza miejsce stałego zamieszkania w celu nabycia świadczenia zdrowotnego 
za granicą w placówce zbiorowej opieki medycznej o charakterze publicznym lub prywatnym, które ingeruje w organizm człowieka. Wyjazd ten może być połączony z tradycyjnym wypoczynkiem, zwiedzaniem i regeneracją sił fizycznych oraz psychicznych. Powstaje więc pytanie, czy turystyka medyczna może złagodzić problemy związane z dostępnością do świadczeń w polskim systemie ochrony zdrowia?

\section{Funkcjonowanie systemu ochrony zdrowia w Polsce a dostępność do świadczeń}

Finansowanie polskiego systemu ochrony zdrowia jest prowadzone głównie w oparciu o składkę zdrowotną, którą tworzą środki pochodzące zarówno od pracownika, jak i pracodawcy (odprowadzającego część składki do ZUS). Większość obywateli ma prawo do nabywania usług zdrowotnych opłacanych ze środków publicznych z tytułu zatrudnienia (składka w wysokości 9\% miesięcznego wynagrodzenia w 2017 roku wpływająca do NFZ w przypadku umowy o pracę). Dostępny zakres świadczeń w ramach płaconej kwoty umieszczono w tzw. koszyku świadczeń gwarantowanych, który obejmuje wyłącznie podstawowe usługi zdrowotne.

Rysunek 1. Wydatki publiczne na ochronę zdrowia

(przedstawione w USD per capita oraz \% PKB) w 2010 i 2015 roku

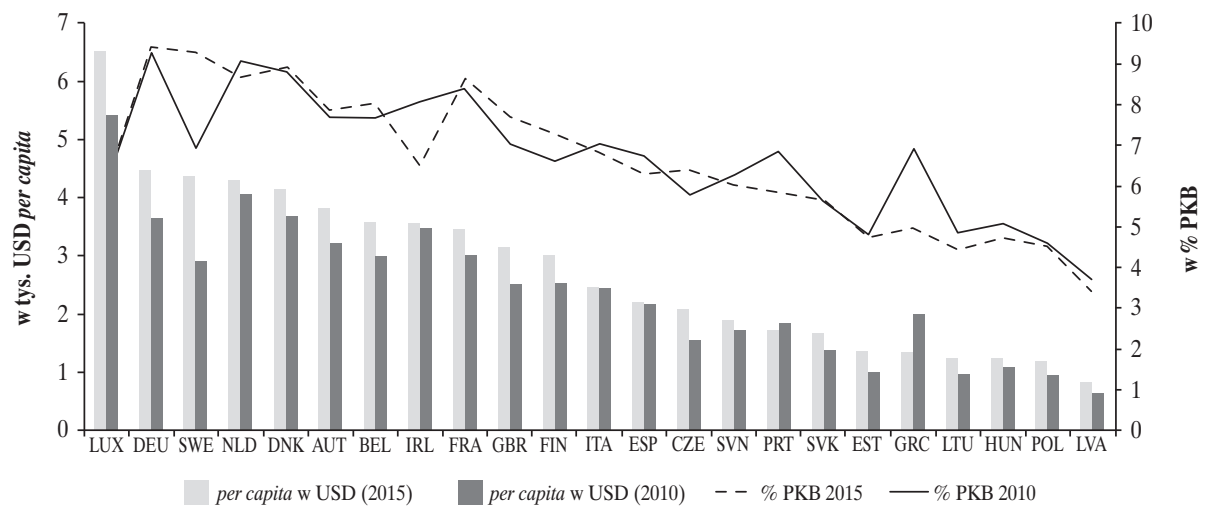

Źródło: opracowanie własne na podstawie danych OECD.

Polskie finansowanie (publiczne) służby zdrowia jest jednym z najniższych w Unii Europejskiej. Na ochronę zdrowia w Polsce w 2015 roku przeznaczono 4,5\% PKB (1,2 tys. USD per capita). W porównaniu np. do Niemiec 
wartość ta była niższa o ponad 3,3 tys. USD w przeliczeniu na jednego mieszkańca. Pomiędzy latami 2010 i 2015, publiczne środki przeznaczane na leczenie polskich pacjentów wzrosły o $25 \%$ w przypadku przelicznika per capita i o 0,1 punktu procentowego PKB. Lecz zmiana ta w porównaniu do większości państw członkowskich UE nadal wydaje się być niewystarczająca.

Ta sytuacja w znaczący sposób wpływa na usługi medyczne poprzez: niskie wynagrodzenia personelu medycznego, jego liczebność, brak postępu w zakresie jakości sprzętu medycznego, który jest ważny ze względu na nowe wyzwania przed którymi stoi współczesny świat, zmniejszającą się rentowność placówek medycznych (najczęstszym problemem zgłaszanym przez środowisko medyczne są niskie kontrakty z NFZ), ich zaopatrzenie i efektywność leczenia. W tej sytuacji - co zauważa pacjent - to tylko niewydolnie działająca służba zdrowia, której symbolem od wielu lat stały się długie kolejki do świadczeń medycznych. Lecz z czego one wynikają? Oczywiście, kwestia finansowania nie jest jedyną przyczyną ograniczonego dostępu do świadczeń medycznych, ale można traktować ją jako jeden z ważniejszych (pośrednich) czynników. Istotne jest tu także np. zachowanie samych pacjentów, którzy rezerwują wizyty „na wszelki wypadek”. W efekcie często rezygnują ze świadczenia - i co najgorsze - nie uprzedzają o swojej nieobecności personelu medycznego. Według jednego z dyrektorów warszawskiej przychodni: $z$ darza się, że na 20 pacjentów zapisanych do jednego specjalisty polowa nie przychodzi i nie uprzedza, ze ich nie będzie. Dla placówki taka „pusta” wizyta to strata, bo jeśli nie byto chorego, nie ma też pieniędzy z Funduszu (Pochrzęst-Motyczyńska, 2016). Ale należy pamiętać, że każdy człowiek z natury postępuje pragmatycznie. Pacjent zawsze będzie poszukiwał szybkiego rozwiązania swojego problemu. Jednak takiego, które będzie cechowała odpowiednia dla niego jakość. Dlatego często zapisuje się u świadczeniodawców mogących wykonać usługę względnie szybko z zachowaniem akceptowalnego poziomu jakości. Mając już pewne miejsce u specjalisty może poszukiwać lepszych możliwości. W momencie znalezienia usługi, która (w jego odczuciu) będzie charakteryzowała się lepszą jakością - zmienia swoją decyzję, zapominając o rezygnacji z poprzedniej alternatywy (niejednokrotnie nie z powodu złych intencji, ale np. przytłoczenia swoim problemem, jakim jest choroba). Oczywiście, nie mam zamiaru usprawiedliwiać tu nieodwoływania zarezerwowanych wizyt, ale zwrócić uwagę na to, że nie jest to wyłącznie wina samych pacjentów, lecz także niezintegrowanego systemu, pozwalającego na nieefektywne wykorzystanie środków publicznych. 
Rysunek 2. Liczba lekarzy i pielęgniarek przypadająca na 1 tys. mieszkańców w 2014 roku

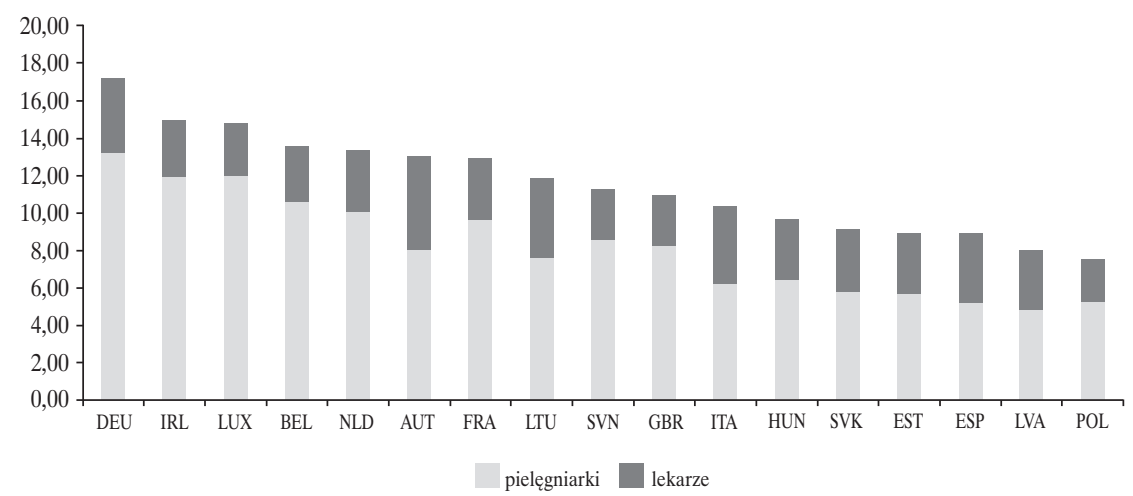

Źródło: opracowanie własne na podstawie danych OECD.

Kolejną kwestią, na którą należy zwrócić uwagę, jest aspekt zasobów. Zestawiając na rysunku 2 liczbę pielęgniarek i lekarzy przypadających na 1 tys. mieszkańców możemy wywnioskować, że Polska dysponuje jednym z najniższych wskaźników liczebności personelu medycznego w UE. Zajmuje bowiem ostatnie miejsce wśród wszystkich wymienionych krajów.

Porównując wyniki badania nt. Opinie o funkcjonowaniu systemu opieki zdrowotnej z 2014 i 2016 roku, w którym zapytano polskich świadczeniobiorców, czy zgadzają się ze stwierdzeniem, że jeśli pacjent tego potrzebuje, to może łatwo dostać się na wizytę do specjalisty. W 2014 roku zaledwie $11 \%$ badanych wyraziło akceptację tego stwierdzenia, aż 85\% - zaprzeczyło (CBOS, 2014). Po upływie dwóch lat, w 2016 roku ten procentowy udział przedstawiał jeszcze bardziej niepokojące wyniki - tylko $8 \%$ respondentów udzieliło odpowiedzi twierdzącej w stosunku do $88 \%$ tych, którzy nie zgodzili się z proponowanym stwierdzeniem (CBOS, 2016).

Rysunek 3. Opinie o funkcjonowaniu systemu opieki zdrowotnej z 2014 i 2016

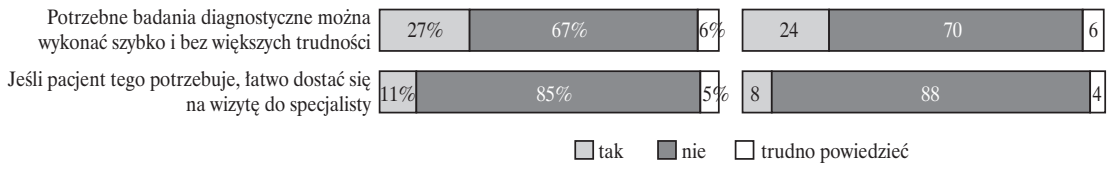

Źródło: CBOS, 2014, s. 2; CBOS, 2016, s. 4.

Natomiast w przypadku wariantu: czy potrzebne badania diagnostyczne można wykonać szybko i bez większych trudności, w 2014 tylko 27\% ankietowa- 
nych udzieliło odpowiedzi pozytywnej, a dwa lata później było ich o 3 punkty procentowe mniej.

Wyniki tych badań potwierdza raport NIK. Nawet wzrost nakładów pieniężnych na służbę zdrowia w Polsce i programy jej naprawy, nie rozwiązały problemu dostępu do świadczeń. Koszty poniesione przez NFZ w 2015 roku były wyższe o 4,4 mld zł i oscylowały w granicach kwoty $67 \mathrm{mld}$ zł. Mimo to kolejki oczekujących pacjentów na niektóre świadczenia znacząco się wydłużyły (Zawadka, 2016).

Przyjrzymy się kilku skrajnym przykładom. Na wizytę w poradniach endokrynologicznych w 2015 roku oczekiwało o $12 \%$ mniej pacjentów w porównaniu do poprzednich lat. Lecz długość pozostawania świadczeniobiorcy w kolejce nie spadła, a wręcz się wydłużyła ze 143 dni do 164 dni (rysunek 4).

Lista czekających pacjentów na przyjęcie na oddział chirurgii urazowoortopedycznej wydłużyła się o 0,5\% z 124144 do 124801 świadczeniobiorców, a czas oczekiwania wzrósł z 107 do 129 dni (o 20,6\%). Sytuacja nie wygląda lepiej także w przypadku świadczeń rehabilitacyjnych, gdzie kolejka oczekujących wydłużyła się z 286 do 348 dni.

Niestety, niektórzy decydenci, zajmujący się ochroną zdrowia w Polsce, raczej wolą marginalizować tę kwestię. Na stronie Konsultanta Krajowego w Dziedzinie Otorynolaryngologii można przeczytać, że: „na podstawie otrzymanych informacji od konsultantów wojewódzkich należy z satysfakcją odnotować, że dostępność do świadczeń medycznych jest dość dobra [...] Należy zaznaczyć, że oczekiwania pacjentów na świadczenia zdrowotne realizowane w ramach hospitalizacji wahają się od kilku miesięcy, do około 3 lat” (Skarżyński, 2015).

Rysunek 4. Liczba osób oczekujących i mediana średniego rzeczywistego czasu oczekiwania do poradni endokrynologicznych w latach 2013-2015, „przypadki stabilne”

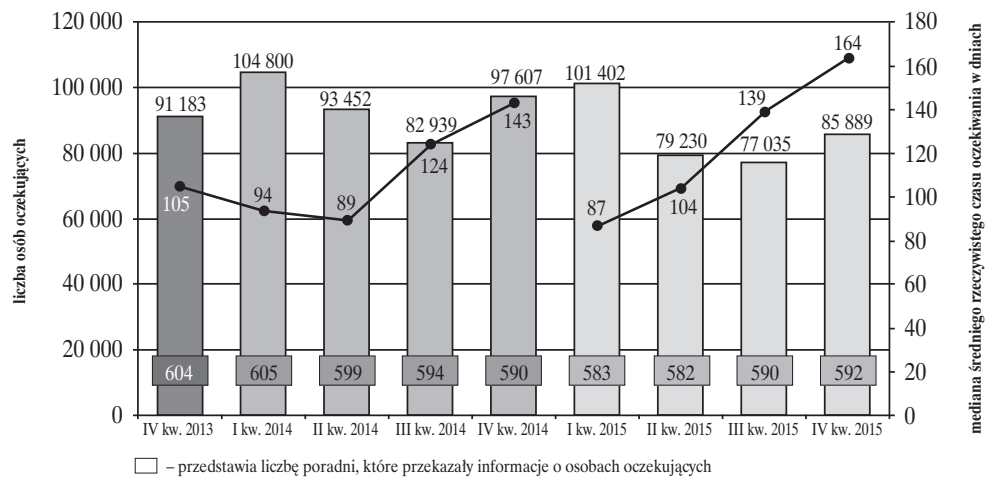

Źródło: NIK, 2016, s. 19. 
Nowocześnie funkcjonujące państwo, które nie może zapewnić pełnej dostępności świadczenia usług powinno korzystać z możliwości, jakie daje mu zglobalizowany świat, wysyłając swoich obywateli m.in. na zagraniczne leczenie. Lecz czy takie rozwiązanie sprawdzi się w polskich warunkach?

\section{Polski obywatel na leczeniu zagranicznym}

Polski pacjent, chcąc leczyć się poza granicami kraju zawsze stanie przed wyborem jednego wariantu $\mathrm{z}$ wachlarza trzech możliwości, tj.:

- leczenie ze środków prywatnych, z których pokrywa się koszt całej usługi;

- leczenie refundowane za zgodą NFZ;

- leczenie w ramach dyrektywy transgranicznej.

Świadczenie bezpłatnej opieki zdrowotnej w nagłych wypadkach jest możliwe w krajach UE/EFTA za okazaniem tzw. Europejskiej Karty Ubezpieczenia Zdrowotnego i przysługuje każdemu jej posiadaczowi w placówkach publicznej opieki zdrowotnej, lecz nie mieści się w zakresie turystyki medycznej, gdyż nie ma charakteru dobrowolnego i nie jest głównym celem wyjazdu.

Rysunek 5. Możliwości leczenia dla polskiego pacjenta za granicą

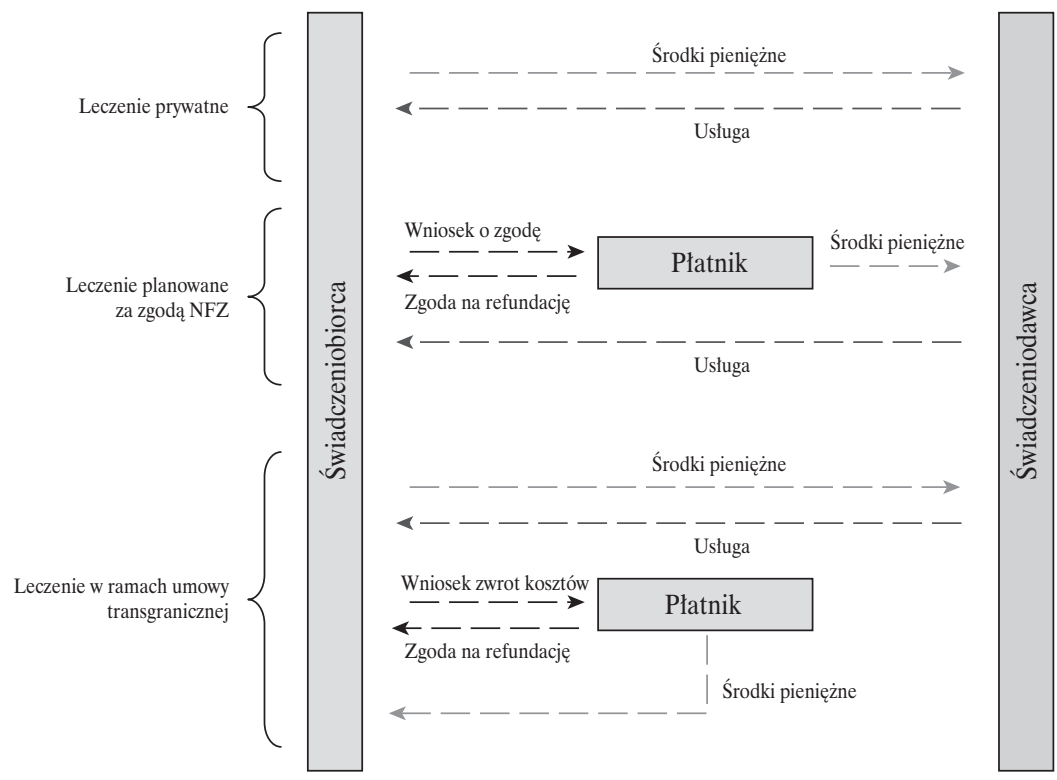

Źródło: opracowanie własne. 
Koncentrując się na leczeniu refundowanym przez NFZ pierwsza możliwość dotyczy tzw. świadczeń planowanych, czyli ściśle określonego i przewidywanego zakresu usług zdrowotnych, wymagający uprzedniej zgody. W myśl ustawy o świadczeniach opieki zdrowotnej leczenie takie poza granicami kraju obejmuje:

- usługi, których nie wykonuje się w Polsce;

- gdy przewidywany czas wykonania świadczenia przekracza dopuszczalny okres oczekiwania świadczeniobiorcy w kraju;

- zabiegi zawarte w tzw. wykazie świadczeń wymagających uprzedniej zgody.

Decyzję (przed leczeniem) o refundacji tego typu usługi podejmuje dyrektor właściwego wojewódzkiego oddziału NFZ na wniosek pacjenta, jeżeli jest to świadczenie, którego nie wykonuje się w kraju - niezbędne też jest uzyskanie zgody Prezesa NFZ.

W 2015 roku Narodowy Fundusz Zdrowia wydał 173 decyzji (z czego: 149 pozytywnych, 22 odmownych i 5 umorzeń), obejmujących planowane leczenie lub badania diagnostyczne poza granicami kraju. Dotyczyły one wyłącznie zabiegów, które nie są możliwe do wykonania w kraju (rysunek 6). Ogólna wartość tych świadczeń szacowana była na kwotę około $34 \mathrm{mln}$ zł (Pęcherz, 2016).

Rysunek 6. Zakresy świadczeń, w których Prezes NFZ wydał w 2015 roku decyzje pozytywne na planowane leczenia poza granicami kraju

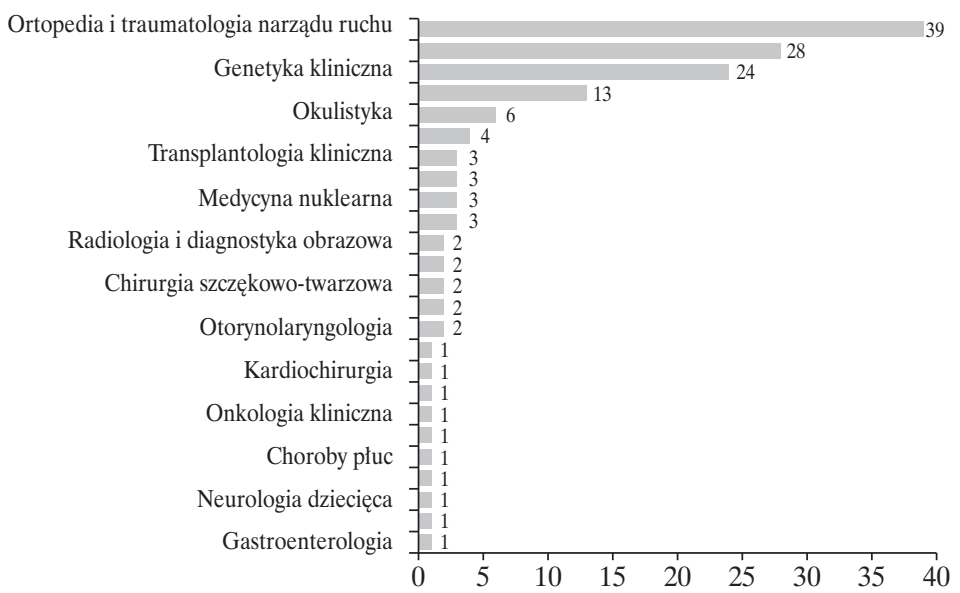

Źródło: Jacyna, 2016, s. 203. 
Drugim rozwiązaniem, które może wykorzystać polski świadczeniobiorca jest leczenie w ramach dyrektywy transgranicznej. Kilka lat temu (w 2014 roku) polski rząd przyjął dyrektywę Unii Europejskiej nr 2011/24/UE z dnia 9 marca 2011 roku w sprawie stosowania praw pacjentów w transgranicznej opiece zdrowotnej (Dz.Urz. UE L 88 z 4 kwietnia 2011 r., s. 45), która umożliwia polskiemu pacjentowi dostęp do świadczeń zdrowotnych w innych krajach członkowskich UE w placówkach (prywatnych i państwowych) zbiorowej opieki medycznej. Wprowadzenie tego rozwiązania miało za zadanie „urzeczywistnić działania Unii Europejskiej w zakresie zapewnienia wysokiego poziomu ochrony zdrowia ludzkiego" (zob. Narodowy Fundusz Zdrowia, 2017).

Z transgranicznej opieki medycznej może skorzystać każdy pacjent mający prawo do świadczeń opieki zdrowotnej finansowanych ze środków publicznych. Przed wyjazdem za granicę nie musi on informować o swoim leczeniu, ani uzyskać zgody od krajowych instytucji. Świadczeniobiorca za usługę medyczną w innym kraju członkowskim UE, płaci z własnych środków, ale po powrocie do kraju może ubiegać się o zwrot kosztów od NFZ. Ważną kwestią jest fakt, że refundację można otrzymać wyłącznie w zakresie leczenia, które jest objęte tzw. koszykiem świadczeń gwarantowanych. Kwota wypłaconych środków świadczeniobiorcy jest obliczana na podstawie cennika państwa, którego jest obywatelem. Ewentualną różnicę w wycenach pokrywa pacjent $\mathrm{z}$ własnego budżetu. Ponadto, zgodnie z przyjętą dyrektywą, ośrodek specjalistyczny do którego zamierza udać się świadczeniobiorca może wymagać, aby spełnił on takie same wymogi dopuszczające do leczenia, jak w kraju, w którym ma prawo do świadczeń zdrowotnych, czyli np. posiadać skierowanie od lekarza rodzinnego. Lecz powstaje pytanie, jak duża liczba Polaków wie o takiej możliwości?

W 2015 roku Komisja Europejska opublikowała specjalne badanie przeprowadzone na liczbie ponad 27 tys. respondentów, pochodzących ze wszystkich państw członkowskich UE, które sprawdzało wiedzę obywateli UE odnośnie do znajomości swoich praw w kontekście nieodpłatnego leczenia poza granicami kraju. Badani otrzymali trzy warianty dotyczące ich praw do otrzymania świadczeń medycznych w innych krajach UE. Mieli wybrać te, które były prawdziwe. Dwa z nich były poprawne: masz prawo do korzystania z opieki medycznej $w$ innym kraju UE, a środki pieniężne, które wydateś, zostana zwrócone przez wtaściwy organ ds. zdrowia w twoim kraju; drugi wariant dotyczył tego, że masz prawo otrzymać kopię dokumentacji medycznej od swojego lekarza, jeśli chcesz podjać leczenie w innym kraju UE. Natomiast wariant nieprawdziwy: nie możesz zrealizować recepty otrzymanej od swojego lekarza w innym kraju UE.

Ponad połowa Polaków wie o możliwości leczenia w innych krajach UE w ramach umowy transgranicznej. Aczkolwiek 34\% respondentów nie umiało 
wybrać żadnego z przedstawionych wariantów. Ponadto, porównując te wartości do wyników obywateli innych krajów UE stopień naszej wiedzy pozwolił na zajęcie przez Polskę ósmego miejsca od końca (rysunek 7).

Rysunek 7. Mam możliwość zwrotu kosztów leczenia przeprowadzonego w innym kraju UE

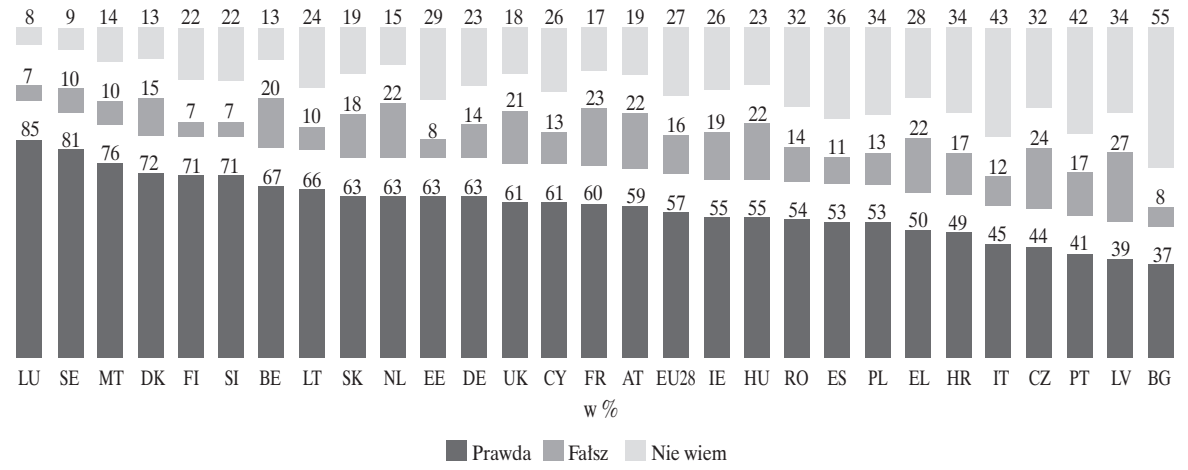

Źródło: European Commission, 2015, s. 10.

Polacy mają względnie wysoką wiedzę na temat prawa otrzymania kopii swojej dokumentacji medycznej od lekarza w kraju, jeśli chcą leczyć się poza jego granicami. Wybór prawidłowego wariantu to $67 \%$ wszystkich udzielonych odpowiedzi. Generalnie w państwach UE jest widoczna duża świadomość w tym zakresie. Wynik uzyskany przez mieszkańców Polski nie jest zły, ale na tle odpowiedzi udzielanych przez innych respondentów wydaje się mało zadowalający (rysunek 8).

Rysunek 8. Mam możliwość otrzymania kopii dokumentów od swojego lekarza, gdy chcę leczyć się za granicą w innym kraju UE

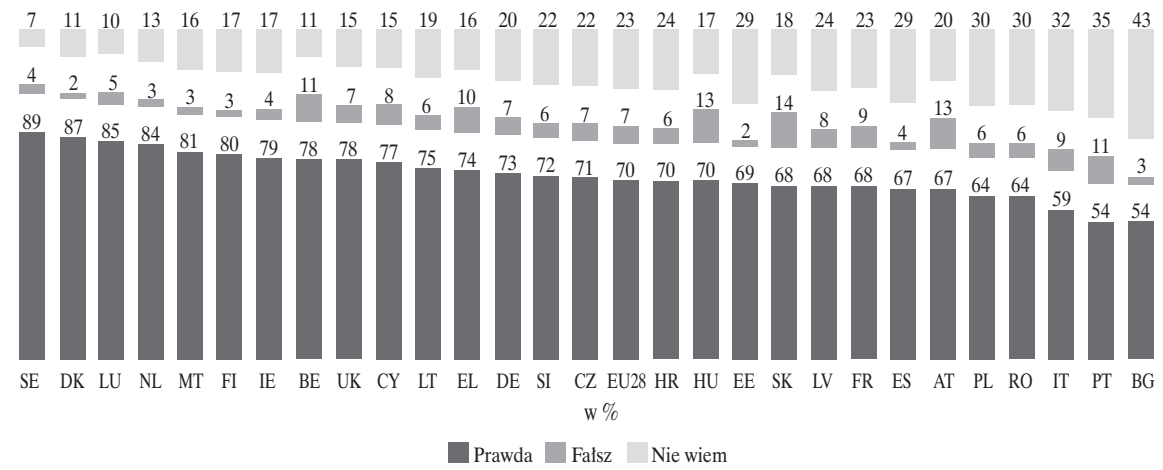

Źródło: European Commission, 2015, s. 11. 
Mniej niż trzech respondentów z dziesięciu spośród wszystkich obywateli UE wie, że receptę otrzymaną od swojego lekarza w kraju może zrealizować poza jego granicami. Podobnie sytuacja kształtuje się w Polsce. Tylko 21\% Polaków wybrało prawidłowy wariant odpowiedzi. Podobnie, jak w przypadku powyższych pytań, Polska zajmuje jedno z ostatnich miejsc wśród krajów UE (rysunek 9).

Rysunek 9. Nie mogę zrealizować recepty otrzymanej od swojego lekarza w innym kraju UE

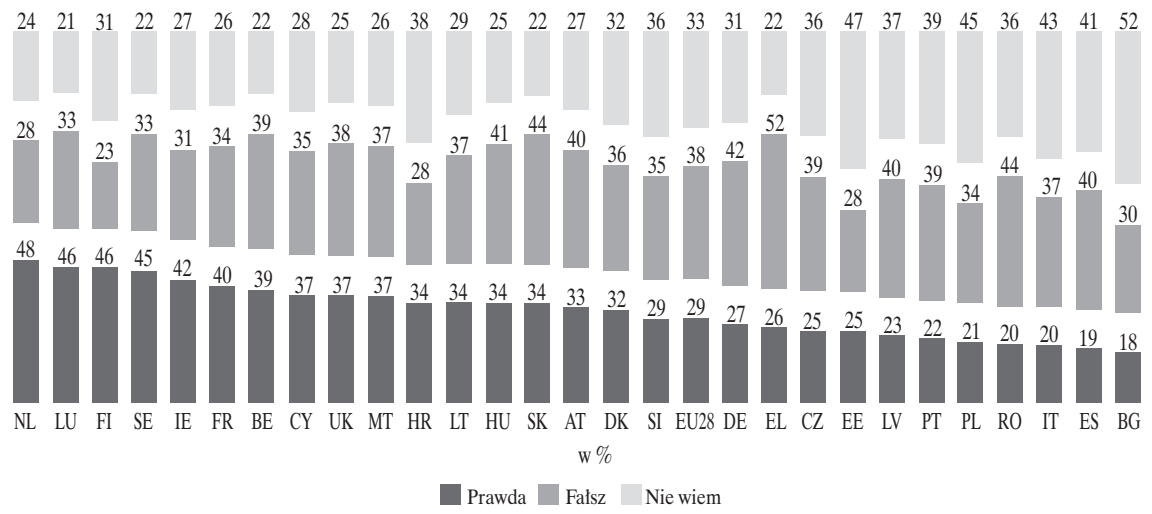

Źródło European Commission, 2015, s. 11.

Rysunek 10. Obywatele UE, którzy udzielili poprawnej odpowiedzi na przynajmniej dwa z trzech zadanych pytań (w \%)

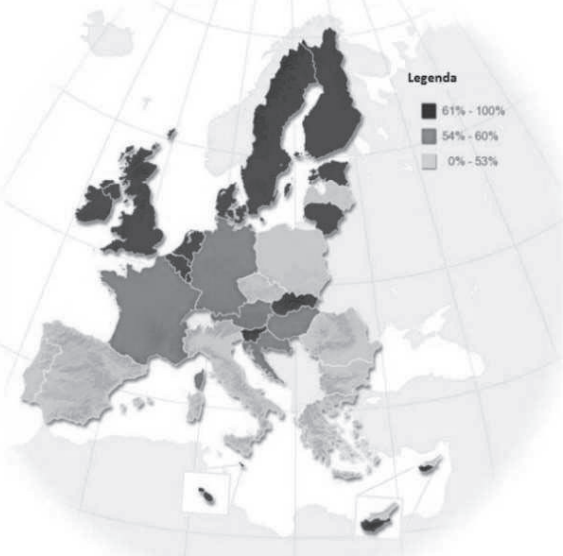

Źródło: European Commission, 2015, s. 12. 
Reasumując, rysunek 10 przedstawia proporcje respondentów, którzy udzielili przynajmniej dwóch poprawnych odpowiedzi spośród trzech zadanych pytań. Jeśli pominiemy pewne wyjątki, widoczny jest wyraźny podział geograficzny. Można przyjąć założenie, że jakość rozumiana, jako wysokie wyniki krajowego leczenia pacjentów częściowo pokrywa się z odpowiednią informacją na temat możliwości wyjazdu za granicę w celach medycznych. Dane te uwidaczniają, że polski obywatel nie dysponuje odpowiednią wiedzą o swoich prawach dotyczących możliwości wyjazdu w celach medycznych do innego kraju członkowskiego UE.

Pomimo niedoskonałej informacji w 2015 roku do wojewódzkich oddziałów NFZ wpłynęło 4872 wniosków dotyczących zwrotu kosztów świadczeń udzielonych naszym obywatelom poza granicami Polski (kraje UE). Kwota do zwrotu z nich wynikająca kształtowała się na poziomie 17741 922,46 zł. Na rysunku 11 można zauważyć (ogólną) tendencję rosnącą liczby składanych wniosków. Tylko miesiące sierpień, maj i czerwiec wykazywały pewne załamanie trendu.

Rysunek 11. Liczba wniosków o zwrot kosztów świadczeń udzielonych w innym państwie członkowskim UE w 2015 roku w poszczególnych miesiącach oraz kwota wnioskowana do zwrotu

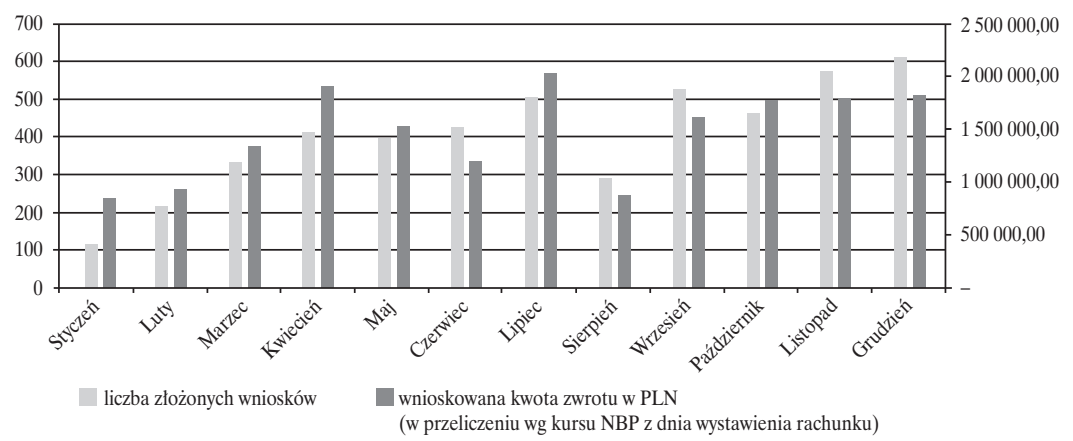

Źródło: Jacyna, 2016, s. 200.

Narodowy Fundusz Zdrowia w 2015 roku zakończył postępowania dotyczące 4100 wniosków ${ }^{2}$, z czego ponad $91 \%$ spraw rozpatrzono pozytywnie. Koszty świadczeń, które zostały zaakceptowane opiewały na łączną kwotę 9272145,76 zł. Jest to niewielka kwota pieniężna w stosunku do środków finansowych, jakie zostają co roku przeznaczane na leczenie krajowe (tabe-

2 W 2015 roku były przyjmowane również wnioski dotyczące zwrotu kosztów na podstawie art. 42b, obejmujące leczenie dokonane w 2014 roku. 
la 1). Jednak - prawdopodobnie - na przestrzeni kolejnych lat wydatki na zagraniczne leczenie będą rosły.

Decyzji odmownych dotyczących zwrotu poniesionych wydatków było około $2 \%$. Do najczęstszych przyczyn wydania negatywnych postanowień należały: ubieganie się o „zwrot kosztów świadczeń, które nie spełniały wymogów określonych w art. 42b ust. 1, 10-12" oraz brak odpowiednich dokumentów, tj. np. skierowanie. Średnia kwota zwrotu kosztów świadczenia w 2015 roku wyniosła 2 477,75 zł (Jacyna, 2016, s. 200).

Tabela 1. Liczba spraw dotyczących zwrotu kosztów świadczeń udzielonych w 2015 roku w podziale na sposób zakończenia sprawy

\begin{tabular}{|l|c|c|}
\hline \multicolumn{1}{|c|}{ Sposób zakończenia postępowania } & Liczba wniosków & Udzial \% \\
\hline $\begin{array}{l}\text { Decyzja pozytywna w sprawie zwrotu kosztów } \\
\text { (art. 42d ust. 1 ustawy o świadczeniach }\end{array}$ & 3747 & 91,40 \\
\hline $\begin{array}{l}\text { Decyzja o odmowie zwrotu kosztów } \\
\text { (art. 42d ust. 2 ustawy o świadczeniach) }\end{array}$ & 82 & 2,00 \\
\hline Decyzja o umorzeniu postępowania & 28 & 0,68 \\
\hline Pozostawienie sprawy bez rozpoznania & 231 & 5,63 \\
\hline Postanowienie o odmowie wszczęcia postępowania & 6 & 0,12 \\
\hline Odesłanie do właściwego oddziału & 1 & 0,15 \\
\hline Wycofanie wniosku przez stronę & 4100 & 0,02 \\
\hline ŁĄCZNIE & & 100,00 \\
\hline
\end{tabular}

Źródło: Jacyna, 2016, s. 200.

Tabela 2. Kwoty zwrotu poniesionych kosztów świadczeń w 2015 roku - według rodzaju świadczenia

\begin{tabular}{|l|c|c|}
\hline \multicolumn{1}{|c|}{ Rodzaj świadczeń opieki zdrowotnej } & Lączna kwota zwrotów w PLN & Udzial \% \\
\hline Ambulatoryjna opieka specjalistyczna & 51677,11 & 0,63 \\
\hline Leczenie stomatologiczne & 1197,02 & 0,02 \\
\hline Leczenie szpitalne - chemioterapia & 49399,90 & 0,60 \\
\hline Leczenie szpitalne - oddziały & 7877571,79 & 95,53 \\
\hline Lecznictwo uzdrowiskowe & 1451,31 & 0,02 \\
\hline Podstawowa opieka zdrowotna & 103,9 & 0,00 \\
\hline Refundacja leków & 3627,58 & 0,04 \\
\hline Świadczenia kontraktowane odrębnie & 188163,77 & 2,28 \\
\hline Świadczenia wysokospecjalistyczne & 56986,79 & 0,69 \\
\hline Zaopatrzenie w wyroby medyczne & 15760,00 & 0,19 \\
\hline ŁĄCZNIE & 8245939,17 & 100,00 \\
\hline
\end{tabular}

Źródło: Jacyna, 2016, s. 201. 
Najczęstszym zabiegiem, jaki wykonywali polscy turyści medyczni w 2015 roku była operacja usunięcia zaćmy. Świadczenie to uwidoczniono w 3133 wnioskach. Zdarzało się, że jeden dokument o zwrot kosztów dotyczył nawet dwóch zabiegów. Dlatego też Narodowy Fundusz Zdrowia dokonał refundacji aż 3271 operacji tego typu. Średnia kwota, która została zwrócona pacjentowi, oscylowała wokół wartości 2210,93 zł. Przeciętna opłata za sam zabieg wykonany za granicą w przypadku standardowego leczenia wynosi od 2500 zł do 3500 zł. Ostateczna kwota, jaką trzeba zapłacić za usunięcie zaćmy jest uzależniona od skomplikowania przypadku i wyboru soczewki. Jeśli jest wymagane wszczepienie np. wieloogniskowej soczewki torycznej (równoczesna korekta astygmatyzmu) - koszty są wyższe. Wtedy za zabieg należy zapłacić od około 4900 do 5500 zł. W związku z tym finansowanie z NFZ wynosi w takim przypadku około $40-44 \%$.

Znaczna część wniosków o zwrot kosztów dotyczyła świadczeń otrzymanych przez polskich turystów medycznych w Czechach (87,65\%), których wypłacona kwota wyniosła ponad $6 \mathrm{mln}$ zł. Ponadto, pacjenci często wybierali także usługi niemieckich szpitali i przychodni. Wnioski obejmujące nabycie świadczeń w tym kraju stanowiły 14,88\% całkowitej ich liczby. Kwota zwrotu kosztów w tym przypadku kształtowała się na poziomie ponad $1 \mathrm{mln}$ zł.

Tabela 3. Liczba dokonanych zwrotów oraz kwoty zwrotu wypłacone w 2015 roku - według państw członkowskich

\begin{tabular}{|l|c|c|c|c|}
\hline \multicolumn{1}{|c|}{ Państwo UE } & Liczba zwrotów & Udzial \% & Lączna kwota zwrotów w PLN & Udzial \% \\
\hline Austria & 6 & 0,18 & 19754,78 & 0,24 \\
\hline Belgia & 2 & 0,06 & 372,05 & 0,00 \\
\hline Cypr & 1 & 0,03 & 2207,37 & 0,03 \\
\hline Czechy & 2917 & 87,65 & 6882663,60 & 83,47 \\
\hline Francja & 6 & 0,18 & 86560,39 & 1,05 \\
\hline Hiszpania & 5 & 0,15 & 6450,60 & 0,08 \\
\hline Holandia & 2 & 0,06 & 228,4 & 0,00 \\
\hline Niemcy & 381 & 11,45 & 1225739,99 & 14,86 \\
\hline Rumunia & 1 & 0,03 & 4674,14 & 0,06 \\
\hline Słowacja & 4 & 0,12 & 13157,85 & 0,17 \\
\hline Wielka Brytania & 3 & 0,09 & 3130,00 & 0,04 \\
\hline LĄCZNIE & 3328 & 100,00 & 8245939,17 & 100,00 \\
\hline
\end{tabular}

Źródło: Jacyna, 2016, s. 202. 
Rysunek 12. Liczba złożonych wniosków i dokonanych zwrotów oraz kwoty zwrotu wypłacone w 2015 roku - według oddziałów wojewódzkich NFZ
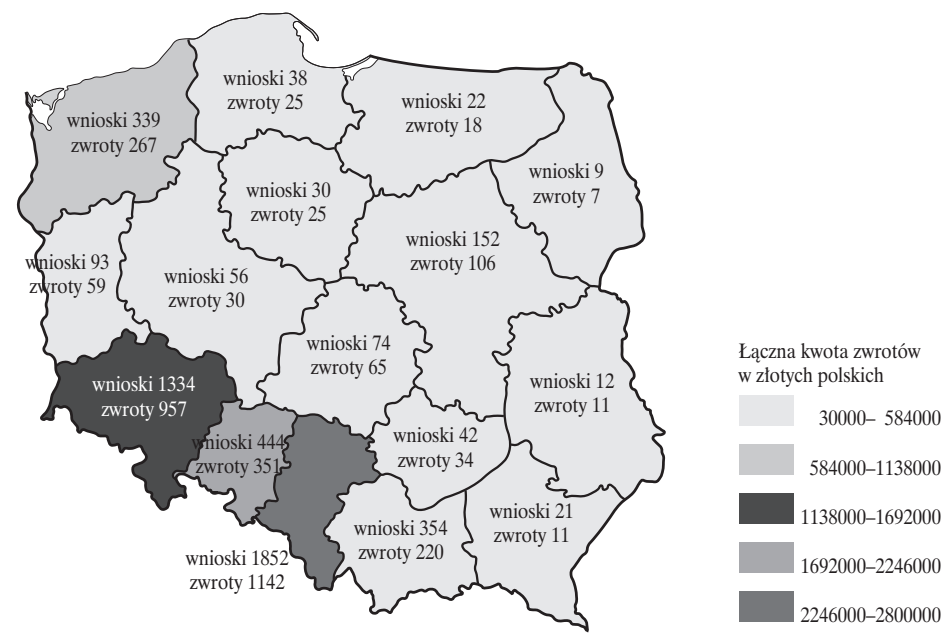

Źródło: Jacyna, 2016, s. 202.

Najwięcej wniosków dotyczących zwrotu kosztów na podstawie art. 42b ustawy o świadczeniach zostało złożone w śląskim oddziale NFZ - aż 1852 dokumentów, z czego wypłat dokonano w 1142 przypadkach. Ich wartość oscylowała w granicach 2 mln zł, co stanowiło 32,78\% całkowitej wielkości kosztów poniesionych przez Narodowy Fundusz Zdrowia na ten cel (Jacyna, 2016).

Jak można zaważyć, na rysunku 12, polska wyjazdowa turystyka medyczna dotyczy głównie województw skrajne zlokalizowanych - szczególnie w pasie przygranicznym z Czechami. Zainteresowanie zabiegami w tym kraju jest bardzo duże. W celu dopełnienia informacji na temat popularności tego kraju odwołamy się do statystyk Google 3 Trends. Hasło „operacja zaćmy Czechy” od momentu wejścia w życie dyrektywy transgranicznej może poszczycić się niesłabnącą popularnością (rysunek 13).

3 Można przyjąć, że dane te charakteryzuje ujęcie procentowe w stosunku do całkowitej liczby wyszukiwań w Google na świecie lub regionalnie - w zależności od ustawień. Jednak taka interpretacja bywa problematyczna. Dlatego lepszym wyjściem będzie traktowanie tych wartości w kategoriach punktowych, gdzie najwyższa popularność danego wyrażenia jest równa 100, a najniższa 0 . Nie jest to bezwzględna liczba operacji. Gdy wyszukiwanie obejmuje wyrażenie, wyniki prezentują statystykę dotyczącą wszystkich żądanych słów w dowolnej kolejności z zachowaniem np. odmiany przez przypadki w języku polskim. Pomijane są synonimy i błędy ortograficzne. Zdarza się także, że połączenia kilku słów zamknięte w cudzysłowie uwidaczniają różne wyniki w stosunku do tych samych wyrażeń z jego pominięciem (HOPE_Publications, 2015). 
Rysunek 13. Zainteresowanie terminem „operacja zaćmy Czechy” od 1 stycznia 2013 do 1 stycznia 2017 roku

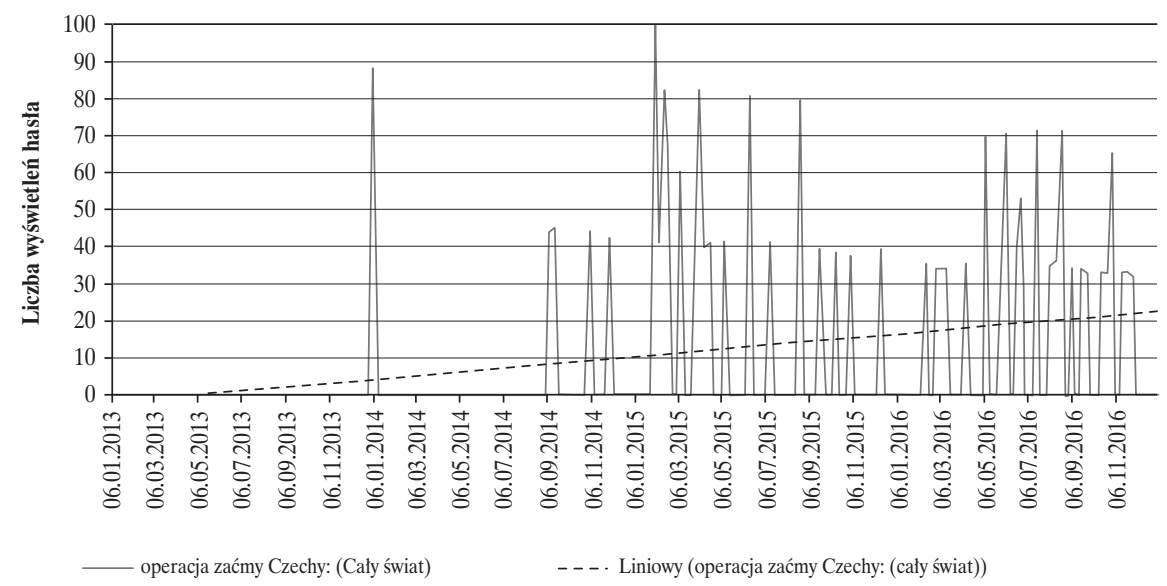

Źródło: opracowanie własne na postawie Google Trends.

\section{Wyjazdowa turystyka medyczna Polaków a gospodarka}

Pojawia się więc pytanie, czy turystyka medyczna może okazać się szansą na poprawę stanu systemu ochrony zdrowia w Polsce?

W ekonomii ochrony zdrowia przyjmuje się, że utrata zdrowia (choroba) jest pewną formą czynnika generującego koszty, szczególnie te o charakterze bezpośrednim i pośrednim.

Koszty bezpośrednie można podzielić na dwie grupy: koszty medyczne (np. wydatki poniesione na zakup sprzętu medycznego i leków, środki przeznaczane na płace personelu służby zdrowia, a także pieniądze, które trzeba wydać na pobyt jednostki w zakładzie zbiorowej opieki medycznej) oraz koszty niemedyczne (np. wydatki związane: ze stosowaniem specjalnej diety, transportem do placówki medycznej oraz opieką nieformalną). Do głównych składników kosztów bezpośrednich zalicza się: opiekę zdrowotną i administrację, leczenie następstw i skutków ubocznych, czas i ból pacjenta oraz czas rodziny, czas i niedogodności dostawcy usług (Hermanowski, Drozdowska, 2013).

Drugą kategorię stanowią koszty pośrednie, które można ogólnie określić, jako utratę lub ograniczenie zdolności do pracy w wyniku choroby. Analiza ekonomiczna powinna uwzględniać wszystkie kanały oddziaływania choroby na podmioty ekonomiczne nie tylko te, które bezpośrednio związane są ze służ- 
bą zdrowia. W ujęciu pośrednim choroba jest jedną z przyczyną zmniejszenia zasobu pracowników w gospodarce. Powoduje ona sytuację, w której jednostka często nie jest zdolna do pracy, co może przekładać się na obniżoną efektywność przedsiębiorstwa, w którym znalazła zatrudnienie. Zmniejszona liczba przepracowanych godzin przez pracownika może wpływać na wielkość dochodów jego gospodarstwa domowego oraz obniżenie środków przeznaczanych na konsumpcję. Połączenie takich czynników, jak: utrata (części) zarobków, niższy poziom konsumpcji w gospodarstwie domowym oraz spadek efektywności produkcji w przedsiębiorstwie wiąże się ze zmniejszeniem wysokości odprowadzanych podatków i składek oraz zwiększeniem transferów wypłacanych przez państwo na rzecz gospodarstw domowych. Efektem finalnym jest pogorszenie się sytuacji sektora finansów publicznych (EY, 2013).

Wielu autorów rozszerza kategorię kosztów pośrednich do tzw. kosztów społecznych, która wówczas dotyczy także strat ogólnie przyjętego dobrobytu społecznego, wynikającego z pogorszenia jakości życia, czy też traconego czasu wolnego oraz zmniejszonej konsumpcji dóbr i usług (Hermanowski, Drozdowska, 2013, s. 13-30). Turystyka medyczna może pomóc w ograniczeniu skutków choroby w tym zakresie.

Koncentrując się na głównych faktach należy stwierdzić, że po pierwsze, polski system ochrony zdrowia nie radzi sobie z tak dużą liczbą osób chorych. Czekając w długich kolejkach oprócz (w większości przypadków) istnienia możliwości pogorszenia się stanu zdrowia jednostki, gospodarka traci w pewnym sensie siły wytwórcze. Patrząc wyłącznie na sferę ekonomiczną i wspomniane wyżej koszty pośrednie - chory pracownik jest nieefektywny. Przez brak zdrowia nie wykonuje obowiązków na miarę swoich możliwości, wykorzystuje system zwolnień lekarskich - w efekcie traci na tym zarówno on sam, jak i przedsiębiorca oraz budżet państwa Teraz odwróćmy tę sytuacje - obywatel nie czeka w kolejce, pobierając świadczenie o wysokiej jakości za granicą, np. w Czechach czy Niemczech. Płaci za usługę z własnych środków i otrzymuje zwrot kosztów, ale do wysokości kwoty, którą i tak budżet państwa (NFZ) wypłaciłby w przypadku leczenia krajowego. Jednostka taka staje się w pełni efektywna w dużo krótszym czasie niż miałoby to miejsce w przypadku pobierania świadczenia w kraju.

W badaniach udowodniono, że zdrowie obywateli w znacznym stopniu przekłada się na sytuację gospodarczą kraju. Analizując ten problem warto przyjrzeć się opisowi matematycznemu, który został zaproponowany przez Marca Suhrcke'a (Hermanowski, Drozdowska, 2013). 


$$
\mathrm{Y}=\mathrm{A} * \mathrm{~F}(\mathrm{KhL})
$$

gdzie:

$\mathrm{Y}$ - produkcja/PKB,

A - wskaźnik TFP (całkowitej wydajności),

$\mathrm{F}$ - funkcja produkcji,

$\mathrm{K}$ - kapitał fizyczny,

$\mathrm{L}$ - praca,

h - kapitał ludzki lub jakość pracy.

Wzrost wskaźnika TFP jest uzależniony od efektywności łączenia czynników produkcji. W związku z tym poziom zdrowia będzie miał tu znaczenie w kontekście naszych działań biznesowych i badawczych. Choroba wpływa negatywnie na aktywność zawodową. Jednostki zdrowsze charakteryzuje najczęściej lepsza wydajność pracy, a tym samym wyższa produktywność w każdej przepracowanej godzinie. Tomasz Hermanowski i Aleksandra Drozdowska twierdzą - na podstawie badań - iż duża część dzisiejszego bogactwa narodów ma swoje źródła w poprawie zdrowia w przeszłości. Wynika z tego, że zdrowie determinuje wzrost gospodarczy (Hermanowski, Drozdowska, 2013).

Oczywiście, ochrona zdrowia nie służy wyłączenie celom ekonomicznym. Leczenie ludzi wynika także - nazwijmy to ogólnie - z pobudek moralnych. Powyższy opis miał tylko charakter przykładowy. To nie pieniądze są w tym wszystkim najważniejsze. Opieka zdrowotna z założenia powinna być dostępna dla wszystkich potrzebujących pomocy. Obecnie polski pacjent leczący się w kraju ma do wyboru dwie możliwości - oczekiwać w kolejce, lub ją ominąć poprzez nabycie usług medycznych prywatnie, co dyskryminuje osoby mniej zamożne. Zasada równej dostępności do świadczeń medycznych zaczyna mieć coraz mniejsze znaczenie. Należy przyznać, że także turystyka medyczna nie jest dla wszystkich, gdyż dotyczy głównie osób, mających dość duże środki własne, pozwalające na pokrycie kosztów świadczeń i transportu. Dodatkowo, konieczność dłuższej podróży, nieznajomości kraju, czasem także języka i kultury w miejscu docelowym - mogą zniechęcać wielu potencjalnych pacjentów oraz zawężać grupę wiekową turystów medycznych. Przykładowo, osoby starsze raczej nie zdecydują się na taki wyjazd. Jednak umożliwienie podróży za granicę zainteresowanym tym rozwiązaniem obywatelom spowoduje zmniejszenie kolejek w kraju, przyczyniając się tym samym do poprawy zdrowia innych grup, które na taki wyjazd nie mogą sobie pozwolić. Odbywa się to bez zmian o naturze systemowej.

Zauważmy, że zagraniczne wyjazdy Polaków to także podróże po jakość otrzymywanych usług. Jeśli istnieje możliwość leczenia w placówkach lepiej 
wyspecjalizowanych, które posiadają zaawansowane technologie i wysokiej klasy specjalistów, to państwo dbające o swoich obywateli powinno stwarzać szanse do tego typu leczenia. Wysoka jakość wykonanej usługi przełoży się na ograniczenie ryzyka nawrotu choroby oraz dłuższą efektywność jednostki zarówno w obszarze społecznym, jak i ekonomicznym.

Ponadto, promocja wyjazdowej turystyki medycznej może przyczynić się do poprawy efektywności także świadczeniodawców. Zarówno instytucje publiczne, jak i przedsiębiorstwa prywatne zetkną się z problemem nowej konkurencji - już nie tylko na rynku krajowym, ale także międzynarodowym. Pacjent z założenia wybierze lepszą dla siebie ofertę pod względem jakościowym oraz cenowym. Placówki państwowe mogą zostać zmuszone do poprawy jakości oferowanych usług, a firmy prywatne do obniżenia cen. W przypadku drugiego wariantu - świadczenia staną się bardziej dostępne dla części osób, które obecnie nie mogą korzystać z takiej możliwości.

Wadą rozwoju wyjazdowej turystyki medycznej jest sytuacja, w której instytucje planujące wydatki w obszarze ochrony zdrowia tracą kontrolę nad środkami przeznaczanymi na leczenie. Tłumacząc to nieco jaśniej - osoba pobierająca świadczenie medyczne w kraju (w pewnym stopniu) ograniczona jest limitami, tzn. może wykonać zabieg w jednostce państwowej, która dysponuje wolnymi środkami, przeznaczonymi na ten cel lub czekać w kolejce. Jest to przeniesienie kosztu w przyszłość. Wyjazdy na zagraniczne leczenie nie są w tym zakresie limitowane. Jeśli wniosek o zwrot kosztów jest poprawnie wypełniony i nie posiada wad natury formalnej - NFZ powinien wydać pozytywną decyzję o zwrocie środków. Gdy „podróże po zdrowie” uzyskają skalę masową - prawdopodobnie - w sposób znaczący przyczynią się do obciążenia budżetu publicznego. Oczywiście, rozwiązanie tego problemu nie będzie łatwe, lecz jest możliwe. Przecież import usług medycznych można (w przypadku Polski) z powodzeniem rekompensować eksportem, który wykorzystałby zasoby placówek medycznych niemożliwe do użycia w ramach niskich kontraktów z NFZ. Wtedy bilans handlowy będzie oscylował w pobliżu zera.

Niestety, turyści medyczni, którzy zdecydują się na zagraniczne leczenie, mogą być narażeni na szereg niebezpieczeństw, z których najpoważniejszym jest błędna informacja. Kluczowym czynnikiem dzięki któremu turystyka medyczna mogła zaistnieć stało się wykorzystanie Internetu. Nawet najlepsze kliniki byłyby pozbawione rzeszy klientów, gdyby nie posiadały odpowiedniej reklamy $\mathrm{w}$ globalnej sieci. Usługi komercyjne stanowią serce turystyki medycznej. W związku z tym, dostęp do zasobów sieciowych i informacji jest tu nieoceniony. Internet stał się łącznikiem pomiędzy świadczeniodawcami a konsumentami. Oferuje on szereg funkcjonalności, do których należą 
m.in. marketing, opinie oraz dzielenie się doświadczeniami przez klientów na forach dyskusyjnych dotyczących danych placówek medycznych, czy też prostotę w dystrybucji usługi z zastosowaniem systemów, tj. CRM4 . Jednak, należy w tym miejscu zwrócić uwagę na pewną kwestię - jakość otrzymywanych informacji. W ostatnim czasie powstaje wiele obaw wobec treści zamieszczanych w Internecie dotyczących turystyki medycznej. Strony www są stosunkowo tanie w konfiguracji i uruchomieniu, a ich treść nie jest regulowana. W związku z tym oferty takie mogą być niedoskonałe lub nie zawsze zgodne z prawdą - nierzetelne, co przekłada się na niebezpieczeństwo „konsumpcji” usług, które stanowią ich przedmiot. Zawsze trzeba wyważyć atrakcyjność tego typu rozwiązań z ryzykiem, które mogą ze sobą nieść (Lunt i in., 2011).

\section{Podsumowanie}

Reasumując, Polska jest krajem, który ma problem z dostępnością do świadczeń zdrowotnych. Rozwiązanie w postaci turystyki medycznej o charakterze wyjazdowym wydaje się być interesującą alternatywą. Jednak jej rozwój może budzić wiele wątpliwości - szczególnie w obszarze kosztów. Jest to w pewnym sensie ominięcie przyjętych rozwiązań systemowych. Pacjenci, wyjeżdżając na zagraniczne leczenie mogą korzystać z zabiegów medycznych na „koszt państwa” w sposób nieograniczony (z wyjątkiem konieczności wyboru usługi z koszyka świadczeń gwarantowanych i posiadania prawa do leczenia ze środków publicznych). Dopóki wiedza polskich obywateli w tym zakresie jest niewielka - wydatki w tej sferze są marginalne. Jednak, jeśli skalę omawianego zjawiska zacznie cechować masowość - rozwiązanie to może okazać się problematyczne dla budżetu państwa, który - już w tym momencie - jest znacząco ograniczony. Jednocześnie ważne jest także dobro pacjenta, który powinien mieć możliwość leczenia w sposób właściwy (godny). Jest to wybór pomiędzy odpowiednim gospodarowaniem środkami finansowymi a moralnością. Powstaje zatem pytanie, co jest ważniejsze? Oczywiście polski obywatel ma prawo także do korzystania w kraju z usług prywatnych, które są lepsze jakościowo i pozbawione kolejek. Jednak, czy w ten sposób nie zmusza się go do płacenia za swoje zdrowie dwa razy? - państwowo (w postaci składki, z której i tak nie korzysta) i prywatnie. Wyjeżdżając na zagraniczne leczenie przynajmniej w sposób częściowy odzyskuje zapłacone wcześniej pieniądze od NFZ, co nie byłoby możliwe w przypadku prywatnego leczenia krajowe-

4 CRM (Customer Relationship Management) na potrzeby artykułu rozumiany jest jako system informatyczny, służący do zarządzania relacjami z klientem, który wspiera i automatyzuje pracę na linii klient - przedsiębiorstwo. 
go. Dodatkowo, nie zajmując kolejki przyczynia się do jej skrócenia, dając możliwość pomocy innym osobom, które - z różnych przyczyn - nie mogą sobie pozwolić na podróż zagraniczną, a sam staje się dużo szybciej efektywny (zdolny do pracy) nie tylko dla siebie, ale także dla gospodarki. Pozostaje jeszcze jedna kwestia do omówienia, czyli sytuacja drugiej strony systemu ochrony zdrowia - świadczeniodawców. Czy rozwój turystyki medycznej wpłynie negatywnie na jednostki publicznej i prywatnej opieki zdrowotnej? Zapewne nie uzyskamy jednoznacznej odpowiedzi na to pytanie. Kontrakty z NFZ są ograniczone, tzn. w ramach określonej kwoty (bez zadłużenia) można wykonać daną (nieprzekraczalną) liczbę usług. Nie miejmy złudzeń, że w przyszłości zaistnieje sytuacja, w której (przez turystykę medyczną) pojawi się w szpitalach i przychodniach znacznie mniejsza liczba pacjentów niż ta wynikająca z kontraktu, gdyż duża część naszych obywateli jest zmuszona do leczenia w kraju, ze względu na swoją sytuację materialną lub życiową. W tym przypadku turystyka medyczna nie jest zagrożeniem. Jednak jeśli zwrócimy uwagę na jednostki prywatne świadczące usługi zdrowotne - problem wydaje się być oczywisty. Tego typu przedsiębiorstwa (w szczególności zlokalizowane w zachodnim i południowym pasie przygranicznym) zetkną się z zupełnie nowym typem konkurencji - zagranicznymi jednostkami, które zazwyczaj są na dużo wyższym poziomie rozwoju pod względem: nowoczesnych metod leczenia, podejścia do pacjenta i szeroko rozumianej jakości świadczonych usług. Powstanie sytuacja, w której firmy te zostaną zmuszone do poprawy poziomu swojej oferty, lub obniżenia ceny. Zarówno w pierwszym, jak i w drugim przypadku w efekcie skorzysta na tym pacjent, a także (w pierwszym wariancie) jednostki publiczne, które (nawet w przypadku niechęci) będą musiały podążać za tą jakością. Może wtedy zmodernizowane polskie kliniki sprawią, że lekarze i pielęgniarki będą chętniej pracować w kraju. Pewne jest jedno - aby silnie rozwijać turystykę wyjazdową na masową skalę należy skoncentrować się także na tej o charakterze przyjazdowym. Tylko w ten sposób możliwe jest zabezpieczenie przed bardzo wysokim obciążeniem budżetu.

Należy przyznać, że turystyka medyczna (dla licznego grona osób) charakteryzuje się zapewne taką samą liczbą wad, jak i zalet. Jednak jej powstanie wynika z wyzwań obecnych czasów. Niestety, nawet jeśli jesteśmy jej zagorzałymi przeciwnikami - ona i tak będzie się rozwijać coraz szybciej. Ideą ojców założycieli Unii Europejskiej, której jesteśmy członkiem, było stworzenie regionu bez granic. Turystyka medyczna idealnie wpisuje się w ten sposób myślenia. W związku z tym grzechem byłoby niewykorzystanie tej szansy. 


\section{Bibliografia}

EY (2013). Medtodyka pomiarów kosztów pośrednich w polskim systemie ochrony zdrowia. Warszawa: EY.

CBOS (2014). Opinie o funkcjonowaniu systemu opieki zdrowotnej nr107/2014. Warszawa: CBOS.

CBOS (2016). Opinie o funkcjonowaniu systemu opieki zdrowotnej nr113/2016. Warszawa: CBOS.

European Commission (2015). Patients' rights in cross-border healthcare in the European Union; Eurobarometer 425. Brussels: European Commission.

Hermanowski, T., Drozdowska, A. (2013). Ocena wartości życia i zdrowia, pomiar korzyści związanych z technologiami medycznymi, rodzaje kosztów w opiece zdrowotnej. W: T. Hermanowski (red.). Szacowanie kosztów spotecznych choroby $i$ wplywu stanu zdrowia na aktywność zawodowa i wydajność pracy. Warszawa: Wolters Kluwer Polska.

HOPE_Publications (2015). Medical Tourism. Belgium: HOPE Publications.

Jacyna, A. (2016). Sprawozdanie Narodowego Funduszu Zdrowia za rok 2015. Warszawa: Narodowy Fundusz Zdrowia.

Lunt, N., Smith, R., Exworthy, M., Green, S.T., Horsfall, D. i Mannion, R. (2011). Medical Tourism: Treatments, Markets and Health System Implications: A scoping review. Paris: OECD Publications Service.

Narodowy Fundusz Zdrowia (2017). Leczenie w innym państwie członkowskim UE wynikajace $z$ dyrektywy transgranicznej. Pobrano z lokalizacji Krajowy Punkt Kontaktowy do spraw transgranicznej opieki zdrowotnej: http://www.kpk.nfz.gov.pl/pl/leczenie-w-innym-panstwie.html (dostęp: 20.12.2017).

NIK (2016). Realizacja zadań przez Narodowy Fundusz Zdrowia w 2015 roku. Warszawa: Najwyższa Izba Kontroli.

Nojszewska, E. (2011). Funkcjonowanie systemu ochrony zdrowia w Polsce na tle wybranych krajów europejskich. W: Ryć K., Skrzypczak, Z. Ochrona zdrowia na świecie. Warszawa: Wolters Kluwer.

Pęcherz, T. (2016). Funkcjonowanie dyrektywy o transgranicznej opiece zdrowotnej w warunkach polskich. I Krakowski Kongres Turystyki Medycznej. Kraków.

Pochrzęst-Motyczyńska, A. (2016). NFZ. Pacjenci nie odwołują umówionych wizyt. Kolejki coraz dłuższe. Gazeta Wyborcza z 28 kwietnia.

Skarżyński, H. (2015). Konsultant Krajowy w Dziedzinie Otorynolaryngologii. Pobrano z lokalizacji: Ocena dostępności świadczeń zdrowotnych: http://konsultant-krajowy.pl/inicjatywy/ ocena-dostepnosci-swiadczen-zdrowotnych/ (dostęp: 20.12.2017).

Zawadka, G. (2016). Kolejki do lekarzy specjalistów coraz dłuższe. Rzeczpospolita z 24 listopada. 
Greta Kanownik ${ }^{1}$

\title{
Znaczenie rankingów w kształtowaniu konkurencyjności szpitali - wyniki badań własnych
}

\begin{abstract}
Streszczenie
Obecnie rankingi stanowią nieodzowny element informacji dostępnej dla klientów i właścicieli firm o pozycji konkurencyjnej danego przedsiębiorstwa, branży czy kraju. Do korzyści, wynikających z dokonywania porównań placówek medycznych między sobą, można zaliczyć m.in.: pomoc w uzyskaniu większego stopnia satysfakcji klientów, umożliwienie identyfikacji deficytów, zrozumienie przez zarządzających powstałych deficytów i dążenie do doskonalenia procesów w organizacji w celu zwiększenia ich skuteczności i konkurencyjności, zwiększenie potrzeby wdrażania zmian, umożliwienie wyznaczania trendów i kierunków rozwoju.

Rankingi odgrywają także dużą rolę w kształtowaniu konkurencyjności na rynku medycznym. Dzięki nim pacjent ma możliwość uzyskania wiarygodnych informacji o szpitalu i dokonania świadomego, opartego na rzetelnej wiedzy, wyboru szpitala, w którym chce być leczony. W części teoretycznej opracowania dokonano przeglądu rankingów szpitali realizowanych na świecie z rankingiem „Bezpieczny Szpital” realizowanym przez CMJ w Polsce. Przedstawiono mankamenty polskiego rankingu konkurencyjności szpitali oraz zaproponowano główne kierunki, rekomendacje pomiaru w oparciu o dokonaną analizę rankingu polskiego z rankingiem stosowanym w Szwecji oraz wyników uzyskanych z przeprowadzonego badania własnego.
\end{abstract}

Słowa kluczowe: konkurencja, konkurencyjność, ranking, Indywidualne Wywiady Pogłębione (IDI).

1 Greta Kanownik - dr, kierownik Działu Dokumentacji Medycznej Samodzielnego Publicznego Zespołu Opieki Zdrowotnej w Brzesku, ul. Tadeusza Kościuszki 68, 32-800 Brzesko, e-mail: g.kanownik@interia.pl. 


\title{
The Role of Rankings in the Shaping of Hospital Competitiveness. Research Report
}

\begin{abstract}
Currently, rankings are an indispensable element of information about the competitive position of a given company, industry or country, available to customers and business owners. Benefits of comparisons of medical facilities include: assistance in achieving a greater degree of customer satisfaction, identification of deficits, managers' understanding of emerged deficits and attempts to improve processes in the organisation in order to increase their effectiveness and competitiveness, increased need to implement changes, possibility of setting trends and development paths.

Rankings also play a considerable role in shaping competitiveness on the medical market. They allow patients to obtain well-founded information about hospitals and make a conscious choice of the hospital to treat them, based on reliable knowledge. The theoretical part reviews the rankings of hospitals in the world together with the ranking "Safe Hospital" prepared by the Polish Healthcare Quality Monitoring Centre. The shortcomings of the Polish ranking of hospital competitiveness are presented. Moreover, the main directions, measurement recommendations are proposed based on the analysis of the Polish ranking, the ranking used in Sweden and the results of my own research.
\end{abstract}

Keywords: competition, competitiveness, ranking, Individual In-depth Interviews (IDI).

\section{Wprowadzenie}

Konkurencja jest głównym elementem sprawnie funkcjonującego rynku, jest niezbędna do rozwoju oraz stanowi motywację do tego, aby osiagnąć zamierzony cel i sukces. Z praktyki gospodarowania w warunkach rynkowych wynika, że w najkorzystniejszej sytuacji znajdą się te podmioty, które systematycznie dążą do umacniania swojej pozycji na rynku, są elastyczne w działaniu i stosowaniu nowych metod zarządczych. Rozpatrując problematykę konkurencji w ochronie zdrowia, należy wziąć pod uwagę fakt, że sektor ten stanowi specyficzny dział gospodarki. Nie może być on w pełni regulowany mechanizmami rynkowej konkurencji, gdyż ochrona zdrowia realizuje cele społeczne, a mechanizm ten w takich przypadkach nierzadko zawodzi. Jednakże wyzwania, z jakimi obecnie musi się zmierzyć ochrona zdrowia na całym świecie, to wzrost populacji osób starszych, wzrost kosztów dotyczących technologii medycznych oraz wzrost oczekiwań pacjentów, z czym jest związane dążenie do efektywnej alokacji posiadanych środków finansowych oraz rzadkich zasobów w ochronie zdrowia. Placówki medyczne w Polsce mimo trudnej sytuacji gospodarczej podejmują działania inwestycyjne w rozwój infrastruktury, tj. budowę czy modernizację budynków, zakup nowoczesnego sprzętu diagnostycznego czy komputerowego. Działania te w większości są finansowane z funduszy unijnych. Kolejny pozy- 
tywny trend dotyczy dążenia przez placówki medyczne do uzyskania certyfikatów akredytacyjnych. Obecnie coraz większa liczba szpitali stara się uzyskać taki dokument, gdyż staje się on mocnym atutem w budowaniu korzystnego wizerunku placówki na rynku usług medycznych, nie tylko wobec swoich konkurentów, organów właścicielskich, lecz i pacjentów. Odbiór społeczny takiej placówki ze strony wszystkich interesariuszy jest bardzo pozytywny. Nie można jednak zapomnieć o tym, że to pacjent stanowi kluczowy element konkurencji, gdyż tak naprawdę to jego decyzja powinna wpływać na interakcje pomiędzy świadczeniodawcami, a w konsekwencji na decyzje podejmowane przez płatnika, co do np. wysokości finansowania danej placówki medycznej, w oparciu o uzyskane wyniki jakościowe, lecznicze czy finansowe, czego obecnie brak na polskim rynku usług zdrowotnych. Stąd tak ważne jest, aby został zainicjowany mechanizm zabiegania o pacjenta. Bardzo pozytywną rolę w dążeniu do usprawnienia funkcjonowania systemu opieki zdrowotnej upatruje się w realizacji rzetelnych badań konkurencyjności szpitali, które są potrzebne, gdyż pozwalają poznać swoją pozycję na rynku wobec konkurentów. Ponadto, pozwalają ocenić prestiż placówki, a pacjenci mogą na ich podstawie podjąć decyzję o tym, w którym szpitalu chcą być leczeni. Jednym z przykładów takich badań są organizowane w wielu krajach, w tym także i w Polsce, rankingi najlepszych placówek medycznych. Metoda porównywania się do najlepszych jest bardzo popularna w Stanach Zjednoczonych również w zakresie ochrony zdrowia, gdzie zastosowanie benchmarkingu może być skuteczne w stałym dążeniu do usprawnienia systemu zarządzania placówką medyczną. Aby benchmarking dobrze spełniał swoją rolę, musi uwzględniać specyfikę funkcjonowania placówki oraz zostać w odpowiedni sposób wdrożony. Pierwsze inicjatywy zastosowania tego procesu w jednostkach opieki zdrowotnej miały miejsce w Catholic Health Corporation oraz Voluntary Hospitals of America na terenie Stanów Zjednoczonych (Cygańska, 2013, s. 1; Kanownik, 2014, s. 563). Przykładem praktycznego zastosowania benchmarkingu jest raport opracowany przez światową firmę konsultingową Ernst \& Young na zlecenie American Hospital Association za lata 2009 i 2010, w którym dokonuje się porównań szpitali. Raport ten przedstawia takie obszary działalności szpitali, jak: ponoszone koszty i osiągane przychody, liczbę leczonych pacjentów (Results from 2009 \& 2010 Tax, 2013). Innym przykładem praktycznego zastosowania benchmarkingu jest raport opracowany przez Cristiano Codagnone i Francisco Lupianez-Villanueva na potrzeby Komisji Europejskiej w 2011 roku w zakresie przygotowania placówek medycznych Unii Europejskiej do realizacji świadczeń przy zastosowaniu technologii informatycznych, tzw. programy e-Zdrowie (Codagnone, Lupianez-Villanueva, 2011). Istotnym elementem w kształtowaniu konkuren- 
cyjności szpitali są realizowane przez wiele krajów na świecie rankingi szpitali, będące formą benchmarkingu, w ramach których stosuje się różnorodne mierniki oceny działalności placówek. W tabeli 1 przedstawiono projekty powszechnie uznanych analiz wydajności szpitali, realizowanych w formie rankingów $\mathrm{z}$ wykorzystaniem metody benchmarkingu. W realizację wyżej wymienionych projektów zaangażowało się wielu interesariuszy. Każdy z wymienionych rankingów opiera się na różnych zestawach kryteriów pomiaru, bazujących przede wszystkim na ocenie medycznej wydajności leczenia danego rodzaju schorzenia. Daje to pacjentowi możliwość otrzymania informacji, w którym szpitalu najlepiej będzie prowadzona terapia lecznicza, np. cukrzycy, chorób krążenia czy też leczenia chorób krwi i podjęcia decyzji, w której placówce warto podjąć terapię leczniczą. Ocena szpitala pod kątem jego konkurencyjności powinna dążyć do tego, by obiektywnie określić, czy hospitalizacja realizowana w danym szpitalu będzie przebiegać w warunkach o najwyższej jakości, czy też leczenie będzie prowadzone z pominięciem elementarnych zasad i ogólnie przyjętych standardów postępowania.

Tabela. 1. Wykaz rankingów szpitali metodą benchmarkingu

\begin{tabular}{|l|l|c|}
\hline \multicolumn{1}{|c|}{ Tytul projektu } & \multicolumn{1}{c|}{ Kraj } & $\begin{array}{c}\text { Rok } \\
\text { wdrożenia }\end{array}$ \\
\hline CHKS Top Hospitals Program & Wielka Brytania & 2001 \\
\hline Health Consumer Powerhouse & Kraje Unii Europejskiej & 2005 \\
\hline HealthInsight National Rankings for Hospitals & Stany Zjednoczone & 2004 \\
\hline Hospital Compare & Stany Zjednoczone & 2003 \\
\hline IASIST Top 20 Hospitals & Hiszpania & 2000 \\
\hline International Quality Indicator Program & Zasięg międzynarodowy & 1997 \\
\hline Leapfrog Group & Stany Zjednoczone & 2001 \\
\hline Michigan Manufacturing Technology Center (MMTC) & Stany Zjednoczone & 2005 \\
\hline $\begin{array}{l}\text { National Health Services (NHS) Choices Hospital } \\
\text { Scorecard }\end{array}$ & Wielka Brytania & 2008 \\
\hline Thomson \& Reuters Top 100 Hospitals & Stany Zjednoczone & 1994 \\
\hline US News \& World Report & Stany Zjednoczone & 1990 \\
\hline $\begin{array}{l}\text { World Health Organization Performance Assessment } \\
\text { Tool for Quality Improvement in Hospitals (PATH) }\end{array}$ & Zasięg międzynarodowy & 2004 \\
\hline
\end{tabular}

Źródło: Cercone, O’Brien, 2010, s. 5-6; Kanownik, 2014, s. 564. 
Czy benchmarking szpitali może wpłynąć na poprawę ich działalności? Okazuje się, że tak. Przykładem na to jest stosowany w Stanach Zjednoczonych ranking Hospital Compare, którego efektem było ustanowienie i rozpowszechnienie najlepszych praktyk w leczeniu takich chorób, jak: ostry zawał mięśnia sercowego, zastoinowa niewydolność serca i zapalenie płuc. Ponadto, ranking ten otworzył pacjentom drogę do tego, by stali się oni aktywnymi uczestnikami rynku i świadomie podejmowali decyzję o tym, w jakim szpitalu chcą być leczeni (Ibidem).

W oparciu o kryteria medyczne są realizowane też rankingi w innych krajach. Przykładowo, w Holandii ranking najlepszych szpitali według portalu internetowego AD.nl bazuje na 36 kryteriach, z czego 29 stanowią kryteria medyczne. Szpitale są zobowiązane do ujawniania danych medycznych w zakresie liczby zabiegów operacyjnych, liczby leczonych z daną jednostką chorobową, liczby reoperacji, rehospitalizacji, zakażeń medycznych czy czasu oczekiwania na przyjęcie do placówki. Francuski magazyn Le Point opiera swój ranking na następującym zestawie kryteriów oceny: aktywność (chodzi o liczbę wykonanych procedur w roku przez dany szpital, im większa aktywność, tym szpital jest lepiej oceniany), renoma szpitala, możliwość leczenie ambulatoryjnego poszczególnych jednostek chorobowych, wykorzystanie najlepszej techniki medycznej do realizacji określonych procedur medycznych, stopień specjalizacji szpitala, możliwość leczenia operacyjnego metodami laparoskopowymi, zdolność placówki do leczenia pacjentów najbardziej obciążonych w danej specyfice działalności oraz długość pobytu. Wszystkie wymienione kryteria odnoszą się do oceny jakości leczenia chorych z poszczególnymi jednostkami chorobowymi. Czyli i tutaj pacjent z rankingu ma możliwość dowiedzieć się, w którym szpitalu najlepiej będzie prowadzona terapia lecznicza, np. cukrzycy, białaczki czy chorób krążenia. I ostatni przykład - ranking szpitali publikowany przez U.S. News \& World Report, który analizuje dane z około 5000 ośrodków w Stanach Zjednoczonych i dokonuje oceny szpitali z podziałem na szpitale dla dorosłych i dzieci. Ranking ten, podobnie jak poprzednie, opiera się na ocenie kryteriów medycznych w 16 specjalnościach. Jeśli szpital jest uważany za jeden z najlepszych w co najmniej sześciu specjalnościach medycznych, to zyskuje prestiżowe miejsce w rankingu (Kanownik, 2013, s. 58-59).

Szpitale w Polsce nie uczestniczą w obowiązkowych publicznych systemach oceny, dających praktyczne wskazówki wszystkim interesariuszom systemu na temat ich słabych i mocnych stron. Instytucje regulujące i nadzorujące działalność szpitali, w większości dane o tych podmiotach zachowują dla siebie. Systematycznie natomiast pojawiają się informacje na temat zadłużenia szpitali. I tu rodzi się kolejna wątpliwość, czy taki ranking ma wartość praktyczną dla 
bezpośrednio zainteresowanych, czyli pacjentów. Jak wiadomo, fakt posiadania płynności finansowej przez podmioty lecznicze nie musi być dowodem prawidłowego zarządzania, może natomiast świadczyć o podejmowanych niepokojących oszczędnościach kosztem infrastruktury, wyposażenia w sprzęt itp. W systemach opieki zdrowotnej, w których finansowanie jest adekwatne do wykonywanych zadań, zła kondycja finansowa świadczyłaby raczej o niskiej frekwencji lub olbrzymich kosztach odszkodowań, co jest sygnałem dla pacjentów, że nie warto powierzać własnego zdrowia takim podmiotom.

Należy podkreślić, że wszelkie rankingi nie mogą zastąpić precyzyjnych i wiarygodnych, informacji o jakości pracy szpitali publikowanych m.in. przez Ministerstwo Zdrowia, Narodowy Fundusz Zdrowia czy organy właścicielskie szpitali. Zanim zaczną się one pojawiać regularnie, rankingi mogą spełniać funkcję doradczą, np. dla pacjentów. Krótko mówiąc, kiedy mamy świadomość pomiędzy czym wybieramy. W przypadku pacjenta ma to szczególne znaczenie, gdyż chodzi tu o jego zdrowie i życie. W Polsce teoretycznie prawo daje możliwość pacjentowi dokonać wyboru lekarza, czy też placówki, w której chce być leczony, jednak, aby mógł dokonać tego wyboru świadomie musi mieć dostęp do wiarygodnych informacji o placówkach medycznych.

Celem pracy jest przedstawienie kierunków praktycznego wykorzystania przez placówki medyczne benchmarkingu - metody pomiaru konkurencyjności, która może stanowić skuteczne narzędzie zarządcze, wspierające te placówki w ich dążeniu do uzyskania przewagi konkurencyjnej na rynku usług medycznym.

\section{Istota rankingu „Bezpieczny Szpital” w Polsce i rankingu „Bästa Sjukhuset” w Szwecji}

Obecnie opieka zdrowotna w wielu krajach podlega krytyce z uwagi na fakt, że nie spełnia ona wymagań, jakie są stawiane przed nią przez społeczeństwa, przede wszystkim w obszarach dotyczących niezadowalającej jakości świadczeń medycznych oraz ograniczonej dostępności do usług. Wyzwania, z jakimi obecnie musi się zmierzyć ochrona zdrowia na całym świecie, to wzrost populacji osób starszych, kosztów dotyczących technologii medycznych oraz oczekiwań pacjentów, z czym jest związane dążenie do efektywnej alokacji posiadanych środków finansowych oraz rzadkich zasobów materialnych i niematerialnych w ochronie zdrowia. W ocenie konkurencyjności szpitala przez poszczególnych interesariuszy mogą być pomocne publikowane i ogólnodostępne rankingi najlepszych placówek medycznych. W Polsce taką rolę pełni m.in. ogólnopolski 
ranking szpitali, realizowany wspólnie przez Centrum Monitorowania Jakości w Ochronie Zdrowia i dziennik „Rzeczpospolita”, pod nazwą „Bezpieczny Szpital". Ranking ten, opiera się na analizie ankiet nadesłanych dobrowolnie przez szpitale. Metodyka prowadzonych analiz pozostaje stała i nie wprowadza się radykalnych zmian co do treści i układu ankiet, po to, by wyniki z roku na rok były jak najbardziej porównywalne.

Poniżej zaprezentowano, jakie obszary podlegają analizie w wyżej wymienionym rankingu oraz jakie przypisano im wagi (http://www.cmj.org.pl/ranking/ wyniki_2014/wagi.php, dostęp: 08.03.2015):

- Obszar A - budynki, bezpieczeństwo eksploatacji budynków, WAGA: 70.

- Obszar B - zarządzanie majątkiem, WAGA: 60.

- Obszar C - zasilanie w media i instalacje, WAGA: 70.

- Obszar D - sale operacyjne i blok operacyjny, WAGA: 80.

- Obszar E - system sterylizacji, WAGA: 50.

- Obszar F - możliwość leczenia pacjenta w stanie nagłym, dostęp do diagnostyki, WAGA: 130.

- Obszar G - systemy informatyczne, WAGA: 40.

- Obszar H - zarządzanie, WAGA: 60.

- Obszar I - polityka lekowa, WAGA: 40.

- Obszar J - jakość usług, WAGA: 80.

- Obszar K - certyfikaty, WAGA: 100.

- Obszar L - komfort pobytu pacjenta, WAGA; 30.

- Obszar M - skargi i zdarzenia niepożądane, WAGA: 40.

- Obszar N - personel i jego kwalifikacje, WAGA: 90.

- Obszar O - finanse, WAGA: 60.

W połączonych obszarach można uzyskać następującą liczbę punktów:

- Zarządzanie - obszary: A, B, C, G, H, O - maksymalnie 360 pkt.

- Jakość opieki - obszary: J, K, L, M - maksymalnie 250 pkt.

- Opieka medyczna - obszary: D, E, F, I, N - maksymalnie 390 pkt.

Ogółem szpital może uzyskać maksymalnie 1000 pkt.

Powstaje zatem pytanie: jakie dane szczegółowe zostały przekazane przez szpitale w ramach oceny poszczególnych obszarów ich działalności i czy zastosowane kryteria oceny są adekwatne i wystarczające do tego, by możliwe było wysuwanie na podstawie przeprowadzonych analiz wniosków w pełni obiektywnych?

Obszary A, C, E, które najczęściej wypadają najlepiej w rankingu, dotyczą typowo zagadnień związanych z posiadaną przez szpital infrastrukturą i sprzę- 
tem diagnostycznym. Jak się okazuje, warto podjąć trud inwestowania, gdyż ma to przełożenie na pozyskanie wysokiej pozycji szpitala w rankingu, jednakże nietrudno zauważyć, że wśród szpitali wysuwających się na czoło rankingu znajdują się w większości placówki, które dokonały poważnych inwestycji budowlanych i technicznych, korzystając w dużej mierze $\mathrm{z}$ dofinansowania unijnego. Tego typu inwestycje wymagają sporych nakładów pieniężnych i sfinansowanie ich w ramach środków otrzymywanych z tytułu kontraktów, jakie szpital posiada z Narodowym Funduszem Zdrowia, jest praktycznie nierealne, zwłaszcza gdy placówka jest zadłużona.

Dla porównania spójrzmy, na podstawie jakich kryteriów następuje analiza potencjału konkurencyjnego szpitali w Szwecji, której system zdrowotny jest uważany za najlepszy na świecie. Wiele państw stawia go sobie za wzór godny naśladowania, a pacjenci niejednego kraju marzą o tym, by mieć możliwość korzystania z takiej opieki medycznej.

W Szwecji bardzo popularnym rankingiem analizującym konkurencyjność szpitali jest ranking organizowany przez uznany magazyn branżowy Dagens Medicin. Szpitale zostały, na potrzeby analizy rankingu, podzielone na trzy grupy: szpitale uniwersyteckie, szpitale średniej wielkości i szpitale małe.

Ranking powstał w oparciu o różnorodne kryteria. Każda z trzech wymienionych wcześniej grup szpitali jest oceniana m.in. według następujących kryteriów (załącznik 1 - „Bästa Sjukhuset”):

- Jakość medyczna.

- Analiza ankiet satysfakcji pacjentów.

- Dostępność do świadczeń.

- Finanse i posiadane zasoby.

- Warunki sanitarno-epidemiologiczne.

- Poziom opieki i leczenia związany z leczeniem chorób serca.

- Poziom opieki i leczenia związany z porodem.

- Poziom opieki i leczenia związany z leczeniem chorób ortopedycznych.

- Poziom opieki i leczenia związany z leczeniem urazów.

- Poziom opieki i leczenia związany z leczeniem chorób onkologicznych.

- Poziom opieki i leczenia związany z leczeniem chorób cukrzycy.

- Poziom opieki i leczenia związany z leczeniem chorób ginekologicznych.

Przyjęto, że szczególnym kryterium konkurencyjności dla szpitali średnich jest poziom opieki związany z porodem, a w przypadku szpitali małych szczególną uwagę przywiązuje się do leczenia ostrego, jako najważniejszego kryterium konkurencyjności dla szpitali zakwalifikowanych do tej grupy. Co 
ciekawe, kryteria ekonomiczne są tylko mierzone w przypadku szpitali uniwersyteckich. W każdej z wyżej wymienionych kategorii znajdują się bardzo precyzyjne pytania dotyczące np.: czasu oczekiwania na leczenie w zakresie określonego schorzenia, śmiertelności w przypadku określonych schorzeń, reoperacji, powikłań, rehospitalizacji, zaufania pacjenta do personelu medycznego, stopnia uczestnictwa pacjenta w terapii leczniczej, a w przypadku kosztów porównanie polega na określeniu kosztów, jakie ponosi szpital w związku z realizacją określonej grupy JGP $(\mathrm{DRG})^{2}$, np. pęcherzyka żółciowego.

Jak widać z powyższego, w szwedzkich szpitalach przyjęta i realizowana zasada zarządzania kosztami poprzez jakość, zarówno w aspekcie makro, jak i mikro prowadzi do korzyści przede wszystkim dla pacjenta, ale też zarówno dla pracownika, jak i dla szpitala. Pacjent odczuwa w wyniku tych działań poprawę w postaci lepiej funkcjonującego systemu udzielania świadczeń, systematyczne poprawianie jakości i bezpieczeństwa opieki, szybkie dostosowywanie się szpitali do potrzeb i oczekiwań pacjenta, przestrzeganie praw pacjenta. Personel medyczny z kolei odczuwa poprawę organizacji pracy, uporządkowanie zakresu obowiązków, uprawnień i odpowiedzialności pracowników, czy też wzrost zaangażowania pracowników w proces dążenia do poprawy jakości świadczonych usług medycznych. Szpital poprzez tego typu działania osiagga racjonalizację kosztów, podniesienie prestiżu placówki na zewnątrz, wzrost zaufania interesariuszy szpitala, stabilizację kadry medycznej.

Bycie efektywnym szpitalem wymaga analizowania informacji na temat nakładów, wydajności procesów oraz rezultatów, które są uzyskiwane. Zebranie informacji i zrozumienie, gdzie znajduje się szpital na tle rynku, może pomóc wskazać kierunek strategicznych inicjatyw, zidentyfikować potencjał rozwojowy i obrać realne cele. Proces systematycznego porównywania własnej jednostki z innymi oraz porównywania ze sobą różnych komórek organizacyjnych szpitala, aby ustalić, jaki jest jego stan obecny i czy potrzebna jest jakaś zmiana, pozwala na błyskawiczną interwencję w sytuacjach niepokojących.

2 DRG (Diagnosis-Related Group) - sposób rozliczania usług zdrowotnych przez płatnika (w Polsce Narodowy Fundusz Zdrowia). Ideą tego rozwiązania jest stworzenie w miarę prostych i łatwych w stosowaniu metod kwalifikowania (już po wykonaniu) danego świadczenia do pewnej grupy ze ściśle zdefiniowanej listy w celu rozliczenia usługi przed płatnikiem. Praktyczna konstrukcja tego systemu wynika z obserwacji, że pewne grupy pacjentów, często znacznie różniących się, w zasadzie wymagają dość podobnego postępowania. Jednocześnie, ta sama choroba u pacjentów różniących się wiekiem i wspólistniejącymi problemami wymaga często całkiem innego podejścia. Kwalifikację do grupy wykonuje się albo na podstawie rozpoznania definiowanego międzynarodową klasyfikacją chorób i problemów zdrowotnych ICD-10 (dotyczy głównie leczenia niezabiegowego), albo procedurą leczniczą, wymienioną w liście JGP identyfikowaną kodem klasyfikacji ICD-9. 
Wprowadzenie nawet najmniejszych zmian może w znaczny sposób usprawnić efektywność jednostki, by uzyskać większy przychód przy tym samym (bądź zredukowanym) nakładzie zasobów i środków.

\section{Proponowane kierunki pomiaru konkurencyjności szpitali powiatowych - wyniki badań własnych}

Pomiar konkurencyjności szpitali powiatowych powinien dotyczyć kluczowych determinant (czynników) konkurencyjności. Stąd też zrealizowane badania empiryczne, mają na celu skonstruowanie takich mierników pomiaru konkurencyjności, aby można było dokonywać pomiaru w sposób szybki, relatywnie tani i nieobciążający dodatkową pracą pracowników szpitali, którzy będą odpowiedzialni za zbieranie danych. Mierniki mają być zrozumiałe dla wszystkich odbiorców, do których trafi raport.

Przypomnijmy, że celem pracy jest przedstawienie kierunków praktycznego wykorzystania przez placówki medyczne benchmarkingu - metody pomiaru konkurencyjności, która może stanowić skuteczne narzędzie zarządcze, wspierające te placówki $\mathrm{w}$ ich dążeniu do uzyskania przewagi konkurencyjnej na rynku usług medycznym. W związku z powyższym, przeprowadzono badanie empiryczne, którego efektem jest przedstawienie rekomendacji służących do opracowania w dalszych badaniach naukowych modelu pomiaru przydatnego dla stymulowania efektywnego działania szpitali w ich dążeniu do budowania wartości dla pacjentów w długim okresie, uwzględniając ograniczenia wynikające z oczekiwań i wymagań ze strony kluczowych interesariuszy.

\subsection{Koncepcja metodyczna badania}

Badanie przygotowano w ramach własnego projektu badawczego pt. „Mierniki i metody pomiaru konkurencyjności szpitali powiatowych - instrumenty wspierające rozwój konkurencji w publicznym i niepublicznym sektorze ochrony zdrowia z punktu widzenia interesariuszy", finansowanego w ramach badań naukowych i prac rozwojowych młodych naukowców Szkoły Głównej Handlowej w 2014 roku. Badanie było realizowane osobiście przez autorkę. Z uwagi na ograniczenia kadrowe, finansowe oraz czasowe pole badawcze ograniczono do szpitali powiatowych. Próba badawcza była próbą celową. Wywiady prowadzono od 1 lipca do 10 października 2014 roku. Łącznie zrealizowano 39 wywiadów. Badania jakościowe, czyli Indywidualne Wywiady Pogłębione (Individual In-Depth Interviews - IDI), zostały przeprowadzone przy wykorzystaniu kwestionariusza pytań, z którymi osoby badane zapoznały się wcze- 
śniej przed przeprowadzeniem badania. Przebieg badania był rejestrowany za pomocą rejestratora rozmów (dyktafon).

Przed przeprowadzeniem wywiadu każdemu z wybranych rozmówców przedstawiono kwestionariusz pytań badawczych wraz z przyjętą na potrzeby prowadzonego badania naukowego definicją konkurencji i konkurencyjności. Dobór respondentów do wywiadów był celowy z uwagi na istotę badanego problemu - badanie miało charakter sondażowy. Respondenci przedmiotowego badania reprezentowali następujące funkcje: dyrektorzy, zastępcy dyrektora naczelnego, prezesi, starostowie, dyrektorzy lub zastępcy dyrektora określonych wydziałów bądź departamentów, urzędów, które reprezentowali. Dużą zaletą był fakt, iż respondenci pełnili wcześniej inne funkcje, związane z ochroną zdrowia, np. wykonywali obowiązki dyrektora szpitala, pracowali w NFZ, są lekarzami, co wniosło dodatkową wartość dodaną do badania z uwagi na szerokie doświadczenie praktyczne osób biorących udział w wywiadach.

Badanie przeprowadzono $\mathrm{w}$ następujących instytucjach państwowych: Ministerstwo Zdrowia - Departament Ubezpieczenia Zdrowotnego, Centrala Narodowego Funduszu Zdrowia, Dolnośląski Oddział Wojewódzki Narodowego Funduszu Zdrowia, Kujawsko-Pomorski Oddział Wojewódzki Narodowego Funduszu Zdrowia, Małopolski Oddział Wojewódzki Narodowego Funduszu Zdrowia, Mazowiecki Oddział Wojewódzki Narodowego Funduszu Zdrowia, Warmińsko-Mazurski Oddział Wojewódzki Narodowego Funduszu Zdrowia, Dolnośląski Urząd Wojewódzki we Wrocławiu - Wydział Polityki Społecznej, Kujawsko-Pomorski Urząd Wojewódzki w Bydgoszczy - Wydział Zdrowia, Lubuski Urząd Wojewódzki w Gorzowie Wielkopolskim - Wydział Zdrowia, Podkarpacki Urząd Wojewódzki w Rzeszowie - Wydział Polityki Społecznej, Warmińsko-Mazurski Urząd Wojewódzki w Olsztynie - Wydział Zdrowia, Urząd Ochrony Konkurencji i Konsumentów w Warszawie - Departament Analiz Rynku.

Badanie przeprowadzono w następujących powiatach: buskim, jarocińskim, kluczborskim, opolskim, ostródzkim, otwockim, piskim, prudnickim, rawickim, sochaczewskim, toruńskim, wolsztyńskim i tczewskim.

Badanie przeprowadzono w szpitalach powiatowych:

- samodzielne publiczne zakłady opieki zdrowotnej: Zespół Opieki Zdrowotnej w Busku-Zdroju, Samodzielny Publiczny Zakład Opieki Zdrowotnej Szpital Powiatowy w Piszu, Zespół Opieki Zdrowotnej „Szpitala Powiatowego" w Sochaczewie, Samodzielny Publiczny Zakład Opieki Zdrowotnej w Wolsztynie;

- szpitale powiatowe działające w formie spółki z ograniczoną odpowiedzialnością: Szpital Powiatowy Sp. z o.o. w Chełmży, „Szpital Powiatowy w Jaro- 
cinie" Spółka z o.o., Powiatowe Centrum Zdrowia Sp. z o.o. w Otwocku, Szpital Powiatowy w Rawiczu Sp. z o.o.;

- szpitale powiatowe działające $\mathrm{w}$ formie spółki akcyjnej: Powiatowe Centrum Zdrowia S.A. w Kluczborku, Szpital Św. Rocha w Ozimku EMC Instytut Medyczny S.A., Powiatowy Zespół Opieki Zdrowotnej w Ostródzie S.A., Prudnickie Centrum Medyczne S.A. w Prudniku, Szpitale Tczewskie S.A.

Podczas analizy otrzymanych danych jakościowych z przeprowadzonych wywiadów dokonano podziału uzyskanych wyników na grupy, tzn. dokonano oceny opinii interesariuszy, do których zaliczono: regulatorów i decydentów systemu zdrowotnego. Do tej grupie zaliczono: Ministerstwo Zdrowia oraz Urzędy Wojewódzkie. Narodowy Fundusz Zdrowia reprezentuje rolę płatnika, czyli nabywcy usług zdrowotnych, natomiast przedstawiciele starostw powiatowych, to decydenci lokalni, a szpitale powiatowe zostały zaliczone do grupy interesariuszy jako dostarczyciele świadczeń usług medycznych. Ponadto, dokonano podziału opinii na szpitale, które działają w ramach określonej formy prawnej, czyli: samodzielnych publicznych zakładów opieki zdrowotnej, szpitali powiatowych działających w formie spółki z ograniczoną odpowiedzialnością, szpitali powiatowych działających w formie spółki akcyjnej.

W przypadku szpitali powiatowych dokonano wyboru próby celowej w oparciu o następujące kryteria:

- szpitale o I stopniu referencyjności, tj. szpitale udzielające świadczeń zdrowotnych w czterech podstawowych specjalnościach medycznych: chorób wewnętrznych, chirurgii ogólnej, położnictwa i ginekologii, pediatrii oraz anestezjologii i intensywnej terapii;

- ze względu na zasięg terytorialny wyodrębniono szpitale powiatowe (lub miejskie w miastach na prawach powiatu);

- ze względu na formę organizacyjno-prawną, badanie obejmowało trzy rodzaje szpitali powiatowych:

a) szpital powiatowy działający $\mathrm{w}$ formie samodzielnego publicznego zespołu opieki zdrowotnej,

b) szpital powiatowy działający w formie spółki prawa handlowego, w którym udziały większościowe posiada podmiot tworzący, w tym przypadku jest to powiat,

c) szpital powiatowy działający w formie spółki prawa handlowego, którego udziały należą wyłącznie do prywatnych inwestorów.

Realizacja Indywidualnych Wywiadów Pogłębionych (IDI) została przeprowadzona według schematu przedstawionego na rysunku 1. 
Rysunek 1. Schemat realizacji Indywidualnych Wywiadów Pogłębionych (IDI)

\section{ARANŻACJA WYWIADU}

Nawiązanie kontaktu listownego, e-mailowego z respondentem w celu uzyskania zgody na przeprowadzenie wywiadu - przedstawienie celu badania oraz kwestionariusza wywiadu.

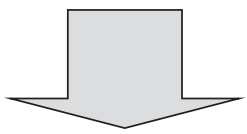

\section{USTALENIE TERMINU BADANIA}

Ustalenie z respondentem terminu spotkania, w którym mógłby być przeprowadzony wywiad pogłębiony (IDI), dostarczenie dodatkowych informacji dotyczących przebiegu badania oraz udzielanie odpowiedzi na dodatkowe pytania respondentów w tym względzie.

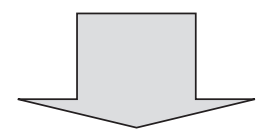

\section{REALIZACJA BADANIA}

Wywiady zostały przeprowadzone osobiście przez doktorantkę, która oprócz merytorycznego przygotowania badawczego posiada szeroką wiedzę merytoryczną i doświadczenie zawodowe z zakresu ochrony zdrowia.

Było to dodatkowym atutem podczas realizacji badania i spotkało się z dużą aprobatą rozmówców, gdyż mieli gwarancję, że ich wypowiedzi nie zostaną opacznie zrozumiane i zinterpretowane.

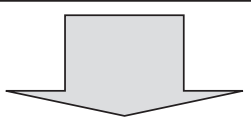

\section{UTRWALENIE INFORMACJI POZYSKANYCH W TRAKCIE BADANIA}

Wywiady zostały nagrane dyktafonem i zapisane w formacie pliku mp3.

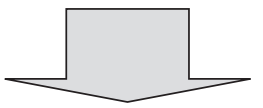

\section{TRANSKRYPCJA WYWIADU}

Aby możliwe było dokonanie analizy jakościowej uzyskanego materiału, dokonano transkrypcji nagrań z przeprowadzonych wywiadów.

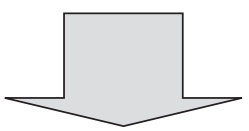

\section{ANALIZA JAKOŚCIOWA WYWIADU}

Zebrany podczas wywiadów materiał źródłowy został poddany analizie jakościowej nakierowanej na poszukiwanie prawidłowości. Analiza jakościowa została przeprowadzona w trzech etapach:

(1) analiza jakości materiału, (2) analiza zawartości materiału, (3) formułowanie wniosków i rekomendacji.

Źródło: opracowanie własne na podstawie raportu z realizacji badania pogłębionego „Diagnoza potrzeb uczelni, studentów i absolwentów w zakresie budowania trwałych relacji uczelnia - student - absolwent opartych na wzajemnej wymianie wiedzy i doświadczenia", zrealizowanego w ramach projektu prowadzonego przez Collegium Mazovia - Innowacyjna Szkoła Wyższa w 2013 roku, s. 104. 


\section{Pytania dotyczące tej części bloku badawczego w zakresie pomiaru konku- rencyjności szpitali powiatowych brzmiały:}

1. Jakie obecnie mierniki konkurencyjności bądź metody pomiaru są wykorzystywane przez Pania/Pana do oceny i porównania konkurencyjności szpitali powiatowych między sobą i dlaczego?

2. Czy według Pani/Pana mierniki i metody pomiaru powinny być:

a) jednakowe dla szpitali publicznych - SPZOZ, szpitali samorządowych i szpitali prywatnych?

b) powinny się różnić (proszę o uzasadnienie odpowiedzi)?

3. Według Pani/Pana opinii, jakie korzyści bądź zagrożenia mogą wynikać z systematycznego dokonywanego pomiaru konkurencyjności szpitali powiatowych?

W przypadku pytania pierwszego (tego bloku badawczego), respondenci z grupy Ministerstwa Zdrowia i Urzędu Wojewódzkiego wyrazili opinię, że nie posiadają narzuconych metod lub mierników pomiaru konkurencyjności szpitali powiatowych. Obecnie nie mają one też ustawowego obowiązku oceny tych podmiotów. W większości oceny szpitali opierają się na szerokiej ocenie działalności finansowej szpitala, badaniu jego zadłużenia itp. Jeden z respondentów wskazał na ocenę dostępności do świadczeń i ich jakość, natomiast inny badany wskazał na dokonywanie analizy, ale raczej o charakterze systemowym, które mają służyć wypracowaniu określonych rozwiązań, dotyczących np. poszczególnych segmentów rynku. W większości rozmówcy wskazują na brak istnienia wzorcowego modelu pomiaru konkurencyjności, co zapewne byłoby niezmiernie wskazane i jest oczekiwane przez regulatorów systemu zdrowotnego. Rozmówcy zauważyli, że brak takiego narzędzia wynika z braku określenia wzorcowej definicji modelu konkurencyjności w polskiej służbie zdrowia.

Oto wypowiedź jednego z respondentów:

tęsknimy za takim narzędziem, które by nam dawało możliwość analitycznego podejścia do zagadnienia [...], ale $w$ tej kwestii musielibyśmy na nowo zdefiniować zagadnienie konkurencyjności [...], ponieważ te kategorie konkurencyjności, które sa wtaściwe wolnemu rynkowi, nie zawsze sa trafne dla rynku zdrowotnego. Czyli należatoby się zastanowić nad teoretycznym modelem konkurencyjności w ochronie zdrowia, jak powinien on wzorcowo wygladać $i$ wtedy dopiero próbować przybliżyć się do zobiektywizowania tego problemu. Wówczas $z$ korzyścia taka analize można by byto prowadzić. Na dzień dzisiejszy wydaje mi się, że brakuje nam analitycznego i racjonalnego podejścia do problemu. 
Z kolei rozmówca z Urzędu Ochrony Konkurencji i Konsumentów poinformował, iż ta instytucja nie dokonuje porównań konkurencyjności między szpitalami. Jednak respondent ten wskazał, iż ta problematyka dotycząca mierników konkurencyjności jest bardzo ważna; chodzi o to, aby oceny konkurencyjności były adekwatne do rzeczywistości i by kryteria oceny były logiczne, racjonalne i przemyślane. Przy tym zwrócił też uwagę na fakt, by wybrane mierniki oceny nie straciły swojej wartości informacyjnej, czyli gdy coś staje się benchmarkiem, nie stało się w pewnym sensie paradoksem oceny samej w sobie i w ostateczności nie służyło szpitalom, zamiast pacjentom.

Rozmówcy z grupy reprezentującej płatnika, czyli Narodowy Fundusz Zdrowia, wskazywali, że istnieją odgórne przepisy ustawowe względem wszystkich świadczeniodawców, odnoszące się do realizowanych procedur, np. dotyczących przyjęć, kolejek oczekujących itd. Przepisy te również odnoszą się do konkursu ofert na świadczenia medyczne, gdzie są zawarte określone kryteria oceny dla poszczególnych rodzajów umów, za które świadczeniodawcy otrzymują odpowiednią punktację. W zależności od rankingu oceny wszystkich oferentów otrzymują określone fundusze na realizację świadczeń. Oceny, które dokonuje płatnik, opierają się na przepisach ustawowych. Każdy wojewódzki oddział posiada własną wypracowaną metodę oceny i porównań, opracowaną przez własnych pracowników.

Jeden z respondentów zauważył, że ocena szpitali pod kątem bazy łóżkowej obecnie nie jest już wykonywana, gdyż bardziej istotne jest porównanie szpitali z perspektywy ich efektywności. Chodzi o to, co potrafi wykonać personel medyczny i jakie uzyskuje efekty leczenia, ponieważ bardzo istotne jest, by pacjent był hospitalizowany w szpitalu tylko wtedy, gdy jest taka konieczność. Unika się w ten sposób wykonywania zbędnych hospitalizacji, a leczenie mniej obciążających przypadków następuje podczas leczenia ambulatoryjnego.

Oto przedstawione według rozmówców kryteria oceny szpitali, jakie stosuje płatnik: ciągłość świadczeń, kompleksowość świadczeń, jakość świadczeń potwierdzona certyfikatem ISO i certyfikatem akredytacyjnym, dostępność do świadczeń, struktura wykonywanych świadczeń, tryby przyjęcia (czy są to przyjęcia planowe, których leczenie zazwyczaj jest mniej kosztochłonne czy przyjęcia bardziej kosztochłonne, czyli tzw. ostre, nagłe, ratujące życie), struktura przychodów szpitali.

Starostwa powiatowe, na terenie których działają szpitale powiatowe w formie SPZOZ, w tej grupie interesariuszy, respondenci wskazali, że nie dysponują bazą danych o szpitalach w poszczególnych powiatach, dlatego porównanie działalności szpitali między sobą jest właściwie niemożliwe. Zazwyczaj porów- 
nanie, jeżeli już jest dokonywane to przez Związek Powiatów Polskich, a wtedy bardziej jest nakierowane na wyniki finansowe placówek medycznych.

Jedna osoba wskazała, że śledzi ogólnopolskie rankingi oceny szpitali, np. „Bezpieczny Szpital”, co pozwala w pewnym sensie ocenić swoją placówkę - w którym miejscu się znajduje i co ewentualnie powinno być w niej wykonane. Brany jest też pod uwagę stan epidemiologiczny powiatu. Jeden z rozmówców stwierdzit, iż trudno jest pozyskać informację od dyrektorów szpitali z innych powiatów. Inny respondent wskazał natomiast, że zwraca też uwagę na zakres świadczeń realizowanych w swoim szpitalu w porównaniu do innych placówek, po to, by baza oferowanych usług dla mieszkańców powiatu była dość szeroka.

Z punktu widzenia szpitali powiatowych SPZOZ, jeden z rozmówców wskazał, że w jego przypadku brana jest pod uwagę migracja pacjentów za daną usługą medyczną do innych szpitali, oferta usługowa innych szpitali. Respondent chciał w ten sposób poznać przyczyny tego, dlaczego pacjenci wybierają inny szpital, a nie jego. Inny z respondentów wskazał na obserwację pod kątem, jak konkurencja zarządza kosztami, czy te koszty są większe niż w jego szpitalu. Ważny jest element rozwojowy, jakościowy i kosztowy. Inny z badanych stwierdzit, iż obserwuje wskaźniki zachorowalności na terenie, w którym działa szpital, by w ten sposób określić zapotrzebowanie na określone procedury medyczne, które mógłby świadczyć ten szpital. W przypadku swojego szpitala zarządzający oceniają, także pod kątem konkurentów, jeśli to możliwe: stopień realizacji kontraktu od płatnika oraz czy jest on wystarczający w stosunku do zapotrzebowania, przychody i koszty, liczbę hospitalizacji, liczbę rehospitalizacji, przestrzeganie procedur jakościowych określonych standardami akredytacyjnymi, obsługę pacjenta (analiza ankiet satysfakcji pacjenta), wyposażenie w aparaturę i sprzęt medyczny, efektywność postępowania terapeutyczno-leczniczego (skrócenie czasu pobytu pacjenta w szpitalu, zadowolenie pacjenta, szybkość powrotu do zdrowia w okresie po hospitalizacji, w okresie rekonwalescencji).

Starostowie, na których terenie działają szpitale powiatowe o formie prawnej Sp. z o.o., z większościowym udziałem podmiotu tworzącego, za kryteria oceny wykorzystywane do porównywania szpitali powiatowych, wskazali: liczbę leczonych pacjentów, efektywność kosztową, przychody, wskaźniki finansowe. Najczęściej oceny są dokonywane za pośrednictwem konwentu starostów, przy czym są to raczej analizy finansowe, a nie jakościowe. Jakościowe oceny wykonuje płatnik, który na spotkaniach z nami, jak twierdzi jeden z respondentów, przedstawia je nam, ale:

często po to, żeby coś na nas wymusić. Wiadomo, że te dane sa przygotowane po to, żeby pomóc ptatnikowi, a nie nam. 
Dwóch rozmówców z tej grupy wskazało, że nie ma żadnych ocen szpitali. Jeden z nich stwierdzit, że jest to niepotrzebne, gdyż szpitale powiatowe nie konkurują ze sobą. Natomiast drugi z tych rozmówców stwierdził, że taka ocena byłaby wskazana; choćby po to, by możliwa była racjonalna ocena potrzeb zdrowotnych na danym obszarze.

Szpitale powiatowe działające $w$ formie prawnej Sp. z o.o., z większościowym udziałem podmiotu tworzącego - w tej grupie respondentów jedna osoba wskazała, że obecnie trwają prace nad opracowaniem kryteriów oceny grupy szpitali powiatowych dla danego regionu. W wyniku porozumienia szpitale te będą udostępniały pewne dane, aby takie oceny porównawcze przygotowywać, które dalej będą wykorzystywane na użytek tych szpitali. Będą to jednak przede wszystkim oceny opierające się na porównaniu aspektów ekonomicznych działalności szpitali. Dwóch respondentów wskazało, że korzysta z benchmarkingu prowadzonego przez prywatne firmy usługowe, przy czym dane, jakie są tu zbierane, mają typowy charakter i sprowadzają się raczej do typowych wskaźników ekonomicznych. Do oceny własnego szpitala i poszczególnych oddziałów czy poradni ci sami respondenci również wykorzystują analizę ekonomiczną. Jeden rozmówca wskazał, że benchmark niestety nie pomaga mu w podejmowaniu decyzji zarządczych, ponieważ obecny rynek zdrowotny, z uwagi na swoje ograniczenia, nie pozwala mu na podejmowanie swobodnych decyzji zarządczych. Kolejny z respondentów wskazał, iż w aspekcie jakości usług realizowanych w swoim szpitalu ocenia liczbę skarg, analizuje ankiety satysfakcji pacjenta, prowadzi wyrywkowe rozmowy z pacjentami i te aspekty stara się porównywać do danych historycznych, co pozwala mu ocenić, jak oraz czy jakość usług poprawia się. Ważnym kryterium jest także renoma szpitala i uzyskany efekt terapeutyczny.

Starostwie, na terenie których działają szpitale powiatowe o formie prawnej S.A., z większościowym udziałem podmiotu tworzącego. Jeden ze szpitali jest szpitalem mającym w 100\% inwestora prywatnego. Jeden z respondentów wyraził opinię, że dokonuje oceny potencjału kadrowego, oferty usługowej oraz zabezpieczenia sprzętowego, gdyż szpital, który posiada te trzy elementy jest w stanie najbardziej zagrozić mojej placówce. Kolejny z respondentów wskazał, iż korzystał z usług prywatnej firmy benchmarkingowej, która dokonywała oceny szpitali, gdzie jego szpital był usytuowany na tle województwa, kraju, a także w aspekcie pewnych usług. Jednak ta ocena mogła być niezbyt wiarygodna, gdyż były porównywane ze sobą różne szpitale i pojawiły się wątpliwości odnoszące się do adekwatności stosowanych mierników oceny. Dla tego rozmówcy ważna jest kwestia ekonomiczna, ale także migracja pacjentów. Kolejny z respondentów również wskazał, iż najbardziej istotne w jego oce- 
nie szpitala są zagadnienia ekonomiczne. Dwóch respondentów nie dokonuje oceny szpitali. Jeden $z$ nich uzasadniat, iż nie jest to dla nich istotne. Natomiast drugi wskazywał, że z uwagi na fakt, iż nie posiada udziałów większościowych $\mathrm{w}$ żadnym szpitalu powiatowym nie dokonuje takiej oceny szpitali.

Szpitale powiatowe działające $w$ formie prawnej S.A., z większościowym udziałem podmiotu tworzącego. Jeden ze szpitali jest szpitalem, mającym w 100\% inwestora prywatnego. W tej grupie dwóch respondentów wskazało, iż ocenia szpitale pod kątem zasobów technicznych i kadrowych oraz oferty usługowej, skierowanej do pacjentów. W przypadku swojego szpitala oceniają przede wszystkim koszty, liczbę przyjętych pacjentów i realizację kontraktu. Dwóch rozmówców korzysta z usług zewnętrznej firmy benchmarkingowej, jednakże na własne potrzeby dokonuje oceny migracji pacjentów, realizacji kontraktu, analizy skarg, a drugi rozmówca ocenia koszty, realizację kontraktu i stopień realizacji przez poszczególne oddziały przydzielonego budżetu. Kolejny rozmówca wskazał, że nie dokonuje porównań z innymi szpitalami. Nie są one wykonywalne, ponieważ inne placówki traktują te informacje jako dane handlowe, dlatego najczęściej korzysta z dostępnych publikacji o działalności innych placówek, gdzie może uzyskać pewne interesujące go informacje. Do oceny własnej placówki wykorzystuje dane ściśle ekonomiczne, stopień realizacji budżetu przez poszczególne komórki szpitala, a pod kątem jakościowym dokonuje pomiaru wskaźników określonych standardami akredytacyjnymi, które porównuje z danymi historycznymi. Na tej podstawie wysuwa określone wnioski i ocenia działalność szpitala.

W przypadku pytania drugiego (tego bloku badawczego), respondenci z grupy Ministerstwa Zdrowia i Urzędu Wojewódzkiego opowiedzieli się za jednolitym sposobem pomiaru konkurencyjności w szpitalach powiatowych. Przy czym dwóch z nich zaznaczyło, że kwestia jednolitego pomiaru jest ważna przede wszystkim dla pacjentów, ponieważ pacjent jest najbardziej zainteresowany efektem leczenia, a nie rodzajem szpitala, do którego trafił na terapię. Natomiast z punktu widzenia województwa i powiatu, pomiar na pewno powinien uwzględniać pewne aspekty, wpływające na zróżnicowanie działalności tych szpitali, co powinno znaleźć odzwierciedlenie w odpowiednio dobranych kryteriach pomiaru konkurencyjności.

Rozmówca Urzędu Ochrony Konkurencji i Konsumentów wskazał na fakt, że pomiar powinien być dostosowany do rodzaju interesariuszy, którzy go dokonują, ponieważ jednak każda grupa dąży do oceny szpitali w zależności od stopnia wzajemnych relacji na rynku.

Narodowy Fundusz Zdrowia - w tej grupie respondenci wyrazili opinię, że mierniki pomiaru powinny być równe i takie same dla szpitali, niezależnie od 
tego, jaką formę prawną posiadają. Dwóch rozmówców stwierdziło, że wskazane jest, aby tego typu oceny różniły się z punktu widzenia tzw. referencyjności. Jeden z nich uzasadniał swoją opinię następująco:

z cała pewnościa należy inaczej spoglądać na szpitale kliniczne, inaczej na szpitale wysokospecjalistyczne, inaczej na szpitale, które w pewnym sensie sq szpitalami monopolistycznymi, na przyktad zajmującymi się tylko okulistyka, a inaczej na te podstawowe. I to jest jedyna różnica i jedyna kategoria, w której chcielibyśmy inaczej spogladać na poszczególne grupy, ale tylko dlatego, że sa to szpitale, które spetniaja zupetnie inna funkcję.

Starostwie, na których terenie działają szpitale powiatowe w formie SPZOZ - w tej grupie trzech rozmówców wskazało, że pomiar konkurencyjności szpitali powiatowych powinien być jednakowy i opierać się na jednakowych kryteriach oceny, niezależnie od formy prawnej szpitala. Jeden z respondentów wskazał, że pomiar konkurencyjności powinien opierać się na odmiennych kryteriach oceny, uwzględniających odmienne uwarunkowania, w których działają poszczególne szpitale, czyli: demografia, infrastruktura, zasoby itd., a w ślad za taką oceną powinno iść odpowiednie finansowanie z Narodowego Funduszu Zdrowia.

Z punktu widzenia szpitali powiatowych SPZOZ, dwóch respondentów zdecydowanie wyraziło opinię, że pomiar oceny powinien być jednakowy. Trzeci rozmówca wskazał, że forma prawna nie ma tu żadnego znaczenia i nie powinna wpływać na różnicowanie szpitali, natomiast pomiar powinien uwzględniać i być jednolity dla szpitali o podobnym potencjale, tzn. tak samo powinniśmy oceniać szpitale należące do poszczególnych grup, np. jednoimienne, wieloprofilowe, gdyż jest inna skala trudności w prowadzeniu tego typu szpitali. Następny rozmówca wskazał na fakt, że pomiar powinien być jednakowy dla szpitali publicznych niezależnie od formy prawnej. Natomiast w tej grupie szpitali nie powinno się ujmować szpitali prywatnych z uwagi na aspekt przychodowy. W tym przypadku różnica pomiędzy szpitalami jest znaczna, gdyż prywatna placówka może pozyskiwać środki finansowe w nieco odmienny sposób niż szpital publiczny, w pozostałych kwestiach pomiar powinien być jednakowy.

Starostwie, na terenie których dziatają szpitale powiatowe o formie prawnej Sp. z o.o., z większościowym udziałem podmiotu tworzącego, w tej grupie rozmówców jeden respondent zdecydowanie wyraził opinię, że ocena konkurencyjności szpitali powiatowych powinna być taka sama. Dwóch respondentów wskazało, że w przypadku publicznych szpitali niezależnie od formy prawnej mierniki oceny powinny być jednakowe, natomiast szpitale prywatne powinny być porównywane oddzielnie według innych mierników. Następny rozmówca wskazał, że mierniki oceny konkurencyjności szpitali powiatowych powinny 
się różnić, ponieważ z uwagi na brak stabilizacji gospodarczej oraz polskiego systemu zdrowotnego, gdzie nie dopracowano się nadal gruntownych filarów regulacyjnych, otrzymane wyniki z takiej oceny mogłyby nie być adekwatne do rzeczywistości i mogłyby być zrozumiane opacznie przez odbiorców.

Szpitale powiatowe działające $w$ formie prawnej Sp. z o.o., z większościowym udziałem podmiotu tworzącego, w tej grupie rozmówców jeden z nich wskazał, że mierniki pomiaru konkurencyjności powinny być jednakowe dla wszystkich szpitali. Trzej pozostali respondenci wskazali, że metody pomiaru powinny być jednakowe. Przy czym jeden z nich stwierdził, że raczej pomiar powinien obejmować poszczególne grupy szpitali, np. powiatowe, wojewódzkie, specjalistyczne. Kolejny zaznaczył, że różnica w pomiarze powinna dotyczyć podatku i dzierżawy, bo one nie występują w SPZOZ. W podobnym tonie wypowiedział się trzeci respondent, który uznał, że różnica w pomiarze powinna uwzględniać sposób traktowania amortyzacji, co uzasadniał w następujący sposób:

$w$ spótce amortyzacja, oczywiście $w$ dużym uproszczeniu, bo pomijajac różnice między amortyzacja bilansowa i podatkowa, jest brana pod uwage przy ustalaniu wyniku, a jednocześnie jest generatorem wolnych środków i plynności w szpitalu. W SPZOZ jako jednostka finansów publicznych amortyzacja nie ma takiego znaczenia.

Starostwie, na terenie których działają szpitale powiatowe o formie prawnej S.A., z większościowym udziałem podmiotu tworzącego. Jeden ze szpitali jest szpitalem, mającym w 100\% inwestora prywatnego. W tej grupie respondentów dwie osoby zdecydowanie wskazały, że pomiar konkurencyjności powinien być dokonywany jednakowymi metodami. Dwóch wskazało, że metody pomiaru powinny się różnić. Jeden z badanych wyraził opinię, że część mierników powinna dotyczyć szpitali publicznych, część prywatnych, a pozostałe powinny być jednakowe dla wszystkich. Oto uzasadnienie tej opinii:

uważam, że powinny być wypracowane obiektywne mierniki i metody pomiaru, na przykład przez Ministerstwo Zdrowia, które pozwolitoby porównać szpitale między soba. Częś́ z tych mierników dotyczytaby na przyktad tylko SPZOZ, część z nich szpitali skomercjalizowanych, częś́ szpitali prywatnych, ale niewatpliwie większość dotyczylaby wszystkich szpitali na poziomie powiatowym. To znaczy, wydaje się, że możliwe jest stworzenie systemu mierników $i$ metod pomiaru pozwalajacego na realne $i$ uczciwe obiektywne oceny. I chciatbym, żeby coś takiego byto wypracowane, chociażby w kontekście kontraktów z NFZ $i$ nawet oceny zarzadów tych szpitali. Bo gdyby byt realny, naprawdę bardzo rzetelny ranking, pokazujacy, gdzie punkty $z$ oceny ofert sa pogubione, a gdzie 
sq uzyskane dodatkowo, ten ranking bytby metodycznie trudny do podważenia, to niewatpliwie utatwitoby to nam kontrole zarzadcza i kierowanie funkcjonowaniem szpitala $z$ tego poziomu najwyższego, czyli walnego zgromadzenia akcjonariuszy.

Szpitale powiatowe działające $w$ formie prawnej S.A., z większościowym udziałem podmiotu tworzącego. Jeden ze szpitali jest szpitalem mającym w 100\% inwestora prywatnego. W tej grupie respondentów zdecydowanie opowiedziano się za tym, aby pomiar konkurencyjności opierał się na jednakowych zasadach. Kolejny rozmówca również uznał, że pomiar nie powinien się różnić, z zastrzeżeniem, że jeśli do zadań szpitala włączymy to, co wynika z tzw. interesu społecznego, to wówczas niektóre dziedziny działania nie powinny być oceniane podobnie jak ocenia się prywatne szpitale, ponieważ ten tzw. interes społeczny zakłóca porównanie i różni te szpitale od szpitali nastawionych typowo na realizację procedur przynoszących zysk. Ostatni respondent w tej grupie uważał, że pomiar powinien się różnić, ponieważ, jak twierdził, szpitale publiczne działają na rynku po to, by być transparentne i ich zadaniem tak naprawdę jest ujawniać wszystkie swoje aspekty działalności, natomiast prywatne szpitale bardziej muszą skrywać informacje, które mogą być wykorzystane przez konkurencję, zwłaszcza w aspekcie możliwości przejęcia takiej placówki przez inną, co jest zdecydowanie łatwiejsze wobec prywatnych szpitali niż publicznych.

W przypadku pytania trzeciego (tego bloku badawczego), respondenci z grupy Ministerstwa Zdrowia i Urzędu Wojewódzkiego, wyrazili opinię, że dokonywany systematycznie pomiar konkurencyjności szpitali wpłynie korzystnie na ten sektor rynku i nie wiąże się zasadniczo z zagrożeniem, pod warunkiem jednak, że wybrane kryteria pomiaru będą adekwatne do rzeczywistości. Jeden z respondentów uzasadniał swoją opinię w następujący sposób:

wydaje się, że z punktu widzenia centralnego nie widzę żadnych zagrożeń. Sa to tylko i wyłacznie korzyści. Tylko tutaj znowu, pomiar konkurencyjności w tym aspekcie, o którym mówimy, czyli pewnego dostępu do świadczeń, w tym momencie na pewno jest bardzo ważna, systemowa informacja dla ministra zdrowia, ale również wyobrażam sobie, dla ministra finansów czy nawet ministra rozwoju regionalnego, określenie, jak wyglada struktura dostaw na tym rynku. Możemy się zgodzić oczywiście i to już wielokrotnie stwierdzono i opisywano, że krótkie, najczęściej jednodniowe pobyty w szpitalu sa absolutnie przysztościa, tylko że poza ta forma świadczeń, sa również inne świadczenia. Jeżeli $z$ ocen wyniknie, że struktura rynku jest taka, że bardzo mocne mamy inwestowanie we wszystkie jednodniowe jednostki, to nie jest zupetnie bez wplywu na szpitale publiczne. Ponieważ to sa ci sami lekarze, którzy będq mieli 
takie a nie inne presje płacowe, które będa z kolei przektadaty się na presje na Narodowy Fundusz Zdrowia odnośnie odpowiednich kontraktów. To jest system naczyń potaczonych. I tego się absolutnie nie da ominać. [...] wracajac do tezy o konkurencyjności nieokietznanej, w szeregu krajów, na przykład w Niemczech, nie można tączyć rynku publicznego z prywatnym. U nas te sektory się przenikaja ze wszystkimi plusami i minusami tej sytuacji. Dlatego wydaje mi się, że takie systemowe analizy sa jak najbardziej konieczne, jak najbardziej potrzebne, ponieważ, nie jest to stricte wolny rynek [...], dlatego interwencja państwa zaktada, że musimy mieć pewne systemowe narzędzia, które pomoga stymulować konkurencje [...], w sektorze zdrowotnym odbywa się to poprzez odpowiednie taryfy, odpowiednie polityki kontraktowania i wówczas określone segmenty rynku sa promowane [...], dlatego wydaje się, że taki jednolity zestaw wskaźników, który by jasno i transparentnie pokazywat, jakie sa potrzebne kierunki interwencji, na pewno jest bardzo wskazany.

Natomiast rozmówca Urzędu Ochrony Konkurencji i Konsumentów wskazał na korzyści płynące z dokonywania pomiaru, ponieważ ma on generalnie przysłużyć się pacjentom, aby placówki medyczne za pomocą takiego pomiaru dążyły do poprawy wadliwych elementów oceny. Zagrożenie, jakie może płynąć z takiego pomiaru konkurencyjności, to sytuacja, w której okaże się, że pomiar będzie wadliwy, nie będzie mierzył tego, co powinien mierzyć i jeżeli jeszcze na tak wadliwym pomiarze opierać ma się ocena szpitali przez pacjentów, będzie to sytuacja najbardziej niepożądana.

Narodowy Fundusz Zdrowia, również jak respondenci z poprzednich grup interesariuszy, wyraził opinię, że systematyczny pomiar konkurencyjności szpitali powiatowych przyniesie korzyści, natomiast zagrożenia, jakie mogą powstać, to te, że w którymś momencie może się okazać, że pewne placówki po prostu wypadną z rynku. Okażą się być bardzo słabymi podmiotami, co może wiązać się z koniecznością podjęcia bardzo niepopularnych społecznie decyzji o likwidacji takich szpitali. Dlatego nie każdemu takie rozwiązanie może się podobać.

Starostwie, na terenie których działają szpitale powiatowe w formie SPZOZ - w tej grupie respondenci dostrzegają korzyści płynące z dokonywania w sposób systematyczny pomiaru konkurencyjności, jednakże, podobnie jak poprzednie grupy, wskazali na fakt, aby mierniki były adekwatne do rzeczywistości i pomiar był dokonywany jak najbardziej uczciwie, aby można było mieć do tego narzędzia pełne zaufanie. Zagrożenie, jakie się tu wyłania, to fakt, że po dokonywaniu tego typu ocen okaże się, że niektóre szpitale są niepotrzebne, co z punktu widzenia racjonalizacji potrzeb zdrowotnych jest na pewno wskazane. 
Z punktu widzenia szpitali powiatowych SPZOZ, wyrażono opinię, że systematyczne dokonywanie pomiaru konkurencyjności przynosi korzyści. Ważne jest, aby był on dokonywany uczciwie, należałoby takie narzędzie spopularyzować nie tylko wśród zarządzających szpitalami, ale przede wszystkim wśród organów założycielskich i pozostałych interesariuszy systemu zdrowotnego i wprowadzić do powszechnego użytku. Ważne jest to, aby zastanowić się nad tym, jaka instytucja godna zaufania publicznego prowadziłaby tego typu pomiary i w jaki sposób weryfikować ich poprawność.

Starostwie, na których terenie działają szpitale powiatowe o formie prawnej Sp. z o.o., z większościowym udziałem podmiotu tworzącego, w tej grupie respondenci wyrazili dość ciekawą opinię, że systematyczny pomiar konkurencyjności przyniesie korzyści w postaci swojego rodzaju nauki od innych, co w ostateczności wpłynie na poprawę działalności szpitala, gdyż będzie dążył on do dorównania najlepszym. Ważne jest, by mierniki pomiaru były przemyślane i dostosowane do rzeczywistości. Jeden z rozmówców wskazał, że nie widzi żadnych zagrożeń tego pomiaru, gdyż uważa, że szpitale ze sobą nie konkurują w obecnie funkcjonującym systemie zdrowotnym.

Szpitale powiatowe działające $w$ formie prawnej $\mathrm{Sp}$. $\mathrm{z}$ o.o., $\mathrm{z}$ większościowym udziałem podmiotu tworzącego, w tej grupie rozmówców, również wskazano na korzyści płynące z dokonywania systematycznie pomiaru konkurencyjności, przy czym pojawiły się głosy, że ważnym jest, kto i do czego tę wiedzę będzie wykorzystywał. Dlatego należałoby najpierw ustalić bardzo transparentne zasady pomiaru i oceny uzyskanych wyników dla poszczególnych zainteresowanych, aby pomiar był jak najbardziej uczciwy. Jeden z rozmówców wskazał, że taki pomiar będzie bardzo pomocny dla pacjentów, gdyż pomoże na podstawie merytorycznych informacji uzyskać sprawdzoną wiedzę, a nie oceniać dany szpital na temat niesprawdzonych informacji bądź też doniesień medialnych. Inny rozmówca wskazał, że:

zagrożenia na pewno z tego nie wynikaja. Oczywiście zależy to od tego, jak ta wiedza będzie wykorzystywana. Ja mocno obawiam się tego, że NFZ przygotowuje się $w$ tej chwili do prowadzenia zdalnej oceny efektywności szpitali, bo problem nie polega nawet na tym, że te dane będa zbierane tylko na tym, że te dane będa oceniane bez petnej wiedzy na temat warunków funkcjonowania konkretnych szpitali. Bo inne koszty funkcjonowania będzie miat szpital świeżo wybudowany, ze środków unijnych, w którym nic się nie psuje i niczego nie trzeba odtwarzać. A zupetnie inne koszty funkcjonowania będzie miat szpital, który mieści się w kilkusetletnich budynkach. I tego nie widać w analizie efektywności kosztowej, a ma to ogromne znaczenie z punktu widzenia funkcjonowania szpitali. 
Starostwie, na których terenie działają szpitale powiatowe o formie prawnej S.A., z większościowym udziałem podmiotu tworzącego. Jeden ze szpitali jest szpitalem mającym w 100\% inwestora prywatnego. Respondenci z tej grupy wyrazili opinię, że pomiar konkurencyjności szpitali przyniesie korzyści. Ważne jednak, aby uzyskane wyniki miały wpływ i przełożenie na konkretne podejmowane decyzje odpowiednich grup interesariuszy co do kierunków dalszych działań szpitali. Jeden z rozmówców wskazał, że w przypadku opublikowania takich danych dla pacjentów, może to wywołać nieprzewidziane efekty:

to wszystko będzie zależeć od tego, czy to będzie dokument jawny dla każdego pacjenta, czy to będzie informacja ukryta dla sfer tylko zarzadczych. Jeżeli będzie to informacja ukryta, to bardzo dobrze, gdyż pozwoli to podejmować optymalne decyzje inwestycyjne, wtaścicielskie, $w$ zależności od propozycji składanych przez zarzad spótki szpitalnej. Jeżeli natomiast te dane bylyby opublikowane dla szarego grona interesariuszy, to jest to swego rodzaju bomba $z$ opóźnionym zaptonem, ponieważ odbiorcy tych informacji będq kierować się na leczenie do tych szpitali, które będa miaty najlepsze wskaźniki, jak: najkrótsze czasy oczekiwania, więc należy liczyć się z tym, że może to wplywać w sposób sztuczny na wzmocnienie pozycji tych placówek, których wskaźniki sq w tym momencie korzystniejsze od konkurencji. Co niekoniecznie musi być dobre dla wtaściciela.

Szpitale powiatowe działające w formie prawnej S.A., z większościowym udziałem podmiotu tworzącego. Jeden ze szpitali jest szpitalem mającym w 100\% inwestora prywatnego. W tej grupie rozmówców również została wyrażona opinia, że systematyczny pomiar konkurencyjności szpitali wpłynie korzystnie na ich działalność pod warunkiem, że zmienią się uwarunkowania, przede wszystkim prawne, sprzyjające racjonalnemu rozwojowi sektora zdrowotnego w Polsce. Oto jedna z opinii respondenta tej grupy uzasadniająca te poglądy:

zagrożenia ptynace z pomiaru na pewno będa takie, że bardzo tatwo jest wtedy ulokować się na rynku, wiedząc na jakim poziomie jest inny szpital. Doskonale możemy przewidzieć, jakie może mieć ktopoty, co możemy wykorzystać w swojej strategii i za określony czas, możemy wejść na dany rynek zdrowotny, a nasz konkurent może mieć $z$ tego tytułu ktopoty. Takie trochę madre podgladanie. I to jest w mojej opinii zagrożenie. Sadze jednak, że jeszcze wiele lat uptywnie, zanim będziemy mogli otwarcie o tym rozmawiać. Korzyści? To na pewno to, że im wyżej będzie postawiona poprzeczka, czyli jeżeli dla danego obszaru dziatania szpitale potrafia uporzadkować i poprawić bezpieczeństwo i jakość tego pacjenta, to ja również do tego dążę. Konkurencyjność wptywa pozytywnie na jakość świadczonych ustug i bezpieczeństwo, a to jeszcze w polskim systemie 
zdrowotnym jest na najniższym poziomie. Biorac pod uwage analizy szpitali światowych, europejskich, my jesteśmy jeszcze bardzo, bardzo daleko, jeśli chodzi o rejestrowanie na przyktad zdarzeń niepożadanych. To jest jeszcze temat nieznany niektórym szpitalom, gdzie uważa się, że to jest odkrywanie swoich btędów, nieprawidtowości. Jest wiele $w$ tym względzie do zrobienia. A zatem uważam, że sq i zagrożenia, $i$ korzyści. Ale musimy nauczyć się rozmawiać o tym otwarcie. Może będzie to bardziej możliwe w przysztości, jeżeli będzie uwolniony rynek, jeśli chodzi o ptatnika. Jeżeli na rynek wejda jeszcze ubezpieczenia dodatkowe, nie będzie to jeden ptatnik, tak jak obecnie. Wówczas zapewne będziemy rozmawiać na zupetnie innych poziomach. I tego oczekujemy w przysztości.

Jak widać z przedstawionych powyżej opinii, zarówno temat konkurencyjności szpitali powiatowych, jak i jej pomiaru jest tematem postrzeganym przez każdą grupę interesariuszy jako ważny. Wielu z rozmówców widzi, iż mierniki konkurencyjności mogą przyczynić się do rozwiązania wielu problemów polskich pacjentów i polskiego systemu zdrowotnego, jeśli zostaną wprowadzone do tego systemu przemyślane regulacje prawne, wprowadzające pewne mechanizmy rynkowe, które umożliwią rozwój i optymalne wykorzystanie potencjału tego działu gospodarki.

\section{Proponowane kierunki pomiaru konkurencyjności szpitali powiatowych - rekomendacje w oparciu o analizę rankingów oraz wyników uzyskanych z przeprowadzonego badania własnego}

W oparciu o przeprowadzoną analizę porównawczą rankingu polskich szpitali z rankingiem szpitali w Szwecji na pierwszy plan wysuwa się podstawowa różnica w podejściu do pomiaru. Dotyczy ona tego, że w Szwecji dokonuje się pomiaru przede wszystkim w oparciu o uzyskiwane efekty leczenia. Jedynie kwestie ekonomiczne są rozpatrywane w szpitalach uniwersyteckich. Przy czym bardziej chodzi tu o porównanie kosztów w zakresie realizacji poszczególnych grup JGP (DRG). Ponadto, szpitale w Szwecji są podzielone na trzy grupy: uniwersyteckie, średnie i małe. W Polsce dokonuje się oceny szpitali, dzieląc je również na trzy grupy, ale pod kątem szpitali zabiegowych wielospecjalistycznych, zabiegowych monospecjalistycznych i niezabiegowych. Już ten podział budzi wątpliwości, czy jest on prawidłowy, gdyż wśród szpitali zabiegowych wielospecjalistycznych znajdują się zarówno szpitale kliniczne, wojewódzkie, jak i powiatowe. Czy porównywanie tych trzech typów szpitali ze sobą jest miarodajne? Zapewne nie, już chociażby biorąc pod uwagę wysokość posiadanych 
kontraktów tych szpitali, widać znaczącą różnicę w ich przychodach, co ma wpływ na koszty i zadłużenie poszczególnych placówek. Ponadto, każdy z tych szpitali ma swoją specyfikę i swoje problemy, z którymi boryka się w codziennej działalności, co nie jest bez znaczenia w aspekcie dokonywania rzetelnych porównań.

W polskim rankingu, co wskazano w analizie rankingów, główną uwage zwraca się na infrastrukturę szpitali, wyposażenie, posiadany sprzęt itp. Obszary A, C, E, które wypadły najlepiej w przeprowadzonym rankingu w 2013 roku dotyczą typowo zagadnień związanych z posiadaną przez szpital infrastrukturą i sprzętem diagnostycznym. Jak się okazuje, warto podjąć trud inwestowania, gdyż przekłada się to na pozyskanie wysokiej pozycji szpitala w rankingu. Jednakże nietrudno zauważyć, że wśród szpitali wysuwających się na czoło rankingu znajdują się w większości placówki, które dokonały poważnych inwestycji budowlanych i technicznych, korzystając $w$ dużej mierze $\mathrm{z}$ dofinansowania unijnego. Tego typu inwestycje wymagają sporych nakładów pieniężnych i sfinansowanie ich w ramach środków otrzymywanych z tytułu kontraktów, jakie szpital posiada z Narodowym Funduszem Zdrowia, jest właściwie nierealne, zwłaszcza gdy placówka jest zadłużona.

Nasuwa się zatem pytanie o to, czy np. szpital, który posiada nowoczesny blok operacyjny, czy też nowoczesną centralną sterylizację, albo kosztowny sprzęt diagnostyczny, np. rezonans magnetyczny, efektywnie wykorzystuje dane pomieszczenia i urządzenia, czy liczba dwóch lub nawet trzech bloków operacyjnych nie okazuje się być infrastrukturą na wyrost, która generuje tylko koszty, gdyż jest nieumiejętnie wykorzystana i zarządzana, gdyż zupełnie nie odpowiada potrzebom danego szpitala, regionu itp.

Stąd też rodzi się pewna obawa, że szpital odpowiadający pozytywnie na pytania dotyczące poszczególnych obszarów ujętych w ankiecie będzie wprawdzie prezentował się $\mathrm{w}$ rankingu jako placówka nowoczesna pod względem technicznym i diagnostycznym, spełniająca wszelkie wymogi prawne, ale niestety nie uzyskamy odpowiedzi na to, czy infrastruktura i wyposażenie diagnostyczne szpitala zostało dostosowane także, oprócz wymogów ustawowych, do aktualnych wymogów i potrzeb demograficznych i rodzaju prowadzonej działalności placówki w regionie. Co ważne, nie dowiemy się także, czy środki finansowe, poniesione na przeprowadzenie przebudowy i modernizację infrastruktury i zakupu sprzętu, nie zostały po prostu zmarnotrawione, gdyż mogły zostać przeznaczone na rozwój innych, bardziej konkurencyjnych względem rywali obszarów działalności szpitala.

Nie bez znaczenia jest też fakt, że wymogi techniczne i sprzętowe, o których mowa w poszczególnych obszarach oceny, w większości stanowią podsta- 
wę istnienia każdej placówki medycznej. Decydują one o tym, czy dany szpital będzie mógł realizować w ogóle działalność leczniczą, ponieważ są elementarnym wymogiem prawnym, nałożonym przez Ministerstwo Zdrowia i Narodowy Fundusz Zdrowia. Stąd tak ważne jest, by ocenić, czy wymagania stawiane przed szpitalami są dostosowane do realiów i faktycznych potrzeb, a zasoby posiadane przez placówki medyczne są prawidłowo rozlokowane.

W 2013 roku w rankingu uczestniczyło 243 szpitale, a co działo się z pozostałymi placówkami?

Szpitale, które nie zdecydowały się przystąpić do badania, podjęły taką decyzję zapewne z uwagi na niespełnienie przez nie wszystkich wymogów, które są przedmiotem analizy tegoż rankingu, a które stanowią podstawowe standardy, jakie powinna spełniać współczesna placówka medyczna. Główną przyczyną rezygnacji szpitali z uczestnictwa $w$ rankingu będzie ich niezbyt dobra sytuacja finansowa. Obszar $\mathrm{O}-\mathrm{w}$ którym szpital podaje podstawowe wskaźniki ekonomiczne, m.in. wielkość zadłużenia placówki i jej płynność, w wielu przypadkach nie przedstawia się optymistycznie. Analiza kosztów utrzymania placówek medycznych wskazuje, że rosną one nieproporcjonalnie do wartości kontraktów, jakie podmioty te podpisują z Narodowym Funduszem Zdrowia. Obciążenia nakładane na szpitale są coraz wyższe, chociażby z racji nowych obowiązkowych ubezpieczeń, stawek VAT itp. Z roku na rok zmniejsza się liczba szpitali, które mogą się pochwalić dodatnim wynikiem finansowym. Ponadto, szpitale mają problemy z uzyskaniem płatności z Narodowego Funduszu Zdrowia za świadczenia wykonane ponad limit oraz, nierzadko, z wynegocjowaniem korzystnego kontraktu. Trzeba też pamiętać, że wzrost finansowania świadczeń medycznych mógłby się wiązać z potrzebą wzrostu składki zdrowotnej. Dlatego należałoby spojrzeć na ten aspekt także od strony skutecznego zrządzania placówką nie tylko przez samego dyrektora, ale także poszczególnych ordynatorów i kierowników komórek organizacyjnych szpitala.

Wskaźniki prezentowane przez szpitale $\mathrm{w}$ ramach obszaru $\mathrm{O}$ są zależne od wielu czynników, dlatego też i tutaj należałoby poszerzyć ilość informacji, np. o dane dotyczące wielkości przyznanego kontraktu, wielkości świadczeń zapłaconych i świadczeń niezapłaconych przez płatnika w poszczególnych rodzajach umów, bądź też wyników pozyskiwanych przez poszczególne komórki szpitala.

W przypadku danych jakościowych, związanych z obsługą pacjenta, kryteria, według których są oceniane szpitale, skupiają się bardziej na tym, czy szpital posiada i czy realizuje określone działania, jednakże brak jest w nim odniesienia do tego, jakie wyniki uzyskał $\mathrm{w}$ związku $\mathrm{z}$ realizacją tych czynności. Przykładowo, w ramach obszaru J - zadano pytanie, czy szpital prowadzi 
wśród pacjentów i personelu szpitala badanie satysfakcji. Załóżmy, że szpital prowadzi tego typu badanie i odpowie pozytywnie na pytanie ankietowe, ale co wynika z tego faktu, że je wykonuje? Oprócz tego, że szpital je realizuje, interesuje nas także to, jakie wyniki uzyskał z przeprowadzonego badania satysfakcji pacjentów czy personelu i jakie kroki podjęli zarządzający szpitalem, aby dokonać poprawy w zakresach, które tego wymagają.

Podobnie w przypadku obszaru M - skargi i zdarzenia niepożądane, pacjenci zapewne byliby zainteresowani nie tylko tym, czy w szpitalu działa rzecznik praw pacjenta i czy prowadzi się analizę przyczynowo-skutkową zdarzeń niepożądanych. Pacjenci będą też zainteresowani tym, jakie działania, zmierzające do tego, by ograniczyć tego typu przypadki oraz efekty tych działań, są podejmowane, a wszystko po to, aby pacjent miał zaufanie do personelu medycznego, co znacznie wpływa na poprawę komfortu jego leczenia.

Dane jakościowe są z reguły danymi trudno mierzalnymi, jednakże w tym aspekcie należy opracować takie mierniki, które pozwolą ocenić szpital pod kątem jego konkurencyjności w zakresie jakości świadczeń. O jakie dane należałoby uzupełnić analizy potencjału konkurencyjności szpitali?

Otóż, jak wspomniano powyżej, szpital nie może się tylko ograniczać do stwierdzenia suchych faktów typu: posiadam bądź nie posiadam certyfikatu akredytacyjnego. Może należałoby raczej zapytać o wyniki, jakie uzyskały szpitale podczas akredytacji, czy też: posiadam lekarzy specjalistów. A może należałoby zapytać o doświadczenie tych lekarzy itp. Niezmiernie istotne jest też branie pod uwagę preferencji pacjentów, renomę szpitali, osiągane wyniki leczenia i rzeczywiste umiejętności personelu medycznego.

Bo jak wiadomo, szpital będzie postrzegany jako konkurencyjny, gdy skupi się na tym, by dążyć do poprawy osiąganych wyników, i to w każdym wymiarze swojej działalności, oraz stosunkowo wcześnie zapobiegać wszelkim zagrożeniom, jakie pojawiają na drodze w dążeniu do osiągnięcia zrównoważonego rozwoju. Dlatego niezmiernie ważna jest ocena osiąganych wyników przez szpital, obok tego czy i jakie placówka posiada wyposażenie techniczne, sprzętowe i informatyczne.

W przypadku rankingu szwedzkich szpitali w pierwszym momencie wydawać by się mogło, że ograniczenie kryteriów oceny do danych medycznych i związanych z nimi uzyskiwanych efektów leczenia, ogranicza poznawczo dany ranking. Jednak okazuje się, że przyjęty sposób oceny szwedzkich szpitali jest jak najbardziej prawidłowy, gdyż porównywanie wyżej wymienionych kryteriów pozwoli szpitalowi na:

- dokonanie wyboru i zaplanowanie projektów poprawy wydajności opartych na efektach leczniczych, 
- uniknięcie błędów, które już zostały popełnione,

- poznanie mocnych i słabych stron prowadzonej działalności,

- zdiagnozowanie obszarów, które wymagają pilnej poprawy,

- zoptymalizowanie produktywności i efektywności wykorzystania zasobów.

A to wszystko w oparciu o uzyskane efekty lecznicze, które w przypadku szpitala mówią najwięcej o jego efektywności, wydajności, optymalizacji kosztów i trafnym wykorzystaniu zasobów. Ranking „Dagens Medicine” prezentuje placówki, zapewniające najlepszą opiekę medyczną poprzez legitymowanie się najlepszymi efektami w leczeniu poszczególnych schorzeń. Interesariusze szpitali, a zwłaszcza pacjenci, na podstawie przeprowadzonego rankingu wiedzą, gdzie najbezpieczniej mogą się leczyć i komu można powierzyć los najbliższych z pełną odpowiedzialnością. Do oceny placówek i ich usług posłużyła metodyka opracowana przez specjalistów z poszczególnych dziedzin medycznych. Wybrano te zabiegi i schorzenia, których leczenie najlepiej świadczy o profesjonalizmie danego rodzaju szpitala.

Dużą zaletą tak przeprowadzonego rankingu jest fakt, iż wszystkie określone w nim kryteria oceny są łatwe do zweryfikowania przez osoby postronne, gdyż wszystkie tego typu informacje znajdują się na stronach internetowych poszczególnych np. powiatów, gdzie pacjenci mogą sprawdzić i dowiedzieć się, jaki jest np. w danym momencie czas oczekiwania na leczenie określonego schorzenia. Ponadto, są publikowane raporty z przeprowadzanych kontroli w szpitalach oraz raporty jakości publikowane przez szpitale, co było już przedmiotem rozważań w rozdziale poświęconym modelom biznesowym poszczególnych szpitali. Taka analiza działalności szpitala jest oceną skuteczną nie tylko pod względem medycznym i ekonomicznym, ale również pod względem oceny konkurencyjności szpitala.

Jak widać, ocena konkurencyjności szpitali w Szwecji zawiera elementy oceny nakierowane na osiągane przez szpitale wyniki, czego, jak wskazano wcześniej, brak w analogicznym rankingu „Bezpieczny Szpital” przeprowadzanym w Polsce.

Ocena szpitala pod kątem jego konkurencyjności powinna dążyć do tego, by obiektywnie określić, czy hospitalizacja realizowana w danym szpitalu będzie przebiegać w warunkach co najmniej optymalnych, czy też leczenie będzie prowadzone z pominięciem elementarnych zasad i ogólnie przyjętych standardów postępowania.

Należy podkreślić, że wszelkie rankingi nie mogą zastąpić precyzyjnych i wiarygodnych, informacji o jakości pracy szpitali, publikowanych m.in. przez Ministerstwo Zdrowia, Narodowy Fundusz Zdrowia, organy właścicielskie 
szpitali itp., ale zanim zaczną się one pojawiać regularnie, rankingi mogą spełniać funkcję doradczą, gdyż prawo do dokonywania wyborów pomiędzy konkurencyjnymi szpitalami, tylko wtedy ma wartość, kiedy istnieją jasne i precyzyjnie określone kryteria wyboru. Krótko mówiąc, kiedy mamy świadomość pomiędzy czym wybieramy. W przypadku pacjenta ma to szczególne znaczenie, gdyż chodzi tu o jego zdrowie i życie.

Z przeprowadzonego badania wynika, że ocena działalności szpitali jest bardzo niejednorodna. Każda z instytucji skupia swoją ocenę raczej na tym, co uważa dla siebie za bardziej istotne niż np. dla pacjenta. Taka sytuacja wynika stąd, że obecnie nie ma jasno sprecyzowanego jednego modelu pomiaru działalności szpitali. Ministerstwo Zdrowia i urzędy wojewódzkie w swoich ocenach szpitali skupiają się przede wszystkim na szerokiej ocenie działalności finansowej placówki czy też badaniu jej zadłużenia. Rozmówcy reprezentujący te instytucje dostrzegają brak istnienia wzorcowego teoretycznego modelu konkurencyjności w polskiej służbie zdrowia. Jak zauważają, jeśli będą mieli taki teoretyczny, gruntownie przemyślany model konkurencyjności, wówczas możliwe będzie zobiektywizowanie problemu i dokonywanie korzystnych i sensownych analiz działalności szpitali.

UOKiK również nie dokonuje pomiarów i porównań szpitali pod kątem konkurencyjności ani nie przeprowadza żadnych tego typu analiz. Jednakże rozmówca również słusznie zauważył, że mierniki pomiaru konkurencyjności szpitali powinny być tak dobrane i skonstruowane, by służyły przede wszystkim pacjentowi, a nie szpitalom czy innym grupom interesariuszy systemu. Z kolei w przypadku NFZ - rozmówcy wskazali, że płatnik ocenia szpitale zgodnie z wytycznymi i wymogami wynikającymi z rozporządzeń ministra zdrowia i innych aktów prawnych, które jasno określają, jakie warunki (np. lokalowe, sprzętowe czy kadrowe) muszą spełnić szpitale, aby móc udzielać świadczeń medycznych. A zatem ocena szpitala jest tu bardzo zbliżona do oceny placówki w rankingu „Bezpieczny Szpital”, o czym dokładniej pisano powyżej. Ważne jest, że szpitale przekazują do płatnika swoją sprawozdawczość z wykonanych świadczeń medycznych, co jest podstawą do rozliczenia się placówki z NFZ. Przekazane dane medyczne są też wykorzystywane przez płatnika podczas negocjacji wysokości kontraktów. NFZ dokładnie wie, jakie świadczenia, jakie schorzenia, a także jaki odsetek rehospitalizacji czy reoperacji był wykonany u danego świadczeniodawcy. Niestety, informacje te pozostają tylko do wiadomości płatnika, a tak zachowuje się na rynku typowy monopolista, który dąży do pozyskiwania jak największej ilości informacji i w konsekwencji do kontrolowania tego rynku. Tego typu działania zupełnie nie służą transparentności działania tej instytucji. Obecnie mamy jednego płatnika, Narodowy Fun- 
dusz Zdrowia. Jego struktura i działalność nie są do końca transparentne, co potwierdza ostatni raport Najwyższej Izby Kontroli (Informacja o wynikach kontroli, 2014, s. 1-47). Jest to podstawowa cecha każdego monopolisty, który będzie rezerwował informację tylko dla siebie i działał tak, by tego monopolu nikt nie był w stanie regulować i kontrolować. W przypadku przedstawicieli starostw $\mathrm{z}$ wykonanego badania uzyskano informację, iż starostowie nie korzystają z żadnych jednolitych systemów oceny szpitali, a jeśli takie powstają, to głównie z ich inicjatywy. Wówczas porównywanie szpitali jest dokonywane za pośrednictwem Konwentu Starostów czy Związku Powiatów Polskich, przy czym pomiar dotyczy raczej analizy finansowej, a nie jakościowej. W tej grupie pytanych znajdowały się też osoby, które nie były zainteresowane oceną szpitali, gdyż, jak twierdziły, nie była to dla nich istotna kwestia. Dość niepokojący jest fakt, iż zarówno urzędy centralne, jak i lokalne nie dokonują systematycznych pomiarów działalności szpitali, a jeżeli już są one realizowane to tylko wyrywkowo i w zdecydowany sposób nakierowane na analizę finansową, z pominięciem analizy jakościowej. Jak zatem i na jakiej podstawie mogą być podejmowane przez decydentów poszczególnych szczebli trafne decyzje zarządcze. Przecież, nie mając konkretnych i weryfikowalnych danych o działalności poszczególnych szpitali, najczęściej decyzje te są podejmowane intuicyjnie. Równie niepokojący jest fakt, że właściwie starostowie, którzy są odpowiedzialni za zapewnienie opieki mieszkańcom ich powiatu, nie do końca są zainteresowani tym, jak działa szpital na ich terenie. Jest to o tyle interesujące, że wraz z wejściem w życie ustawy z 15 kwietnia 2011 roku o działalności leczniczej, podmiot tworzący ponosi koszty strat swoich szpitali. Jeśli nie jest w stanie tego zrealizować wówczas następuje przekształcenie szpitala w spółkę prawa handlowego.

Jak zatem jest dokonywana ocena działalności szpitali przez zarządzających tymi placówkami? W tym przypadku kadra zarządzająca nie korzysta z sformalizowanych modeli pomiaru, większość z nich dokonuje oceny szpitala w oparciu o takie kryteria finansowe, jak: analiza kontaktów, jego wykonanie, analiza kosztów. Niektórzy zarządzający korzystają z benchmarkingów prowadzonych przez prywatne firmy, przy czym zakres danych, jakie są analizowane, ma charakter typowy i sprowadzają się one raczej do typowych wskaźników ekonomicznych. Jeden z rozmówców wskazał, że benchmark niestety nie pomaga mu w podejmowaniu decyzji zarządczych, ponieważ obecny rynek zdrowotny, z uwagi na swoje ograniczenia, nie pozwala mu na podejmowanie swobodnych decyzji zarządczych. Większość zarządzających ocenę jakościową szpitala ogranicza do analizy wskaźników ściśle określonych standardami akredytacyjnymi. 
Jeśli chodzi o fakt, czy pomiar powinien być jednolity, czy różny dla poszczególnych rodzajów szpitali, to generalnie rozmówcy opowiadali się za jednolitym sposobem pomiaru konkurencyjności w szpitalach powiatowych, gdyż - jak argumentowali - forma prawna nie ma większego znaczenia dla pacjenta. Dla pacjenta ważny jest efekt leczenia, a nie rodzaj szpitala, do którego trafi na terapię.

Jakie pojawiły się w tym względzie inne propozycje? Otóż respondenci ponadto zwrócili uwagę na dość istotny aspekt dotyczący uwarunkowań, w jakich działają szpitale wojewódzkie czy powiatowe, dlatego z tej perspektywy na pewno pomiar powinien uwzględniać pewne aspekty wpływające na zróżnicowanie działalności tych szpitali, co powinno znaleźć odzwierciedlenie w odpowiednio dobranych kryteriach pomiaru konkurencyjności. Wskazano również, że na różnicowanie pomiarów szpitali może wpływać stopień ich „referencyjności”, gdyż nieco inaczej może działać szpital wielospecjalistyczny zabiegowy, a inaczej szpital monospecjalistyczny zabiegowy lub niezabiegowy. Zauważono, że w przypadku publicznych szpitali, niezależnie od formy prawnej, mierniki oceny powinny być jednakowe, natomiast szpitale prywatne powinny być porównywane oddzielnie, według innych mierników. Inny rozmówca wskazał, że mierniki oceny konkurencyjności szpitali powiatowych powinny się różnić między sobą, ponieważ z uwagi na brak stabilizacji gospodarczej oraz polskiego systemu zdrowotnego, gdzie nie dopracowano się nadal gruntownych filarów regulacyjnych, wyniki otrzymane z takiej oceny mogłyby nie być adekwatne do rzeczywistości i mogłyby być zrozumiane opacznie przez odbiorców. Kolejny rozmówca zaznaczył, że różnica w pomiarze powinna dotyczyć podatku i dzierżawy, ponieważ one nie występują w SPZOZ. W podobnym tonie wypowiedział się inny respondent, który uznał, że różnica w pomiarze powinna uwzględniać sposób traktowania amortyzacji; nieco odmienny w spółkach i nieco odmienny w szpitalach publicznych. Dość ciekawy pogląd wskazał następny rozmówca, który uznał, że pomiar nie powinien się różnić, z zastrzeżeniem, że jeśli do zadań szpitala włączymy to, co wynika z tzw. interesu społecznego, to wówczas niektóre dziedziny działania nie powinny być oceniane podobnie jak ocenia się prywatne szpitale. Ten tzw. interes społeczny zakłóca bowiem porównanie i różni te szpitale od szpitali nastawionych typowo na realizację procedur przynoszących zysk. Jeden z rozmówców uważał, że pomiar powinien się różnić, ponieważ, jak twierdził, szpitale publiczne działają na rynku po to, by być transparentne i ich zadaniem tak naprawdę jest ujawnianie wszystkich aspektów działalności. Natomiast prywatne szpitale bardziej muszą skrywać informacje, które mogą być wykorzystane przez konkurencję, zwłaszcza w aspekcie możliwości przejęcia 
takiej placówki przez inną, co jest zdecydowanie łatwiejsze wobec prywatnych szpitali niż publicznych.

Jak widać, zdecydowana większość rozmówców wyrażała opinię, iż pomiar szpitali powinien być jednakowy (forma prawna nie ma znaczenia). Do rozważenia zapewne jest propozycja dokonywania pomiaru z podziałem na szpitale powiatowe, wojewódzkie czy kliniczne oraz z punktu widzenia referencyjności tych placówek. Inne propozycje, jakie przedstawiali respondenci, np. odmienny pomiar dla szpitali publicznych i odmienny dla szpitali prywatnych oraz argumenty, jakie podawali, wyraźnie wskazuje na fakt, iż brak jest stabilizacji w zakresie polskiego systemu zdrowotnego, gdzie nie dopracowano się nadal gruntownych filarów regulacyjnych. Dlatego wskazane jest dalsze dążenie do tworzenia jasnych i właściwych ram prawnych w zakresie funkcjonowania całego systemu zdrowotnego w Polsce.

W odniesieniu do korzyści lub ryzyka z dokonywanego pomiaru konkurencyjności szpitali, respondenci w większości wyrazili opinię, że dokonywany systematycznie pomiar konkurencyjności szpitali wpłynie korzystnie na ten sektor rynku i nie wiąże się zasadniczo z zagrożeniem, pod warunkiem jednak, że wybrane kryteria pomiaru będą adekwatne do rzeczywistości. Główne zagrożenie, jakie może płynąć z takiego pomiaru konkurencyjności według respondentów, to sytuacja, w której okaże się, że pomiar będzie wadliwy, ponieważ nie będzie mierzył tego, co powinien mierzyć. Jeżeli jeszcze na tak wadliwym pomiarze opierać się ma ocena szpitali przez pacjentów, będzie to sytuacja jak najbardziej niepożądana. Do innych ewentualnych zagrożeń respondenci zaliczyli fakt, że w wyniku dokonywanych pomiarów może się okazać, że pewne placówki po prostu wypadną z rynku, bo okażą się być bardzo nieefektywnymi podmiotami. To może wiązać się z koniecznością podjęcia bardzo niepopularnych społecznie decyzji, np. o likwidacji takich szpitali. Dlatego nie każdemu takie rozwiązanie może się podobać.

Konkludując, z powyższego można wysnuć wniosek, iż systematyczny pomiar konkurencyjności szpitali wpłynie korzystnie na ich działalność, ale pod warunkiem, że zmienią się uwarunkowania przede wszystkim prawne i będą sprzyjały racjonalnemu rozwojowi sektora zdrowotnego w Polsce. Poza tym ważne jest, by pomiar był dokonywany uczciwie. Należałoby takie narzędzie spopularyzować nie tylko wśród zarządzających szpitalami, ale przede wszystkim wśród organów założycielskich i pozostałych interesariuszy systemu zdrowotnego i wprowadzić do powszechnego użytku. Ważne jest, aby zastanowić się, jaka instytucja godna zaufania publicznego prowadziłaby tego typu pomiary i w jaki sposób weryfikować ich poprawność, by była przestrzegana zasada przejrzystości i transparentności informacji. 
Podsumowując powyższe, poniżej przedstawiono diagnozę obecnego stanu w zakresie pomiaru konkurencyjności szpitali, będącą zarazem rekomendacją w zakresie konieczności podejmowania działań w kierunku uzyskania rzetelnej informacji o działalności poszczególnych placówek szpitalnych w Polsce:

- brak ujednoliconego systemu pomiaru konkurencyjności szpitali;

- brak wiarygodnych, łatwo weryfikowalnych, adekwatnych do rzeczywistości mierników pomiaru konkurencyjności szpitali;

- w przypadku już realizowanego w Polsce rankingu „Bezpieczny Szpital” brak oceny szpitali pod kątem uzyskanych efektów leczenia, co jest najistotniejsze z punktu widzenia pacjenta, a zbytnia koncentracja oceny na mniej istotnych wymogach, np. infrastrukturalnych, budynkach czy posiadanym sprzęcie;

- brak informacji o efektach działalności szpitali powszechnie dostępnej dla wszystkich interesariuszy systemu, szczególnie dla pacjentów; w chwili obecnej najwięcej informacji o szpitalach gromadzi płatnik, co jest typowe dla monopolistycznej pozycji NFZ w polskim systemie zdrowotnym,

- zarządzający szpitalem oraz przedstawiciele urzędów zarówno lokalnych, jak i centralnych najczęściej dokonują oceny szpitali w aspekcie osiąganych wyników finansowych i zadłużenia placówki;

- kadra zarządzająca, pomimo że wyraża potrzebę dokonywania systematycznego pomiaru konkurencyjności szpitali, nie odczuwa motywacji, aby taki pomiar realizować;

- interesariusze jako zagrożenie dla dokonywania systematycznego pomiaru konkurencyjności dostrzegają aspekt pojawienia się groźby likwidacji szpitali, które w wyniku oceny okażą się zbyt słabe, aby nadal funkcjonować, a to może pociągnąć za sobą implikacje zarówno społeczne, jak i polityczne;

- brak systematycznych i wiarygodnych pomiarów konkurencyjności szpitali uniemożliwia podejmowanie racjonalnych decyzji zarządczych zarówno na szczeblu lokalnym, jak i centralnym, co powoduje, iż obecnie większość decyzji jest podejmowana intuicyjnie;

- brak powszechnie dostępnej informacji o wynikach pomiaru poszczególnych szpitali uniemożliwia pacjentom (klientom) rynku medycznego dokonanie świadomego wyboru szpitala, w którym chcą być leczeni, a swobodny wybór placówki przez pacjenta jest przez tego typu działanie ograniczony;

- brak jasno sprecyzowanego teoretycznego modelu konkurencyjności szpitali, który stanowiłby podwaliny do określenia wiarygodnych mierników pomiaru.

Jak zatem widać, aby przedstawione mankamenty mogły zostać zniwelowane, koniecznym jest przede wszystkim określenie teoretycznego modelu kon- 
kurencyjności szpitali (w tym przypadku szpitali powiatowych), co pozwoli na precyzyjne wskazanie adekwatnych i wiarygodnych mierników pomiaru konkurencyjności szpitali.

\section{Wnioski}

Szpital stanie się konkurencyjny, gdy zarządzający nim będą dokonywali analizy danych na temat nakładów, uzyskanych wyników, efektywności prowadzonych procesów poprzez porównania swoich wyników względem istniejących i potencjalnych konkurentów na rynku. Benchmarking daje menedżerom ochrony zdrowia narzędzia zarządcze służące poprawie jakości świadczonych usług i poziomu konkurencyjności. Benchmarking pozwala zrozumieć aktualną pozycję konkurencyjną szpitala na tle innych placówek, wskazuje kierunki działań strategicznych, umożliwia też zidentyfikować potencjał rozwojowy i wybrać bądź skorygować realne cele, do którego dąży szpital.

Pacjentom natomiast benchmarking daje możliwość aktywnego włączenia się w kształtowanie rynku usług medycznych, poprzez dokonywanie wyboru szpitala, w którym chce być leczony, bo to właśnie pacjent stanowi kluczowy element konkurencji. Jego decyzja wpływa na interakcje pomiędzy świadczeniodawcami i w konsekwencji na decyzje podejmowane przez płatnika, czego obecnie jest brak na polskim rynku usług zdrowotnych. Stąd tak jest ważne, aby został zainicjowany mechanizm zabiegania o pacjenta - benchmarking daje taką możliwość.

To właśnie czynniki rynkowe, m.in. konkurencja, stają się przyczynkiem do zmiany stylu kierowania jednostkami służby zdrowia $\mathrm{z}$ administracyjnego na zarządczy. Nie ulega wątpliwości, że dalsze doskonalenie i upowszechnianie zintegrowanych i kompleksowych metod pomiaru konkurencyjności staje się ważnym zadaniem dla placówek służby zdrowia w Polsce.

Z wypowiedzi uzyskanych podczas przeprowadzania wywiadów z głównymi interesariuszami systemu wyłania się obraz ułomnej (nieefektywnej, niezdrowej) w wielu aspektach konkurencji, funkcjonującej na rynku usług medycznych. Gdyby konkurencja na tym rynku była silna i efektywna, a podejmowane decyzje w tym aspekcie nie budziłyby zastrzeżeń i wątpliwości, zapewne nie byłoby powodów przemawiających za tym, aby wprowadzić nowe mierniki konkurencyjności.

Przyczyną przedstawionego powyżej stanu jest brak konkurencji w polskim systemie ochrony zdrowia. Konkurencja jest w tej sferze całkowicie niepraktyczną i zamrożoną kategorią, gdyż nie chcą jej kluczowi interesariusze, pacjenci, co jest zaskakującym wynikiem uzyskanego badania, środowisko lekarskie, 
regulatorzy, o czym świadczą istniejące regulacje prawne. Konkurencyjność nie może narodzić się bez efektywnej konkurencji. Trzeba szukać takiego kompromisu pomiędzy wszystkimi interesariuszami systemu zdrowotnego, który stopniowo może przełamać sytuację patową i przekonać, że możliwy jest istotny wzrost konkurencyjności szpitali. Niestety, bez wspólnego porozumienia i zrozumienia problematyki nadal będzie następowało stopniowe marnotrawienie środków finansowych i zasobów sektora zdrowotnego.

W pracy wskazano na znaczenie rankingów szpitali w kształtowaniu ich konkurencyjności, po dokonaniu analizy porównawczej rankingu polskiego „Bezpieczny Szpital” z rankingiem „Bästa Sjukhuset” szpitali w Szwecji oraz innych rankingów w krajach zachodnich, a także w oparciu o przeprowadzone badanie jakościowe (IDI) wśród interesariuszy systemu, zdiagnozowano obecny stan w zakresie pomiaru konkurencyjności szpitali, będący zarazem rekomendacją dotyczącą konieczności podejmowania działań służących uzyskaniu rzetelnej informacji o działalności poszczególnych placówek szpitalnych w Polsce.

Niedosyt budzi wciąż brak jednoznacznej odpowiedzi na pytanie, jaki ostatecznie powinien być wzorcowy model polskiego systemu zdrowotnego, ponieważ praca skupiła się na jednym rodzaju szpitali powiatowych. Koniecznym jest spojrzenie na problematykę konkurencji i konkurencyjności z perspektywy wszystkich podmiotów leczniczych działających na rynku medycznym, zarówno na szczeblu krajowym, wojewódzkim, powiatowym, jak i gminnym. Pozwoli to określić w sposób kompleksowy docelowy model systemu zdrowotnego po to, aby uzyskać oczekiwane korzyści i budować trwałą wartość nie tylko dla podmiotów leczniczych, ale przede wszystkim dla pacjentów. W tym zakresie interesujących wniosków mogłaby dostarczyć analiza wyników badań, przeprowadzonych w podobny sposób jak w niniejszej pracy, wśród głównych interesariuszy systemu i pacjentów także na szczeblu wojewódzkim i krajowym. Ponadto, wskazuje się na konieczność przeprowadzenia badań na większych próbach badawczych w dłuższym okresie, a realizatorem badania powinien być kilkuosobowy zespół badawczy.

\section{Bibliografia}

Barney, J.B., Hestery, W.S. (2005). Strategic Management \& Competitive Advantage Concepts \& Cases. New York: Prentice Hall.

Cercone, J., O'Brien, L. (2010). Benchmarking Hospital Performance in Health, Sanigest International, 3.

Codagnone, C., Lupianez-Villanueva, F. (2011). A Composite Index for Benchmarking eHealth Deployment in European Acute Hospitals. European Commission - EUR 24825 EN $-2011$. 
Cooper, Z. (2011). In brief: Competition in the public sector: good for the goose, good for the gander? London: School of Economics and Political Science.

Cygańska, M. (2013). Benchmarking $w$ zarzadzaniu zaktadem opieki zdrowotnej. Warszawa: ABC a Wolters Kluwer business, http://www.zdrowie.abc.com.pl/ko/czytaj/-/artykul/ benchmarking-w-zarzadzaniu-zakladem-opieki-zdrowotnej (dostęp: 16.09.2013).

Gaynor, M., Town, R.J. (2012). Competition in Health Care Markets. Bristol: University of Bristol.

Goddard, J. (2014). The Fatal Bias: the Prevailing Managerial Bias Towards Cost Efficiency is Seriously Harmful to Corporate Performance. W: Winning Ideas. The Management Articles of the Year. London: Chartered Management Institute.

Hamel, G., Prahalad, C.K. (1999). Przewaga konkurencyjna jutra. Warszawa: Business Press. http://www.cmj.org.pl/ranking/wyniki_2014/wagi.php (dostęp: 8.03.2015).

http://www.cmj.org.pl/ranking/wyniki_2014/wyniki_koncowe.php (dostęp: 17.03.2015).

http://www.dagensmedicin.se (dostęp: 12.02.2015).

http://www.ltkalmar.se/politik/landstingets-reglemente (dostęp: 20.02.2015).

Informacja o wynikach kontroli (2014). Kontraktowanie świadczeń opieki zdrowotnej przez Narodowy Fundusz Zdrowia, nr. ewid. 15/2014/P12145/LKR, NIK - Delegatura w Krakowie. Kraków (luty).

Kanownik, G. (2013). Porównujmy. Menedżer Zdrowia (8).

Kanownik, G. (2014). Znaczenie benchmarkingu w kształtowaniu konkurencyjności szpitali. Zeszyty Naukowe Uniwersytetu Szczecińskiego (802): „Finanse. Rynki Finansowe. Ubezpieczenia”, nr 65. Szczecin: Wydawnictwo Naukowe Uniwersytetu Szczecińskiego.

Kanownik, G. (2015). SOS dla chorej ochrony zdrowia, www.serwiszoz.pl (dostęp: 15.04.2015).

Mierniki pomiaru konkurencyjności szpitali szwedzkich w oparciu o ranking „Bästa Sjukhuset 2014" (2015), http://www.dagensmedicin.se (dostęp: 12.02.2015).

Obłój, K. (2015). Model innowacyjny aż do bólu, www.ceo.cxo.pl/artykuly/25308_1/Model. innowacyjny.do.bolu.html, (dostęp: 25.04.2015).

Porter, M.E. (1985). The Competitive Advantage: Creating and Sustaining Superior Performance. New York: Free Press.

Porter, M.E. (2013). Winning Competitive Strategies In Today's Shifting Global Marketplace. Prezentacja: Nyenrode Business Universiteit, Amsterdam, 25.01.2007, http://www.isc.hbs. edu/pdf/20070125_Nyenrode_Health_Care_FINAL.pdf (dostęp: 31.07.2013).

Porter, M.E., Teisberg, E. (2005). Nowe zasady konkurencji w systemie opieki zdrowotnej. Harvard Business Review Polska 10(32).

Results from 2009 \& 2010 Tax (2013). Exempt Hospitals' Schedule H Community Benefit. Reporting, Ernst \& Young, April.

Stankiewicz, J.M. (2000). Istota i sposoby oceny konkurencyjności przedsiębiorstwa. Gospodarka Narodowa 8(7). 



\title{
Maciej Rogala ${ }^{1}$
}

\section{Analiza strategii rozwojowych największych prywatnych sieci medycznych w Polsce. Podobieństwa i różnice oraz wyzwania na przyszłość}

\begin{abstract}
Streszczenie
W artykule poddano analizie czynniki, jakie zadecydowały o rozwoju i sukcesie na rynku usług medycznych trzech największych sieciowych spółek medycznych działających w Polsce, takich jak Lux-Med, Medicover i Enel-Med. Porównano również podobieństwa i różnice w zakresie realizowanych strategii rynkowych $w$ ponad dwudziestoletniej historii funkcjonowania tych podmiotów, w tym rodzaje obieranych dotąd strategii oraz ich plany strategiczne na najbliższą przyszłość. W efekcie przeprowadzonych analiz zidentyfikowano podobieństwa i różnice w zakresie stosowanych strategii na początku funkcjonowania tych podmiotów oraz różnice, jakie nastąpiły w dalszych fazach ich rozwoju. Badania wykazały, iż o sukcesie rynkowym w przypadku każdej z trzech analizowanych spółek zadecydowały trzy takie same czynniki: główne grupy docelowe składające się z klientów korporacyjnych i indywidualnych, idące za tym źródła przychodów pochodzące w głównej mierze z rynku komercyjnego oraz charakter sieciowy tych spółek. Z kolei czynnikami różnicującymi ich rozwój są różne formy własności, sposoby i poziom finansowania oraz inwestycje w poszczególne segmenty usług zdrowotnych. Dodatkowo, czynnikiem różnicującym jest zakres prowadzonych na rynku przejęć innych podmiotów leczniczych i w efekcie odmienna struktura i idący za nią wachlarz oferowanych usług. Wykazano, iż omawiane firmy działające głównie w oparciu o abonamenty stały się liderami w zakresie konsolidacji prywatnego rynku usług medycznych w Polsce. Przeprowadzone analizy pozwoliły na sformułowanie kilku zasadniczych wniosków. Każda z omawianych spółek, mimo iż oparła swoje modele biznesowe o dywersyfikację portfela usług medycznych, realizowała i realizuje nadal inne podejście do rozwoju, co można zaobserwować w różnej formie organizacyjno-prawnej jako przedsiębiorstw,
\end{abstract}

1 Maciej Rogala - dr, Zakład Polityki Zdrowotnej i Zarządzania Instytutu Zdrowia Publicznego Wydziału Nauk o Zdrowiu UJ CM, ul. Grzegórzecka 20, 31-351 Kraków, e-mail: maciej.rogala@uj.edu.pl; ORCID: 0000-0001-8104-7617. 
ich strukturze oraz znacznym zróżnicowaniu w zakresie profilu inwestowania. Różny jest również stopień zaangażowania omawianych spółek w działalność szpitalną, co w świetle planowanych zmian systemowych związanych z tzw. siecią szpitali, czyli systemem podstawowego szpitalnego zabezpieczenia świadczeń opieki zdrowotnej (PSZ), może mieć określone konsekwencje dla dalszego rozwoju usług medycznych w ramach tego segmentu rynku.

Słowa kluczowe: analiza rynków ochrony zdrowia, strategia firmy, usługi biznesowe, zdrowie.

\title{
An Analysis of Development Strategies of the Largest Private Medical Chains in Poland. Similarities and Differences and Challenges for the Future
}

\begin{abstract}
The article analyses the factors that have determined the development and success of three largest medical chain companies operating in Poland, namely Lux-Med, Medicover and Enel-Med, on the medical services market. Similarities and differences between implemented market strategies, including the types of strategies chosen so far and their strategic plans for the nearest future, are compared within over twenty years of their operation. The analyses have identified similarities and differences between applied strategies at the beginning of their operation and differences that emerged in further phases of their development. The research has shown that three identical factors were behind the market success of each of the three examined companies: the main target groups consisting of corporate and individual clients, the resulting revenues primarily from the commercial market, and the chain nature of these companies. In turn, the factors differentiating their development include various forms of ownership, ways and levels of financing, and investment in particular segments of health services. In addition, the differentiating factor is the scope of acquisitions of other healthcare entities on the market and, consequently, a different structure and related range of services offered. It has been shown that the companies in question, relying mainly on subscriptions, have become leaders in consolidation of the private market for medical services in Poland. The analyses performed allowed some basic conclusions to be formulated. Each of the discussed companies, despite basing its business models on the diversification of the portfolio of medical services, has been implementing a different approach to development, which can be observed as various organisational and legal forms, structures and significant diversity of investment profiles. The degree of their involvement in hospital activities also varies, which - given the planned systemic changes related to the so-called hospital network, i.e the system of primary hospital-based security of healthcare services - may have specific consequences for the further development of medical services within this market segment.
\end{abstract}

Keywords: analysis of healthcare markets, firm strategy, business services, health.

\section{Wprowadzenie}

Transformacja polityczna i gospodarcza w 1989 roku pociągnęła za sobą wiele zmian, w tym uwolnienie rynku, tworząc nowy model gospodarczy nie 
oparty już na „dobru wspólnym”, ale na pojęciu zysku. W połowie 1992 roku nastąpiło odczuwalne ożywienie w gospodarce polskiej, a od 1994 roku to ożywienie przeszło $w$ trend o charakterze trwałych podstaw (Leszczyński, 2015). $\mathrm{Z}$ jednej strony zmiany systemowe ustroju gospodarczego, polegające m.in. na uwolnieniu rynku i wprowadzeniu idącej za tym tzw. gospodarki wolnorynkowej (Bałtowski, Miszewski, 2015; Gilejko, 2009, s. 17-21; Geise, Oczki i Piotrowski, red., 2016), a z drugiej strony brak tego typu podmiotów doprowadzity w pierwszej połowie lat 90 . XX wieku do utworzenia na polskim rynku spółek, które przez cały okres swojego funkcjonowania przeszły wiele zmian i należą do grupy największych podmiotów medycznych w Polsce, opartych o strukturę sieciową i sprzedaż abonamentową. Mowa tutaj o trzech podmiotach: Lux-Med, Medicover i Enel-Med. Ich wejście na rynek w latach 90. XX wieku wypełniło z jednej strony lukę związaną z brakiem prywatnych przychodni, gdzie pacjent może czuć się klientem, a nie tylko petentem, a z drugiej strony zaczęły zastępować funkcjonujące w czasach PRL spółdzielnie lekarskie (zob. Magowska). I tak w 1993 roku została założona spółka Lux-Med oraz EnelMed, rok później w 1994 roku Medicover.

W artykule poddano analizie występujące podobieństwa i różnice w ramach strategii rozwoju tych trzech centrów medycznych, działających nieprzerwanie od pierwszej połowy lat 90 . XX wieku do dnia dzisiejszego, które są zaliczane do największych spółek medycznych pod względem wysokości przychodów, liczby pacjentów i placówek na terenie całego kraju. Istotnym elementem tego opracowania jest również analiza wyzwań i szans płynących z otoczenia konkurencyjnego, które mogą doprowadzić do dalszego rozwoju tych spółek, jak również barier czy zagrożeń dla dalszego ich funkcjonowania w dotychczasowym zakresie, ze względu na mające wejść niedługo w życie zmiany o charakterze systemowym w sektorze ochrony zdrowia.

Głównym celem pracy była analiza czynników, jakie zadecydowały o rozwoju i sukcesie na rynku polskim usług medycznych trzech wiodących spółek sieciowych Lux-Medu, Medicoveru i Enel-Medu, których głównym źródłem przychodów jest opieka abonamentowa dla firm i klientów indywidualnych. W tym zakresie, przedmiotem badania były zasoby wewnętrzne, jakie posiadają i obecnie dysponują omawiane spółki, jak również uwarunkowania zewnętrzne, płynące $\mathrm{z}$ otoczenia bliższego i dalszego, determinujące lub znacząco wpływające na podejmowane działania o charakterze strategicznym. Analizie poddano również podobieństwa i różnice w zakresie realizowanych strategii rynkowych w ponad dwudziestoletniej historii funkcjonowania tych podmiotów, w tym rodzaje obieranych dotąd strategii, jak i plany strategiczne na najbliższą przyszłość. 


\section{Enel-Med}

Enel-Med to największa rodzinna medyczna firma w Polsce i trzecia pod względem przychodów firma abonamentowa w Polsce założona w 1993 roku przez małżeństwo Adama i Annę Rozwadowskich, absolwentów Wydziału Elektrycznego Politechniki Gdańskiej, działająca na początku jako centrum stomatologiczne, dysponujące 10 gabinetami, zatrudniające 25 lekarzy dentystów oraz 25 asystentek (zob. Enel-Med: historia stomatologii). W roku 1998 Enel-Med rozszerzył swoją działalność, uruchamiając Szpital Zacisze w Warszawie z dwiema salami operacyjnymi i 19 łóżkami oraz stworzył program opieki abonamentowej EnelCare. W roku 2003 Enel-Med, jako pierwsze centrum medyczne w Polsce, wprowadziło do swojej oferty teleradiologię, a rok później system ubezpieczeń zdrowotnych Medi-Care. W latach 2004-2010 firma zaczęła się przeistaczać z firmy lokalnej w ogólnopolską sieć medyczną, otwierając oddziały zarówno w Warszawie, jak i innych największych miastach Polski w: Łodzi, Krakowie, Wrocławiu i Poznaniu. Cechą charakterystyczną wyróżniającą Enel-Med było zakładanie wszystkich centrów medycznych w dużych galeriach handlowych (zob. Prezentacja dla inwestorów: Enel-Med idzie na giełdę. Perspektywy rozwoju i strategia). Punktem zwrotnym dla rozwoju firmy był 2011 rok, kiedy jej właściciele podjęli decyzję o wejściu spółki na giełdę, głównym tego powodem była chęć zdobycia zewnętrznych środków finansowych na dalszy rozwój. Pierwsze próby wejścia na giełdę spółka podjęła już wcześniej, ponieważ w 2006 roku - zrezygnowała z nich jednak z uwagi na możliwość wzięcia kredytów bankowych, a kolejne próby pozyskania funduszy nastąpiły rok później (zob. PAP, Enel-Med rezygnuje z wejścia na GPW w 2006 roku. Puls biznesu, 2006). Wówczas próbowano różnych koncepcji dalszego rozwoju spółki, takich jak: Giełda Papierów Wartościowych, współpraca $\mathrm{z}$ firmą ubezpieczeniową, fuzja $\mathrm{z}$ innym centrum medycznym lub dokapitalizowanie przez fundusz inwestycyjny (zob. MB, Enel-Med szuka wyjść awaryjnych, Puls Biznesu 2007). Kilka lat później firma powróciła do pierwszej koncepcji - w liczącym ponad 300 stron prospekcie emisyjnym, przygotowanym dla potencjalnych akcjonariuszy, zawarto m.in. główne cele strategiczne, przyświecające wejściu na GPW (Prospekt emisyjny Enel-Med). Spółka dzięki wejściu na giełdę zaplanowała: budowę i wyposażenie nowego specjalistycznego szpitala na terenie Warszawy (szpital przy Al. Solidarności), rozbudowę sieci przychodni wieloprofilowych i stomatologii, zwiększenie potencjału w segmencie diagnostyki obrazowej i teleradiologii, inwestycję w systemy i oprogramowanie IT oraz usprawnienie efektywności operacyjnej. Enel-Med założył, iż te plany zrealizuje w latach 2011-2013 i potrzebuje na nie dokładnie 74,2 mln 
zł, a z emisji akcji chciałby uzyskać 51,5 mln zł i przeznaczyć je w całości na te inwestycje. Szczegółowa opisana strategia dalszego rozwoju spółki, zaznaczenie jej wysokiej pozycji rynkowej (3 pozycja pod względem przychodów) oraz skala dynamiki rynku usług medycznych w Polsce spowodowały, iż ostatecznie spółka pozyskała z giełdy kwotę $35,5 \mathrm{mln}$ zł. Inwestorom przydzielono łącznie 7.100.000 walorów, w ramach których inwestorzy instytucjonalni objęli 5.600.000 akcji, a inwestorzy indywidualni 1.500 .000 akcji, przy cenie emisyjnej 5,00 zł. Co ciekawe, zgłoszony przez inwestorów popyt znacznie przewyższył liczbę oferowanych walorów, gdyż złożono zapisy na 7.541.063 akcji (a sprzedano tylko 7,100.00), a zatem redukcja zapisów wyniosła ponad 20\%, co może tłumaczyć przynajmniej po części niższą sumę niż pierwotnie oczekiwano, jaką spółka otrzymała z giełdy w zamian za sprzedaż akcji. Co istotne, w rozkładzie akcjonariatu oraz po samym debiucie, a także w dalszym ciągu większościowe udziały pozostają w rękach dotychczasowych właścicieli Enel-Medu, czyli rodziny Rozwadowskich (Adama i Anny oraz ich synów - Jacka i Bartosza), którzy skupiają łącznie blisko $70 \%$ akcji, a pozostała część jest podzielona pomiędzy Generali OFE, OFE PZU „Złota Jesień” (mają udziały powyżej $5 \%$ ) oraz tzw. pozostałych akcjonariuszy (którzy mają udziały poniżej 5\%). Według deklaracji Adama Rozwadowskiego w najbliższych latach nie dojdzie do sprzedaży akcji rodzinnych i tym samo wejścia nowych akcjonariuszy (zob. Informacje korporacyjne Enel-Med [a] i [b]; Stowarzyszenie Inwestorów Indywidualnych: czat inwestorski).

Wejście spółki na giełdę dało jej nowe środki oraz impuls do dalszego rozwoju - wszystkie założone inwestycje zostały zrealizowane, a w 2012 roku otwarto drugą placówkę szpitalną Szpital Centrum. Obecnie, tak jak od lat, Enel-Med w swoim modelu biznesowym wyróżnia przede wszystkim sprzedaż abonamentów oraz usług komercyjnych i ubezpieczeniowych, które stanowią główne źródła przychodów: odpowiednio $57 \%$ oraz $15 \%$ przychodów; kolejnymi źródłami dochodów są stomatologia i szpitale: po odpowiednio 7\% i 5\% i właśnie w tych obszarach firma planuje dalszy rozwój infrastruktury. Przychody z NFZ w 2016 roku plasowały się na poziomie 3,3\%. Enel-Med rezygnował z rozwijania segmentu diagnostyki obrazowej, sprzedając ją Lux-Medowi. Choć Enel-Med ograniczył w ten sposób działalność diagnostyczną, to nie zrezygnował z niej całkowicie i rozwija ją już nie jako osobną markę, ale w synergii $\mathrm{z}$ istniejącymi placówkami, w tym z dwoma szpitalami. W ostatnim czasie spółka zaczęła wchodzić $\mathrm{w}$ nowe segmenty rynkowe, co jest związane $\mathrm{z}$ otwarciem się na usługi opieki długoterminowej dla osób starszych poprzez nabycie $65 \%$ udziałów w spółce Jovimed Ośrodek Opiekuńczo-Rehabilitacyjny sp. z o.o., który jest zlokalizowany w Ksawerowie pod Łodzią oraz otwarcie centrum 
medycyny estetycznej ESTELL, a także uruchomienie dwóch Centrów Ortopedii i Rehabilitacji ENEL-SPORT w Warszawie - nowych marek biznesowych Spółki (zob. Informacje korporacyjne Enel-Med [c], [d], [e], [f]).

\section{Medicover}

To druga pod względem przychodów firma medyczna w kraju o profilu abonamentowym, założona w 1994 roku, początkowo nazywana ABC Medicover, powstała dzięki zaangażowaniu szwedzkiego przedsiębiorcy Bengta Beckmanna, który wraz z żoną przyjechał do Polski i obserwując niski poziom opieki zdrowotnej (doświadczył tego w odniesieniu do chorujących rodziców swojej żony) wspólnie z przyjaciółmi podjął decyzję o założeniu nowej firmy, której pierwsza przychodnia powstała w 1995 roku w Warszawie. Bengt Beckmann, zanim założył Medicover, rozwinął w Kenii biznesowe usługi medyczne o nazwie Africa Air Rescue (AAR), będące rodzajem pogotowia lotniczego. W rozwój ABC Medicover zainwestował Jonasaf Jochnick, założyciel kosmetycznego koncernu Oriflame. Od początku ABC Medicover był oparty na nowym wówczas w Polsce modelu biznesowym opieki medycznej dla firm, gdzie duży nacisk kładziono na jakość usług oraz indywidualne podejście do pacjenta. W pierwszym okresie działalności ABC Medicover pozyskał w latach 1993-1995 międzynarodowego partnera strategicznego w postaci organizacji Community Health Plan (CHP) z USA, założonej przez Warena Palleya. Lata 1996-1999 to czas ekspansji Medicovera w Polsce, kiedy w sześciu miastach kraju otworzył swoje przychodnie oraz rozpoczął działalność w innych krajach Europy Środkowej - na Węgrzech, w Estonii, Rumunii i Czechach, inwestując m.in. w sieć diagnostyki laboratoryjnej. W 2004 roku Medicover jako pierwsza grupa medyczna w Polsce wprowadziła elektroniczną dokumentację pacjenta, rok później możliwość rejestracji on-line, a od 2007 roku udostępnia on-line wyniki badań medycznych i porady oraz zalecenia prozdrowotne. W latach 2000-2010 Grupa Medicover stworzyła strukturę dywizjonalną, wydzielając dwie główne dywizje: Medicover z siecią przychodni ambulatoryjnych i szpitalem oraz Synevo z siecią diagnostyki laboratoryjnej. W roku 2007 spółka powołała do życia fundację, której celem jest budowanie świadomości na temat roli zdrowia oraz kondycji fizycznej i psychicznej. Przełomowym punktem w rozwoju firmy była budowa największego prywatnego szpitala w Polsce, zakonczona w 2009 roku, o powierzchni 16 tys. m kw., z 180 łóżkami, dysponującego 5 blokami operacyjnymi, 8 klinikami oraz dwoma centrami specjalistycznymi: diagnostycznym i konsultacyjnym. W 2014 roku Medicover dokupił 2,5 hektara bezpośrednio sąsiadującej ze szpitalem działki w celu dalszej rozbudo- 
wy. W maju 2017 roku firma ogłosiła informacje o wejściu na giełdę papierów wartościowych w Szwecji, a większościowym akcjonariuszem pozostał Jonasaf Jochnick. Środki uzyskane z giełdy mają zostać spożytkowane na spłatę zadłużenia, co pozwoli spółce na zaciągnięcia długu na kwotę $250 \mathrm{mln}$ euro, który ma być wykorzystany na inwestycje i przejęcia (Wierzchowska, 2017; Health Care Business International; Raport z działalności Fundacji Medicover 2015; Ragus, 2014).

Obecnie Medicover to międzynarodowa organizacja nastawiona na działalność biznesową w obszarze medycyny działająca głównie w Polsce, Niemczech, Rumunii, na Ukrainie oraz na innych rynkach Europy Zachodniej, Środkowej oraz Wschodniej. W 2016 roku cała grupa Medicover wygenerowała przychody w wysokości blisko $500 \mathrm{mln}$ euro i zysk netto (EBITDA) na poziomie $46 \mathrm{mln}$ euro. Jeśli porównamy te przychody z 2006 rokiem, czyli sprzed ponad 10 lat wcześniej, ich wartość osiągała wówczas kwotę $75 \mathrm{mln}$ euro, a zatem podwoiła się o $600 \%$. Natomiast $45 \%$ przychodów grupy pochodzi z działalności w Polsce, czyli jest to wartość około $990 \mathrm{mln}$ zł. Przez ostatnie lata spółka dokonała wiele akwizycji na rynku, dzięki czemu jej działalność jest mocno zdywersyfikowana, choć w znacznej mierze opiera się na sprzedaży abonamentów dla firm i klientów indywidualnych oraz usługach diagnostyki laboratoryjnej. Zdywersyfikowana działalność Medicovera jest efektem przeprowadzonych akwizycji, w wyniku których w ramach grupy znalazły się m.in. domy opieki nad osobami starszymi, działające w dużych miastach Polski w ramach spółki Care Experts, Centrum Medyczne Damiana z 5 przychodniami i własnym szpitalem na terenie Warszawy, sieć centrów leczenia niepłodności InviMed w pięciu miastach, 10 placówek ambulatoryjnych na terenie kraju pod marką MediPartner, apteki działające przy wybranych centrach medycznych Medicover, Medicover Försäkrings z ofertą pakietów ubezpieczeniowych oraz kliniki Rehasport Clinic, zajmujące się leczeniem narządu ruchu $-\mathrm{z}$ akredytacją FIFA Medical Centre of Excellence. W roku 2013 spółka przejęła sieć placówek stomatologicznych Dantex-Medz czterema centrami własnymi w Warszawie oraz siecią 79 partnerów. W 2015 roku Medicover przejął również Oddział Kardiochirurgii Allenort, który od 2012 roku funkcjonuje w Szpitalu Medicover oraz Centrum Kardiologii Allenort w Warszawie. W strategii dalszego rozwoju spółka stawia na rozwój diagnostyki, centrów dentystycznych i płodności (zob.: MM, Medicover przejmuje Dantex, Puls Medycyny, wrzesień 2011; Medicover.com, oficjalna strona Grupy Medicover; Portal Zdrowie ABC, Medicover kupił spółkę Allenort, luty 2015; Scandinavian-Polish Chamber of Commerce, Medicover Poland: Debiut Medicover AB na Giełdzie w Sztokholmie; Medicover.com, oficjalna strona Grupy Medicover; Dyskusja.biz, Jest przeciek. PZU będzie 
kontynuować przejęcia placówek medycznych, marzec 2016; GoWork, Historia Medicover; Urbanity.pl, Szpital Medicover).

\section{Lux-Med}

Lux-Med to największa grupa medyczna w Polsce pod względem przychodów. Firma powstała w 1992 roku. Została założona przez dr n. med. Wojciecha Pawłowskiego, od 1994 roku prezesa zarządu, a pierwszy pacjent został przyjęty w placówce przy ul. Racławickiej w Warszawie w 1993 roku. Lux-Med jako jedno z pierwszych prywatnych centrów medycznych w Polsce postawił od początku na ściągnięcie do przychodni wysokokwalifikowanych lekarzy, a z końcem lat 90 . XX wieku na zapewnienie pacjentom nowoczesnego sprzętu medycznego, jak: cyfrowy rentgen, tomograf komputerowy czy rezonans, które obecnie są standardem, ale wówczas były absolutnym novum. Lux-Med szybko do oferty wprowadził opiekę abonamentową dla przedsiębiorstw i jako pierwsza firma medyczna w kraju powołał do życia Radę Naukową złożoną z 35 profesorów i doktorów habilitowanych, autorytetów z różnych dziedzin medycyny. W 2002 roku zmieniła się struktura udziałów w firmie, ponieważ pojawił się nowy większościowy udziałowiec, z ponad 70\% udziałów, Lux-Med Holdings związany z funduszem inwestycyjnym CWC Central European Investment Fund, dzięki czemu firma mogła - i taki był cel biznesowy - rozbudowywać się w ogólnopolską sieć medyczną.

Przełomowy moment w historii rozwoju firmy rozpoczął się jednak kilka lat później, kiedy Lux-Med przeszedł w ręce innego właściciela - funduszu private equity MidEuropa Partners z siedzibą w Londynie, który kupił sieć, składającą się z 14 przychodni, zlokalizowanych w największych miastach Polski. Wkrótce okazało się, że to początek niespotykanej dotychczas w naszym kraju skali przejęć przez jeden prywatny podmiot - inwestora finansowego w obszarze usług medycznych. W krótkim czasie, w latach 2007-2008, MidEuropa Partners przejął również Medycyną Rodzinną, Centrum Medyczne LIM i Promedis. Jako kolejną po Lux-Medzie spółkę, fundusz inwestycyjny private equity przejął Medycynę Rodzinną z siecią obejmującą 16 placówek, powstałą w 1998 roku z inicjatywy grupy warszawskich lekarzy, obsługujących pacjentów podstawowej opieki zdrowotnej, abonamentowych oraz z polisami ubezpieczeń zdrowotnych. Następnie doszło do przejęcia Promedisu, powstałego w 1998 roku, początkowo działającego jako przychodnia specjalistyczna - Centrum Medycyny Rehabilitacji MEDAR, będąca placówką przyzakładową firmy Impel, które również przekształciło się z czasem w ogólnopolską sieć placówek, oferującą opiekę abonamentową. Ostatnim dużym wtedy przejęciem 
był zakup centrum medycznego LIM. LIM powstało w 1991 roku z inicjatywy grupy lekarzy i pielęgniarek pracujących w zakładowej służby zdrowia Polskich Linii Lotniczych LOT, którzy założyli spółdzielnię lekarską, rozwiniętą następnie w sieć 17 placówek medycznych w różnych miastach Polski, oferujących głównie opiekę medyczną dla firm. Dzięki tym transakcjom MidEuropa Partners stworzył największą grupę medyczną w Polsce i jednocześnie rozpoczął proces integracji tych spółek, które w 2009 roku zaczęły działać w ramach jednego podmiotu Lux-Med Sp. z o.o., tworząc Grupę Lux-Med. Integrację przeprowadzono pod hasłem: „Kilka tradycji - jeden zdrowy cel”, wykorzystując doświadczenia i rozwiązania każdej ze spółek dla wspólnego rozwoju całej grupy, która już w 2009 roku posiadała 69 placówek własnych, 26 przyzakładowych, około 1000 współpracujących poradni medycznych w całej Polsce i około 960 tys. pacjentów. W roku 2010 Lux-Med zaczął wchodzić we własny segment usług szpitalnych, otwierając na warszawskim Ursynowie szpital posiadający 12 łóżek, dwie sale operacyjne i 7 gabinetów specjalistycznych, a inwestycja zamknęła się w kwocie około 20 mln zł (zob. Twoje Zdrowie, zima 2003; Blisko Zdrowia, listopad 2009; Interia Biznes, wrzesień 2004; Rulkiewicz).

Jak okazało się kilka lat później konsolidacja rynku na bazie przejętych i zintegrowanych spółek doprowadziła do najdroższej w Polsce transakcji w zakresie przejęć, jaka miała miejsce w grudniu 2012 roku o wartości 400 mln euro (1,625 mld zł), w ramach której dotychczasowy właściciel MidEuropa Partners sprzedał Lux-Med nowemu inwestorowi, tym razem branżowemu z obszaru medycyny i ochrony zdrowia (w odróżnieniu od MidEuropa Partners, który był inwestorem finansowym), międzynarodowej grupie Bupa z siedzibą w Wielkiej Brytanii. Po zmianie właściciela, oprócz zarządu, wszyscy pracownicy Lux-Medu pozostali w nim nadal zatrudnieni. Transakcja była jednoznaczna z wejściem grupy Bupa na nowy polski rynek - spółki z dużym doświadczeniem w zakresie działalności międzynarodowej, działającej w branży opieki zdrowotnej od lat i obsługującej obecnie 22 mln klientów na całym świecie. W 2011 roku, czyli w roku dokonania akwizycji Lux-Medu, Bupa osiągnęła przychody w wysokości 40,7 mld zł oraz zysk w wysokości 2,8 mld zł, przy obecnym zatrudnieniu ponad 70 tys. osób (zob. Interia Biznes, Bupa przejmie Lux-Med; Bupa, oficjalna strona Grupy Bupa; Gwozdowska, 2009).

Zmiana właściciela pociągnęła za sobą kolejne przejęcia i dalszy rozwój Lux-Medu na rynku. W roku 2012 spółka przejęła Endoterapię z placówkami w Warszawie i Łodzi specjalizującymi się w zakresie badań i zabiegów endoskopowych w warunkach szpitalnych, a w 2013 roku kupiła ośrodek szpitalny, specjalizujący się w leczeniu dolegliwości i schorzeń narządu ruchu - Carolina Medical Center w Warszawie z certyfikatem FIFA Medical Clinic of Excel- 
lence, składający się z 36-łóżkowego szpitala, działającego w 90\% w ramach fee for service, całodobowego ambulatorium urazowego, polikliniki i centrum rehabilitacyjnego. Łącznie w latach 2008-2015 Lux-Med dokonał 23 akwizycji spółek o zróżnicowanym profilu funkcjonowania, w tym spółki diagnostyczne - Centrum Medyczne Diagnostyka, Diagnostic-Med, Scanlab, Tomograf, TK Medyk oraz sieci ambulatoryjne MegaMed, Medicor i Centrum Zdrowia Medycyna. W roku 2015 Lux-Med przejął spółkę EuroClinic z Krakowa świadczącą usługi z zakresu diagnostyki obrazowej, rehabilitacji i ambulatoryjnej opieki specjalistycznej. W roku 2016 Lux-Med zakupił spółkę Magodent i dzięki tej transakcji wszedł na rynek usług medycznych szpitalnych o profilu onkologicznym m.in. z dwoma szpitalami onkologicznymi na terenie Warszawy: Szpitalem św. Wincentego i Szpitalem Fieldorfa. W tym samym roku Lux-Med przejął m.in. sieć pięciu specjalistycznych placówek Centrum Stomatologicznego EURODENTAL zlokalizowanych na terenie Warszawy i okolic (zob. Portal Zdrowie.abc, 23 akwizycje w 8 lat. Lux-Med przejmuje EuroClinic, październik 2015).

Najnowszym projektem Lux-Medu było otwarcie w marcu 2017 roku szpitala onkologicznego Magodent na warszawskim Żoliborzu u zbiegu ulic Elbląskiej i Szamockiej. W placówce znajduje się łącznie 178 łóżek oraz 38 stanowisk chemioterapii dziennej. Nowy szpital Grupy Lux-Med oferuje pacjentom kompleksową diagnostykę i leczenie chorób onkologicznych. Nowa placówka stała się już ósmym ośrodkiem hospitalizacyjnym Grupy Lux-Med i trzecim specjalizującym się w onkologii, działającym w ramach marki Magodent (zob. Portal Grupy Lux-Med, grudzień 2013; Parkiet, Kolejne przejęcie Lux-Medu; Portal Zdrowie.abc, Grupa Lux-Med: przejęcie sieci medycznej Medicor z Rzeszowa, kwiecień 2015; Portal Magodent).

\section{Analiza porównawcza}

Dla celów tego opracowania poddano analizie podobieństwa i różnice w ramach strategii rozwoju największych spółek medycznych: Lux-Medu, Medicovera i Enel-Medu od momentu ich powstania aż po dzień dzisiejszy, działających w strukturze sieciowej wyodrębnionych pod względem wysokości przychodów, liczby pacjentów i placówek na terenie całego kraju. Głównym celem pracy była analiza czynników, jakie zadecydowały o rozwoju i sukcesie na rynku usług medycznych tych trzech wiodących spółek sieciowych, których głównym źródłem przychodów są abonamenty dla firm i klientów indywidualnych. W tym zakresie, przedmiotem badania były zasoby wewnętrzne, jakimi dysponowały i dysponują omawiane spółki, jak również uwarunkowania 
zewnętrzne, płynące z otoczenia bliższego i dalszego, determinujące lub znacząco wpływające na podejmowane działania o charakterze strategicznym.

Analizie poddano również podobieństwa i różnice w zakresie realizowanych strategii rynkowych w ponad dwudziestoletniej historii funkcjonowania tych podmiotów, w tym zarówno rodzaje obieranych dotąd strategii, jak i plany strategiczne na najbliższą przyszłość, związane ze zmianami o charakterze systemowym. W pracy skupiono się na analizie typu desk research, wykorzystując publicznie dostępne informacje na temat tych spółek, jak również wystąpiono o dane o charakterze pierwotnym, zwracając się do spółek ze szczegółowymi pytaniami badawczymi w celu uzupełnienia posiadanych już informacji. Przeanalizowano również raporty, artykuły i opracowania branżowe oraz obecnie obowiązujące i mające wejść w życie akty prawne na mocy ustawy i inne przepisy warunkujące funkcjonowanie na rynku tych podmiotów, w tym w zakresie możliwości przyszłego kontraktowania świadczeń zdrowotnych z płatnikiem publicznym, czyli NFZ.

Poddane badaniu spółki to trzy największe firmy abonamentowe w Polsce pod względem liczby klientów, wysokości przychodów i liczby placówek medycznych. Pierwsze miejsce w tej trójce zajmuje Lux-Med, z przychodami w 2016 roku o wartości około 1,17 mld zł, drugi w kolejności to Medicover, który zamknął rok obrotowy z kwotą około 990 mln zł, a trzeci Enel-Med z przychodami o wartości $271 \mathrm{mln}$ zł. Analizując strukturę przychodów tych spółek należy zaznaczyć, iż w każdej z omawianych sieci dominującą pozycję zajmują przychody z abonamentów, pochodzące głównie z opłat ryczałtowych od firm oraz klientów indywidualnych i stanowią około $70 \%$ wszystkich przychodów. Pozostałe przychody w trzech omawianych spółkach to usługi szpitalne, stomatologia, diagnostyka, fee for service oraz usługi w ramach NFZ. Środki finansowe od płatnika publicznego, jakim jest wspomniany NFZ, stanowią od kilku do kilkunastu procent przychodów i tak w przypadku Enel-Medu - około $3,3 \%$, Medicoveru - około 5\%, a Lux-Medu - około 12\%. Analizując omawiane spółki pod kątem liczby pacjentów warto zauważyć, iż łącznie liczba obsługiwanych przez te podmioty pacjentów przekroczyła 3,5 mln osób i powoli zbliża się do $10 \%$ populacji Polski, a liczba firm objętych stałą opieką medyczną sięga kilkunastu tysięcy. I tak Lux-Med posiada 1 mln klientów abonamentowych, przy łącznej liczbie klientów 1,8 mln. W przypadku Medicovera liczba klientów przekroczyła $1 \mathrm{mln}$ zł, obsługuje on ponad 8,5 tys. firm i 660 tys. indywidualnych pacjentów, a Enel-Med ma ponad 700 tys. klientów i w portfelu 3,7 tysiąca firm.

W toku analizy zidentyfikowano następujące rozwiązania strategiczne w każdej ze spółek oparte o: 
- dywersyfikację (działalność w różnych segmentach medycyny, szeroki wachlarz pakietów dostosowanych do różnych grup docelowych klientów),

- komplementarność (uzupełnianie się segmentów - diagnostyka i zabiegi szpitalne, profilaktyka i konsultacje, oferty dla rodzin i osób indywidualnych),

- kompleksowość (profilaktyka, POZ, AOS, zabiegi planowe, rehabilitacja, abonamenty dla firm i klientów indywidualnych; całościowy cykl leczenia).

Model biznesowy oparty na trzech powyższych elementach pozwala omawianym spółkom na bezpieczeństwo finansowe - jeśli jeden segment przynosi mniejsze zyski w wyniku, np.: nasycenia rynku i w efekcie załamania się popytu, zmian demograficznych, zjawisk epidemiologicznych, zmian w trendach, czy przepisów prawa, to spółki mają możliwość rozwoju i inwestowania w inny segment. Jednocześnie model ten daje możliwość elastycznego dopasowania się do aktualnych wymagań pacjentów, a kompleksowość i komplementarność pozwalają na dopasowanie oferty usług do różnych grup odbiorców w zależności od ich preferencji i potrzeb.

W ramach przeprowadzonej analizy wyodrębniono podobieństwa pomiędzy analizowanymi trzema sieciami, które obejmują:

- dopasowanie ich do zapotrzebowania rynkowego - zastosowano szeroką paletę abonamentów dla firm i klientów indywidualnych elastycznie dopasowywanych do potrzeb klienta;

- koncentrację na kliencie korporacyjnym - każda ze spółek główną część przychodów - od początku swojego istnienia - opiera na świadczeniach opieki medycznej o charakterze abonamentowym w ramach comiesięcznego ryczałtu;

- rozwój usług dla klientów indywidualnych - omawiane podmioty od lat, obok oferty dla firm, rozwijają różne programy opieki profilaktycznej i leczniczej dla klientów indywidualnych, w tym pozycjonowanych dla dzieci, dorosłych, osób starszych i całych rodzin w ramach pakietów medycznych, ubezpieczeń oraz fee for service;

- wysoką jakość obsługi klienta i świadczonych usług - deklarowaną, ale również sprawdzaną w badaniach jakości, szczególnie w badaniach satysfakcji pacjenta;

- zbliżoną wielkość i profil placówek - zastosowano zbliżony model wnętrz, funkcjonalności i zakresu usług w każdej z przychodni;

- rozwój organiczny poprzez stałe poszerzanie liczby placówek - cechuje każdą ze spółek, choć w różnym stopniu, które poprzez zwiększenie własnego potencjału szukają ciągle nowych możliwości dalszego wzrostu. 
Analiza dotychczasowej działalności omawianych spółek pozwoliła na wyodrębnienie różnic determinujących perspektywy rozwoju każdej z nich, na co składają się:

- stopień i możliwości dalszego zaangażowania finansowego - należy pamiętać, że za grupą Lux-Med i Medicover stoi duży międzynarodowy kapitał, a Enel-Med jest firmą rodzinną, choć od pewnego czasu 30\% udziałów spółki jest skupionych w rękach podmiotów zewnętrznych. Największe możliwości dalszego zaangażowania wydaje się mieć Lux-Med, choć niedawne wejście na giełdę Medicovera może świadczyć z jednej strony o silnej potrzebie pozyskania nowych środków pieniężnych, ale z drugiej - co wynika z wypowiedzi władz spółki - również o dalszych planowanych inwestycjach, w tym akwizycjach, które z pewnością mogłyby dać perspektywy do dalszego rozwoju i wpłynęłyby na zwiększenie przychodów ze sprzedaży. Najmniejsze szanse w tej trójce ma raczej centrum Enel-Med, którego większościowy pakiet akcji ma nadal rodzina Rozwadowskich, a znaczący dopływ środków zewnętrznych musiałby się wiązać, ze sprzedażą własnych akcji, na co według założycieli spółki w najbliższych latach się nie zanosi;

- przejęcia - powiększają portfel pacjentów i dają możliwości dalszego rozwijania spółek, ale są bezpośrednio związane z pulą posiadanych na ten cel środków. Najbardziej aktywny na tym polu jest Lux-Med, któremu- patrząc na liczbę inwestycji i ich zasięg - ustępuje centrum Medicover, także aktywne w tym obszarze. Z kolei Enel-Med praktycznie nie uczestniczy na razie w tym procesie, choć nie wyklucza w przyszłości tej drogi dalszego rozwoju, czego początkiem może być zakup $65 \%$ udziałów w jednej ze spółek prowadzących ośrodek opiekuńczo-rehabilitacyjny;

- zróżnicowanie w zakresie profilu i rozmiarów szpitali - jako jedyny z analizowanej trójki Medicover posiada duży wieloprofilowy szpital w jednym miejscu, spółka zamierza dalej się rozwijać. Choć nie można stwierdzić, czy Lux-Med, który niedawno otworzył szpital o podobnej liczbie łóżek, nie rozwija w sposób aktywny tego segmentu, to jednak po dotychczasowych inwestycjach i przejęciach widać, że są to raczej jednoprofilowe szpitale, jak: Magodent, Endoterapia czy Carolina Center lub o małej liczbie łóżek, jak Szpital Puławska. Enel-Med przed kilkoma lata zakończył inwestycję w drugą jednostkę leczniczą, ale są to placówki nieduże - od 20 i 30 lóżek. Porównując stopień, zakres i liczbę placówek szpitalnych i ambulatoryjnych widać zdecydowanie większe zaangażowanie każdej ze spółek w rozwój przychodni niż w segment szpitalnictwa, choć ta propozycja zaczyna się powoli zmieniać;

- struktura spółek - Enel-Med stanowi w miarę jednolitą strukturę, natomiast Medicover, a jeszcze w większym stopniu Lux-Med, to grupa wielu spółek 
o różnym standardzie jakościowym i cenowym z wieloma markami, związanymi z różnymi segmentami usług zdrowotnych, co z jednej strony daje przewagę konkurencyjności w postaci kompleksowości i komplementarności, ale z drugiej może stanowić naturalny problem w dotarciu do różnych grup odbiorców, którzy mogą mieć trudności z wyborem optymalnej dla siebie oferty spośród różnych marek;

- model zarządzania i przywództwa - o ile częścią wspólną dla trzech analizowanych spółek będzie wysoka dbałość o wskaźniki efektywności ekonomicznej, o tyle elementami różnicującymi omawiane podmioty będą różne modele przywództwa i związane z nimi sposoby prowadzenia firmy. Inaczej bowiem zarządza się firmą rodzinną, a inaczej spółką, będącą częścią międzynarodowej organizacji, która narzuca z jednej strony wskaźniki ekonomiczne, a z drugiej - sformalizowane procedury organizacyjne, w tym kulturę organizacyjną, opartą na raportowaniu o wynikach do centrali firmy, które w przypadku Lux-Medu i Medicoveru są poza Polską. Modele te w ostatnich latach zaczęły się zbliżać wraz wejściem Enel-Medu na giełdę i koniecznością liczenia się z wolą akcjonariuszy, którzy choć nie mają bezpośredniego wpływu na zarządzanie spółką, to mogą wyrażać swoje zadowolenie lub jego brak na decyzje władz spółki w formie zakupu lub sprzedaży akcji;

- polityka informacyjna - jest niewątpliwie elementem różnicującym każdą ze spółek i choć każda z nich w komunikacji z rynkiem stara się pokazać swoje mocne strony, aby przyciągnąć klientów (co stanowi oczywiste podobieństwo), to jednak różnice w formie prawnej spółek są widoczne w zakresie przekazywanych informacji, które mogą być analizowane przez różne grupy interesu i tzw. otoczenie rynkowe. Najbardziej przejrzystą politykę w tym zakresie prowadzi Enel-Med. Z racji tego, że jest on podmiotem notowanym na GPW pełna otwartość informacyjna jest dla tej spółki naturalnym wymogiem. Z Medicoverem jest sytuacja nieco bardziej skomplikowana, bo choć cała grupa Medicover, jako spółka akcyjna na giełdzie w Szwecji, jest zobligowana do przekazywania ogólnej informacji korporacyjnej o całej grupie, to już Medicover Polska jako jedna ze spółek zależnych tej grupy jest spółką z o.o. i nie ma obowiązku publikowania np. raportów finansowych ze swojej wydzielonej działalności. Z kolei Lux-Med jako spółka $z$ o.o. na giełdzie nie figuruje i stąd też informacje przekazywane na zewnątrz poddaje biznesowej selekcji, nie podając np. relacji pomiędzy przychodami a kosztami (informuje np. tylko o wzroście przychodów), stąd też nie wiadomo jaka jest jej rzeczywista sytuacja finansowa w danym roku obrotowym. 
W pracy skupiono się również na analizie wyzwań i zagrożeń płynących z otoczenia dalszego związanych ze zmianami systemowymi, które mogą wpłynąć na dalszą działalność trzech omawianych spółek: Lux-Medu, Medicoveru i Enel-Medu. Mowa tu głównie o ustawie z 1 października 2017 roku o sieci szpitali oraz o projekcie Ministerstwa Zdrowia na temat możliwości wprowadzenia opłat komercyjnych od pacjentów przez podmioty publiczne.

Prawdziwa burza medialna przetoczyła się w związku z przyjętą przez Parlament RP ustawą o sieci szpitali, co spotkało się z wieloma głosami krytycznymi, pełnymi obaw głównie ze strony przedstawicieli prywatnego sektora opieki zdrowotnej, w tym władz trzech analizowanych spółek. 27 czerwca 2017 roku oddziały wojewódzkie NFZ opublikowały wykazy placówek, które zakwalifikowano do tzw. sieci szpitali zgodnie z ustawą z 23 marca 2017 roku o zmianie ustawy o świadczeniach opieki zdrowotnej finansowanych ze środków publicznych, która weszła w życie 4 maja 2017 roku, a miała obowiązywać od 1 października. W ramach tej sieci znalazło się tylko 594 szpitali, w tym 78 prywatnych podmiotów. System podstawowego szpitalnego zabezpieczenia świadczeń opieki zdrowotnej (SPSZ), w ramach którego zakłady lecznicze z danego województwa zakwalifikowano do jednego z sześciu poziomów zabezpieczenia (szpitali I, II i III stopnia oraz szpitali onkologicznych lub pulmonologicznych, szpitali pediatrycznych i szpitali ogólnopolskich), określa warunki formalne kwalifikacji do każdego z tych poziomów. To właśnie kryteria formalne, związane głównie $\mathrm{z}$ wymogiem prowadzenia izby przyjęć/SOR oraz posiadaniem $w$ tym zakresie umowy z NFZ przez co najmniej dwa lata oraz kontraktu z NFZ na konkretne oddziały w tzw. trybie ostrym (nieplanowanym) również w ramach NFZ od dwóch lat, sprawiły, iż szpitalne placówki Lux-Medu, Medicovera i Enel-Medu w większości, albo wcale, nie znalazły się w sieci. W ustawie pominięto kryteria efektywnościowe placówek, dotyczące np. ich kondycji finansowej czy jakości udzielanych świadczeń (zob. Medycyna Prywatna.pl, 10 procent szpitali w sieci to placówki prywatne; MAT, PAP, Placówki odwołały się w sprawie sieci, Rzeczpospolita, lipiec 2017; Konieczny, Ustawa o sieci szpitali ogłoszona w Dzienniku Ustaw; Ministerstwo Zdrowia, Strona poświęcona sieci szpitali).

W dokumencie opublikowanym przez Ministerstwo Zdrowia na stronie poświęconej sieci szpitali w województwie mazowieckim $\mathrm{z}$ końca czerwca 2017 roku znalazły się tylko dwie placówki szpitalne Lux-Medu w Warszawie o profilu onkologicznym, działające w ramach marki Magodent przy ul. Fieldorfa i ul. Szamockiej. Trafił tam m.in. nowo otwarty szpital na Żoliborzu z 178 łóżkami oraz 38 stanowiskami do chemioterapii. Należy zatem podkreślić, że wcześniejszy zakup dwóch szpitali Magodent, który od lat posiada kon- 
trakt na leczenie onkologiczne i budowa trzeciego szpitala o tym profilu przez Lux-Med, to inwestycja trafiona w dziesiątkę i przemyślana strategia związana z zapowiadanymi już wcześniej zmianami o sieci szpitali. Na liście NFZ zabrakło jednak innych placówek Lux-Medu i nie znalazły się na niej żadne szpitale prowadzone przez Enel-Med i Medicover, w tym flagowa jednostka tej ostatniej spółki na warszawskim Wilanowie, dysponująca 180 łóżkami (Ministerstwo Zdrowia, Strona poświęcona sieci szpitali: lista szpitali zakwalifikowanych do sieci szpitali na Mazowszu; TVN Warszawa, Nowoczesny szpital onkologiczny otwarto na Żoliborzu, marzec 2017).

Sytuację tę skomentowały władze tych spółek:

[...] - Szpital Medicover w ramach kontraktu z Narodowym Funduszem Zdrowia obejmuje opieka ponad milion osób $z$ poludniowej części Warszawy $i$ województwa mazowieckiego. Świadczymy przede wszystkim wysokospecjalistyczne ustugi medyczne z zakresu kardiologii, kardiochirurgii i chirurgii naczyniowej. $W$ ramach tych specjalności świadczymy również pomoc osobom $w$ stanach naglych. Co istotne, nasze oddziaty kardiologiczne i kardiochirurgiczne reprezentuja jeden z najniższych wspótczynników śmiertelności wśród leczonych pacjentów, mimo że zajmuja się najbardziej skomplikowanymi i powiktanymi przypadkami - Marcin Łukasiewicz, dyrektor Szpitala Medicover.

[...] - Wejście w życie ustawy o sieci szpitali oznacza przede wszystkim duża niepewność. Jako szpital, który nie wszedt do sieci, nadal nie wiemy, jaka będzie przysztość ustug świadczonych $w$ ramach NFZ. Nie wiemy, czy będziemy w stanie zaoferować dalsza pomoc pacjentom, którym pomagaliśmy w problemach kardiologicznych $i$ kardiochirurgicznych, czy też od 1 października będziemy musieli wstrzymać świadczenia realizowane w ramach środków publicznych - stwierdził Marcin Łukasiewicz (Biznes newseria, Przez ustawę o sieci szpitali mieszkańcy południa Warszawy i Mazowsza mogą mieć ograniczony dostęp do specjalistycznej opieki kardiologów). Z kolei zdaniem Adama Rozwadowskiego nowa ustawa sieci szpitali powiększy jeszcze i tak długie kolejki pacjentów na zabieg.

- Pacjent, który miat np. piate miejsce w kolejce na zabieg $w$ szpitalu prywatnym, będzie teraz musiat się przepisać do szpitala sieciowego (zob. Przybylska, Onet.pl., Rozwadowski: sieć wydłuży kolejki).

Ministerstwo Zdrowia przyjęło, iż środki pochodzące z NFZ trafią w około 93\% do sieci szpitali, a pozostałe $7 \%$ będzie rozdysponowane w trakcie planowanych konkursów na świadczenia zdrowotne w ramach lecznictwa. Taka oficjalna wersja wydarzeń była aktualna tylko do lipca 2017 roku. Z uwagi na brak informacji o sposobie obliczania ryczałtu dla sieci szpitali, oddziały wojewódzkie NFZ wystąpiły - nie wiedząc, ile pieniędzy pozostanie im na kontraktowanie - do prezesa funduszu o możliwość aneksowania umów, a tylko 
w niektórych województwach ogłoszono konkursy ofert. Rozporządzenie, określające zasady obliczania ryczałtu systemu podstawowego szpitalnego zabezpieczenia świadczeń opieki zdrowotnej (PSZ), ukazało się dopiero 10 sierpnia 2017 roku. Stąd już w sierpniu NFZ podał oficjalną informację o tym, iż aneksy do umów z placówkami leczniczymi, które nie znalazły się w sieci szpitali, podpiszą oddziały funduszu z województw: mazowieckiego, podkarpackiego, śląskiego i lubuskiego. Sytuacja ta oznacza dalszą niepewność dla placówek szpitalnych trzech omawianych spółek, które nie zostały zakwalifikowane do sieci szpitali, gdyż każda z nich funkcjonuje tylko na terenie Mazowsza. Placówki szpitalne nie mogą stanąć zatem do konkursów, a liczyć teoretycznie tylko na pieniądze od publicznego płatnika przez najbliższe 6 miesięcy, ponieważ na tyle NFZ może im przedłużyć dotychczasowe kontrakty. Pozostawało poczucie niepewności, którego nie mają placówki, które znalazły się w sieci, gdyż nie muszą stawać do konkursów (choć również dodatkowo mogą ubiegać się o więcej środków tą drogą) i w ramach sieci mają zapewnione finansowanie na następne cztery lata (zob. Ministerstwo Zdrowia, Strona poświęcona sieci szpitali; Kuta, 2017; OIL Warszawa, 2017; Rynek Zdrowia, sierpień 2017.

Drugim zaskakującym rynek pomysłem Ministerstwa Zdrowia, który pojawił się z końcem czerwca 2017 roku był projekt ustawy o działalności leczniczej, wprowadzający możliwość korzystania ze świadczeń odpłatnych w publicznych szpitalach, z którego rząd wycofał się jednak bardzo szybko, w ciągu niespełna dwóch tygodni. Projekt podzielił środowisko medyczne, poza słowami aprobaty, spotkał się z krytyką, a nawet bardzo ostrym odzewem ze strony sektora prywatnego, który poczuł realne zagrożenie dla swojej dotychczasowej pozycji. Na łamach portalu Medycyny Prywatnej.pl Pracodawców Medycyny Prywatnej, Adam Rozwadowski wydał oświadczenie, w którym zaznaczył, iż nie ma możliwości realizowania odpłatnych świadczeń przez podmioty publiczne, ze względu na niezgodność tego projektu z artykułami 68 i 32 Konstytucji RP. Czy Ministerstwo Zdrowia do projektu nie powróci, na razie nie wiadomo, gdyż urzędnicy resortu zdrowia zapewnili, że projekt nie jest przekreślony i że będzie poddany ponownej analizie (zob. szerzej: Polityka Zdrowotna, czerwiec 2017; Bankier.pl, czerwiec 2017; Piekarski, RMF).

\section{Zakończenie i wnioski}

Omawiane w artykule spółki rozpoczęły swoją działalność w pierwszej połowie lat $90 . \mathrm{XX}$ wieku. Przez cały czas swojej dotychczasowej działalności z pojedynczych centrów rozwinęły się w duże sieciowe ogólnopolskie podmioty - korporacje, które obecnie nie są w stanie już tak szybko się rozwijać bez 
zewnętrznego kapitału. Każda ze spółek obrała w pewnym zakresie podobną drogę rozwoju, stawiając na opiekę medyczną dla firm i klientów indywidualnych, rozbudowując sieć przychodni w wielu miastach i stale powiększając swój potencjał. Każda z omawianych spółek, mimo iż przyjęła bardzo zbliżone modele biznesowe, oparte o dywersyfikację portfela usług medycznych, realizowała i realizuje różne podejście do rozwoju, co można zaobserwować w różnej formie organizacyjno-prawnej jako przedsiębiorstw, ich strukturze oraz znacznym zróżnicowaniu w zakresie profilu inwestowania. Różny jest również stopień zaangażowania omawianych spółek w działalność szpitalną, co w świetle planowanych zmian systemowych, związanych z tzw. sieci szpitali, czyli systemem podstawowego szpitalnego zabezpieczenia świadczeń opieki zdrowotnej (PSZ), może mieć określone konsekwencje dla dalszego rozwoju usług medycznych w ramach segmentu szpitalnego. Omawiane spółki różnicuje silnie sposób zaangażowania kapitału zewnętrznego, zakres i różnorodność usług oraz wielkość samych spółek, co determinuje perspektywy dalszego ich rozwoju. Biorąc pod uwagę dotychczasowe działania strategiczne tych spółek oraz analizując wypowiedzi ich władz należy oczekiwać, że przynajmniej Lux-Med i Medicover będą dążyły do dalszej konsolidacji rynku, ale również Enel-Med nie zrezygnuje z obranej strategii rozwoju, polegającej na powiększaniu swojego potencjału, jak i jego najefektywniejszego wykorzystania. Sieć szpitali, która zaczęła funkcjonować od października 2017 roku może co najwyżej uszczuplić w dalszej perspektywie ich przychody, ale - jak same deklarują - wysokość wszystkich kontraktów w stosunku do innych źródeł przychodów charakteryzuje się niskim procentem i nie dojdzie do załamania pozycji rynkowej tych sieci. Dużo większym, choć na razie tylko potencjalnym zagrożeniem dla tych spółek niż brak zakwalifikowania się do sieci szpitali (z uwagi na niski i tak poziom zaangażowania płatnika NFZ w strukturę przychodów każdej z trzech spółek) może być pomysł pobierania przez publiczne szpitalne placówki medyczne opłat od pacjentów, czyli de facto pomysł, który mógłby znacząco osłabić ich pozycję i postawić pod znakiem zapytania ich dalszy rozwój. Póki co, patrząc jednak na prognozy rynkowe dla prywatnych przedsiębiorców medycznych, zaprezentowane w raporcie PMR „Rynek prywatnej opieki zdrowotnej w Polsce 2017. Analiza rynku i prognozy rozwoju na lata 2017-2022" wskazują, że w najbliższych sześciu latach rynek prywatnych usług medycznych, w tym abonamentów i ubezpieczeń zdrowotnych oraz świadczeń płatnych bezpośrednio przez pacjenta, będzie rozwijał się w tempie około 6-7\% w skali roku (zob. BL, PMR, Dobre prognozy dla prywatnych przedsiębiorców medycznych, Menedżer Zdrowia). Wydaje się zatem, że obecne zmiany systemowe sygnowane przez Ministerstwo Zdrowia nie zahamują dalszej ekspansji 
trzech największych sieciowych spółek medycznych, ani ich chęci do rozwijania się. Patrząc bowiem na terminy wizyt do lekarzy specjalistów w niektórych dziedzinach, które sięgają już nie paru miesięcy, ale roku, a w przypadku zabiegów operacyjnych to nierzadko perspektywa kilkuletniej kolejki, można z dużą dozą prawdopodobieństwa powiedzieć, że właściciele i strategiczni inwestorzy tych spółek nie muszą raczej bać się o ich ekonomiczną przyszłość.

\section{Bibliografia}

Bałtowski, M., Miszewski, M. (2015). Transformacja gospodarcza w Polsce. Warszawa: Wydawnictwo Naukowe PWN S.A.

Bankier.pl (czerwiec 2017). Ministerstwo Zdrowia wycofuje się z kontrowersyjnego pomysłu: http://www.bankier.pl/wiadomosc/Ministerstwo-Zdrowia-wycofuje-sie-zkontrowersyjnego-projektu-3708319.html (dostęp: 15.06.2017).

Biznes newseria. Przez ustawę o sieci szpitali mieszkańcy południa Warszawy i Mazowsza mogą mieć ograniczony dostęp do specjalistycznej opieki kardiologów: https://biznes. newseria.pl/news/przez-ustawe-o-sieci,p852973870 (dostęp: 17.06.2017).

BL, PMR. Dobre prognozy dla prywatnych przedsiębiorców medycznych. Menedżer Zdrowia: https://www.termedia.pl/mz/Dobre-prognozy-dla-prywatnych-przedsiebiorcowmedycznych,27204.html (dostęp: 20.06.2017).

Blisko Zdrowia (listopad 2009) - Magazyn Pacjentów Centrów Medycznych Grupy Lux-Med.

Bupa, oficjalna strona Grupy Bupa: https://www.bupa.com/Corporate/about-us/our-organisation (dostęp: 22.06.2017).

Dyskusja.biz (2016). Jest przeciek. PZU będzie kontynuować przejęcia placówek medycznych, marzec 2016: http://dyskusja.biz/biznes/jest-przeciek-pzu-bedzie-kontynuowac-przejeciaplacowek-medycznych-53721 (dostęp: 02.07.2017).

Enel-Med: historia stomatologii: https://cm.enel.pl/stomatologia/o-nas/historia-stomatologii. (dostęp: 02.07.2017).

Geise, M., Oczki, J. i Piotrowski, D. (red.) (2016). Transformacja gospodarcza w Polsce. Bydgoszcz: Wydawnictwo Uczelniane Wyższej Szkoły Gospodarki.

Gilejko, L. (2009). Polska transformacja - Próba bilansu i nowa perspektywa. Res Humana (3).

GoWork.pl, Historia Medicover: http://www.gowork.pl/opinie_czytaj2,8042,0,0,historia_firmy (dostęp: 02.07.2017).

Gwozdowska, A. (wrzesień 2009). Fundusze inwestycyjne a rynek ochrony zdrowia. Puls Medycyny: http://pulsmedycyny.pl/2581201,19187,fundusze-inwestycyjne-a-rynek-ochronyzdrowia (dostęp: 05.07.2017).

Health Care Business International. Medicover ownership is now not-for-profit: https:// www.healthcarebusinessinternational.com/will-medicover-morph-into-an-east-europeanbupa (dostęp: 05.07.2017).

Informacje korporacyjne Enel-Med[a]: https://cm.enel.pl/inwestor/prezentacje/komunikaty-prasowe/debiut-enel-med-na-gieldzie-papierow-wartosciowych-w-warszawie-75qGnn (dostęp: 06.07.2017).

Informacje korporacyjne Enel-Med [b]: https://cm.enel.pl/inwestor/o-enel-med/akcjonariat (dostęp: 06.07.2017). 
Informacje korporacyjne Enel-Med [c]: https://cm.enel.pl/inwestor/prezentacje/komunikatyprasowe/enel-med-wprowadza-nowa-marke-klinike-medycyny-estetycznej-estell-y2iA6O (dostęp: 12.07.2017).

Informacje korporacyjne Enel-Med. [d]:, https://cm.enel.pl/assets/relacje_inwestorskie/prezentacje/Strategia_Centrum_Medycznego_ENEL-MED.pdf (dostęp: 12.07.2017).

Informacje korporacyjne Enel-Med. [e]: https://cm.enel.pl/inwestor/prezentacje/komunikatyprasowe/enel-med-rozwoj-nowych-marek-grupy-enel-med-oraz-wejscie-w-nowe-obszarydzialalnosci-poprzez-akwizycje-6RJGOK (dostęp: 12.07.2017).

Informacje korporacyjne Enel-Med. [f]: https://cm.enel.pl/assets/relacje_inwestorskie/raporty_okresowe/raportroczny2016/Sprawozdanie_Zarzadu_z_dzialalnosci_Spoki_2016.pdf (dostęp: 13.07.2017).

Interia Biznes (grudzień 2012). Bupa przejmie LUX MED - największą polską prywatną firmę świadczącą usługi zdrowotne: http://biznes.interia.pl/wiadomosci/news/bupaprzejmie-lux-med-najwieksza-polska-prywatna-firme,1875338,4199 (dostęp: 13.07.2017).

Interia Biznes (wrzesień 2004). Lux-Med odpiera zarzuty: http://biznes.interia.pl/news/luxmed-odpiera-zarzuty,541841 (dostęp: 21.07.2017).

Konieczny, D. Ustawa o sieci szpitali ogłoszona w Dzienniku Ustaw: https://www.zdrowie.abc.com.pl/zmiany-w-prawie/ustawa-o-sieci-szpitali-zostala-ogloszona-w-dziennikuustaw,110553.html (dostęp: 22.07.2017).

Kuta, W. (lipiec 2017). Rynek Zdrowia. Nowe konkursy czy aneksowanie - szpitale poza siecią drżą o przyszłość:http://www.rynekzdrowia.pl/Finanse-i-zarzadzanie/Nowe-konkursy-czyaneksowanie-szpitale-poza-siecia-drza-o-przyszlosc,175053,1.html (dostęp: 29.07.2017).

Leszczyński, D. (2015). Przeobrażenia gospodarcze w Polsce 1989-2016. Refleksje (12): https://pressto.amu.edu.pl/index.php/r/article/view/8145/8026 (dostęp: 29.07.2017).

Magowska, A.M. Dzieje lecznictwa Polsce. Medycyna w PRL, Medycyna Polska - branżowy portal wiedzy: http://www.medycynapolska.eu/dzieje-lecznictwa-w-polsce/medycyna-wprl-u (dostęp: 29.07.2017).

MAT, PAP (lipiec 2017). Placówki odwołały się w sprawie sieci. Rzeczpospolita: http://www. rp.pl/Zdrowie/307079897-104-placowki-odwolaly-sie-ws-sieci-szpitali.html\#ap-1 (dostęp: 29.07.2017).

MB (2007). Enel-Med szuka wyjść awaryjnych. Puls Biznesu 2007: https://www.pb.pl/enelmed-szuka-wyjsc-awaryjnych-401351 (dostęp: 29.07.2017).

Medicover.com. Oficjalna strona Grupy Medicover: https://ww.medicover.com/about-us/ourhistory (dostęp: 29.08.2017).

Medicover.com. Oficjalna strona Grupy Medicover: https://www.medicover.com/files/public/ uploads/Medicover_engV2.pdf (dostęp: 29.09.2017).

Medycyna Prywatna.pl. 10 procent szpitali w sieci to placówki prywatne: http://medycynaprywatna.pl/59-prywatnych-placowek-w-sieci-szpitali (dostęp: 02.08.2017).

Ministerstwo Zdrowia (a). Strona poświęcona sieci szpitali: http://siecszpitali.mz.gov.pl (dostęp: 02.08.2017).

Ministerstwo Zdrowia (b). Strona poświęcona sieci szpitali: lista szpitali zakwalifikowanych do sieci szpitali na Mazowszu: http://siecszpitali.mz.gov.pl/nfz/Mazowiecki_OW.pdf (dostęp: 02.08.2017).

Ministerstwo Zdrowia (c). Strona poświęcona sieci szpitali:http://siecszpitali.mz.gov.pl: (dostęp: 02.08.2017).

MM (2011). Medicover przejmuje Dantex. Puls Medycyny, wrzesień 2011: http://pulsmedycyny.pl/3319024,86767,medicover-przejmuje-dantex-med (dostęp: 03.08.2017). 
OIL Warszawa (sierpień 2017). W części województw NFZ aneksuje umowy ze szpitalami poza siecią: http://izba-lekarska.pl/monitor-lekarski/w-czesci-wojewodztw-nfz-aneksujeumowy-ze-szpitalami-poza-siecia: (dostęp: 19.08.2017).

PAP (2016). Enel-Med rezygnuje z wejścia na GPW w 2006 roku. Puls Biznesu 2006: https://www.pb.pl/enel-med-rezygnuje-z-wejscia-na-gpw-w-2006-roku-308204 (dostęp: 19.08.2017).

Parkiet. Kolejne przejęcie Lux Medu: http://www.parkiet.com/artykul/1350723.html (dostęp: brak).

Piekarski, M. Resort nie rezygnuje z pomysłu opłat za leczenie w szpitalach. RMF: http://www. rmf24.pl/fakty/polska/news-resort-zdrowia-nie-rezygnuje-z-pomyslu-oplat-za-leczenie-ws,nId,2408303 (dostęp: 19.08.2017).

Polityka Zdrowotna (czerwiec 2017). Współpłacenie - pomysł dobry, ale niedoskonały?: http://www.politykazdrowotna.com/20135,wspolplacenie-pomysl-dobry-ale-niedoskonaly (dostęp: 20.08.2017).

Portal Grupy Lux-Med. (grudzień 2013): http://www.luxmed.pl/grupa-lux-med/biuro-prasowe/ informacje-prasowe.html (dostęp: 20.08.2017).

Portal Magodent: http://www.magodent.pl/aktualnosci/magodent-w-grupie-lux-med (dostęp: 20.08.2017).

Portal Zdrowie ABC (2015). Medicover kupił spółkę Allenort, luty 2015: https://www.zdrowie.abc.com.pl/artykuly/medicover-kupil-spolke-allenort-kardiologia,3976.html (dostęp: 26.08.2017).

Portal Zdrowie.abc (kwiecień 2015). Grupa Lux-Med: przejęcie sieci medycznej Medicor z Rzeszowa: https://www.zdrowie.abc.com.pl/artykuly/grupa-lux-med-przejecie-siecimedycznej-medicor-z-rzeszowa,7522.html (dostęp: 26.08.2017).

Portal Zdrowie.abc (październik 2015). 23 akwizycje w 8 lat. Lux-Med przejmuje EuroClinic: https://www.zdrowie.abc.com.pl/artykuly/23-akwizycje-w-8-lat-lux-med-przejmujeeuro-clinic,19875.html (dostęp: 26.08.2017).

Prezentacja dla inwestorów: Enel-Med idzie na giełdę. Perspektywy rozwoju i strategia: https://cm.enel.pl/assets/relacje_inwestorskie/prezentacje/Prezentacja_na_IPO_Day_ luty_2011.pdf (dostęp: 26.08.2017).

Prospekt emisyjny Enel-Med: https://cm.enel.pl/assets/relacje_inwestorskie/prospekt/Prospekt_emisyjny_ENEL-MED.pdf (dostęp: 26.08.2017).

Przybylska, N. Onet.pl. Rozwadowski: sieć wydłuży kolejki: http://biznes.onet.pl/wiadomosci/ kraj/siec-szpitali-komentarz-prezesa-enel-med/v321dv (dostęp: 26.08.2017).

Ragus, A. (2014). Wilanów: Szpital Medicover do rozbudowy. Nasze miasto.pl Warszawa, październik 2014: http://warszawa.naszemiasto.pl/artykul/wilanow-szpital-medicover-dorozbudowy,2465275,art,t,id,tm.html (dostęp: 28.08.2017).

Raport z działalności Fundacji Medicover 2015: http://raportyspoleczne.pl/wp-content/uploads/raports/776959352005a817aad8c5aa2747befd.pdf (dostęp: 28.08.2017).

Rulkiewicz, A. Lider w warunkach radykalnej zmiany. Harvard Business Review: https:// www.hbrp.pl/b/lider-w-warunkach-radykalnej-zmiany/1EOH4w5U5 (dostęp: 29.08.2017).

Rynek Zdrowia (sierpień 2017). Ruszyły niektóre konkursy na świadczenia poza siecią szpitali: http://www.rynekzdrowia.pl/Finanse-i-zarzadzanie/Swiadczenia-poza-siecia-szpitaliruszyly-niektore-konkursy,175473,1.html (dostęp: 30.08.2017).

Scandinavian-Polish Chamber of Commerce, Medicover Poland: Debiut Medicover AB na Giełdzie w Sztokholmie: https://www.spcc.pl/news/members/details/20015 (dostęp: 30.08.2017). 
Stowarzyszenie Inwestorów Indywidualnych: czat inwestorski: http://www.sii.org.pl/9756/ aktualnosci/czat-inwestorski/czat-inwestorski-omowienie-zrealizowanych-inwestycjii-najblizszych-planow-inwestycyjnych-centrum-medycznego-enelmed.html (dostęp: 01.09.2017).

TVN (marzec 2017). Warszawa. Nowoczesny szpital onkologiczny otwarto na Żoliborzu: http://tvnwarszawa.tvn24.pl/informacje,news,nowoczesny-szpital-onkologiczny-otwarto-nazoliborzu,228083.html (dostęp: 02.09.2017).

Twoje Zdrowie (zima 2003) - kwartalnik Lux-Medu: http://www.luxmed.pl/_files/ f6b651501e53b277bfd208ae6a8a17e6.pdf (dostęp: 02.09.2017).

Urbanity.pl, Szpital Medicover: http://www.urbanity.pl/mazowieckie/warszawa/szpitalmedicover,b3941 (dostęp: 02.09.2017).

Wierzchowska, M. (2017). Medicover bogatszy o 1 miliard. Puls Biznesu, maj 2017 r.: https:// www.pb.pl/medicover-bogatszy-o-1-mld-zl-862631 (dostęp: 02.09.2017). 


\title{
Karolina Hawryluk ${ }^{1}$ \\ Tomasz Hermanowski ${ }^{2}$
}

\section{Koszty reklamy leków OTC i suplementów diety w Polsce}

\begin{abstract}
Streszczenie
Artykuł dotyczy kosztów reklamy leków bez recepty (OTC) oraz suplementów diety w Polsce. Polska należy do czołówki krajów Unii Europejskiej, w których spożywa się najwięcej leków OTC oraz suplementów diety. Wiedza Polaków na temat suplementów diety oraz świadomość istotnych różnic między lekami bez recepty (OTC) a suplementami diety jest na niskim poziomie. Jednocześnie od lat obserwuje się sezonowość w emisji reklam produktów zdrowotnych i leczniczych w czasie antenowym przeznaczonym na reklamy telewizyjne. Leki i suplementy diety reklamowane są głównie w okresie jesienno-zimowym oraz wiosennym z uwagi na nasilone występowanie przeziębień i grypy. Wydatki na marketing firm farmaceutycznych reklamujących leki bez recepty i suplementy diety w przeciągu 10 lat wzrosły czterokrotnie, oba rynki warte są miliardy złotych. W 2015 roku firmy z sektora farmaceutycznego przeznaczyły na reklamę leków OTC 4,3 mld zł z podziałem na następujące kanały przekazu: w telewizji 2,82 mld zł, a w stacjach radiowych 1,12 mld zł.

Niestety, nakłady finansowe na prace badawczo-rozwojowe nie rosną w takim samym tempie, jak wydatki na reklamę. Firmy farmaceutyczne często nie prowadzą badań nad lekami na choroby rzadkie ze względów ekonomicznych oraz brak opłacalności. Opodatkowanie reklamy leków OTZ i suplementów diety, wzorem podatku Garattiniego, który funkcjonuje we Włoszech od 2005 roku, umożliwiłoby przeznaczenie zgromadzonych środków na niezależne badania kliniczne nad lekami sierocymi, szerokie informowanie społeczeństwa o zasadach stosowania leków OTC oraz
\end{abstract}

1 Karolina Hawryluk - mgr, absolwentka Warszawskiego Uniwersytetu Medycznego, były członek Studenckiego Koła Naukowego Farmakoekonomiki, e-mail: Karolina.hawryluk@o2.pl.

2 Tomasz Hermanowski - prof. dr hab. n. o zdrowiu, Zakład Prawa Farmaceutycznego i Farmakoekonomiki Warszawskiego Uniwersytetu Medycznego, Prezes Zarządu Polskiego Towarzystwa Ekonomiki Zdrowia, Kierownik Projektu DUO OTM, 02-576 Warszawa, ul. Litewska 14/16, e-mail: tomasz.hermanowski@biznes.edu.pl; ORCID: 0000-0002-1659-8719. 
suplementów diety, zwłaszcza przyjmowanych w połączeniu z lekami na receptę czy refundację nowych leków sierocych i innych ratujących życie.

Słowa kluczowe: koszty reklamy leków, koszty suplementów.

\title{
Advertising Costs of OTC Drugs and Food Supplements in Poland
}

\begin{abstract}
The article concerns the advertising costs of non-prescription (OTC) drugs and food supplements in Poland. Poland is one of the leading European Union countries in which the most OTC drugs and food supplements are consumed. Poles' knowledge about food supplements and awareness of significant differences between OTC drugs and food supplements is at a low level. At the same time, it has been observed for years that advertisements of health and medicinal products are broadcast in the air time intended for TV commercials in certain seasons. Drugs and food supplements are advertised mainly in autumn, winter and spring due to the increased prevalence of colds and flu. Marketing expenses of pharmaceutical companies advertising OTC drugs and food supplements have increased fourfold within 10 years, and both markets are worth billions of zlotys. In 2015, pharmaceutical companies spent 4.3 billion zlotys on advertisements of OTC drugs, divided into the following media: television - 2.82 billion zlotys and radio stations - 1.12 billion zlotys.

Unfortunately, financial outlays for research and development are not growing at the same pace as advertising spending. Pharmaceutical companies often do not do any research on drugs for rare diseases because of economic reasons and a lack of profitability. Taxation of advertisements of OTC drugs and food supplements, similar to Garattini's tax, which has been imposed in Italy since 2005, would allow the allocation of accumulated resources to independent clinical trials on orphan drugs, provision of the public with broad information on the principles of use of OTC drugs and food supplements, especially those taken in combination with prescription drugs, or reimbursement of costs of new orphan and other life-saving drugs.
\end{abstract}

Keywords: Advertising Costs of OTC Drugs, advertising Costs Food Supplements.

\section{Wstęp}

Promocja i sprzedaż to podstawy złożonej definicji marketingu. Według Philipa Kotlera, marketing to proces społeczny i zarządczy, dzięki któremu jednostki i grupy uzyskują to, czego potrzebują lub pragną przez tworzenie oraz wzajemną wymianę produktów i wartości, kreując popyt i podaż (Kotler, Armstrong, Saunders i Wong, 2002, s. 11, 12). Termin reklama pochodzi od terminów łacińskich reclamo, reclamare, reclamavi, reclamatum, oznaczających „głośne nawoływanie”, „przywoływanie lub wzywanie”. Pojęcia te wywodzą 
się ze średniowiecza, wówczas kupcy nawoływali przechodniów do kupna produktów na jarmarkach, targowiskach czy ulicach. W ten sposób sprzedający przedstawiali swoją ofertę, połączoną z komunikatem perswazyjnym, mającym na celu zwrócenie uwagi ludzi i skłonienie ich do nabycia lub skorzystania z określonych towarów lub usług (Starzyńska, 2015, s. 276).

Ludzie przejawiają wiele potrzeb, co doskonale opisuje piramida potrzeb Abrahama Maslowa. U jej podstaw leżą potrzeby fizjologiczne, do których zaliczamy m.in. zdrowie. Zdrowie jest ważne dla każdego człowieka, szczególne znaczenie nabiera we współczesnym świecie, w którym mamy starzejące się społeczeństwo. W Polsce przeciętna długość życia wynosi wśród mężczyzn 74 lata, a wśród kobiet 81,8 lata (GUS, 2018, s. 15). Wzrost długości życia to większe zapotrzebowanie na usługi i procedury medyczne, opiekę ambulatoryjną i szpitalną oraz leki. Gospodarstwa domowe w 2013 roku średnio miesięcznie wydały na leki i artykuły medyczne 37 zł na osobę, co stanowiło 66,7\% średnich medycznych wydatków na ochronę zdrowia w Polsce. W 2016 roku przeciętne miesięczne wydatki na leki i inne artykuły medyczne w całej populacji ludności gospodarstw domowych w Polsce wzrosły w stosunku do 2013 roku i wyniosły 38,09 zł na osobę.

Wydatki stanowiły (łącznie $\mathrm{z}$ wydatkami na medyczne dobra trwałego użytku) 69,2\% średnich miesięcznych bezpośrednich wydatków gospodarstw domowych na ochronę zdrowia ogółem w Polsce (GUS 2017, s. 74). Warto podkreślić że, wydatki te stale rosną w porównaniu do 2014 roku (GUS 2014, s. 57). Jest to ważna wiadomość dla polskiego rynku farmaceutycznego, który przoduje w krajach Europy pod względem sprzedaży leków OTC (ang. overthe-counter drug) oraz suplementów diety. Artykuł 2 ustawy z dnia 6 września 2001 roku o prawie farmaceutycznym (DzU z 2001 r., nr 126, poz. 1381 ze zm.) definiuje produkt leczniczy jako substancję lub mieszaninę substancji, przeznaczoną do zapobiegania lub leczenia chorób występujących u ludzi, podawaną człowiekowi w celu postawienia diagnozy lub przywrócenia, poprawienia czy modyfikacji fizjologicznych funkcji organizmu ludzkiego. OTC, należą do produktów leczniczych wydawanych bez recepty. Suplement diety według definicji Ustawy z dnia 25 sierpnia 2006 roku o bezpieczeństwie żywności i żywienia (art. 3, ust. 3. DzU 2006, nr 171 poz. 1225 ze zm.), to środek spożywczy, którego celem jest uzupełnienie normalnej diety, będący skoncentrowanym źródłem witamin lub składników mineralnych, lub innych substancji wykazujących efekt odżywczy, wprowadzany do obrotu w formie umożliwiającej dawkowanie, w postaci: kapsułek, tabletek, drażetek oraz w innych podobnych postaciach. 


\section{Wydatki na reklamę}

W Polsce prawo farmaceutyczne dopuszcza reklamę w środkach masowego przekazu (tj. w: telewizji, stacjach radiowych, gazetach i magazynach) produktów leczniczych, do których należą leki bez recepty (OTC), suplementy diety oraz wyroby medyczne (Rozporządzenie Ministra Zdrowia z dnia 21 listopada 2008 roku w sprawie reklamy produktów leczniczych. DzU z 2008 r., nr 210 poz. 1327). Ustawa o prawie farmaceutycznym za reklamę produktu leczniczego uważa działalność, polegającą na informowaniu lub zachęcaniu do stosowania produktu leczniczego, mającą na celu zwiększenie: liczby przepisywanych recept, dostarczania, sprzedaży lub konsumpcji produktów leczniczych. Wprowadzono następujące ograniczenia odnoszące się do reklamy produktu leczniczego, definiujące, że reklama nie może:

- wprowadzać w błąd, powinna prezentować produkt leczniczy obiektywnie oraz informować o jego racjonalnym stosowaniu;

- polegać na oferowaniu lub obiecywaniu jakichkolwiek korzyści w sposób pośredni lub bezpośredni w zamian za nabycie produktu leczniczego lub dostarczanie dowodów, że doszło do jego nabycia;

- być kierowana do dzieci, ani zawierać żadnego elementu, który jest do nich kierowany.

Ponadto, reklama produktu leczniczego, będąca przypomnieniem pełnej reklamy, poza jego nazwą własną i nazwą powszechnie stosowaną, może zawierać tylko znak towarowy niezawierający odniesień do wskazań leczniczych, postaci farmaceutycznej, dawki, haseł reklamowych lub innych treści reklamowych.

Reklama produktu leczniczego kierowana do publicznej wiadomości porusza aspekt podmiotowości określający, że reklama nie może polegać na odwoływaniu się do zaleceń lub prezentowaniu produktu leczniczego przez osoby znane publicznie, naukowców, osoby posiadające wykształcenie medyczne lub farmaceutyczne lub sugerujące posiadanie takiego wykształcenia.

W ustawie została określona też podmiotowość poprzez zabranianie kierowania do publicznej wiadomości reklamy dotyczącej produktów leczniczych:

- wydawanych wyłącznie na podstawie recepty;

- zawierających środki odurzające i substancje psychotropowe;

- umieszczonych na wykazach leków refundowanych, zgodnie z odrębnymi przepisami, oraz dopuszczonych do wydawania ich bez recept o nazwie identycznej z umieszczonymi na tych wykazach (Ustawa z dnia 6 września 2001 roku o prawie farmaceutycznym, rozdział 4 reklama produktów leczniczych, art. 52, 53, 57. DzU z 2001 r., nr 126 poz. 1381 ze zm.). 
Regulacje prawne odnoszące się do reklamy suplementów diety nie są tak szczegółowe. Dokładne wymogi są określone w art. 27 ust. 5 ustawy o bezpieczeństwie żywności i żywienia. Przepis stanowi, że oznakowanie, prezentacja i reklama suplementów diety nie mogą zawierać informacji stwierdzających lub sugerujących, że zbilansowana i zróżnicowana dieta nie może dostarczyć wystarczających dla organizmu ilości składników odżywczych. Jednak ustawa nie definiuje pojęcia reklamy. $Z$ uwagi na brak szczegółowych przepisów odnoszących się do reklamy suplementów diety, pomocniczo stosuje się przepisy innych ustaw (Ustawy z dnia 16 kwietnia 1993 roku o zwalczaniu nieuczciwej konkurencji oraz Ustawy z dnia 16 lutego 2007 roku o ochronie konkurencji i konsumentów), odnoszących się do obszaru ochrony konkurencji i konsumentów. Sam proces wprowadzenia nowego suplementu na rynek nie wymaga przeprowadzenia wcześniejszych badań klinicznych. Wystarczy tylko zgłosić do Głównego Inspektora Sanitarnego (GIS) wprowadzenie suplementu do obrotu podając, jakie składniki w nim występują oraz w jakiej formie i ilości. Taki system notyfikacji pozwala na wprowadzenie do obrotu suplementu diety bez wcześniejszego zbadania i zweryfikowania składu produktu, nie wstrzymując przy tym jego dystrybucji. W momencie wykrycia w produkcie szkodliwych substancji, produkt może cały czas znajdować się na rynku w sprzedaży. Sam proces rozpatrywania powiadomień od momentu przekazania ich do GIS przez firmę wprowadzającą produkt na rynek do rozpoczęcia procedury weryfikacji trwa około 8 miesięcy. Warto zaznaczyć, że wobec około 6 tysięcy powiadomień z lat 2014-2016 nie podjęto procesu weryfikacji. Wprowadzając tym samym produkt bez gwarancji bezpieczeństwa dla konsumenta (https://www.nik.gov. $\mathrm{pl} /$ aktualnosci/nik-o-dopuszczaniu-do-obrotu-suplementow-diety.html; dostęp: 13.04.2017).

Leki bez recepty (OTC) oraz suplementy diety są bardzo często reklamowane w telewizji i innych środkach przekazu medialnego. W 2013 roku przeprowadzono wśród 510 konsumentów powyżej 18 roku życia badanie ankietowe. Respondenci mieli wskazać formy reklam stosowanych na polskim rynku farmaceutycznym. Uczestnicy badania najczęściej wskazywali na formę reklamy w postaci:

- spotów telewizyjnych (85,7\%, 437 osób),

- reklamy w aptekach i punktach sprzedaży - typu standy i ulotki $(64,7 \%$, 330 osób),

- plakatów w aptekach i przychodniach (63,3\%, 323 osoby),

- gazetek aptecznych (61,4\%,313 osób),

- spotów radiowych $(60,8 \%, 310$ osób),

- reklam internetowych (57,8\%, 295 osób), 
- ulotek informacyjnych (51,4\%, 262 osoby),

- rekomendacji lekarzy lub farmaceutów (45,3\%, 231 osób),

- rekomendacji znajomych $(41,2 \%, 210$ osób),

- reklamy prasowej (41\%, 209 osób),

- bilbordów na ulicach (38,2\%, 195 osób),

- gadżetów reklamowych (24,3\%, 124 osoby),

- reklamy za pośrednictwem poczty $(9,4 \%, 48$ osób),

- reklamy kinowej (8,6\%, 44 osoby) (Syrkiewicz-Świtała, Holecki i Mazur, 2015, s. 285-294).

Warto podkreślić, że wiedza Polaków na temat suplementów diety, a także świadomość istotnych różnic między lekami bez recepty (OTC) a suplementami diety, jest na niskim poziomie. Jak wynika z przeprowadzonego w 2014 roku badania przez TNS Polska, co czwarty Polak ma problem z zdefiniowaniem pojęcia „suplement diety”, a tylko $27 \%$ pytanych ankietowanych trafnie określiło suplementy diety jako dodatek lub uzupełnienie do diety. Część ankietowanych mylnie uznała suplementy diety za „witaminy” (31\%), czy „minerały” (8\%), natomiast aż $41 \%$ badanych przypisało suplementom diety właściwości lecznicze, których produkty te nie mają (Informacja o wynikach kontroli. Dopuszczenie do obrotu suplementów diety, 2017). Zaobserwowano też niską świadomość społeczną odnoszącą się do kontroli bezpieczeństwa suplementów diety $-37 \%$ ankietowanych twierdziło, że suplementy diety są poddawane kontroli skuteczności ich działania, a 50\% uważało, że suplementy diety podlegają takiej samej kontroli, jak leki (zob. Raport „Świadome samoleczenie w Polsce" - http://www.lekiczysuplementy.pl 2014).

Jak wskazuje przeprowadzone badanie, najczęstszym i o najszerszym zasięgu środkiem przekazu informacji o lekach OTC oraz suplementach diety, docierającym do konsumenta jest reklama telewizyjna. Należy zaznaczyć, że czas antenowy w telewizji dostępny dla reklamodawców znacząco wzrósł. W 1956 roku w początkowym okresie rozwoju reklamy w Polsce wynosił on 15 minut w tygodniu. Od 10 marca 2010 roku do 13 listopada 2018 roku czas nadawania telewizyjnych spotów reklamowych i spotów telesprzedażowych nie mógł w danej godzinie zegarowej przekraczać 20\%, czyli 12 minut w godzinie zegarowej (zob. Dyrektywa Parlamentu Europejskiego i Rady 2010/13/UE z dnia 10 marca 2010 roku). W przeliczeniu na częstotliwość tygodniową, dawało to 2016 minut w tygodniu.

Od 14 listopada 2018 roku wprowadzono nowe wytyczne audiowizualnych usług medialnych. Dzielące dobę na przedziały czasowe i określające czas nadawania telewizyjnych spotów reklamowych i telesprzedażowych 
w godzinach $06.00-18.00$ nie przekraczający $20 \%$ tego przedziału czasowego oraz czas nadawania telewizyjnych spotów reklamowych i telesprzedażowych w godzinach $18.00-24.00$ nie przekraczający $20 \%$ tego przedziału czasowego. W pozostałym przedziale czasowym reklamy mogą być emitowane bez ograniczeń (zob. Dyrektywa Parlamentu Europejskiego i Rady (UE) 2018/1808 z dnia 14 listopada 2018 roku).

Jednocześnie od wielu lat obserwuje się sezonowość w emisji reklam produktów zdrowotnych i leczniczych w czasie antenowym przeznaczonym na reklamy telewizyjne. Leki i suplementy diety są reklamowane głównie w okresie jesienno-zimowym oraz wiosennym $\mathrm{z}$ uwagi na nasilone występowanie przeziębień i grypy (Cianciara, Piotrowicz i Żochowski, 2013, s. 226-233). Raport Krajowej Rady Radiofonii i Telewizji pokazuje że od 1997 roku do 2015 roku liczba reklam z sektora Produkty zdrowotne i leki w programach telewizyjnych wzrosła blisko 20 razy w stosunku do ogólnego trzykrotnego wzrostu liczby reklam. W 2015 roku blisko co czwarta reklama (24,7\% wszystkich reklam telewizyjnych) wyemitowana w spotach telewizyjnych poruszała tematykę produktów zdrowotnych i leków.

Producenci i dystrybutorzy leków bez recepty, parafarmaceutyków i suplementów diety wydali w 2005 roku ponad pół miliarda złotych na reklamę telewizją, a całkowite wydatki wyniosły prawie miliard złotych (Hermanowski, Drozdowska, 2012, s. 526-530). Według danych firmy Expert Monitor, w 2007 roku producenci leków OTC, parafarmaceutyków oraz suplementów diety przeznaczyli na reklamowanie swoich produktów około 1,26 mld zł (Ulatowska-Szostak, 2008, s. 441-444). Nakłady na reklamę produktów emitowanych w telewizji i prasie stale rosną. W 2015 roku firmy z sektora farmaceutycznego przeznaczyły na reklamę leków OTC 4,3 mld zł z podziałem na źródła przekazu: w telewizji - 2,82 mld zł, w stacjach radiowych - 1,12 miliarda złotych, w gazetach i magazynach - 0,36 mld zł. W 2015 roku rynek leków bez recepty był wart 9,89 mld zł (zob. Zajdel). Producenci suplementów diety w 2015 roku na promocję swoich produktów wydali $871 \mathrm{mln}$ zł.

Oddziaływanie reklamy na konsumentów potwierdza stale rosnąca sprzedaż. W ostatnich pięciu latach wartość sprzedaży na polskim rynku leków sprzedawanych bez recepty oraz suplementów diety wzrosła o blisko $40 \%$ (średnioroczne tempo wzrostu 8\%) i w 2015 roku wyniosła ponad 13,5 mld zł. Biorąc pod uwagę tylko suplementy diety w 2015 roku Polacy wydali na nie ponad 3 mld zł (Mokrysz-Olszyńska, 2016, s. 233-250). Według danych Nielsen Audience Measurement w 2010 roku w Polsce wyemitowano ponad 1,4 milionów reklam telewizyjnych dotyczących produktów farmaceutycznych, w 2015 roku liczba ta wzrosła do ponad 4,3 mln zł (zob. Gospodarcze skutki 
wprowadzenia zakazu reklamy leków OTC i suplementów diety, grudzień 2016). W dziesięciu latach budżet przeznaczany przez firmy farmaceutyczne na reklamę wzrósł czterokrotnie, świadczy to o dynamice prężnie rozwijającego się rynku, mimo kryzysu zarówno gospodarczego, jak i światowego z 2008 roku. W pierwszych trzech kwartałach 2016 roku, wydatki reklamowe niektórych firm wyniosły ponad $207 \mathrm{mln}$ zł (zob. Sektor Farmaceutyczny stawia na rekla$m e ̨)$. Warto zaznaczyć, że koszty marketingu i reklamy są wliczone w cenę leku OTC lub suplementu diety, za które płaci konsument. W rzeczywistości nakłady przeznaczane na reklamę mogą być o wiele większe, gdy uwzględnimy przedstawicieli medycznych, próbki produktów i mecenat. Na rynku występują firmy, które utrzymują się tylko z kampanii reklamowych i nie inwestują ani $\mathrm{w}$ przedstawicieli medycznych, ani w mecenat.

\section{Sprzedaż leków OTC i suplementów diety}

Firmy farmaceutyczne wśród leków OTC sprzedają najczęściej środki przeciw przeziębieniu i przeciwbólowe, pobudzające i odpornościowe oraz witaminy (Bieńko, 2014). Wśród suplementów diety największy potencjał rozwoju mają suplementy diety dla sportowców i odchudzające, preparaty na libido oraz witaminy i minerały, będące suplementami diety.

W 2005 roku wartość rynku suplementów diety w Polsce wynosiła $782 \mathrm{mln}$ zł (zob. PMR. Rynek suplementów diety w Polsce). Według szacunków firmy PMR, specjalizującej się w consultingu i badaniu rynku, w 2011 roku wartość całego rynku farmaceutycznego w Polsce wynosiła $31,7 \mathrm{mld}$ zł, z czego 7,9 mld zł to wartość rynku leków OTC i suplementów diety. Zatem, sprzedaż leków OTC i suplementów diety stanowiła jedną czwartą całego rynku farmaceutycznego w Polsce.

W 2011 roku Association of the European Self-Medication Industry (AESGP) - reprezentacja europejskich producentów leków OTC, suplementów diety i wyrobów medycznych podała, że udział na polskim rynku leków zakupionych na zlecenie lekarza lub samodzielnie (tzw. OTC, wyrobów medycznych, suplementów diety itp.), stanowiących $32 \%$ całego rynku farmaceutycznego, był najwyższy w całej Europie. W tym samym czasie również Polski Związek Producentów Leków Bez Recepty (PASMI) podał zbliżone dane. W 2011 roku rynek leków OTC, w tym suplementów diety miał około 35\% udziału w rynku farmaceutycznym w Polsce, gdzie leki OTC stanowiły 19,1\% rynku, liczonego według cen producenta. Jedną z przyczyn takiego udziału w rynku farmaceutycznym leków OTC i suplementów diety jest stale wzrastająca liczba zgłaszanych nowych produktów OTC do obrotu w Urzędzie Rejestra- 
cji Produktów Leczniczych, Wyrobów Medycznych i Produktów Biobójczych (Cianciara, Piotrowicz i Żochowski, 2013, s. 226-233).

W 2015 roku wartość rynku suplementów diety wyceniona została na 3,55 mld zł. Przez pojęcie wartość suplementów diety, należy rozumieć sprzedaż: detaliczną apteczną, poza apteczną oraz przez Internet. Z zaobserwowanej dynamiki wynika, że sprzedaż poza apteczna rośnie szybciej niż sprzedaż apteczna (zob. Sektor Farmaceutyczny stawia na reklame). Na trzykrotny wzrost wartości rynku mają wpływ czynniki makroekonomiczne, m.in. konsumpcja prywatna, zachowania konsumenckie oraz dochód rozporządzalny (zob. Sfera Biznesu Polska. Raport PMR: Polacy uwielbiaja suplementy diety). W obszarze zjawisk społecznych na rozwój branży mają wpływ: moda na zdrowy styl życia, wzrost świadomości zdrowotnej, zamożność społeczeństwa, poszerzenie koszyka dóbr konsumenckich oraz ostatnio zaobserwowane zjawisko samoleczenia (zob. Master Pharm. Opis branży suplementów diety). W 2015 roku wartość sprzedaży aptecznej leków OTC wyniosła 6 mld zł, a suplementów diety około 2,8 mld zł. Całkowita wartość rynku została oszacowana na 10,4 miliarda złotych w cenach detalicznych (zob. Ustawa $z$ dnia 6 września 2001 roku o prawie farmaceutycznym, rozdział 4 reklama produktów leczniczych, art. 52, 53, 57).

\section{Wydatki na prace badawczo-rozwojowe nad lekami w Polsce i opodatkowanie reklam leków}

Szacuje się, że w latach 2007-2009 wydatki na badania i rozwój głównych krajowych producentów leków wyniosły $558 \mathrm{mln}$ zł (zob. Firma CASE Doradcy, Farmacja nie oszczędza na wydatkach na badania). Rynek badań klinicznych w 2010 roku w Polsce był wart 900 mln zł i wtedy też był jednym z największych w Europie Środkowo-Wschodniej (zob. Sektor farmaceutyczny $i$ biotechnologiczny w Polsce, s. 1-8). W 2014 roku wartość rynkowa badań klinicznych w Polsce wyniosła 950 mln złotych (Raport PWC, luty 2016). Zgodnie z założeniami ekonomii, przedsiębiorstwa farmaceutyczne dążą do maksymalizacji zysku. Ryzykowne lub drogie i nieekonomiczne prace badawczo-rozwojowe nie są finansowane przez branżę farmaceutyczną. Jest to jedną z głównych przyczyn nieprowadzenia badań nad lekami na choroby rzadkie lub nad lekiem sierocym. W ostatnich latach pogorszyła się znacząco jakość i efektywność prac naukowo-badawczych. Rejestruje się coraz mniej nowych leków (Booth, Zemmel, 2004, s. 451-456). W Polsce w 2009 roku zarejestrowanych było 469 badań klinicznych, a w 2014 roku liczba ta wyniosła 396 (PWC, grudzień 2015, s. 1-12).

Na przestrzeni ostatnich 10 lat w Polsce nie odnotowano znacznego wzrostu nowo zarejestrowanych badań klinicznych. Z raportu firmy PWC na temat 
badań klinicznych przeprowadzonych w Polsce wynika, że rocznie rejestruje się około 10,4 nowych badań na 1 milion osób w populacji (zob. Przyszłość Farmaceuty - Badania kliniczne pod lupa). Dla porównania, liczba prowadzonych badań klinicznych w przeliczeniu na mieszkańca w krajach Europy Środkowo-Wschodniej, tj. w Czechach czy na Węgrzech, jest prawie dwukrotnie wyższa. Obecnie badania kliniczne w znaczącym stopniu są finansowane przez komercyjne firmy farmaceutyczne, które nie są zainteresowane finansowaniem badań nad lekiem sierocym. W celu poprawy opieki zdrowotnej rządy powinny stworzyć model finansowania niezależnych badań klinicznych, opartych na faktach naukowych (ang. Evidence Based Medicine) i opiniach wydawanych przez Agencję Oceny Technologii Medycznych i Taryfikacji (AOTMiT).

Na ogromną sumę pieniędzy wydawaną przez Polaków na suplementy diety oraz na potrzebę zmian zwraca uwagę Prezes Polskiej Federacji Szpitali. Jarosław Fedorowski w wywiadzie dla gazety Menedżer Zdrowia, powiedział, że: „Polska Federacja Szpitali apeluje do uczestników systemu o podjęcie wspólnych działań, by środki te wykorzystać na poprawę finansowania polskich szpitali, borykających się z rosnącymi problemami finansowymi" (Menedżer Zdrowia, 2017(1), s. 6). Rozwiązaniem obecnej sytuacji w branży farmaceutycznej, gdzie większe nakłady są ponoszone na reklamę niż na badania naukowe nad nowymi lekami, może być wprowadzenie podatku od reklamy leków, tzw. podatek Garattiniego. Po raz pierwszy został on wprowadzony we Włoszech w 2005 roku przez Dział Badań i Rozwoju Włoskiej Agencji ds. Leków (AIFA). Firmy farmaceutyczne odprowadzają podatek w wysokości 5\% nakładów ponoszonych na reklamę i marketing, z którego są przeprowadzane niezależne badania kliniczne, szczególnie wspierające badania nad rzadkimi chorobami.

Po trzech latach działalności programu udało się osiągnąć przychód podatkowy w wysokości $45 \mathrm{mln}$ euro rocznie. Uzyskane środki podzielono po połowie: na niezależne badania i informacje o lekach dostępne dla obywateli oraz refundację nowych leków sierocych i ratujących życie (Liberati, 2010, s. 69-86).

W Polsce w 2011 roku powstał projekt ustawy refundacyjnej, który proponował przekazywanie równowartości 3\% przychodu firmy farmaceutycznej z tytułu objęcia leków refundacją, na rzecz Agencji Oceny Technologii Medycznych (AOTM). Projekt ustawy został odrzucony w wyniku prowadzonych rozmów z przedstawicielami firm farmaceutycznych, ekspertów i innych interesariuszy. Ostatecznie przytoczonym argumentem przeciwko zmianom było zwrócenie uwagi na próbę opodatkowania dochodów firm farmaceutycznych ze sprzedaży leków refundowanych. 
W czerwcu 2016 roku Minister Zdrowia powołał zespół ds. uregulowania reklamy leków, suplementów diety i innych środków spożywczych oraz wyrobów medycznych. W skład zespołu wchodzili przedstawiciele rządowych instytucji, mających związek z produktami leczniczymi, suplementami diety i wyrobami medycznymi. Swoje stanowisko na jednym z posiedzeń zaprezentowali przedstawiciele branży farmaceutycznej i spożywczej (zob. Raport Zespotu ds. uregulowania reklamy leków, suplementów diety i innych środków spożywczych oraz wyrobów medycznych 1 września 2016 roku). Potrzebę szczególnej kontroli i nadzoru oraz zmian legislacyjnych przedstawiła Najwyższa Izba Kontroli, która opublikowała raport dotyczący suplementów diety (https://www.nik.gov. $\mathrm{pl} /$ aktualnosci/nik-o-dopuszczaniu-do-obrotu-suplementow-diety.html; dostęp: 13.04.2017). Instytut Badań nad Gospodarką Rynkową na zlecenie organizacji branżowych opracował raport, w którym wskazał negatywne skutki, płynące z zakazu reklam dla budżetu państwa, branży farmaceutycznej i konsumentów. Zwrócono uwagę na prawdopodobne zmniejszenie rynku farmaceutycznego, zmniejszenie wpływów z tytułu podatków, wzrost cen leków oraz spadek przeznaczania funduszy na badania kliniczne (zob. IAA Polska). Ostateczna wersja raportu z 1 września 2016 roku zaproponowała większy nadzór nad reklamami ukazującymi się w mediach oraz surowe kary za działania sprzeczne z prawem (zob. DZP więcej niż prawo). Dla gospodarki i pacjentów korzystniejszym rozwiązaniem byłby podatek Garattiniego, ponieważ uzyskany przychód finansowy można byłoby przeznaczyć na pokrycie kosztów wprowadzenia przez polskie apteki opieki farmaceutycznej lub niekomercyjne badania kliniczne proponowane kary finansowe mogą okazać się działaniem krótkookresowym.

\section{Podsumowanie}

W Polsce prawo farmaceutyczne dopuszcza i reguluje aspekty prawne reklamy produktów leczniczych. Jednak brak jest jednoznacznych regulacji prawnych i definicji reklamy odnoszących się do suplementów diety. Stosunkowo łatwo jest też wprowadzić nowy suplement diety na rynek. Wystarczy tylko zgłosić ten fakt do Głównego Inspektora Sanitarnego. Na przestrzeni ostatnich lat rynek leków OTC oraz suplementów diety znacznie zyskał na wartości. Szacuje się, że w 2015 roku jego wartość wyniosła 10,4 mld zł. Przyczynia się do tego wzrost sprzedaży leków OTC i suplementów diety dzięki reklamie w mediach, m.in. telewizji, radiu czy Internecie.

W 2015 roku firmy z sektora farmaceutycznego przeznaczyły na reklamę leków OTC 4,3 mld zł z podziałem na źródła przekazu: w telewizji 2,82 mld zł, a w stacjach radiowych 1,12 mld zł. Producenci suplementów diety w tym 
samym czasie na promocję swoich produktów wydali $871 \mathrm{mln}$ zł. Zwiększona częstotliwość emisji reklam produktów z sektora Zdrowie i Leki jest odnotowywana w okresie jesienno-zimowym oraz wiosennym. Od kilku lat obserwuje się spadek liczby rejestrowanych i przeprowadzanych nowych badań klinicznych, w tym badań nad lekami sierocymi i ratującymi życie lub chorobami rzadkimi. Jednym z rozwiązań jest wprowadzenie podatku Garattiniego od nakładów ponoszonych na reklamę i marketing, z którego przeprowadzane będą niezależne badania kliniczne, szczególnie wspierające badania nad chorobami rzadkimi. W Polsce były propozycje wprowadzenia ustawy refundacyjnej obciążającej 3\% przychodu firmy farmaceutycznej z tytułu objęcia leków refundacją. Ostatecznie jednak nie doszło do realizacji projektu ustawy.

\section{Bibliografia}

Bieńko, P. (2014). Analiza wydatków reklamowych branży farmaceutycznej. Codemedia: https://codemedia.pl/analiza-wydatkow-reklamowych-branzy-farmaceutycznej (dostęp: 19.02.2017).

Booth, B., Zemmel, R. (2004). Prospects for productivity. Nature Reviews Drug Discovery (3).

Cianciara, D., Piotrowicz, M. i Żochowski A. (2013). Społeczno-ekologiczne podejście do telewizyjnej reklamy produktów OTC. Część II: Poziom organizacyjny i polityki. Hygeia Public Health, 48(2).

Dyrektywa Parlamentu Europejskiego i Rady (UE) 2018/1808 z dnia 14 listopada 2018 roku zmieniajaca dyrektywe 2010/13/UE w sprawie koordynacji niektórych przepisów ustawowych, wykonawczych $i$ administracyjnych państw cztonkowskich dotyczacych świadczenia audiowizualnych ustug medialnych (dyrektywa o audiowizualnych ustugach medialnych) ze względu na zmianę sytuacji na rynku. DzUrz. UE L 303; 28.11.2018 PL.

Dyrektywa Parlamentu Europejskiego i Rady 2010/13/UE z dnia 10 marca 2010 roku w sprawie koordynacji niektórych przepisów ustawowych, wykonawczych $i$ administracyjnych państw członkowskich dotyczacych świadczenia audiowizualnych ustug medialnych (dyrektywa o audiowizualnych ustugach medialnych). Dz.Urz. UE L 95;15.04.2010 PL.

DZP więcej niż prawo: https://www.dzp.pl/files/Alerty/pharma_19.html (dostęp: 19.02.2017).

Firma CASE Doradcy, Farmacja nie oszczędza na wydatkach na badania: http://www.rp.pl/ artykul/626792-Farmacja-nie-oszczedza-na-wydatkach-na-badania.html\#ap-1 (dostęp: 19.02.2017).

Gospodarcze skutki wprowadzenia zakazu reklamy leków OTC $i$ suplementów diety (grudzień 2016). Warszawa: Instytut Badań nad Gospodarką Krajową.

GUS (2017). Ochrona zdrowia w gospodarstwach domowych $w 2016 r$. Health care in households in 2016. Warszawa: GUS.

GUS (2014). Ochrona zdrowia $w$ gospodarstwach domowych $w 2013$ r. Warszawa: GUS.

GUS (2018). Trwanie życia w 2017 roku. Warszawa: GUS.

Hermanowski, T., Drozdowska, A. (2012). Opodatkowanie reklamy leków. Farmacja Polska, $68(8)$.

https://www.nik.gov.pl/aktualnosci/nik-o-dopuszczaniu-do-obrotu-suplementow-diety.html, (dostęp: 13.04.2017). 
IAA Polska. Międzynarodowe Stowarzyszenie Reklamy. Prezentacja raportu nt. gospodarczych skutków wprowadzenia zakazu reklamy leków otc i suplementów diety: http://iaa. org.pl/2016/12/19/prezentacja-raportu-nt-gospodarczych-skutkow-wprowadzenia-zakazureklamy-lekow-otc-i-suplementow-diety (dostęp: 19.02.2017).

Informacja o wynikach kontroli. Dopuszczenie do obrotu suplementów diety (2017). Łódź: Delegatura w Łodzi.

Kotler, P., Armstrong, G., Saunders, J. i Wong, V. (2002). Marketing Podręcznik Europejski. Warszawa: Polskie Wydawnictwo Ekonomiczne.

Liberati, A. (2010). Feasibility and challenges of independent research on drugs: the Italian Medicines Agency (AIFA) experience. European Journal of Clinical Investigation, 40(1).

Master Pharm. Opis branży suplementów diety: http://ri.masterpharm.pl/o-spolce/opis-branzy (dostęp: 19.02.2017).

Menedzer Zdrowia 2017, (1).

Mokrysz-Olszyńska, A. (2016). Reklama suplementów diety jako wyzwanie dla ustawodawcy i regulatora. Roczniki Administracji i Prawa, XVI(2).

PMR. Rynek suplementów diety w Polsce. Prognozy na lata 2011-2013 oraz 2015-2020: https://www.pmrpublications.com/product/Rynek-suplementow-diety-Polska-2011; http:// www.marketing-news.pl/message.php?art=44892 (dostęp: 19.02.2017).

Polskie Towarzystwo Studentów Farmacji, Przyszłość Farmaceuty - Badania kliniczne pod lupą: http://ptsf.pl/archiwum/przyszlosc-farmaceuty-badania-kliniczne-lupa (dostęp: 10.02.2019).

PWC (grudzień 2015). Badania kliniczne w Polsce - streszczenie.

Raport „Świadome samoleczenie w Polsce - http://www.lekiczysuplementy.pl 2014” (dostęp: http://zlecone.pap.com.pl/cp/pl/news/info/1621,13,wyniki-najnowszego-badaniaprzeprowadzonego-przez-tns-polska-swiadome-samoleczenie-w-polsce-www-leki;jsessio nid=QT0OkDUkB+b0nwiL+4FTCEVw.undefined (dostęp: 12.02.2019).

Raport PWC (luty 2016). Badania kliniczne w Polsce - obecna sytuacja i perspektywy na przyszłość.

Raport Zespołu ds. uregulowania reklamy leków, suplementów diety i innych środków spożywczych oraz wyrobów medycznych 1 września 2016 roku. Warszawa.

Rozporzadzenie Ministra Zdrowia z dnia 21 listopada 2008 roku w sprawie reklamy produktów leczniczych. DzU z 2008 r., nr 210 poz. 1327.

Sektor farmaceutyczny i biotechnologiczny w Polsce. Warszawa: Polska Agencja Informacji i Inwestycji Zagranicznych S.A.

Sektor Farmaceutyczny stawia na reklamę. Pharmanta Poland: http://pharmanta-poland.com/ sektor-farmaceutyczny-stawia-na-reklame (dostęp: 18.02.2017).

Sfera Biznesu Polska. Raport PMR: Polacy uwielbiaja suplementy diety: http://www.polskatimes.pl/strefa-biznesu/firma/a/raport-pmr-polacy-uwielbiaja-suplementy-diety,10163280 (dostęp: 19.02.2017).

Starzyńska, K. (2015). Charakterystyka reklamy w oparciu o jej geneze $i$ cechy. Uniwersytet Przyrodniczo-Humanistyczny w Siedlcach. Wydział Nauk Ekonomicznych i Prawnych. Zeszyty Naukowe Uniwersytetu Przyrodniczo-Humanistycznego w Siedlcach nr 106. Seria: Administracja $i$ Zarzadzanie (33).

Syrkiewicz-Świtała, M., Holecki, T. i Mazur, M. (2015). Reklama leków OTC jako narzędzie budowania przewagi konkurencyjnej i jej wpływ na zachowania konsumentów na rynku ochrony zdrowia. Sląski Uniwersytet Medyczny w Katowicach. Handel Wewnętrzny, $3(356)$. 
Ulatowska-Szostak, E. (2008). Wpływ reklamy na zakup leków, parafarmaceutyków i preparatów witaminowych w opiniach klientów aptek - porównanie lat 2002 i 2007 . Zakład Higieny Katedry Medycyny Społecznej, Uniwersytet Medyczny im. Karola Marcinkowskiego w Poznaniu. Problemy Higieny i Epidemiologii 2008, 89(3).

Ustawa z dnia 25 sierpnia 2006 roku o bezpieczeństwie żywności i żywienia, art. 3, ust. 3. DzU 2006, nr 171 poz. 1225 ze zm.

Ustawa z dnia 6 września 2001 roku o prawie farmaceutycznym, art. 2. DzU z 2001 r., nr 126, poz. $1381 \mathrm{ze} \mathrm{zm}$.

Ustawa z dnia 6 września 2001 roku o prawie farmaceutycznym, rozdziat 4 reklama produktów leczniczych, art. 52, 53, 57. DzU z 2001 r., nr 126 poz. 1381 ze zm.

Zajdel, W. Przyczyny i skutki wszechobecnej reklamy leków OTC suplementów leków; Rynek Zdrowia, http://www.rynekzdrowia.pl/Farmacja/Przyczyny-i-skutki-wszechobecnej-reklamylekow-OTC-i-suplementow-diety,161335,6.html (dostęp: 18.02.2017). 